André Augusto Mendes Machado

\title{
A InVESTIGAÇÃo CRIMINAL DEFENSIVA
}

\author{
Dissertação de Mestrado \\ Orientação: Prof. Titular Antonio Scarance Fernandes
}

Faculdade de Direito da Universidade de São Paulo

São Paulo

Fevereiro de 2009 
Banca Examinadora: 


\section{ÍNDICE}

I. INTRODUÇÃO 1

II. A INVESTIGAÇÃO CRIMINAL 5

II.1. Conceito e natureza jurídica. 5

II.2. Principais aspectos da investigação criminal ................................................... 8

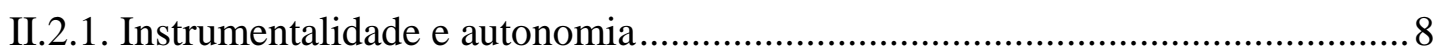

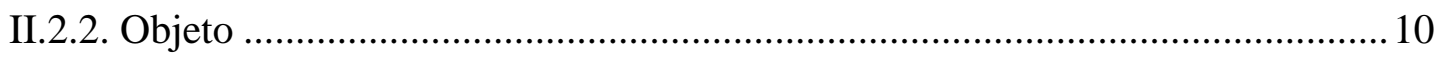

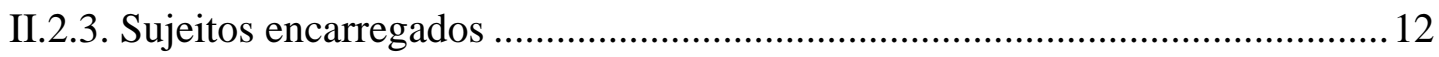

II.2.4. Forma dos atos e sua eficácia probatória....................................................... 15

II.3. Análise histórica da investigação criminal e a sua relação com os modelos de

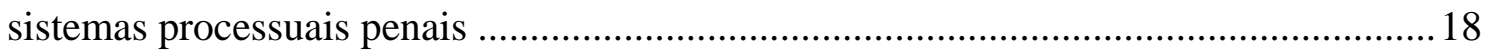

II.4. A investigação pelo Ministério Público ...................................................................24

II.5. A investigação criminal defensiva: delimitação do tema ........................................30

III. O MODELO INVESTIGATÓRIO BRASILEIRO: O INQUÉRITO POLICIAL .........34

III.1. O panorama histórico da investigação criminal no Direito brasileiro......................34

III.2. Conceito e natureza jurídica do inquérito policial. ................................................ 36

III.3. A apuração sumária dos fatos no âmbito do inquérito policial ...............................40

III.4. Eficácia probatória do inquérito policial..............................................................42

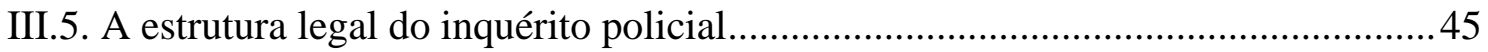

III.6. Os sujeitos envolvidos no inquérito policial ........................................................ 50

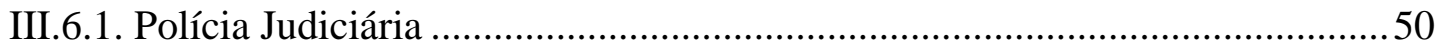

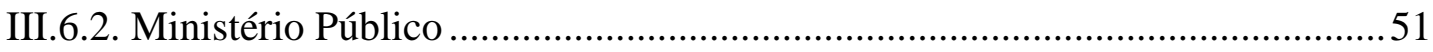


III.6.3. Juiz. 57

III.6.4. Vítima 65

III.6.5. Imputado 69

IV. A INVESTIGAÇÃO CRIMINAL DEFENSIVA COMO GARANTIA DE EQUILÍBRIO ENTRE AS PARTES EM UM PROCESSO PENAL ACUSATÓRIO .......76

IV.1. Apontamentos sobre os princípios constitucionais da igualdade, do contraditório e

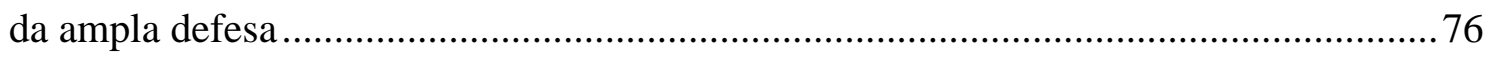

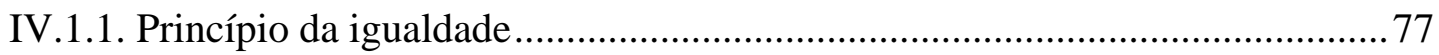

IV.1.2. Princípios do contraditório e da ampla defesa .................................................79

IV.2. O contraditório e o direito de defesa no inquérito policial ..................................84

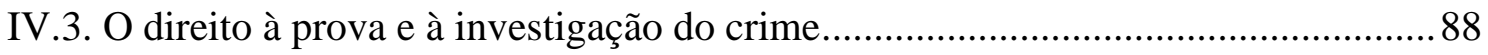

IV.4. A necessidade de investigação criminal defensiva em um sistema processual penal de partes 93

V. A INVESTIGAÇÃO CRIMINAL DEFENSIVA NO DIREITO ESTRANGEIRO ......96

V.1. Preliminarmente: a experiência norte-americana.................................................96

V.1.1. A organização judiciária norte-americana..................................................96

V.1.2. A investigação criminal norte-americana ................................................... 98

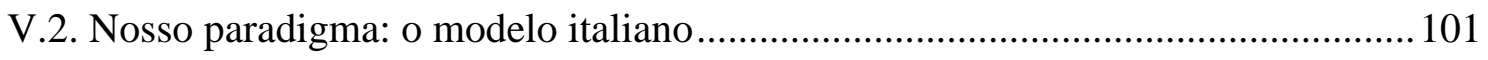

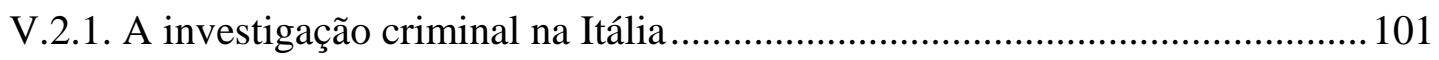

V.2.2. O surgimento da investigação criminal defensiva na Itália........................... 112

V.2.3. O tratamento legislativo da investigação criminal defensiva na Itália .......... 115

V.2.4. Principais temas discutidos na Itália acerca da investigação criminal defensiva 125

VI. A CONCRETIZAÇÃO DA INVESTIGAÇÃO CRIMINAL DEFENSIVA SOB A ÓTICA DA EFICIÊNCIA E DO GARANTISMO ........................................................ 130 
VI.1. O significado de eficiência e garantismo para o processo penal 130

VI.2. O modo de execução da investigação criminal defensiva 132

VI.3. Os limites jurídicos da investigação criminal defensiva. 136

VI.4. A valoração do resultado da investigação criminal defensiva 138

VI.5. A inserção da investigação criminal defensiva no Direito brasileiro 140

VII. CONSIDERAÇÕES FINAIS 145

VIII. APÊNDICE: REFERÊNCIAS À LEGISLAÇÃO ITALIANA 151

IX. BIBLIOGRAFIA 195

X. RESUMO/ABSTRACT 206 


\section{INTRODUÇÃO}

O propósito deste trabalho é analisar a possibilidade de o imputado ${ }^{1}$ realizar diretamente a investigação do crime, por meio de seu defensor, ${ }^{2}$ para reunir os elementos de convicção que lhe sejam favoráveis.

Nos dias de hoje, o interesse pelo tema é crescente, pois representa claro avanço do direito de defesa do imputado ${ }^{3}$ e do modo de apuração da infração penal, além de ser forma de equilibrar o atual movimento no sentido de atribuir poderes investigatórios ao Ministério Público.

Neste estudo, busca-se demonstrar que a investigação criminal defensiva (ou simplesmente investigação defensiva), ${ }^{4}$ apartada daquelas dirigidas por órgãos estatais, é essencial ao processo penal acusatório, por estar está intimamente relacionada com os princípios da igualdade e da ampla defesa.

De fato, esse tipo de investigação garante a indispensável paridade de armas entre a acusação e o imputado, pois permite a obtenção dos meios de prova relevantes para a defesa e que, no momento oportuno, serão utilizados para confrontar os dados materiais reunidos na investigação pública, tendencialmente acusatória. ${ }^{5}$

\footnotetext{
${ }^{1}$ Na obra "Reação Defensiva à Imputação”, Antonio Scarance Fernandes define imputação como “um juízo pelo qual se atribui a alguém a prática de fato penal relevante”. A partir dessa noção, o autor divide a imputação em sentido amplo, que seria aquela existente na fase investigatória e que normalmente se concretiza por meio do indiciamento, e em sentido estrito, que decorreria do oferecimento de acusação formal e instauração da relação jurídico-processual (Reação Defensiva à Imputação. São Paulo: Revista dos Tribunais, 2002, p. 103). Nesse trabalho, utilizaremos o termo "imputado" para indicar o sujeito passivo da instrução preliminar, isto é, aquele sobre o qual recai a imputação em sentido amplo.

${ }^{2} \mathrm{O}$ defensor é a pessoa que, no exercício de atividade profissional, serve à administração da Justiça por meio da proteção exclusiva dos interesses da defesa do imputado ao longo da persecução penal (ROXIN, Claus. Pasado, presente y futuro del derecho procesal penal. Santa Fé: Rubinzal Culzoni, 2007, p. 59). O artigo 133 da Constituição da República prevê a indispensabilidade do advogado para a administração da Justiça e a inviolabilidade dos seus atos e manifestações no exercício da profissão, nos limites da lei.

${ }^{3}$ Como lembra Paolo Tonini: “A noção de 'direito de defesa' compreende não só o direito de defesa contra uma acusação judiciária, mas também o direito de investigar e de produzir as provas que demonstrem os fatos alegados pela parte" ("Direito de defesa e prova científica: novas tendências do processo penal italiano" in Revista Brasileira de Ciências Criminais, n. ${ }^{\circ} 48$, mai.jun. de 2004, p. 195).

${ }^{4}$ Tal denominação será utilizada, ao longo da dissertação, para indicar a investigação criminal realizada pelo imputado, por meio do seu defensor, em contraponto à investigação pública, isto é, aquela conduzida por órgãos estatais (seja a Polícia Judiciária, o Ministério Público ou a Autoridade Judiciária). Cumpre ressalvar, desde logo, que, na Itália, o termo investigação defensiva (investigazioni difensive ou indagini difensive) possui significado mais amplo, incluindo a investigação realizada pelo defensor de qualquer parte privada.

${ }^{5}$ Conforme Luigi Ferrajoli, "para que a disputa se desenvolva lealmente e com paridade de armas, é necessária, por outro lado, a perfeita igualdade entre as partes: em primeiro lugar, que a defesa seja dotada das mesmas capacidades e dos mesmos poderes da acusação; em segundo lugar, que o seu papel contraditor seja admitido em todo o estado e grau do procedimento e em relação a cada ato probatório singular, das
} 
Mais do que isso, a investigação defensiva serve para efetivar os referidos postulados, pois assegura ao imputado, desde o início da persecução penal, a possibilidade de afastar a acusação que lhe foi feita e, dessarte, evitar a instauração de ação penal infundada.

Por outra perspectiva, a investigação defensiva proporciona melhor averiguação dos fatos tidos como criminosos e, com isso, aumenta a eficiência da Justiça Penal. É que ela serve de contrapeso à perquirição realizada pelos entes públicos e amplia o campo cognitivo do Magistrado, fornecendo-lhe dados adicionais àqueles coligidos na investigação pública. Com isso, o Juiz terá melhor suporte material para analisar a imputação formulada e decidir sobre o seu destino.

Não se pode perder de vista que "o objetivo do processo penal não é, e nem pode ser, o de atingir a verdade, mas, sim, o de descobrir qual das percepções trazidas é a que se afigura como a mais plausível, levando-se em conta os fatos postos em julgamento. Nesse sentido, o sistema que promove competições e discussões dialéticas entre várias acepções acerca de um fato é, seguramente, o que melhor poderá refletir a realidade”. ${ }^{6}$

Francisco da Costa Oliveira ${ }^{7}$ enumera os benefícios decorrentes da investigação defensiva, a saber: (i) maior profundidade na investigação das circunstâncias favoráveis ao imputado; (ii) descondicionamento das investigações, normalmente dirigidas no sentido acusatório; (iii) intervenção direta na fixação preliminar do objeto do processo e (iv) maior antecipação das questões fáticas e jurídicas convenientes à defesa.

Não obstante os importantes aspectos relacionados à investigação defensiva, tal matéria é estranha à legislação nacional, que não prevê procedimento investigatório conduzido pelo defensor do imputado, mas tão-somente a possibilidade de se requerer diligência nos autos do inquérito policial.

Tais situações não se confundem. Na investigação defensiva, o defensor dita os rumos do trabalho investigatório, com total autonomia em relação aos entes públicos, de forma a reunir elementos materiais lícitos em favor do imputado. Por sua vez, no inquérito

averiguações judiciárias e das perícias ao interrogatório do imputado, dos reconhecimentos aos testemunhos e às acareações” (Direito e razão: teoria do garantismo penal. São Paulo: Revista dos Tribunais, 2002, p. 490). ${ }^{6}$ ZILLI, Marcos Alexandre Coelho. A iniciativa instrutória do juiz no Processo Penal. São Paulo: Revista dos Tribunais, 2003, p. 50.

${ }^{7}$ A Defesa e a Investigação do Crime. Coimbra: Almedina, 2004, pp. 21/24. 
policial, o defensor não possui o mesmo espaço, uma vez que a direção das investigações cabe à Autoridade Policial, sob a fiscalização do Ministério Público e da Autoridade Judiciária. Admite-se a intervenção do imputado, em atenção ao direito de defesa, mas "não se trata de defesa ampla, mas limitada ao resguardo dos interesses mais relevantes do suspeito, como o requerimento de diligências, o pedido de liberdade provisória, de relaxamento de flagrante, a impetração de habeas corpus”. 8

Nota-se a relevância do tema em comento a justificar o seu estudo crítico, pois, além de reforçar direitos fundamentais do imputado e de incrementar a eficiência da Justiça Penal, é assunto inédito no ordenamento jurídico brasileiro e pouco discutido pela doutrina pátria.

Sendo assim, de início, são examinados os principais aspectos da investigação criminal, com o objetivo de compreender o seu papel dentro da persecução penal. Assim, cuida-se da sua definição e natureza jurídica, características principais e contextualização histórica. Destaca-se, em tópico específico, a investigação pelo Ministério Público, por ser o procedimento em voga para a apuração de infrações penais e que vem se disseminando mundo afora. Ao cabo deste capítulo, coloca-se, em linhas gerais, o tema da investigação defensiva, revelando a sua imprescindibilidade nos sistemas jurídicos que adotam a investigação ministerial.

O inquérito policial, principal modelo de investigação criminal positivado no Brasil, é objeto de capítulo próprio, em que, além da origem histórica, são apontados os aspectos formais e substanciais mais relevantes deste procedimento.

No quarto capítulo, desenvolve-se a idéia da investigação defensiva como instrumento para garantir o equilíbrio entre as partes em um processo penal acusatório, pois assegura a isonomia entre os sujeitos envolvidos na persecução penal e reforça o direito de defesa do imputado. Para tanto, são conceituados, preliminarmente, os princípios da igualdade, do contraditório e da ampla defesa, mencionando-se o debate existente sobre a incidência desses dois últimos no inquérito policial. Em seguida, ocupa-se dos direitos à prova e à investigação, pressupostos para o desenvolvimento da investigação defensiva.

\footnotetext{
8 SCARANCE FERNANDES, Antonio. Processo Penal Constitucional. $3^{\mathrm{a}}$ ed.. São Paulo: Revista dos Tribunais, 2002, pp. 64/65.
} 
O quinto capítulo, por sua vez, refere-se ao tratamento dado à investigação defensiva na Itália, onde o assunto é bastante discutido, em razão da sua recente incorporação na legislação processual penal. Da legislação e doutrina desse país, extraemse noções essenciais à compreensão do tema em lume. Aborda-se, ainda, a investigação defensiva nos Estados Unidos da América, mais a título ilustrativo do que com a pretensão de analisar todas as suas nuances, porque se trata de ordenamento jurídico assentado em bases totalmente diversas do brasileiro.

O trabalho é finalizado com o estudo da investigação defensiva, sob a ótica da eficiência e do garantismo. Nesse passo, procura-se esclarecer o sentido deste binômio para o processo penal e relacioná-lo com os principais aspectos procedimentais da investigação defensiva: o modo de execução, os limites jurídicos e a valoração do resultado da investigação defensiva. Ao final, cuida-se da incorporação da investigação defensiva ao ordenamento jurídico pátrio. 


\section{A INVESTIGAÇÃO CRIMINAL}

\section{II.1. Conceito e natureza jurídica}

A persecução penal, ou persecutio criminis, enquanto "atividade estatal de proteção penal”, ${ }^{9}$ abrange dois momentos distintos: o da investigação e o da ação penal.

O termo “investigação” deriva dos vocábulos latinos investigatio e investigare, que significam indagar com cuidado, seguir o rastro, perscrutar. Entende-se por investigação, no sentido gramatical, a pesquisa de vestígios e indícios relativos a certos fatos para esclarecer ou descobrir alguma coisa. ${ }^{10}$

Juridicamente, a investigação é um procedimento ${ }^{11}$ formado por um conjunto de atos interligados que visam a elucidar um fato obscuro. Quando a circunstância a ser aclarada é uma possível prática delituosa, qualifica-se a investigação de “criminal”.

José Frederico Marques ${ }^{12}$ define a investigação criminal como atividade estatal de persecução criminal destinada a preparar a ação penal, que apresenta caráter preparatório e informativo, pois o seu objetivo é levar ao órgão encarregado da ação penal os elementos necessários para a dedução da pretensão punitiva em juízo.

O autor destaca o caráter informativo da investigação, o que, em sua opinião, seria uma das principais diferenças em relação à instrução existente na ação penal: a primeira teria por escopo obter dados informativos para o órgão acusatório examinar a viabilidade de propositura da ação penal; enquanto o objeto da segunda seria colher provas para demonstrar a legitimidade da pretensão punitiva ou do direito de defesa. ${ }^{13}$

\footnotetext{
${ }^{9}$ Conceito de Ernst Belling, citado por José Frederico Marques (Elementos de Direito Processual Penal. Campinas: Bookseller, 1997, vol. I, p. 127).

${ }^{10}$ SILVA, De Plácido e. Vocabulário Jurídico. 15ª ed.. Rio de Janeiro: Forense, 1998, p. 451.

${ }^{11}$ Segundo Antonio Scarance Fernandes, "o procedimento apresenta a característica de ser composto de atos ordenados de forma metódica, de maneira que um pressupõe o próximo até o último ato da série, distinguindo-se, por isso, de outras realidades de formação sucessiva. A idéia de ordem insere-se no contexto da realidade unitária procedimental e a explica" (Teoria Geral do Procedimento e o Procedimento no Processo Penal. São Paulo: Revista dos Tribunais, 2005, p. 33).

${ }^{12}$ Elementos..., p. 139.

${ }^{13}$ Ibid., p. 139.
} 
Justamente por conta desta suposta qualidade informativa da persecução prévia defendeu-se a ausência do direito de defesa nessa fase - o que encontrou ressonância na doutrina nacional da época.

Poucas vozes divergentes foram ouvidas, com destaque para Joaquim Canuto Mendes de Almeida, ${ }^{14}$ que propugnou a existência de atos instrutórios (repetíveis e irrepetíveis) na investigação, por ele denominada de “instrução preliminar”. Estes atos teriam função preparatória e preservadora, possuindo certa carga decisória, pois embasariam o juízo de acusação e as medidas cautelares pessoais e patrimoniais ultimadas nessa fase. Com isso, haveria a necessidade de se atribuir, desde já, direito de defesa ao imputado.

Tais atos instrutórios seriam diferentes dos atos de investigação, que não teriam por função formar o convencimento judicial, sendo praticados pela Autoridade Policial, logo após tomar conhecimento de possível ação delituosa, para acautelar os meios de prova.

Mais recentemente, argumentou Marta Saad ${ }^{15}$ que os elementos constantes da investigação preliminar não teriam finalidade apenas informativa, mas também amparariam o convencimento a respeito da viabilidade da ação penal, ou sobre as condições necessárias para a decretação de qualquer provimento cautelar no curso da fase investigatória.

Sem embargo dessa discussão doutrinária a respeito do caráter informativo da investigação criminal - à qual se retornará oportunamente -, é possível defini-la como o “conjunto de atividades realizadas concatenadamente por órgãos do Estado, a partir de uma notícia-crime ou atividade de ofício; com caráter prévio e de natureza preparatória com relação ao processo penal; que pretende averiguar a autoria e as circunstâncias de um fato

\footnotetext{
${ }^{14}$ ALMEIDA, Joaquim Canuto Mendes de. Princípios fundamentais do processo penal. São Paulo: Revista dos Tribunais, 1973, pp. 07/10. Assevera o autor que "instrução criminal é atividade de informar-se a autoridade sobre a infração, com todas as suas circunstâncias. Dela depende a imposição da pena ou a aplicação da medida de segurança, em seus aspectos positivos (condenação) e negativos (absolvição), e, então, se denomina instrução definitiva. Entretanto, dela depende, também, liminarmente, a sujeição ou não do indiciado à acusação e, nesse caso, se chama instrução provisória ou preliminar ou, ainda, curtamente, instrução criminal, em sentido estrito" (Ibid, pp. 191/92). No mesmo sentido: PITOMBO, Sérgio Marcos de Moraes. Inquérito policial: novas tendências. Belém: CEJUP, 1987, p. 22; e PIMENTEL, Manoel Pedro. Advocacia Criminal: teoria e prática. São Paulo: Revista dos Tribunais, 1965, p. 17.

${ }^{15}$ O direito de defesa no inquérito policial. São Paulo: Revista dos Tribunais, 2004, p. 160.
} 
aparentemente delitivo, com o fim de justificar o exercício da ação penal ou o arquivamento (não processo)”. ${ }^{16}$

Tal conceito traz os elementos essenciais da investigação criminal. Peca apenas ao afirmar que a investigação criminal seria necessariamente efetuada por órgãos estatais. Melhor seria se a definição fosse mais ampla e incluísse também o defensor do imputado, da vítima e de outras partes privadas, como possíveis encarregados da investigação.

Nesse passo, pode-se conceituar a investigação criminal como procedimento preliminar e preparatório à ação penal, formado por um conjunto de atos encadeados, que podem ser praticados pelos sujeitos envolvidos e diretamente interessados na persecução penal, com a finalidade de reunir elementos materiais relacionados ao possível ilícito penal.

Ao contrário do aduzido por alguns autores, a investigação criminal não busca comprovar a infração penal. O seu objetivo não é confirmar a tese acusatória, mas verificar a plausibilidade da imputação, evitando processos criminais desnecessários. ${ }^{17}$

A investigação criminal possui natureza jurídica complexa, pois é composta por atos administrativos, judiciais e até jurisdicionais. Dessarte, a natureza jurídica de determinada modalidade de investigação criminal depende da natureza jurídica dos atos predominantes.

Nessa ordem de idéias, a investigação criminal pode ser um procedimento judicial ou administrativo, caso o órgão encarregado pela investigação pertença ou não ao Poder Judiciário, respectivamente. Na primeira hipótese, enquadram-se os sistemas de juizado de instrução, conduzidos por Autoridade Judiciária cujos atos, naturalmente, são judiciais. Na segunda, ajustam-se as investigações a cargo da Polícia Judiciária, que pratica atos de caráter administrativo.

Esta qualificação da instrução prévia como judicial ou administrativa leva em consideração apenas o aspecto formal do órgão responsável pela investigação. Caso se atente para a finalidade dos atos desenvolvidos nessa fase, que visam à preliminar

\footnotetext{
${ }^{16}$ LOPES Jr., Aury. Sistemas de investigação preliminar no Processo Penal. $3^{\mathrm{a}}$ ed.. Rio de Janeiro: Lumen Juris, 2005, p. 36.

${ }^{17}$ Conforme escólio de Francesco Carnelutti, a investigação não se faz para comprovar um delito, mas para excluir uma imputação aventurada (Direito Processual Penal. Campinas: Peritas, 2001, v. 2, p. 113).
} 
formação de culpa, mesmo a investigação conduzida pela Polícia Judiciária pode ser vista como procedimento judicial. ${ }^{18}$

Ademais, a investigação criminal sempre terá natureza pré-processual, por ser prévia ao processo, com o escopo de fundamentar a sua instauração ou, em caso de imputações infundadas, evitá-la. Nesse momento, não há, ainda, o exercício de pretensão acusatória e nem se pode falar em partes stricto sensu, pois inexiste uma estrutura processual dialética, sob a garantia do contraditório e o controle da Autoridade Judiciária. ${ }^{19}$

A respeito do caráter pré-processual da investigação criminal, salienta Antonio Scarance Fernandes ${ }^{20}$ que, antes da fase processual, pode ser necessário o transcurso de fase prévia destinada à investigação, que não faz parte do processo, mas o prepara.

Sendo assim, conclui-se que a investigação criminal é um procedimento administrativo ou judicial - conforme o órgão responsável por sua condução - e préprocessual, pois ocorre antes do processo criminal, para reunir elementos de convicção acerca de possível infração penal.

\section{II.2. Principais aspectos da investigação criminal}

\section{II.2.1. Instrumentalidade e autonomia}

A persecução prévia apresenta duas notas características que merecem destaque: instrumentalidade e autonomia. Em primeiro lugar, é um procedimento instrumental à ação penal, pois se destina a esclarecer os fatos constantes da notícia de crime, fornecendo subsídios para o prosseguimento ou o arquivamento da persecução penal.

Ressalta Aury Lopes Jr. ${ }^{21}$ que a instrumentalidade da investigação preliminar pode ser qualificada como de segundo grau, por ser instrumento a serviço de outro

\footnotetext{
${ }^{18}$ PITOMBO, Sérgio Marcos de Moraes, Inquérito..., pp. 21/22.

${ }^{19}$ LOPES Jr., Aury, Sistemas..., pp. 39/40.

${ }^{20}$ Teoria Geral..., p. 35.

${ }^{21}$ Sistemas..., p. 10.
} 
instrumento, o processo criminal, que, por seu turno, destina-se à aplicação da norma penal em respeito aos direitos e garantias individuais.

Do caráter instrumental da investigação criminal infere-se a sua dupla função assinalada pela doutrina pátria, a saber: (i) preservadora e (ii) preparatória. Preservadora, porque inibe a instauração de ação penal infundada e, com isso, resguarda a liberdade do inocente e evita custos desnecessários para o Estado. ${ }^{22}$ Preparatória, porque acautela meios de prova que poderiam desaparecer com o decurso do tempo.

Em melhores palavras, resume Joaquim Canuto Mendes de Almeida: “Estabelecemos que a função preparatória da instrução preliminar se determina pela necessidade de produção, antes e fora da audiência, de provas dificilmente realizáveis no tempo e no local de concentração do processo. Vimos, mais, que a função preventiva decorre da necessidade de fundamentar um juízo de acusação, isto é, um julgamento prévio dos elementos acusatórios, quer para garantia da inocência contra a leviandade ou calúnia, quer para garantia do organismo jurisdicional contra os dispêndios inúteis e injustos de tempo e de trabalho". ${ }^{23}$

Em segundo lugar, a investigação criminal é marcada pela autonomia, pois, apesar de servir ao processo, sua existência não depende deste. Há casos em que a imputação é descabida e a investigação arquivada sem se iniciar a relação jurídica processual. Por outro lado, pode haver processo sem prévia instrução preliminar, se o órgão acusatório possuir dados suficientes da autoria e materialidade delitiva para apresentar, desde logo, acusação formal.

Ensina Aury Lopes $\mathrm{Jr}^{24}$ que a autonomia da investigação criminal reflete-se em seus três planos: sujeito, objeto e atos. No tocante aos sujeitos, aqueles que intervêm na instrução preliminar não são, normalmente, os mesmos que atuam no processo e, ainda que sejam, o conteúdo da intervenção é totalmente diferente. Quanto ao objeto, na investigação apura-se, em grau limitado de cognição, o fato constante da notícia de crime; já o processo cuida da pretensão acusatória e sua resistência por parte do imputado. Por fim, as

\footnotetext{
${ }^{22}$ Segundo Aury Lopes Jr., a investigação criminal apóia-se em três pilares básicos: esclarecer o fato oculto, salvaguardar a sociedade e obstar acusações infundadas. Este último ponto constituiria o principal fundamento da instrução preliminar, que funcionaria como verdadeiro "filtro processual", evitando ações penais sem o indispensável arrimo fático e jurídico (Sistemas..., pp. 45/52).

${ }^{23}$ Princípios..., p. 30. No mesmo sentido: SAAD, Marta, O direito de defesa..., pp. 23/25 e 131/32.

${ }^{24}$ Sistemas..., p. 41.
} 
diferenças apontadas nos planos anteriores acabam por distinguir os atos praticados no processo daqueles perpetrados na investigação, nos quais há uma limitação do contraditório e da defesa, bem como o predomínio da forma escrita e do segredo.

Após verificar as principais peculiaridades da investigação criminal, importa melhor delimitar o seu conteúdo, extensão e forma de efetivação.

\section{II.2.2. Objeto}

A investigação criminal tem por finalidade averiguar as circunstâncias relatadas na notícia de crime, coligindo elementos relacionados à alegada prática delitiva. Como salientado por Claus Roxin, ${ }^{25}$ a instrução preliminar deve estruturar-se de forma a possibilitar não somente a comprovação de culpabilidade do imputado, mas também a exoneração do inocente.

Nessa fase investigatória, não há acusação em sentido estrito, uma vez que o seu escopo é justamente verificar a viabilidade de eventual pretensão acusatória. A investigação é que permitirá “a transição entre a mera possibilidade (notícia-crime) para uma situação de verossimilitude (imputação/indiciamento) e posterior probabilidade (indícios racionais), necessária para adoção de medidas cautelares e para receber a ação penal”. ${ }^{26}$

Conforme o clássico magistério de Francesco Carnelutti, ${ }^{27}$ o juízo de possibilidade é aquele em que as razões favoráveis ou contrárias à hipótese são equivalentes. Tal juízo é suficiente para a instauração de procedimento investigatório, mas não para se iniciar a ação penal. Esta depende de juízo de probabilidade, isto é, o predomínio das razões positivas a respeito da ocorrência de uma infração penal.

\footnotetext{
${ }^{25}$ Pasado, presente y futuro..., p. 152.

${ }^{26}$ LOPES Jr., Aury, Sistemas..., p. 41.

${ }^{27}$ Lecciones sobre el Proceso Penal. Trad. Santiago Sentis Melendo. Buenos Aires: Bosch, 1950, vol. II, pp. $181 / 182$.
} 
Sérgio Marcos de Moraes Pitombo ${ }^{28}$ menciona que o juízo de possibilidade seria neutral, pois faltariam motivos fortes pró ou contra a acusação; ao passo que o juízo de probabilidade seria aneutral, partindo de razões robustas, porém ainda não decisivas, que seriam suficientes apenas para imputar.

O objeto da investigação criminal, portanto, é a tarefa de reunir elementos materiais capazes de precisar o nível do juízo existente acerca dos fatos narrados na notícia de crime. Se permanecer o juízo de possibilidade, o investigatório deve ser arquivado. Caso se evolua para o juízo de probabilidade, inicia-se a ação penal.

Por outro lado, a investigação não pode se aprofundar a ponto de pretender formar juízo de certeza sobre a imputação - o que somente ocorre no momento da prolação da sentença, após a instrução processual.

A partir disso, deduz-se que a investigação criminal é uma fase de cognição sumária, ou seja, a atividade instrutória está limitada à obtenção dos elementos indispensáveis para a comprovação do fumus commissi delicti, sob pena de retardar indefinidamente a apuração dos fatos e levar à posterior repetição de atos probatórios prematuramente realizados na investigação. ${ }^{29}$

A sumariedade da instrução preliminar implica limitações de natureza qualitativa e quantitativa. A primeira restringe a matéria a ser apreciada durante a investigação e o seu respectivo grau de convencimento por parte do titular da investigação. ${ }^{30}$

Já a limitação quantitativa diz respeito ao aspecto temporal, estabelecendo um prazo determinado para o fim da investigação criminal. Para a adequação desse lapso

\footnotetext{
${ }^{28}$ Inquérito..., pp. 38/39. O juízo provável é o que autoriza o indiciamento do sujeito passivo da investigação preliminar (PITOMBO, Sérgio Marcos de Moraes. "O indiciamento como ato de Polícia Judiciária" in Revista dos Tribunais, n. ${ }^{\circ}$ 577, novembro de 1983, p. 314).

${ }^{29}$ LOPES Jr., Aury, Sistemas..., pp. 101/104.

${ }^{30}$ A limitação qualitativa divide-se nos planos horizontal e vertical. Leciona Aury Lopes Jr. que "a cognitio está limitada no plano horizontal pela impossibilidade de que sejam comprovadas com plenitude a existência do fato e a sua autoria" e "também está limitado no plano vertical, pois o titular da investigação preliminar deverá contentar-se com um juízo superficial acerca da tipicidade, da ilicitude e da culpabilidade do fato do autor” (Ibid., p. 105).
} 
temporal, é importante considerar a complexidade dos fatos, a gravidade do delito e a sujeição do imputado à prisão cautelar. ${ }^{31}$

É comum os ordenamentos jurídicos conciliarem as limitações qualitativa e quantitativa, criando um sistema misto. É o caso, por exemplo, do Brasil, que prevê para o inquérito policial, em tese, restrição material no artigo $4^{\circ}$, caput, do Código de Processo Penal, e temporal no artigo 10 do mesmo Estatuto. ${ }^{32}$ Caso a investigação criminal extrapole as referidas limitações, deve ser reconhecida a ineficácia dos seus atos, tal como sucede na Itália. $^{33}$

\section{II.2.3. Sujeitos encarregados}

Note-se, de saída, que a atividade de investigação criminal não é exclusividade de órgãos estatais. Eventualmente, os elementos de convicção podem ser obtidos por um particular (v.g. o defensor do imputado, do ofendido ou de qualquer outra parte privada), fora dos autos de um procedimento administrativo conduzido por autoridade pública - é o que se denomina investigação privada. ${ }^{34}$

Segundo Bruno Calabrich, ${ }^{35}$ o que diferencia as investigações estatais das privadas é, basicamente, a ausência de imperatividade, ou seja, de poder de coerção destas

\footnotetext{
${ }^{31}$ Ibid., p. 106.

${ }^{32}$ Segundo o artigo $4^{\circ}$, caput, do Código de Processo Penal, a investigação feita pela Polícia Judiciária “terá por fim a apuração das infrações penais e da sua autoria”. Por sua vez, o artigo 10 do Código de Processo Penal estabelece o prazo de 10 (dez) dias para o término do inquérito policial, se o indiciado estiver preso preventivamente, e de 30 (trinta) dias se estiver solto.

${ }^{33} \mathrm{O}$ artigo 407, 3, do Código de Processo Penal italiano, prescreve a pena de "inutilizzabilità". Reza tal dispositivo que "qualora il pubblico ministero non abbia esercitato l’azione penale o richiesto l’archiviazione nel termine stabilito dalla legge o prorogato dal giudice, gli atti di indagine compiuti dopo la scadenza del termine non possono essere utilizzati”.

${ }^{34}$ Importante não confundir a investigação privada realizada pelo defensor, sem regulamentação no Brasil, com a atividade de investigador particular. Tal ofício, no Brasil, foi instituído pela Lei n. ${ }^{0}$ 3.099, de 24 de fevereiro de 1957, e regulamentado pelo Decreto n. ${ }^{\circ}$ 50.532, de 03 de maio de 1961. Permite-se o trabalho de investigador particular, desde que não invada a competência privativa da Polícia Judiciária, nem atente contra a inviolabilidade domiciliar, a vida privada e a boa fama das pessoas.

${ }^{35}$ Investigação criminal pelo Ministério Público: fundamentos e limites constitucionais. São Paulo: Revista dos Tribunais, 2007, pp. 69/70. O autor cita, ainda, a obrigatoriedade da investigação estatal em confronto com a facultatividade da investigação privada, verbis: “Outra característica digna de nota é a obrigatoriedade da investigação estatal (praticado o crime, é dever do Estado investigá-lo, se necessário), que se confronta com a facultatividade da investigação pelo particular (os custos - financeiros, sociais, emocionais etc. - de uma investigação podem demover o particular da intenção de realizá-la diretamente, ainda que seja de seu interesse e tenha este particular pouca esperança na eficiência de uma investigação estatal)” (Ibid., p. 70).
} 
últimas. Assim, quando o particular investiga por conta própria, conta apenas com seus esforços pessoais e com a colaboração de outras pessoas e de entes públicos ou privados.

Considerando este critério subjetivo do responsável pela atividade investigatória, a investigação defensiva, tanto quanto aquela realizada pela vítima ou qualquer outro particular, é espécie de investigação privada. Isso porque nenhuma delas é efetuada por ente estatal. Por conseguinte, a investigação defensiva deve obedecer às limitações impostas a todo tipo de investigação privada, principalmente devido à falta de poder de polícia, como se verificará adiante.

Já a investigação criminal ultimada por órgãos estatais, que denominamos investigação pública, será atribuída, conforme o caso, à Polícia Judiciária, ao Juiz de Direito ou ao Ministério Público.

Na primeira hipótese, presente no Brasil e na Inglaterra, incumbe à Autoridade Policial definir a linha de investigação, praticando diretamente os atos pertinentes ao esclarecimento da imputação, exceto aqueles que impliquem restrição a direitos fundamentais, por dependerem de prévia autorização judicial.

Nesse tipo de investigação, a Autoridade Policial tem autonomia para estabelecer os meios e a forma de investigação, sem subordinação funcional ao Ministério Público e aos Juízes, que podem apenas fiscalizar as atividades policiais. ${ }^{36}$

Existe, ainda, a possibilidade de a investigação ser conduzida pela Autoridade Judiciária, o denominado "Juiz instrutor”, como ocorre na França ${ }^{37}$ e na Espanha. Ao tomar conhecimento da imputação, o Magistrado determina a instauração do procedimento

\footnotetext{
${ }^{36}$ Para Aury Lopes Jr., a investigação policial apresenta poucas vantagens, salientando a amplitude da presença policial, a suposta celeridade e a economia para o Estado. Em contrapartida, o autor afirma que esse modelo está totalmente superado e contém inúmeras desvantagens, assim sintetizadas: (i) alta discricionariedade de fato na seleção das condutas a serem perseguidas; (ii) variação da eficácia da atuação policial conforme a gravidade do delito, a atitude do denunciante, a atitude do imputado e sua condição econômica e social; (iii) restrição dos direitos e garantias individuais do imputado; (iv) suscetibilidade à influência política e da mídia; (v) descrédito probatório do material recolhido, que não prestará para formar a opinio delicti do órgão acusatório (Sistemas..., pp. 65/69). Marta Saad resume as principais críticas feitas ao inquérito policial: (i) morosidade; (ii) oneroso e levaria à repetição desnecessária de provas em juízo; (iii) impossibilidade de defesa do imputado; (iv) abusos cometidos no interior dos Distritos Policiais; (v) incapacidade de apurar determinados tipos de infrações penais, como crimes contra a administração pública e de colarinho branco ( $O$ direito de defesa..., p. 188).

37 O Poder Legislativo francês aprovou, recentemente, a substituição do juizado de instrução pela investigação ministerial. Aguarda-se apenas a sanção do Presidente da República para a instituição da investigação ministerial na França.
} 
investigatório e desenvolve os atos necessários à elucidação do fato constante da notícia de crime.

A iniciativa investigatória é de responsabilidade do Juiz instrutor, que pode atuar diretamente ou com o auxílio da Polícia Judiciária. Em regra, permite-se a solicitação de diligências pelo Ministério Público e pelo defensor, que são efetuadas a critério do Juiz instrutor.

Vale ressaltar que o atual Juiz instrutor não se confunde com a antiga figura do “inquisidor”. Primeiro, porque há a separação das funções de investigar, acusar e julgar: enquanto o Juiz instrutor investiga, o Ministério Público ou o próprio ofendido acusam e um outro Juiz - diverso do instrutor - atua no processo. Segundo, porque o Juiz instrutor, ao contrário do inquisidor, tem o dever de ser imparcial, recolhendo provas relacionadas à imputação, independentemente de serem favoráveis à acusação ou ao imputado. ${ }^{38}$

Por fim, o Ministério Público, por meio da figura do "Promotor investigador", pode ser o responsável pela investigação criminal. É o modelo vigente na Itália, Portugal, Alemanha e nos países latino-americanos que seguiram o Código de Processo Penal Modelo para a Ibero-América.

Nesse sistema, o Promotor, ciente de um suposto delito, realiza sponte propria ou com auxílio da Polícia Judiciária as diligências necessárias para a apuração do fumus commissi delicti.

\footnotetext{
${ }^{38}$ LOPES Jr., Sistemas..., pp. 71/73. Segundo Aury Lopes Jr., a investigação judicial possui a vantagem de ser dirigida por um órgão suprapartes, que atua com imparcialidade e independência, assegurando melhor qualidade do acervo probatório. Como inconvenientes da instrução preliminar judicial, o autor evidencia a forma inquisitória do modelo, decorrente do fato de o Juiz instrutor ser o responsável pelo recolhimento da prova. Com isso, um mesmo órgão decide sobre a necessidade de um ato de investigação e examina a sua legalidade, o que afeta as garantias fundamentais do imputado. Para este jurista, o traço distintivo entre os sistemas acusatório e inquisitório não é a mera separação das funções de acusar e julgar, mas a gestão da prova. Por tal motivo, os sistemas de investigação judicial existentes, hoje em dia, seriam tipicamente inquisitórios, apesar de haver separação entre investigação (Juiz instrutor), acusação (Ministério Público ou ofendido) e julgamento (Juiz da causa). Além disso, levanta os seguintes problemas: (i) morosidade, pois o Juiz instrutor tende a converter a instrução preliminar em definitiva, retardando injustificadamente o andamento do feito; (ii) contradição lógica inerente ao fato de o Juiz investigar e outro órgão acusar, o qual, muitas vezes, não está de acordo com a linha de investigação judicial; e (iii) utilização das provas produzidas na investigação em sede processual, sendo meramente ratificadas na fase instrutória e valoradas na sentença (Ibid., pp. 82/84). Marta Saad menciona que, nos países em que foi implementado, o juizado de instrução sofre as mesmas críticas que aqui são feitas ao inquérito policial, em especial a necessidade de repetição dos atos probatórios e a falta de participação da defesa (O direito de defesa..., p. 189).
} 
Do mesmo modo que a Autoridade Policial, o Promotor investigador depende de autorização judicial para ultimar medidas restritivas de direitos fundamentais. Em regra, nos ordenamentos em que a investigação é dirigida pelo Ministério Público, existe um Juiz responsável especificamente pela instrução preliminar (Juiz de garantias), que tem a função de zelar pelos direitos e garantias individuais, bem como controlar a legalidade dos atos praticados pelo Promotor investigador.

A investigação ministerial será examinada, com maior profundidade, em tópico específico, por ser o modelo em voga hodiernamente.

\section{II.2.4. Forma dos atos e sua eficácia probatória}

Formalmente, a persecução prévia pode ser escrita ou oral; obrigatória, facultativa ou mista e pública ou secreta. Será escrita se a maioria dos atos praticados nessa fase for registrada em documento escrito, os quais serão considerados na formação do juízo das autoridades competentes. Ao contrário, será oral se houver o predomínio de atos produzidos oralmente, que servirão de base para a resolução judicial. ${ }^{39}$

Além disso, a investigação criminal classifica-se em obrigatória, facultativa ou mista, conforme a sua realização seja indispensável ou não para o exercício da ação penal. Se for facultativa, pode ser apresentada acusação formal, com esteio nos elementos probatórios já existentes, independentemente de persecução prévia. ${ }^{40}$ Se for obrigatória, a

\footnotetext{
${ }^{39}$ Assinala Aury Lopes Jr. que a oralidade, ao contrário da forma escrita, está normalmente vinculada à publicidade, imediação, concentração dos atos e identificação física do Juiz. A partir dessa constatação, o autor afirma que a classificação de um sistema de investigação preliminar como oral ou escrito dependerá do órgão encarregado da persecução e da estrutura da fase intermediária, que é o momento em que se aprecia a admissibilidade de eventual acusação. Nesse passo, o sistema de investigação preliminar judicial é marcado por uma maior oralidade, imediação, concentração de atos e identidade física do Juiz, pois a Autoridade Judiciária conduz a investigação e decide sobre a sua viabilidade. Por outro lado, na investigação ministerial ou policial, um ente é o titular da investigação e outro decide sobre a instauração do processo com base na análise das provas levantadas (normalmente registradas em forma escrita). Por conseguinte, predomina a forma escrita, ausência de imediação e concentração de atos e não há a preocupação com a identidade física do Juiz (Sistemas..., pp. 115/116).

${ }^{40}$ É o sistema adotado no Brasil, em que o Ministério Público ou o ofendido poderão acusar, sem prévia investigação policial, caso tenham provas suficientes da materialidade e autoria delitivas. A esse respeito, confiram-se os seguintes dispositivos: artigo 39, §5º do Código de Processo Penal: "o órgão do Ministério Público dispensará o inquérito, se com a representação forem oferecidos elementos que o habilitem a promover a ação penal, e, neste caso, oferecerá a denúncia no prazo de 15 (quinze) dias”; e artigo 40 do Código de Processo Penal: "quando, em autos ou papéis de que conhecerem, os juízes ou tribunais verificarem a existência de crime de ação pública, remeterão ao Ministério Público as cópias e os documentos necessários ao oferecimento da denúncia”.
} 
abertura de processo criminal está condicionada ao resultado da instrução preliminar. Há, ainda, o sistema misto, no qual a investigação é obrigatória para os delitos graves e facultativa para os crimes de menor lesividade e complexidade.

Ademais, a persecução prévia pode ser pública ou secreta, conforme se limite ou não o acesso de terceiros - e, às vezes, do próprio imputado - aos atos investigatórios. A maioria dos ordenamentos jurídicos atuais prevê a publicidade como regra, admitindo o sigilo em casos excepcionais para garantir a intimidade e a privacidade do imputado ou a eficácia de certas diligências investigatórias. ${ }^{41}$

A publicidade será plena se qualquer pessoa tiver acesso ao investigatório ou parcial se apenas as partes puderem ter ciência dos autos. No primeiro caso, inexiste qualquer tipo de sigilo, já no segundo há o sigilo externo, pois terceiros, alheios aos fatos apurados, não terão acesso aos atos de investigação. ${ }^{42}$

É possível que o conhecimento dos atos investigatórios seja restringido até mesmo para alguns sujeitos processuais, em regra o imputado, o que se denomina sigilo interno. Esse tipo de sigilo visa a assegurar a eficiência da investigação, que poderia restar prejudicada com a ciência prévia de determinadas diligências pelo imputado. ${ }^{43}$

Além dos sobreditos aspectos formais, cumpre observar que os atos de investigação têm eficácia probatória limitada, servindo tão-somente para fundamentar as decisões interlocutórias proferidas ao longo da instrução preliminar, bem como justificar eventual ação penal ou o arquivamento do feito.

\footnotetext{
${ }^{41} \mathrm{O}$ artigo $5^{\circ}$, LX, da Constituição da República, consagra a publicidade dos atos processuais, admitindo a sua restrição apenas em defesa da intimidade ou do interesse social. O artigo 37, caput, da Carta Magna, coloca a publicidade como princípio norteador de toda a Administração Pública e, por conseguinte, do Poder Judiciário. Além disso, o artigo 93, IX, da Constituição da República, declara que serão públicos todos os julgamentos dos órgãos do Poder Judiciário, "podendo a lei limitar a presença, em determinados atos, às próprias partes e a seus advogados, ou somente a estes, em casos nos quais a preservação do direito à intimidade do interessado no sigilo não prejudique o interesse público à informação”.

${ }^{42}$ Note-se que sigilo e segredo não se confundem, guardando entre si relação de continente e conteúdo. O segredo é a qualidade confidencial de uma informação, isto é, aquilo que não pode ser revelado a terceiros, por versar sobre assunto de foro íntimo. Segundo a teoria dos círculos concêntricos da vida privada, a esfera do segredo seria a mais restrita, circunscrita dentro das esferas da intimidade e da vida privada, caracterizada pela inacessibilidade absoluta de terceiros. Na esfera do segredo, "a ciência daquilo que a preenche pertence somente ao indivíduo, que o comunica a terceiros, normalmente com discrição e de forma parcimoniosa, apenas segundo o seu próprio critério de pertinência. Esta esfera exige mais rigorosa proteção legal contra a indiscrição" (BELLOQUE, Juliana Garcia. Sigilo bancário: análise crítica da LC 105/2001. São Paulo: Revista dos Tribunais, 2003, p. 40). O sigilo, por sua vez, é o instrumento para a tutela do segredo. Quebrado o sigilo, viola-se o segredo da informação.
} 
Conforme ressalvado por Antonio Scarance Fernandes, ${ }^{44}$ se a fase de investigação, por um lado, evita acusações apressadas e imotivadas; por outro, os elementos nela colhidos podem ser utilizados apenas para fundamentar a acusação e não um decreto condenatório, sob pena de se ferir os princípios constitucionais da ampla defesa e do contraditório.

Os atos de investigação não se confundem com atos de prova, porque não observam as garantias fundamentais da publicidade, do contraditório e da ampla defesa. Logo, não podem ser utilizados para amparar a sentença. ${ }^{45}$

Nessa linha, Marcos Alexandre Coelho Zilli diferencia elementos meramente informativos de provas: "os primeiros são obtidos na fase investigatória, sem a participação dialética das partes. Prestam-se para a fundamentação das medidas cautelares e também para a estruturação de uma acusação. As provas, por sua vez, têm o seu regime jurídico ligado ao contraditório judicial. São aquelas produzidas com a participação do acusador e do acusado e mediante a direta e a constante supervisão do julgador”. ${ }^{46}$

A classificação entre atos de investigação e de prova é diversa daquela anteriormente referida entre atos de investigação e de instrução (cf. item II.1). No primeiro caso, verifica-se o momento de realização do ato (se na fase preliminar ou processual) e a obediência aos corolários do devido processo legal (publicidade, contraditório e ampla defesa). Já, no segundo, leva-se em conta unicamente a carga decisória do ato, isto é, se

\footnotetext{
${ }^{43}$ Nesse sentido, dispõe o artigo 20 do Código de Processo Penal que "a autoridade assegurará no inquérito o sigilo necessário à elucidação do fato ou exigido pelo interesse da sociedade”.

${ }^{44}$ Teoria Geral..., p. 75.

${ }^{45}$ Aury Lopes Jr. enumera as principais características dos atos de prova e de investigação. Os primeiros visam a convencer o Juiz da verdade de uma afirmação; estão a serviço do processo e o integram; dirigem-se a formar um juízo de certeza; servem à sentença; exigem estrita observância da publicidade, contradição e imediação; são praticados ante o Juiz da causa. Já os atos de investigação referem-se a uma hipótese; estão a serviço da instrução preliminar; servem para formar um juízo de probabilidade; não exigem estrita observância da publicidade, contradição e imediação, que podem ser restringidas; embasam a opinio delicti do acusador; não estão destinados à sentença, mas a comprovar o fumus commissi delicti da imputação e fundamentar decisões interlocutórias proferidas na persecução prévia; podem ser praticados pelo Ministério Público ou pela Polícia Judiciária (Sistemas..., pp. 130/31). Também sobre a diferença entre atos de investigação e de prova, conferir COLOMER, Juan-Luis Gómez, "A investigação criminal: problemas atuais e perspectivas de unificação internacional" in Processo Penal e Estado de Direito. CHOUKR, Fauzi Hassan e AMBOS, Kai (orgs.). Campinas: Edicamp, 2002, pp. 222/23.

46 "O Pomar e as Pragas" in Boletim do Instituto Brasileiro de Ciências Criminais, n. ${ }^{\circ}$ 188, julho/2008, p. 02.
} 
visa a formar o convencimento judicial a respeito da imputação e das medidas cautelares tomadas nessa fase. ${ }^{47}$

Para os fins desse trabalho, será considerada a primeira classificação, por ser mais abrangente do que a segunda. De fato, o conceito de atos de investigação da primeira classificação $^{48}$ engloba os atos de investigação e de instrução mencionados na segunda.

Tais atos de investigação, reitere-se, não podem embasar a opinião do Juiz no momento da prolação da sentença. Ocasionalmente, admite-se a produção de atos de prova na fase investigatória. É o caso das provas antecipadas (que apresentam fundados riscos de perecimento) e das irrepetíveis (que não podem ser refeitas na instrução processual). Para tanto, exige-se incidente de produção antecipada de provas, que se efetua perante a Autoridade Judiciária, com participação das partes e total observância aos princípios do contraditório e da ampla defesa.

\section{II.3. Análise histórica da investigação criminal e a sua relação com os modelos de sistemas processuais penais}

No transcorrer da história, a investigação criminal assumiu várias formas, com diferentes cargas de poderes e deveres para o imputado, mas sempre com o propósito comum de obter dados sobre a materialidade e a autoria de eventual prática delitiva. Esta fase preliminar apresentou características próprias de acordo com o sistema processual penal existente (inquisitório, acusatório ou misto), que, por sua vez, se estruturou conforme

\footnotetext{
${ }^{47}$ Para compreender a diferença entre atos de investigação e de instrução, remete-se ao magistério de Marta Saad. Segundo a autora, a investigação criminal "é a pesquisa sistemática e seqüente do objeto, utilizando os meios de apoios técnicos disponíveis, e desenvolve-se pela informação, por meio de fontes regulares ou estimuladas, pela indagação técnica e pela posterior instrumentação, dependente dos recursos técnicos disponíveis". Já a instrução "consiste em atividade tendente a produzir prova do fato criminado, comunicando-o ao Judiciário". Assim, "com a redução a escrito da diligência efetuada, passa-se, então, da investigação à instrução". Por fim, conclui que "diz-se instruir porque é com base nos dados obtidos no inquérito policial que o juiz decide se há, ou não, fundamento para a acusação, bem com avalia se os requisitos para a decretação da prisão preventiva ou outra medida ou provimento cautelar estão, ou não, presentes faticamente" (O direito de defesa..., pp. 166/69).

${ }^{48}$ Definidos como aqueles praticados durante a persecução prévia, sem observância às garantias do devido processo legal, que amparam a opinião do Parquet e do Juiz a respeito da imputação e das decisões interlocutórias proferidas nessa fase.
} 
o modelo estatal vigente à época. ${ }^{49}$ Importa, aqui, examinar os aspectos essenciais de cada um desses sistemas, com realce para a investigação e a situação do imputado. ${ }^{50}$

O primeiro sistema processual penal foi o acusatório, que surgiu na Antigüidade Clássica (Grécia e Roma republicana), ${ }^{51}$ por causa do caráter predominantemente privado da acusação. Vicejou até o século XII na Europa Continental e para além disso na Inglaterra, onde se tornou o modelo vigente. Caracterizou-se pela separação das funções de acusar, defender e julgar, entre sujeitos processuais distintos. ${ }^{52}$

Nesse sistema, a persecução penal começava por iniciativa de órgão diverso do julgador, vigendo as garantias da independência e da imparcialidade do Juiz, da igualdade, do contraditório, da ampla defesa e da publicidade. ${ }^{53}$

Vale dizer, "o processo penal acusatório, ou processo de partes (em contraposição ao inquisitório), deve ser entendido, sinteticamente, como aquele em que as funções de acusar, defender e julgar são atribuídas a órgãos diversos, daí decorrendo os seguintes corolários: a1) os elementos probatórios colhidos na investigação prévia servem

49 Por meio da análise histórica dos sistemas processuais penais, verifica-se que "predomina o sistema acusatório nos países que respeitam mais a liberdade individual e que possuem uma sólida base democrática. Em sentido oposto, o sistema inquisitório predomina historicamente em países de maior repressão, caracterizados pelo autoritarismo ou totalitarismo, em que se fortalece a hegemonia estatal em detrimento dos direitos individuais” (LOPES Jr., Aury. Direito Processual Penal e sua conformidade constitucional. $3^{\mathrm{a}}$ ed.. Rio de Janeiro: Lumen Juris, 2008, vol. I, p. 56). Na mesma linha, ver BADARÓ, Gustavo Henrique Righi Ivahy. Ônus da prova no processo penal. São Paulo: Revista dos Tribunais, 2003, pp. 106/07.

${ }^{50}$ Para completo estudo histórico do processo criminal, compulsar MENDES DE ALMEIDA Jr., João. $O$ processo criminal brasileiro. $4^{\mathrm{a}}$ ed.. Rio de Janeiro: Freitas Bastos, vol. I, 1959. Ver também FERRAJOLI, Luigi, Direito e razão..., pp. 453/54.

${ }^{51}$ No Direito Romano, durante o período republicano, a investigação criminal, denominada inquisitio, era feita unicamente pelas partes. O acusador recebia do magistrado uma comissão, com poderes para realizar a investigação dentro de um prazo pré-determinado. Tal comissão conferia ao acusador e ao imputado o direito de dirigir-se aos lugares, reunir indícios, visitar e ouvir testemunhas, proceder a arresto de documentos e coisas necessárias à prova, tirar cópias e requerer autenticações e proceder a buscas e apreensões. O juiz conduzia, ex officio, a investigação apenas na ausência de um acusador (MORAES, Bismael B.. Direito e Polícia - Uma introdução à Polícia Judiciária. São Paulo: Revista dos Tribunais, 1986, pp. 123/24). A análise detalhada do processo penal romano é feita por Rogério Lauria Tucci: Lineamentos do processo penal romano. São Paulo: José Bushatsky, 1976.

${ }^{52}$ Segundo Luigi Ferrajoli, "pode-se chamar acusatório todo sistema processual que tem o juiz como um sujeito passivo rigidamente separado das partes e o julgamento como um debate paritário, iniciado pela acusação, à qual compete o ônus da prova, desenvolvida com a defesa mediante um contraditório público e oral e solucionado pelo juiz, com base em sua livre convicção” (Direito e razão..., p. 452). Sobre a definição de processo penal acusatório, ver também ZILLI, Marcos Alexandre Coelho, A iniciativa instrutória..., p. 38.

53 José Frederico Marques enuncia as características do sistema acusatório, verbis: “a) separação entre acusação, defesa e julgamento, uma vez que cada função é exercida por pessoas e órgãos entre si diversos; b) liberdade de defesa e igualdade de posição entre a acusação e o réu; c) procedimento público e dominado pela oralidade; d) julgamento popular, ou por órgãos judiciários imparciais; e) livre apresentação das provas pelas partes; f) ativação da causa pelas partes; g) o contraditório” (Elementos..., p. 92). Vide, também, BADARÓ, Gustavo Henrique Righi Ivahy, Ônus da prova..., pp. 102/04. 
exclusivamente para a formação do convencimento do acusador, não podendo ingressar no processo e serem valorados como provas; a2) o exercício da jurisdição depende de acusação formulada por órgão diverso do juiz; a3) todo o processo deve desenvolver-se em contraditório pleno, perante o juiz natural”. 54

Nesse modelo, a investigação preliminar era realizada pelas próprias partes ou conduzida por órgão diverso do julgador, conforme poderes previamente fixados em lei. A Autoridade Judiciária verificava a posteriori a legalidade da investigação ou, se necessário, autorizava previamente a realização de determinado ato (normalmente medidas restritivas de direitos fundamentais). O imputado era visto como sujeito de direitos e, como tal, tinha maior possibilidade de intervir na investigação, com o propósito de rebater a acusação.

Já o sistema inquisitório ${ }^{55}$ surgiu no período de Roma imperial, ${ }^{56}$ prosperou na Idade Média (Inquisições) e prevaleceu nos países da Europa continental até o século XVIII. Nele, o Juiz deixou de ser mero espectador e tornou-se o principal - para não dizer o único - ator da persecução penal, concentrando as funções de acusar, defender e julgar. O Magistrado deveria instaurar, de ofício, o processo, recolher as provas e proferir a sentença.

A investigação era secreta e feita pelo próprio julgador, que deveria inquirir as testemunhas e interrogar o imputado de modo a obter a sua confissão, podendo se valer de práticas de tortura. O imputado, visto como mero objeto de investigação, não tinha qualquer tipo de ingerência nessa fase. Mesmo durante o processo, atribuía-se limitado

\footnotetext{
54 GRINOVER, Ada Pellegrini. “A iniciativa instrutória do Juiz no processo penal acusatório” in Revista Brasileira de Ciências Criminais, n. ${ }^{\circ}$ 27, jul./set. de 1999, pp. 76/77.

55 Não se deve confundir inquisitoriedade com inquisitividade. A primeira, reitere-se, é definida como a junção das funções de acusar, defender e julgar em um único órgão, sem permitir a interferência das partes. Já a inquisitividade é uma característica do processo penal, conceituada como a busca da verdade pelo Juiz, e não inibe a participação dos interessados na persecução penal (SAAD, Marta, O direito de defesa..., pp. 154/58). Ver, também, TUCCI, Rogério Lauria. Direitos e garantias individuais no Processo Penal brasileiro. São Paulo: Saraiva, 1993, p. 38; e SCHOLZ, Leônidas Ribeiro. "Sistemas Processuais Penais e Processo Penal Brasileiro” in Revista dos Tribunais, n. ${ }^{\circ}$ 764, junho de 1999, p. 467.

${ }^{56} \mathrm{Na}$ época imperial de Roma, apesar de as partes possuírem poderes investigatórios, a investigação criminal era normalmente realizada por oficial público (agentes da Polícia Imperial, denominados irenarchae, curiosi, stationari), sendo denominada inquisitio generalis, pois não recaía sobre pessoa determinada, mas visava a todos em geral. Os agentes públicos poderiam prender os indiciados e seus cúmplices, interrogá-los e obter esclarecimentos sobre o crime. A inquisitio era reduzida a escrito e transmitida, com os indiciados, ao juiz, que prosseguia nas investigações. Com o término dessa fase, se houvesse a identificação do autor do crime, passava-se à verificação de sua responsabilidade por meio da instrução judicial (inquisitio specialis).
} 
direito de defesa ao imputado, pois se buscava, simplesmente, a confirmação dos elementos colhidos na instrução prévia. ${ }^{57}$

Por fim, há o sistema misto, que despontou, como realidade procedimental, no Código de Instrução Criminal Napoleônico de 1808, fortemente influenciado pelas idéias do movimento iluminista. ${ }^{58}$ Tal modelo disseminou-se por toda a Europa e países latinoamericanos, inclusive o Brasil, sendo tipicamente inquisitório na fase de investigação e acusatório na etapa processual. ${ }^{59}$

Luigi Ferrajoli ${ }^{60}$ criticou o sistema misto, que, na sua opinião, foi um “monstro nascido da junção entre os processos acusatório e inquisitório”, tendo a segunda fase, de caráter acusatório, tornado-se mera repetição ou encenação da primeira etapa inquisitória.

O sistema misto foi o adotado no Brasil, em que o inquérito policial (principal modelo de investigação preliminar) é tipicamente inquisitório, por inexistir, ainda, separação clara dos poderes processuais. A Autoridade Policial, responsável pelo inquérito, pauta-se pelo esclarecimento do fato constante da notícia de crime e deve reunir provas favoráveis à acusação ou ao imputado, indiscriminadamente. Por sua vez, a ação penal é notadamente acusatória, marcada pela dialética processual entre acusador (Ministério Público ou, excepcionalmente, o ofendido) e acusado e pela existência de um julgador imparcial. $^{61}$

Segundo Rogério Lauria Tucci, “alastrando-se pela Europa e, por igual, pelos países americanos de origem latina, esse novo tipo procedimental, denominado misto, foi

\footnotetext{
${ }^{57}$ Como assinalado por Bruno Calabrich, "em verdade, sequer se pode fazer uma distinção, nesse sistema, entre a atividade de investigação e de instrução definitiva, considerando que todos os elementos colhidos pelo juiz inquisidor são considerados provas, na medida em que suficientemente aptas à formação de seu convencimento" (Investigação..., p. 72). Sobre as características do sistema inquisitório, ver BADARÓ, Gustavo Henrique Righi Ivahy, Ônus da prova..., pp. 104/06.

${ }^{58} \mathrm{Em}$ Roma, existiu procedimento bipartido, com duas etapas bem distintas, que pode ser considerado o embrião do sistema misto de persecução penal. Na fase inquisitiva, eram levantados os elementos de prova do crime e de sua autoria, enquanto na fase acusatória desenvolvia-se o contraditório e ocorria o julgamento da causa (MORAES, Bismael B., Direito e Polícia..., p. 124).

59 “Trata-se, na verdade, de um sistema inquisitório, em sua essência, e formalmente acusatório, porquanto o poder penal seguiu pertencendo ao Estado, dividido, todavia, em dois órgãos: um, o responsável pela função de requerer o reconhecimento da prática do injusto (acusar) e o outro, responsável pela função de afirmar ou não a sua existência (julgar)” (ZILLI, Marcos Alexandre Coelho, A iniciativa instrutória..., p. 94).

${ }^{60}$ Direito e razão..., p. 454.

${ }^{61}$ Ressalve-se que, no Brasil, a qualificação como “sistema misto” vale para a persecução penal vista como um todo, isto é, abrangendo a fase preliminar de investigação e a fase processual. Se considerarmos apenas esta última etapa, o sistema brasileiro, após o advento da Constituição da República de 1988, é tipicamente
} 
também, obviamente, implantado no Brasil, em que a persecutio criminis se desenvolve em duas fases, a saber: a) a primeira, realizada, quase toda, inquisitorialmente por agente estatal encarregado da investigação criminal, em regra pertencente à polícia judiciária, para a constatação da prática delitiva ou contravencional e da respectiva autoria; e b) a segunda, denominada de ação penal, dirigida por órgão do Poder Judiciário, e com a presença dos órgãos técnicos da acusação e da defesa, postos em contradição recíproca, num procedimento público e, ainda que parcialmente, informado pela oralidade”, ${ }^{6}$

Vale ressalvar que, para alguns juristas, a simples separação das funções processuais seria insuficiente para caracterizar um sistema como acusatório ou inquisitório. O principal critério diferenciador seria a gestão da prova: se esta fosse de responsabilidade das partes, o sistema seria acusatório, no qual o Juiz funcionaria como mero espectador; se estivesse a cargo do Juiz, o sistema seria inquisitório.

No Brasil, esposa essa idéia Jacinto Nelson de Miranda Coutinho, ${ }^{63}$ para quem a diferenciação dos sistemas processuais entre acusatório ou inquisitório seria feita por meio do critério referente à gestão da prova.

Todavia, conforme adverte Ada Pellegrini Grinover, ${ }^{64}$ o critério da gestão probatória não pode ser empregado para a classificação acusatório-inquisitório. Segundo a autora, a iniciativa probatória é relevante para distinguir o adversarial system, próprio do sistema anglo-saxão, do inquisitorial system, existente nos países que seguiram o modelo jurídico romano-germânico. O primeiro é aquele em que as partes são responsáveis pelo andamento do processo e produção das provas; enquanto, no segundo, a gestão probatória fica a cargo do Juiz.

acusatório. Nesse sentido, conferir SCHOLZ, Leônidas Ribeiro, "Sistemas Processuais Penais e Processo Penal Brasileiro"..., p. 466.

${ }^{62}$ TUCCI, Rogério Lauria. Persecução penal, prisão e liberdade. São Paulo: Saraiva, 1980, p. 79.

63 "As reformas parciais do CPP e a gestão da prova: segue o princípio inquisitivo" in Boletim do Instituto Brasileiro de Ciências Criminais, n. ${ }^{\circ}$ 188, julho/2008, p. 11. Na mesma linha, Aury Lopes Jr. salienta que a ação penal, no Brasil, seria inquisitória, pois o Juiz possui poderes instrutórios, como o previsto no artigo 156 do Código de Processo Penal, verbis: "a prova da alegação incumbirá a quem a fizer; mas o juiz poderá, no curso da instrução ou antes de proferir sentença, determinar, de ofício, diligências para dirimir dúvida sobre ponto relevante" (Sistemas..., pp. 14/15). Vide, também, do mesmo autor, Direito Processual Penal..., pp. $69 / 74$.

${ }^{64}$ GRINOVER, Ada Pellegrini, “A iniciativa instrutória do Juiz no processo penal acusatório”..., p. 72. Sobre a distinção entre adversarial system e inquisitorial system, ver BADARÓ, Gustavo Henrique Righi Ivahy, Ônus da prova..., pp. 125/38. 
Em outras palavras, “a dicotomia inquisitorial e 'adversarial', largamente difundida entre os membros da família anglo-saxônica, leva em consideração, como critério distintivo, a preponderante atuação do juiz no desenvolvimento da marcha do processo penal - característica primordial do primeiro - e o envolvimento prevalente das partes processuais - crucial no segundo". 65

Nessa linha de raciocínio, um sistema acusatório pode adotar o adversarial ou o inquisitorial system, caso a iniciativa probatória esteja nas mãos das partes ou do Juiz, respectivamente. Atualmente, com fulcro em uma concepção publicista do processo, caminha-se para um incremento dos poderes instrutórios do Juiz na fase processual, com vistas a descobrir a verdade, em seu maior grau de probabilidade, e garantir a igualdade real entre as partes - o que não desnatura o seu caráter acusatório. ${ }^{66}$

Do escorço histórico ora traçado, infere-se que a posição do imputado na investigação criminal modificou-se bastante ao longo dos séculos. Partiu-se de uma visão do imputado como mero objeto de investigação, sem poder interferir em seu deslinde, típica do sistema inquisitório; e alcançou-se a noção de imputado como sujeito de direitos e ativo participante da persecução prévia, conforme previsto no sistema acusatório.

Hoje em dia, não se pode falar em sistemas acusatórios ou inquisitórios “puros”. Os modelos processuais vigentes em cada país combinam características de ambos os sistemas, podendo prevalecer um ou outro aspecto. ${ }^{67}$

Todavia, a maioria dos Estados modernos democráticos almejam, ao menos em tese, um sistema predominantemente acusatório, devido às suas inúmeras vantagens em comparação ao sistema inquisitório. "Do ponto de vista ideológico, trata-se de uma forma democrática do exercício do poder, na medida em que é dado ao destinatário do ato o

65 ZILLI, Marcos Alexandre Coelho, A iniciativa instrutória..., p. 42. O autor enumera as principais características do sistema “adversarial”, a saber: (i) controle das partes sobre a marcha processual; (ii) presença de um julgador imparcial e passivo; (iii) permanente sustentação de uma disputa bilateral e (iv) igualdade de oportunidade e limitações (Ibid., pp. 44/49).

${ }^{66}$ GRINOVER, Ada Pellegrini, “A iniciativa instrutória do Juiz no processo penal acusatório”..., pp. 72/74. Leciona Gustavo Henrique Righi Ivahy Badaró que “o modelo acusatório não é incompatível com um juiz dotado de poderes para determinar ex officio a produção de provas. Atualmente, o juiz penal sempre é dotado de poderes instrutórios, variando apenas a amplitude de tais poderes” (Ônus da prova..., p. 123). Também Vicente Greco Filho destaca a possibilidade de o Magistrado realizar atividade instrutória, em um processo penal acusatório, o que deve se realizar de forma imparcial, isto é, sem privilegiar acusação ou defesa (Tutela Constitucional das Liberdades. São Paulo: Saraiva, 1989, p. 127).

67 BADARÓ, Gustavo Henrique Righi Ivahy, Ônus da prova..., pp. 101/02 e LOPES Jr., Aury, Direito Processual Penal..., p. 56. 
poder de influenciar a sua formação. O modelo acusatório é uma garantia para o acusado. Sob o aspecto do funcionamento interno, a estrutura dialética do processo acusatório permite uma maior eficiência tanto para a resolução das questões de direito, quanto para as questões de fato, principalmente no aspecto probatório”. ${ }^{6}$

\section{II.4. A investigação pelo Ministério Público}

Atualmente, há uma tendência mundial em se atribuir ao Ministério Público a direção da instrução preliminar, em substituição ao inquérito policial e ao juizado de instrução. ${ }^{69}$

A implantação da investigação ministerial foi objeto de diversas reformas processuais na Europa: Alemanha em 1974; Portugal em 1987; e Itália em 1988. De igual maneira, alguns países latino-americanos, em atenção às diretrizes do Código de Processo Penal Modelo para a Ibero-América, incorporaram esse modelo investigatório. ${ }^{70}$ Por fim, o

${ }^{68}$ BADARÓ, Gustavo Henrique Righi Ivahy, Ônus da prova..., pp. 115/16. Para Juan-Luis Gómez Colomer, o processo penal dos Estados democráticos caracteriza-se por dois pressupostos básicos: o princípio acusatório e um juízo oral e público (“A investigação criminal: problemas atuais e perspectivas de unificação internacional” in Processo Penal e Estado de Direito. CHOUKR, Fauzi Hassan e AMBOS, Kai (orgs.). Campinas: Edicamp, 2002, p. 202).

69 Salienta Fauzi Hassan Choukr que "o novo modo de enfocar o processo penal alterou a estrutura da investigação criminal, deixando-a no mais das vezes a cargo do Ministério Público, que passa a ter definitivamente a Polícia Judiciária como sua longa manus para a tarefa, e reservou ao juiz um papel distanciado deste momento, a não ser e aí está uma das grandes linhas evolutivas, para os casos da necessidade de jurisdicionalização de uma medida, notadamente aquelas atinentes à liberdade pessoal, mas também ligada, muitas vezes, à produção de meios de prova como interceptação telefônica, v.g” (Garantias Constitucionais na Investigação Criminal. $2^{a}$ ed.. Rio de Janeiro: Lumen Juris, 2001, pp. 113/14). Na mesma linha, disserta Marta Saad, verbis: “...o que se vê, hoje, na Europa, é uma tendência no sentido de se atribuírem as funções que antes eram do juizado de instrução ao Ministério Público, com a adoção de uma etapa investigativa, semelhante ao nosso inquérito policial, mas sendo o Ministério Público o titular dessa fase preparatória. No Brasil, já se vislumbra essa solução, com a alardeada necessidade de se entregar o comando e vigilância da fase preliminar ao Ministério Público, cabendo ao juiz apenas tomar conhecimento dos incidentes, chancelando decisões do Ministério Público, idéia essa encampada pelo Projeto de Lei 4.209/2001” (O direito de defesa..., pp. 190/91). Ver, também, LOPES Jr., Aury, Direito Processual Penal..., pp. 229/34.

${ }^{70} \mathrm{O}$ artigo 68 do Código de Processo Penal Modelo para a Ibero-América previu a condução da persecução preliminar pelo Ministério Público. Esse sistema foi adotado nos novos Códigos de Processo Penal da Bolívia, Chile, Equador, Peru, Venezuela e Colômbia (CHOUKR, Fauzi Hassan. "O relacionamento entre o Ministério Público e a Polícia Judiciária no processo penal acusatório” in Processo Penal e Estado de Direito. CHOUKR, Fauzi Hassan e AMBOS, Kai (orgs.). Campinas: Edicamp, 2002, pp. 154/56). Sobre a instituição da investigação ministerial nos países europeus e latino-americanos, conferir COLOMER, JuanLuis Gómez. "La instrucción del Proceso Penal por el Ministerio Fiscal: aspectos estructurales a la luz del 
Estatuto de Roma, que instituiu o Tribunal Penal Internacional, também aderiu à investigação do crime pelo Ministério Público. ${ }^{71}$

No Brasil, há forte controvérsia sobre a possibilidade de investigação do crime diretamente pelo Ministério Público. Para alguns, a atividade investigatória é atribuição exclusiva da Polícia Judiciária, por força do disposto no artigo 144, §4º da Constituição da República. $^{72}$

Leciona Adauto Suannes ${ }^{73}$ que o artigo 129 da Constituição da República, que cuida das funções institucionais do Ministério Público, não outorga a este órgão legitimação para instaurar e promover procedimento investigatório criminal, o que, segundo o próprio texto constitucional, é atribuição privativa da Polícia Judiciária.

Assim, o Ministério Público não poderia apurar, por conta própria, possível conduta criminosa, pois extrapolaria as suas funções. O órgão ministerial deveria se limitar a participar ativamente da investigação preliminar, requisitando as diligências que entender pertinentes, bem como fiscalizar a atividade policial. ${ }^{74}$

derecho comparado" in Cuadernos de Doctrina y Jurisprudencial Penal, n. ${ }^{\circ}$ 07, publicación de Ad-Hoc S.R.L, Buenos Aires, pp. 901/36.

${ }^{71}$ Conforme previsto no artigo 15 do Estatuto de Roma. A respeito do procedimento de investigação criminal perante o Tribunal Penal Internacional, conferir o seguinte artigo: COLOMER, Juan-Luis Gómez. "La investigacion del crimen en el proceso penal ante el Tribunal Penal Internacional” in Revista Penal, n. ${ }^{\circ}$ 12, publicación semestral de LA LEY S/A, en colaboración con las Universidades de Huelva, Salamanca, Castilla-La Mancha y Pablo de Olavide, Sevilla, pp. 72/97.

${ }^{72}$ Artigo 144, $\S 4^{\circ}$, da Constituição da República: “Às polícias civis, dirigidas por delegados de polícia de carreira, incumbem, ressalvada a competência da União, as funções de polícia judiciária e a apuração de infrações penais, exceto as militares".

${ }^{73}$ SUANNES, Adauto. Os fundamentos éticos do devido processo penal. $2^{\text {a }}$ ed.. São Paulo: Revista dos Tribunais, 2004, p. 228. Afirma o autor que "o fortalecimento da Instituição, a independência e a autonomia que the são asseguradas, necessárias ao desempenho de suas superiores atribuições, têm levado, lamentavelmente, alguns de seus membros ao cometimento de equívocos, pois têm instaurado procedimentos investigatórios criminais, invadindo as atribuições que, constitucionalmente, são deferidas à Polícia Judiciária. Como justificativa para essa inconstitucional invasão funcional alegam que entre as suas funções institucionais está a de 'promover, privativamente, a ação penal, na forma da Lei', como está no art. 129, I, da CF de 1988. 'Promover a ação penal pública' não significa promover a investigação criminal, mas, caso seja necessária, requisitá-la à autoridade competente, que é, segundo o texto constitucional, a polícia judiciária” (Ibid., pp. 228/29).

${ }^{74}$ Rogério Lauria Tucci é contrário à investigação pelo Ministério Público, que, a seu ver, "consubstancia-se numa atuação afrontosa do due process of law, e, especificamente, das preceituações contidas nos incs. LIV e LV do art. 5, da CF”. Para o autor, “o fato de ser o Ministério Público titular da ação, na defesa do interesse punitivo estatal, mostra-se, ele próprio, inibidor da sua atuação investigatória, posto que, como logo acima ressaltado, manifestamente interessado na colheita de prova desfavorável ao investigado, e, reflexivamente, desinteressado da que lhe possa beneficiar (Ministério Público e investigação criminal. São Paulo: Revista dos Tribunais, 2004, pp. 80/87). Tal autor cita alguns juristas contrários à investigação ministerial, a saber: Antonio Scarance Fernandes, Sérgio Marcos de Moraes Pitombo, Antônio Evaristo de Moraes Filho, Guilherme de Souza Nucci, Fernando da Costa Tourinho Filho, Alberto Silva Franco, Jacinto Nélson de 
Tal entendimento foi esposado pelo Supremo Tribunal Federal, em acórdão datado de 06 de maio de 2003. In verbis: “A Constituição Federal dotou o Ministério Público do poder de requisitar diligências investigatórias e a instauração de inquérito policial (CF, art. 129, VIII). A norma constitucional não contemplou a possibilidade do parquet realizar e presidir inquérito policial. Não cabe, portanto, aos seus membros inquirir diretamente pessoas suspeitas de autoria de crime. Mas requisitar diligência nesse sentido à autoridade policial". ${ }^{75}$

No entanto, o Pretório Excelso voltou a debater a constitucionalidade da investigação ministerial por ocasião do julgamento do $\mathrm{HC} n .^{\circ} 84.548 / \mathrm{SP}$, cujo relator é o Min. Marco Aurélio. Nesse processo, em suma, questiona-se a validade de denúncia oferecida com base em elementos colhidos pelo Ministério Público. Até o momento, foram proferidos dois votos: o do relator, que deferiu a ordem e se posicionou contrário à investigação ministerial; e o do Min. Sepúlveda Pertence, que indeferiu o trancamento da ação penal e assentiu com a atribuição de poderes investigatórios ao Ministério Público. Atualmente, o julgamento encontra-se suspenso em razão do pedido de vista do Min. Cezar Peluso.

Por outro lado, há quem sustente, com amparo no artigo 129, incisos I, VI, VII e VIII, da Constituição da República; ${ }^{76}$ artigo $4^{\circ}$, parágrafo único, do Código de Processo Penal; ${ }^{77}$ artigo 26, incisos I e II, da Lei n. ${ }^{0}$ 8.625/93 (Lei Orgânica Nacional do Ministério Público) ${ }^{78}$ e artigos $7^{\circ}$ e $8^{\circ}$ da Lei Complementar n. ${ }^{0}$ 75/1993 (Estatuto do Ministério

Miranda Coutinho, José Carlos Fragoso, Luiz Guilherme Vieira, Marco Antônio Rodrigues Nahum, Marta Saad, dentre outros (Ministério Público..., pp. 31/45).

${ }^{75}$ STF, RHC n. ${ }^{\circ}$ 81.326-7/DF, Rel. Min. Nelson Jobim, j. 06.05.2003.

76 “Art. 129. São funções institucionais do Ministério Público:

I - promover, privativamente, a ação penal pública, na forma da lei;

(...)

VI - expedir notificações nos procedimentos administrativos de sua competência, requisitando informações e documentos para instruí-los, na forma da lei complementar respectiva;

VII - exercer o controle externo da atividade policial, na forma da lei complementar mencionada no artigo anterior;

VIII - requisitar diligências investigatórias e a instauração de inquérito policial, indicados os fundamentos jurídicos de suas manifestações processuais".

${ }^{77}$ Dispõe essa norma que "a competência definida nesse artigo não excluirá a de autoridades administrativas, a quem por lei seja cometida a mesma função".

78 “Art. 26. No exercício de suas funções, o Ministério Público poderá:

I - instaurar inquéritos civis e outras medidas e procedimentos administrativos pertinentes e, para instruí-los:

a) expedir notificações para colher depoimento ou esclarecimentos e, em caso de não comparecimento injustificado, requisitar condução coercitiva, inclusive pela Polícia Civil ou Militar, ressalvadas as prerrogativas previstas em lei; 
Público da União), ${ }^{79}$ que o Parquet poderia dirigir a investigação criminal, não se limitando a atuar como mero fiscal da atividade desenvolvida pela Polícia Judiciária.

Em alguns Estados, como São Paulo, o Ministério Público editou atos normativos com o objetivo de regulamentar os procedimentos investigatórios conduzidos diretamente por seus membros (Atos Normativos n. ${ }^{\circ}$ 314-PGJ/CPJ, de 27 de junho de 2003, e n. ${ }^{\text {3 } 324-P G J / C G M P / C P J, ~ d e ~} 29$ de agosto de 2003). ${ }^{80}$

Sinteticamente, são levantados os seguintes argumentos em favor da investigação ministerial: (i) por ser o Ministério Público titular da ação penal de iniciativa pública teria o poder de realizar diligências investigatórias quando necessário (é o que se denomina teoria dos poderes implícitos: quem pode o mais, pode o menos); (ii) o artigo $4^{\circ}$, parágrafo único, do Código de Processo Penal, permitiria a investigação por autoridades

b) requisitar informações, exames periciais e documentos de autoridades federais, estaduais e municipais, bem como dos órgãos e entidades da administração direta, indireta ou fundacional, de qualquer dos Poderes da União, dos Estados, do Distrito Federal e dos Municípios;

c) promover inspeções e diligências investigatórias junto às autoridades, órgãos e entidades a que se refere a alínea anterior;

II - requisitar informações e documentos a entidades privadas, para instruir procedimentos ou processo em que oficie”.

79 “Art. $7^{\circ}$. Incumbe ao Ministério Público da União, sempre que necessário ao exercício de suas funções institucionais:

I - instaurar inquérito civil e outros procedimentos administrativos correlatos;

II - requisitar diligências investigatórias e a instauração de inquérito policial e de inquérito policial militar, podendo acompanhá-los e apresentar provas;

III - requisitar à autoridade competente a instauração de procedimentos administrativos, ressalvados os de natureza disciplinar, podendo acompanhá-los e produzir provas”.

“Art. 8. Para o exercício de suas atribuições, o Ministério Público da União poderá, nos procedimentos de sua competência:

I - notificar testemunhas e requisitar sua condução coercitiva, no caso de ausência injustificada;

II - requisitar informações, exames, perícias e documentos de autoridades da Administração Pública direta ou indireta;

III - requisitar da Administração Pública serviços temporários de seus servidores e meios materiais necessários para a realização de atividades específicas;

IV - requisitar informações e documentos a entidades privadas;

V - realizar inspeções e diligências investigatórias;

VI - ter livre acesso a qualquer local público ou privado, respeitadas as normas constitucionais pertinentes à inviolabilidade do domicílio;

VII - expedir notificações e intimações necessárias aos procedimentos e inquéritos que instaurar;

VIII - ter acesso incondicional a qualquer banco de dados de caráter público ou relativo a serviço de relevância pública;

IX - requisitar o auxílio de força policial”.

${ }^{80} \mathrm{O}$ artigo $2^{\circ}$ do Ato Normativo n. ${ }^{\circ}$ 314-PGJ/CPJ, de 27 de junho de 2003, estabelece que "o membro do Ministério Público, no exercício de suas funções na área criminal, poderá, de ofício ou em face de representação ou outra peça de informação, instaurar procedimento administrativo criminal quando, para a formação de seu convencimento, entender necessários maiores esclarecimentos sobre o caso ou o aprofundamento da investigação criminal produzida”. Também o Ato Normativo n. ${ }^{0}$ 324-PGJ/CGMP/CPJ, de 29 de agosto de 2003, que criou o Grupo de Atuação Especial de Controle Externo da Atividade Policial GECEP, previu procedimento investigatório realizado pelo Ministério Público (artigo $2^{\circ}$, caput e $\S 1^{\circ}$ ). Adauto Suannes alerta para a inconstitucionalidade de tais diplomas: Os fundamentos..., pp. 229/30. 
administrativas diversas da Polícia Judiciária, inclusive o Parquet; (iii) se o Ministério Público pode oferecer denúncia, sem prévio inquérito policial, poderia, por conseguinte, investigar diretamente. ${ }^{81}$

Costuma-se alegar que a investigação ministerial decorreria da própria natureza da persecução preliminar, cujo escopo primordial seria a formação da opinio delicti do órgão acusatório. Como conseqüência, seria razoável a condução da investigação pelo próprio destinatário dos elementos informativos obtidos e que deverá se manifestar sobre o prosseguimento ou não da persecução penal. ${ }^{82}$

Ocorre que essa idéia é falaciosa, pois, na verdade, o Ministério Público não é o único destinatário do resultado da investigação criminal. Os dados reunidos nessa fase preliminar fundamentam, simultaneamente, a opinião do órgão ministerial (que poderá oferecer denúncia ou requerer arquivamento) e a da Autoridade Judiciária (que poderá receber ou rejeitar a denúncia; ou homologar ou discordar do arquivamento).

Além disso, a Polícia Judiciária, como o próprio nome diz, não está a serviço do Parquet, mas do Poder Judiciário, devendo recolher dados relevantes para a acusação e o imputado. ${ }^{83}$

Ademais, se o Ministério Público presidir a instrução preliminar, a atividade investigatória penderá em favor da acusação, olvidando-se dos elementos relevantes para o

\footnotetext{
${ }^{81}$ Rogério Lauria Tucci enumera alguns doutrinadores favoráveis à investigação ministerial: Hélio Tornaghi, José Frederico Marques, Julio Fabbrini Mirabete, Hugo Nigro Mazzilli, Lenio Luiz Streck, Luciano Feldens, Marcellus Polastri Lima, Aury Lopes Jr., dentre outros (Ministério Público..., pp. 13/25). Afirma Aury Lopes Jr. que “o Ministério Público não só está legalmente autorizado a acompanhar ativamente a atividade policial no curso do inquérito, como também a investigar e a realizar sua própria investigação preliminar, vista como um procedimento administrativo pré-processual” (Sistemas..., p. 149). Adilson Mehmeri entende que o Ministério Público, em certas ocasiões, teria o poder de "avocar" o inquérito policial e, com isso, presidir a investigação preliminar (MEHMERI, Adilson. Inquérito Policial (dinâmica). São Paulo: Saraiva, 1992, p. 428). Conferir, também, CALABRICH, Bruno, Investigação..., pp. 111/36.

${ }^{82}$ Além disso, outros aspectos amparariam a investigação do crime pelo Parquet: (i) a pretensa imparcialidade do Promotor investigador na elucidação dos fatos; (ii) a melhor definição do valor probatório dos atos praticados durante a investigação, que serviriam apenas para embasar eventual acusação formal ou pedido de arquivamento; (iii) maior celeridade e economia processual; (iv) fortalecimento da figura do Juiz, que se limitaria a decidir questões relacionadas a direitos fundamentais, preservando-se a sua imparcialidade; (v) melhor distribuição do poder com a criação do Juiz de garantias para fiscalizar as ações do Promotor investigador (LOPES Jr., Aury, Sistemas..., pp. 89/90). Vide, também, CALABRICH, Bruno, Investigação..., pp. 131/36.

${ }^{83}$ Ensina Marta Saad que "outro equívoco, usualmente repetido, é que o inquérito policial é dirigido ao Ministério Público, tendo tal entendimento inclusive se repetido no art. $7^{\circ}$, caput, do Projeto de Lei 4.209/2001. O engano, aí, está em não se ver o inquérito, realizado pela polícia judiciária, como instrumento de justiça, que serve ao juiz e também ao acusado, o qual precisa saber sobre a viabilidade ou não da ação penal que lhe seja proposta" (O direito de defesa..., pp. 151/52).
} 
imputado. Compreenda-se que “o Ministério Público, como eventual parte acusadora, pode não dispor de imparcialidade suficiente para conduzir a primeira fase da persecução penal, podendo vir a causar prejuízos ao acusado e à sua defesa”, ${ }^{84}$

A bem da verdade, o Ministério Público, como se aprofundará adiante, não é uma instituição imparcial e nem é possível concebê-lo como tal. ${ }^{85}$ Para superar esta deficiência, alguns ordenamentos jurídicos estrangeiros estabeleceram o dever de o Ministério Público colher elementos favoráveis à acusação e ao imputado - o que, na prática, mostrou-se ineficaz. Isso porque "o que move a atuação do Ministério Público é a possibilidade de o investigado ser processado e condenado. Não se trata de esconder elementos favoráveis à defesa, se existentes, pois isso configuraria grave infração funcional, mas de dirigir a investigação segundo propósitos e intenções da acusação, descurando-se na colheita do que é favorável à defesa” ${ }^{86}$

Somos da opinião de que as normas vigentes no ordenamento jurídico brasileiro não dão lugar à investigação criminal pelo Ministério Público, atribuindo tal atividade exclusivamente à Polícia Judiciária. A falta de previsão legal, mormente no que diz respeito ao procedimento, desautoriza a investigação ministerial, que se desenrolaria de forma inadequada e com claro prejuízo ao direito de defesa do imputado. ${ }^{87}$

No entanto, mais importante do que saber qual o órgão responsável pela investigação pública é definir a posição do imputado na persecução prévia, com o devido respeito aos seus direitos e garantias constitucionais. Independentemente de a investigação pública ser realizada pela Polícia Judiciária ou pelo Ministério Público, o que importa é o tratamento do imputado como sujeito de direitos, desde o início da persecução penal, garantindo-lhe o efetivo exercício do direito de defesa e a paridade de armas com a acusação.

\footnotetext{
${ }^{84}$ Ibid., p. 192. Nesse passo, assinale-se que “o Ministério Público é parte acusadora e, conseqüentemente, não pode ser neutro, pelo que dificilmente poderá realizar uma investigação imparcial, e muito menos garantidora” (COLOMER, Juan-Luis Gómez, “A investigação criminal: problemas atuais e perspectivas de unificação internacional”..., p. 217).

${ }^{85}$ A imparcialidade é atributo exclusivo do Juiz, sendo preservada justamente pela parcialidade das partes, isto é, do Ministério Público e do imputado. O Parquet, como assevera Aury Lopes Jr., é o “contraditor natural do imputado”, sendo "ilógica sua construção a partir da imparcialidade” (Sistemas..., p. 92).

${ }^{86}$ SCARANCE FERNANDES, Antonio, Teoria Geral..., p. 84.

${ }^{87}$ Segundo Antonio Scarance Fernandes, é necessário que “a atuação do Ministério Público na investigação seja regulada por lei, com regras que especifiquem os poderes e os limites de sua atividade investigatória, a forma de relação com as entidades policiais e as formas como serão garantidos os direitos constitucionais do
} 
Desse modo, se determinado ordenamento jurídico prevê a investigação criminal pelo órgão acusatório, torna-se imprescindível conferir igual oportunidade ao imputado, sob pena de se causar desequilíbrio inaceitável em um processo penal de partes.

\section{II.5. A investigação criminal defensiva: delimitação do tema}

A investigação criminal defensiva é matéria estranha ao ordenamento jurídico pátrio, que, no modelo atual, prevê procedimento investigatório dirigido apenas pela Polícia Judiciária.

Todavia, tal possibilidade vem sendo cada vez mais discutida pela doutrina jurídica nacional e estrangeira, por ser vista como forma de compensar o movimento em favor da atribuição de poderes investigatórios ao Ministério Público. Tal idéia foi assim colocada por Antonio Scarance Fernandes, litteris: “A prática evidenciou que o Ministério Público, quando encarregado de dirigir ou supervisionar a investigação, foca sua atenção na obtenção de elementos que possam sustentar a sua futura acusação o que acaba prejudicando a pessoa suspeita, tendo em vista o risco de desaparecerem informes importantes para a sua defesa e demonstração de sua inocência. Decorre, daí, a preocupação em abrir para o investigado a possibilidade de investigação privada, como já sucede nos Estados Unidos. Trata-se de assunto que, com o avanço do Ministério Público para a investigação também entre nós, provavelmente, passará a ser objeto de maior atenção", ${ }^{88}$

De igual maneira, José Barcelos de Souza ressalta a necessidade de se atribuir poderes investigatórios ao imputado para contrabalançar a investigação ministerial. In verbis: “O que muito pesa, porém, em favor de uma regulamentação já, entre nós, de direitos investigatórios da defesa, é o fato de que aqui o Ministério Público tem investigado, mas, para acusar, sem qualquer comprometimento, por força de lei, com os interesses da defesa, e por isso mesmo completamente à revelia dela, à qual não é garantida

investigado, tais como o direito de acesso aos autos de investigação, o direito ao silêncio, o direito de acompanhar a investigação por meio do advogado” (Ibid., pp. 100/01).

88 "Rumos da investigação no direito brasileiro" in Boletim do Instituto Manoel Pedro Pimentel, Ano V, n. ${ }^{\circ}$ 21, jul./set. 2002, p. 13. 
sequer a faculdade de requerer diligências, diferentemente do que ocorre no inquérito policial”. 89

Na mesma linha, Marcos Alexandre Coelho Zilli, em recente artigo, escreveu que “a concessão de poderes investigatórios ao Ministério Público no caso brasileiro é aspecto setorial que não pode ser desvinculado de um sistema que lhe empresta coerência. Em outras palavras, o reforço dos poderes de uma das partes da relação processual não pode ser arquitetado sem um correspondente reforço em favor da parte contrária. E, nessa dinâmica, não se pode olvidar figurar o acusado, invariavelmente, em uma posição inferiorizada e que será tão mais acentuada quanto mais graves forem os desníveis sociais do país. Logo, mudanças constitucionais e processuais dirigidas à implementação de poderes investigatórios ao Ministério Público deverão vir acompanhadas, necessariamente, de uma permissão, em igual medida, para o investigado". ${ }^{90}$

Infere-se dos sobreditos excertos doutrinários que o Ministério Público, enquanto encarregado da instrução preliminar, atua parcialmente, com o propósito de demonstrar a tese acusatória, descurando-se dos informes favoráveis ao imputado. Por tal motivo, se o Parquet for o responsável pela investigação pública, é de rigor, em atenção aos postulados da igualdade e da ampla defesa, que se faculte ao imputado a possibilidade de exercer atividade investigatória, a fim de reunir elementos de convicção aptos a afastar a imputação que pesa contra si.

De outra parte, se a investigação preliminar for dirigida pela Polícia Judiciária, a investigação defensiva, a princípio, não seria imprescindível, em razão do dever de imparcialidade deste órgão. Entretanto, o que se constata empiricamente é que mesmo a investigação policial é tendencialmente acusatória e, em certa medida, restringe a participação da defesa.

Assim, como forma de assegurar a efetiva isonomia entre as partes na persecução penal e o direito de defesa do imputado, a investigação defensiva deve ser admitida tanto nos ordenamentos que adotam a investigação ministerial quanto a policial.

${ }^{89}$ SOUZA, José Barcelos de. "Poderes da defesa na investigação e investigação pela defesa”, notas referentes à palestra proferida no "IV Jornadas Brasileiras de Direito Processual Penal", realizado no município do Guarujá/SP, nos dias 06 a 09 de novembro de 2004, p. 02. Disponível na internet: "www.iamg.org.br". Acesso em 03 de março de 2008.

${ }^{90}$ ZILLI, Marcos Alexandre Coelho. "Os bons ventos de Haia” in Boletim do Instituto Brasileiro de Ciências Criminais, n. ${ }^{\circ}$ 190, setembro/2008, p. 14. 
Não obstante, há quem sustente que a investigação defensiva, apesar de plausível no plano teórico, seria impossível na prática, principalmente no Brasil, devido à precária situação econômica dos imputados, que não teriam condições de sustentar defensor particular. Por conta disso, haveria uma maior desigualdade entre os imputados, já que apenas uma minoria seria capaz de efetuar atividade investigatória. ${ }^{91}$

Tal posição não se afigura a mais adequada, pois, se o imputado não puder arcar com advogado, o Estado deve fornecer defensor público para conduzir a investigação. Diga-se: a condição econômica do imputado não inviabiliza a investigação defensiva.

Saliente-se, outrossim, que a investigação defensiva não se confunde com a participação do defensor nos autos da investigação pública. Apesar de ambas as formas serem concretização do direito de defesa e, mais particularmente, dos direitos à prova e à investigação, elas não se equivalem. Ao participar da investigação pública, o defensor está circunscrito aos rumos dados à persecução prévia pelo órgão público e sua intervenção restringe-se à proteção dos interesses mais relevantes do imputado, principalmente seus direitos fundamentais. ${ }^{92}$

Na investigação defensiva, que se desenvolve totalmente independente da investigação pública, cabe ao defensor traçar a estratégia investigatória, sem qualquer tipo de subordinação às autoridades públicas, devendo apenas respeitar os critérios constitucionais e legais de obtenção de prova, para evitar questionamentos acerca da sua licitude e do seu valor. De maneira simplificada: enquanto na investigação pública o defensor é mero coadjuvante, na investigação defensiva ele assume o papel de protagonista.

Por isso, a investigação defensiva permite uma participação muito mais abrangente e efetiva da defesa, em prol do imputado, do que a simples intervenção na investigação pública.

Nessa trilha, bem de se ver que alguns ordenamentos jurídicos estrangeiros previram a investigação defensiva. Em realidade, cuida-se de prática antiga e usual do

\footnotetext{
${ }^{91}$ LOPES Jr., Aury, Sistemas..., p. 96.

${ }^{92}$ ALMEIDA, Joaquim Canuto Mendes de, Princípios..., p. 117; e SCARANCE FERNANDES, Antonio, Processo..., pp. 64/65.
} 
Direito norte-americano, o qual, por observar um modelo processual penal "adversarial", concedeu às partes iniciativa probatória e investigatória. Já nos países de cultura jurídica romano-germânica, a investigação defensiva é vista com maiores ressalvas. Até o momento, apenas a Itália, por meio da Lei n. ${ }^{\circ}$ 397, de 07 de dezembro de 2000, incorporou e regulamentou esse tipo de procedimento investigatório.

A partir da análise do Direito italiano, André Boiani e Azevedo e Édson Luís Baldan definiram investigação defensiva como “o complexo de atividades de natureza investigatória desenvolvido, em qualquer fase da persecução criminal, inclusive na antejudicial, pelo defensor, com ou sem assistência de consulente técnico e/ou investigador privado autorizado, tendente à coleta de elementos objetivos, subjetivos e documentais de convicção, no escopo de construção de acervo probatório lícito que, no gozo da parcialidade constitucional deferida, empregará para pleno exercício da ampla defesa do imputado em contraponto à investigação ou acusações oficiais”. ${ }^{93}$

Do conceito supra-transcrito, extraem-se os requisitos essenciais da investigação defensiva, quais sejam: (i) prática de atos de investigação (e não de prova); (ii) pelo defensor do imputado, com ou sem o apoio de auxiliares técnicos; (iii) em qualquer momento da persecução penal; (iv) fora dos autos da investigação pública e como contraponto a esta; (v) com o objetivo de reunir elementos de convicção lícitos e relevantes para a defesa do imputado.

Por fim, a investigação defensiva, por ser espécie de investigação privada, não goza de imperatividade. Ou seja, o defensor não tem poderes coercitivos no exercício de suas atividades investigatórias e, por isso, depende do consentimento do titular do direito para obter determinada informação. Caso encontre algum obstáculo para a apuração dos fatos, deve recorrer à Autoridade Judiciária.

Os aspectos gerais da investigação defensiva, ora delineados, serão examinados, oportunamente e com a devida atenção, nos capítulos seguintes.

93 "A preservação do devido processo legal pela investigação defensiva (ou do direito de defender-se provando” in Boletim do Instituto Brasileiro de Ciências Criminais, n. . 137, abril/2004, p. 07. 


\section{O MODELO INVESTIGATÓRIO BRASILEIRO: O INQUÉRITO POLICIAL}

\section{III.1. O panorama histórico da investigação criminal no Direito brasileiro}

Desde o seu primórdio, o Direito brasileiro sempre previu alguma forma de investigação preliminar de infrações penais, isto é, um procedimento prévio à fase judicial, destinado a reunir elementos atinentes à possível conduta criminosa e verificar a viabilidade de eventual juízo acusatório.

Na época do Brasil colonial, durante a vigência das Ordenações, existiam duas formas de investigação criminal: a devassa e a querela. A primeira era uma inquirição ordinária, sem preliminar indicação de autoria ou de indícios; a segunda era uma inquirição sumária, com indicação prévia de autoria ou de indícios. ${ }^{94}$

A legislação e os costumes portugueses guiaram o rumo da investigação criminal no Brasil até a sua independência, em 07 de setembro de 1822. A Constituição de 25 de março de 1824 instituiu os Juizados de Paz, regulamentados por lei específica que conferiu aos Juízes de Paz atribuições policiais preventivas e repressivas. Tais poderes foram mantidos pelo Código de Processo Criminal promulgado em 29 de novembro de 1832. ${ }^{95}$

Apenas com a Lei n. ${ }^{0}$ 261, de 03 de dezembro de 1841, é que a investigação criminal passou a ser conduzida pela Autoridade Policial. De fato, o artigo $4^{\circ}$, $\S 9^{\circ}$, deste diploma legal, conferia aos Delegados de Polícia as atribuições de "remeter, quando julgarem conveniente, todos os dados, provas e esclarecimentos que houverem obtido sobre um delito, com a exposição do caso e suas circunstâncias, aos juízes competentes para a formação da culpa”. ${ }^{96}$

Posteriormente, foi editada a Lei n. ${ }^{0}$ 2.033, de 20 de setembro de 1871, que procurou reparar uma falha do estatuto anterior, consistente na discricionariedade da

\footnotetext{
${ }^{94}$ Ver ALMEIDA, Joaquim Canuto Mendes de, Princípios..., pp. 195/97.

${ }^{95}$ Marta Saad descreve detalhadamente as atribuições dos Juízes de Paz e o modelo de investigação criminal adotado nessa época ( $O$ direito de defesa..., pp. 27/40).

${ }^{96}$ O Regulamento 120/1842 estabeleceu a divisão funcional da Polícia em Administrativa e Judiciária, incumbindo a esta a tarefa de proceder ao corpo de delito, expedir mandado de busca e apreensão, prender denunciados e julgar crimes de sua alçada.
} 
Autoridade Policial para enviar ao Juiz competente os elementos informativos referentes a um possível delito.

A Lei n. ${ }^{\circ}$ 2.033, de 1871, foi regulamentada pelo Decreto $n .^{\circ} 4.824$, de 22 de novembro de 1871, que consagrou a figura do inquérito policial como forma de persecução prévia. ${ }^{97}$ Tal Lei, em seu artigo 42, definia o inquérito policial como "todas as diligências necessárias para o descobrimento dos fatos criminosos, de suas circunstâncias, e dos seus autores e cúmplices". 98

De acordo com a maior parte da doutrina nacional, o inquérito policial foi criado pelo Decreto n. ${ }^{\circ}$ 4.824, de 1871. Diverge dessa orientação João Mendes de Almeida Jr., para quem o inquérito policial dataria de período anterior e apenas teria sido regulamentado com o aludido Decreto. ${ }^{99}$

O inquérito policial, desde a sua positivação inaugural no Direito brasileiro na segunda metade do século XIX, continua a ser o principal modelo legal de apuração de fatos criminosos.

Em 1936, durante a gestão de Vicente Raó no Ministério da Justiça, por ocasião dos debates para a elaboração do Anteprojeto do atual Código de Processo Penal de 1941, chegou a ser proposta a substituição do inquérito policial pelo juizado de instrução.

${ }^{97}$ Conforme Antonio Scarance Fernandes, “a estruturação do inquérito em 1871 resultou de uma preocupação garantista, pois teve como objetivo coibir abusos na atuação das autoridades policiais, que, em virtude da Lei de 3 de dezembro de 1841 e do Regulamento 120, de 31 de janeiro de 1842, detinham excessivos poderes no sistema processual penal brasileiro. Não havia fixação de tempo para a autoridade policial remeter aos juízes os dados e esclarecimentos obtidos, a fim de que se procedesse à formação de culpa. A polícia realizava autênticas devassas. O inquérito policial teve como escopo conter os abusos, fixando-se prazo para o encerramento das investigações; assim, se o investigado estivesse preso, o inquérito deveria ser ultimado em cinco dias” (Teoria Geral..., p. 92).

${ }^{98}$ A respeito da reforma de 1871, disserta Marta Saad: “A reforma de 1871 transformou a feição do sumário de culpa, com a mudança da circunscrição judiciária do distrito policial para o termo, atribuindo a atividade das autoridades policiais aos juízes municipais ou aos juízes de direito, no caso das capitais que fossem sede da Relação e nas comarcas a elas ligadas. Assim, também a atribuição de formação da culpa passou aos juízes municipais e aos juízes de direito, devendo ser exercida na comarca, em vez do distrito de paz ou policial, e as autoridades policiais deixaram de pronunciar, como antes faziam.

Contudo, diante da necessidade de se colherem as provas tão logo se tivesse notícia dos delitos, determinadas atribuições foram ressalvadas às autoridades policiais, especificadas no art. 10 da Lei 2.033/1871 e pormenorizadas nos arts. 38 e 45 do Decreto 4.824/1871, acabando por consagrar o inquérito policial” ( $O$ direito de defesa..., pp. 51/52).

${ }^{99}$ MENDES DE ALMEIDA Jr., João, O processo..., p. 237. 
No entanto, esta sugestão não vingou e manteve-se o inquérito policial como instrumento investigatório de infrações penais, pois, segundo o legislador da época, era o modelo mais adequado para a realidade brasileira. Primeiro, em razão das dimensões continentais do país, o que dificultaria a atuação do Juiz instrutor. Segundo, porque evitaria juízos prematuros sobre a prática delitiva. ${ }^{100}$

Hoje, o inquérito policial está regulado nos artigos $4^{\circ}$ a 23 do Código de Processo Penal (Decreto-Lei n. ${ }^{\circ}$ 3.689, de 03 de outubro de 1941). ${ }^{101}$ Importante observar que tais normas surgiram em pleno regime ditatorial, no qual se defendia a eficiência da persecução criminal a todo o custo e o imputado era tratado como mero objeto da investigação.

Por tal motivo, toda a sistemática legal do inquérito policial, como se examinará adiante, deve ser interpretada em harmonia com a Constituição da República de 1988, de inspiração liberal e garantista.

\section{III.2. Conceito e natureza jurídica do inquérito policial.}

O ordenamento jurídico brasileiro prevê o inquérito policial como principal modelo investigatório de fatos potencialmente criminosos. Além deste, existe o inquérito militar, que averigua infrações penais de competência da Justiça Militar, em regra, aquelas

\footnotetext{
${ }^{100}$ Vale conferir trechos da exposição de motivos ao Código de Processo Penal, subscrita por Francisco Campos, Ministro da Justiça à época, verbis: "Foi mantido o inquérito policial como processo preliminar ou preparatório da ação penal, guardadas as suas características atuais. O ponderado exame da realidade brasileira, que não é apenas a dos centros urbanos, senão também a dos remotos distritos das comarcas do interior, desaconselha o repúdio do sistema vigente. O preconizado juízo de instrução, que importaria limitar a função da autoridade policial a prender criminosos, averiguar a materialidade dos crimes e indicar testemunhas, só é praticável sob a condição de que as distâncias dentro do seu território de jurisdição sejam fácil e rapidamente superáveis. Para atuar proficuamente em comarcas extensas, e posto que deva ser excluída a hipótese de criação de juizados de instrução em cada sede do distrito, seria preciso que o juiz instrutor possuísse o dom da ubiqüidade. (...) há em favor do inquérito policial como instrução provisória antecedendo à propositura da ação penal, um argumento dificilmente contestável: é ele uma garantia contra apressados e errôneos juízos, formados quando ainda persiste a trepidação moral causada pelo crime ou antes que seja possível uma exata visão de conjunto dos fatos, nas suas circunstâncias objetivas e subjetivas" (Exposição de Motivos ao Código de Processo Penal de 1941).

${ }^{101}$ Salienta Marta Saad, referindo-se ao magistério de Joaquim Canuto Mendes de Almeida, que o atual Código de Processo Penal extinguiu o sumário de culpa nos processos de competência do Juiz singular. Assim, o inquérito policial tornou-se o único fundamento para a acusação, assumindo uma função de instrução preliminar (O direito de defesa..., p. 77).
} 
praticadas por componentes de alguma corporação militar, ou mesmo por civil, contra aquelas organizações em área sob sua segurança direta.

Aventa-se, ainda, a formação judicial do corpo de delito para os crimes contra a propriedade imaterial, conforme procedimento especial previsto nos artigos 525 e seguintes do Código de Processo Penal. ${ }^{102}$

Sinteticamente, é possível definir o inquérito policial como “atuação investigatória da Polícia Judiciária, com a finalidade de apurar a materialidade da infração penal cometida e respectiva autoria”. 103

De maneira mais detalhada, Sérgio Marcos de Moraes Pitombo ${ }^{104}$ conceituou o inquérito policial como procedimento cautelar, de natureza administrativa, quanto à forma, e judiciária, quanto à finalidade, por meio do qual se ultima investigação acerca da materialidade e autoria de fato supostamente criminoso.

Em primeiro lugar, entende-se que o inquérito policial é procedimento - e não processo - por não haver contraditoriedade perfeita na seqüência dos atos. Ademais, é procedimento formal, pois devem ser observadas algumas regras na realização de cada ato e existe uma ordem para início (portaria ou auto de flagrante da Autoridade Policial, requisição do Juiz ou do Ministério Público, ou requerimento do ofendido ou de seu

${ }^{102}$ Existem outras formas de investigação para ilícitos não penais:

(i) inquérito parlamentar - investigações conduzidas pelas Comissões Parlamentares de Inquérito, cujos poderes estão fixados no artigo 58, $\S 3^{\circ}$, da Constituição da República. Tais comissões são regulamentadas pela Lei n. ${ }^{\circ} 1.579$, de 18 de março de 1952, e Lei n. ${ }^{\circ} 10.001$, de 08 de maio de 2000, e pelos Regimentos Internos da Câmara dos Deputados e do Senado Federal; (ii) inquérito civil - procedimento administrativo não disciplinar, presidido pelo Ministério Público, previsto no artigo $8^{\circ}, \S 1^{\circ}$, da Lei.$^{\circ}{ }^{7} .347$, de 24 de julho de 1985, cuja finalidade é identificar violação a bens de interesse público e, se for o caso, embasar Ação Civil Pública; (iii) inquérito administrativo em sentido estrito ou sindicância - procedimento administrativo disciplinar, que apura responsabilidade de funcionários ou servidores públicos por conta de um ilícito administrativo; (iv) inquérito judicial trabalhista - procedimento previsto no artigo 494 da Consolidação das Leis do Trabalho, para averiguar falta grave cometida por empregados com mais de 10 anos de serviço na mesma empresa, sem o qual não poderá ser dispensado. Por fim, até recentemente, existia o inquérito judicial falimentar, regulado nos artigos 103 e seguintes do Decreto-Lei n. ${ }^{\circ}$ 7.661, de 21 de junho de 1945, e artigo 509 do Código de Processo Penal. Tal investigação era realizada pela Autoridade Judiciária. No Estado de São Paulo, por força da Lei n. ${ }^{\circ}$ 3.947/83, o Juiz da Vara de Falências era o competente para efetuar a investigação e, se fosse o caso, julgar a ação penal por crime falimentar. Todavia, essa modalidade de investigação criminal foi abolida pela Lei n. ${ }^{\circ}$ 11.101, de 09 de fevereiro de 2005 (nova Lei de Falências). Atualmente, se existir prova da ocorrência de crime falimentar, o Ministério Público deve apresentar denúncia, se possuir elementos para tanto, ou requisitar a instauração de inquérito policial, nos termos do artigo 187, caput, da Lei n. ${ }^{\circ} 11.101 / 05$.

${ }^{103}$ TUCCI, Rogério Lauria, Persecução penal..., p. 43.

${ }^{104}$ Inquérito..., p. 15. 
representante), desenvolvendo-se com as demais diligências que se fizerem necessárias e encerrando-se com um relatório final. ${ }^{105}$

Ao revés, Antonio Scarance Fernandes ${ }^{106}$ entende que o inquérito policial não chega a ser procedimento, pois lhe faltaria requisito essencial do procedimento, qual seja, a formação por atos que obedeçam a seqüência predeterminada por lei.

A nosso ver, o inquérito policial pode ser considerado procedimento, pois, apesar de inexistir ordem legal rígida para a realização dos atos, o legislador estabeleceu uma seqüência lógica para a instauração, desenvolvimento e conclusão deste procedimento investigatório, como se verificará adiante. ${ }^{107}$

Por outro lado, falta ao inquérito policial a contraditoriedade - elemento essencial para a caracterização da relação jurídico-processual - razão pela qual não pode ser considerado processo.

Em segundo lugar, o inquérito policial é procedimento cautelar pré-processual, pois serve para a captação e preservação de meios de prova da materialidade e da autoria delitiva, a serviço de eventual ação penal e é preliminar ao processo, embasando a sua instauração ou impedindo acusações descabidas. ${ }^{108}$

José Frederico Marques destaca a cautelaridade do inquérito policial, verbis: “a investigação não passa do exercício do poder cautelar que o Estado exerce, através da polícia, na luta contra o crime, para preparar a ação penal e impedir que se percam os elementos de convicção sobre o delito cometido", ${ }^{109}$

Por conta dessa natureza cautelar, a investigação policial deve ocorrer imediatamente após o conhecimento da notícia de crime, para evitar o perecimento dos elementos de convicção relacionados ao possível delito.

\footnotetext{
${ }^{105}$ MORAES, Bismael B., Direito e Polícia..., p. 122; e MEHMERI, Adilson, Inquérito Policial..., p. 16.

${ }^{106}$ Processo..., p. 64.

${ }^{107}$ Marta Saad entende que o inquérito policial é procedimento, pois deve “ostentar perfeição lógica e formal, visto que determinadas formalidades, em especial do auto de prisão em flagrante delito, devem ser obedecidas, a fim de salvaguardar os direitos e garantias individuais". E mais: "O procedimento do inquérito policial, por sua própria natureza, é e precisa ser flexível. Não obedece a uma ordem determinada, rígida, de atos, mas, nem por isso, deixa o inquérito de ser procedimento, visto que o procedimento pode seguir esquema rígido ou flexível” (SAAD, Marta, $O$ direito de defesa..., pp. 246/47).

${ }^{108}$ PITOMBO, Sérgio Marcos de Moraes, Inquérito..., p. 16.

${ }^{109}$ Elementos..., p. 145.
} 
Importante perceber que “a cautelaridade ínsita aos atos do inquérito não se confunde com provisoriedade, visto que muitos dos atos acabam transcendendo essa possível característica, convertendo-se de provisórios em permanentes”. ${ }^{110}$

Em terceiro lugar, sob uma ótica formal, o inquérito policial é procedimento administrativo, porque dirigido pela Polícia Judiciária, ente estatal integrante da Administração Pública, vinculado ao Poder Executivo, que pratica atos de caráter administrativo. $^{111}$

Por outro viés, considerando a finalidade dos atos desenvolvidos pela Polícia Judiciária, que objetivam à preliminar formação de culpa, o inquérito policial deve ser qualificado como judiciário.

Nessa linha, ressalta Sérgio Marcos de Moraes Pitombo que “no procedimento do inquérito, encontra-se, portanto, conjunto de atos de instrução; transitórios uns, de relativo efeito probatório e definitivos outros, de efeito judiciário absoluto. Melhor, pois, afirmar que a polícia, enquanto judiciária e o inquérito, que ela faz, exsurgem administrativos, por sua atuação e forma, mas judiciários, nos seus fins”. 112

\footnotetext{
${ }^{110}$ SAAD, Marta, O direito de defesa..., p. 149.

${ }^{111}$ Sérgio Marcos de Moraes Pitombo esclarece que "a Polícia, em palavras simples, consiste em órgão da administração direta, voltado à segurança pública. Quando atua como integrante da Justiça Penal, se diz que a polícia é judiciária” (Inquérito..., p. 16). O artigo 144, $\S 1^{\circ}$, incisos I e IV, e $\S 4^{\circ}$, da Constituição da República, confere às Polícias Federal e Estadual as funções de Polícia Judiciária e apuração de infrações penais, exceto as militares. Em nível infraconstitucional, tal atribuição está prevista no artigo $4^{\circ}$, caput, do Código de Processo Penal.

112 Inquérito..., p. 22. No mesmo sentido: TUCCI, Rogério Lauria, Direitos e garantias..., p. 15 e MEHMERI, Adilson, Inquérito Policial..., p. 13. Sérgio Marcos de Moraes Pitombo salienta que, no inquérito policial, há atos processuais, praticados por delegação, e nele existe contingente instrução criminal definitiva. Por isso, segundo o autor, o inquérito policial não é mero procedimento administrativo. In verbis: "Dizer-se, por isso, que o inquérito policial consiste em mero procedimento administrativo e encerra investigação administrativa, é simplificar, ao excesso, a realidade sensível. Resta-se na necessidade esforçada de asseverar, em seguida, que a decisão judicial, que recebe a denúncia ou a queixa, embasada em inquérito, volta no tempo e no espaço, judicializando alguns atos de procedimento” (Inquérito..., p. 21). Já Bismael B. Moraes entende que o inquérito policial não pode ser taxado simplesmente como procedimento administrativo, pois inúmeros atos produzidos nessa fase têm validade jurídico-processual. Para esse autor, o inquérito policial seria procedimento extrajudicial, de natureza processual, pelo fato de estar inserido no Código de Processo Penal - entendimento do qual discordamos, pois falta ao inquérito policial o contraditório, requisito essencial para qualificá-lo como processual. Diz o jurista, a respeito da natureza jurídica do inquérito policial, que "se não o quisermos sentir como procedimento híbrido, composto por atos de ordem administrativa e atos de valor processual definitivo, não podemos negar que o inquérito policial seja um procedimento extrajudicial, de natureza processual, de vez que inserido no Código de Processo Penal e realizado pela Polícia Judiciária” (MORAES, Bismael B., Direito e Polícia..., p. 135).
} 


\section{III.3. A apuração sumária dos fatos no âmbito do inquérito policial}

O inquérito policial começa com mero juízo de possibilidade a respeito da imputação constante da notícia de crime. Para o início da persecução penal, "não é preciso que o crime se apresente na integridade de seus elementos constitutivos. Desde que uma conduta comissiva ou omissiva possa enquadrar-se em tipo abstrato descrito na lei penal, torna-se ela relevante para a atividade persecutória do Estado. Basta, por isso, à autoridade policial a notícia de um fato típico, para que inicie as investigações em que se corporifica o momento inicial da persecutio criminis". ${ }^{113}$

Durante a persecução prévia, são reunidos novos dados que podem levar a um juízo de probabilidade acerca da infração penal, necessário para formular a acusação ou aplicar medidas cautelares. Ao revés, se o juízo sobre a imputação permanecer no limite do possível, o feito deve ser arquivado. ${ }^{114}$

Logo, o inquérito policial, enquanto espécie de investigação criminal, deve se pautar por uma cognição sumária dos fatos aduzidos na notícia de crime, com a finalidade de atestar o fumus commissi delicti. É inadmissível um exame aprofundado dos fatos investigados para se atingir um grau de certeza a respeito da imputação, pois esse nível de cognição está reservado ao processo, no momento em que houver a prolação da sentença.

Para garantir a sumariedade da cognição no inquérito policial, a legislação brasileira prevê uma limitação qualitativa e outra quantitativa. A primeira, prevista no artigo $4^{\circ}$, caput, do Código de Processo Penal, é de ordem material, circunscrevendo o inquérito policial à apuração de infrações penais e sua autoria.

Não obstante a falta de clareza da lei sobre a profundidade dessa apuração, é evidente que o inquérito policial deve averiguar a provável ocorrência do fato criminoso e sua autoria, em virtude da sua própria natureza de instrução prévia e não definitiva.

\footnotetext{
113 MARQUES, José Frederico, Elementos..., pp. 129/30.

${ }^{114}$ Nesse sentido, veja-se o magistério de Aury Lopes Jr.: “É importante recordar que, para a instauração do inquérito policial, basta a mera possibilidade de que exista um fato punível. A própria autoria não necessita ser conhecida no início da investigação. Sem embargo, para o exercício da ação penal e a sua admissibilidade, deve existir um maior grau de conhecimento: exige-se a probabilidade de que o acusado seja autor (co-autor ou partícipe) de um fato aparentemente punível” (Sistemas..., p. 176).
} 
O Projeto de Lei n. ${ }^{0}$ 4.209/01, relativo à investigação criminal, que se encontra em tramitação no Congresso Nacional, veio suprir a deficiência existente na legislação processual penal e regulou claramente o grau de cognição do inquérito policial.

Segundo a nova redação prevista para o artigo $7^{\circ}$, caput, do Código de Processo Penal, “os elementos informativos da investigação deverão ser colhidos na medida estritamente necessária à formação do convencimento do Ministério Público ou do querelante sobre a viabilidade da acusação, bem como à efetivação de medidas cautelares, pessoais ou reais, a serem autorizadas pelo juiz”. Além disso, o parágrafo único do mesmo dispositivo estabelece que "esses elementos não poderão constituir fundamento da sentença, ressalvadas as provas produzidas cautelarmente ou irrepetíveis, que serão submetidas a posterior contraditório”.

A limitação quantitativa, por sua vez, está relacionada à fixação de prazo para o término do inquérito policial. Como regra geral, o artigo 10 do Código de Processo Penal prevê o prazo de 10 (dez) dias para o término do inquérito policial, se o indiciado estiver preso preventivamente, e de 30 (trinta) dias se estiver solto.

Existem também normas específicas sobre a limitação temporal do inquérito policial. O artigo 66, caput, da Lei n. ${ }^{\circ}$ 5.010/66, aplicável aos inquéritos policiais de competência da Justiça Federal, estabelece o prazo de 15 (quinze) dias para conclusão da investigação, se o imputado estiver preso, que pode ser prorrogado por igual período.

Além disso, o artigo 51 da Lei n. ${ }^{\circ}$ 11.343/06 (Lei de Entorpecentes) prevê o prazo de 30 (trinta) dias para o término da persecução prévia, se o imputado estiver preso, e de 90 (noventa) dias se estiver solto. Tais prazos podem ser duplicados pelo Juiz, após ouvir o Ministério Público, mediante pedido justificado da Autoridade Policial.

Vislumbra-se, ainda, controle temporal atípico sobre o prazo das investigações, consistente na hipótese de reconhecimento da prescrição retroativa, conforme previsto no artigo 110, §2º do Código Penal.

Entretanto, o que se pode constatar, na prática, é que as mencionadas restrições legais são ineficazes e os inquéritos policiais perduram por meses e até anos. ${ }^{115} \mathrm{Um}$ dos

${ }^{115}$ Em crítica ao modelo brasileiro de controle temporal das investigações, afirma Fauzi Hassan Choukr que “a ausência de barreira cronológica fomenta o desaparelhamento do Estado e o despreparo dos profissionais 
fatores para essa absurda situação é a faculdade prevista no artigo 10, §3º , do Código de Processo Penal, que permite à Autoridade Policial solicitar ao Juiz a devolução dos autos, para ulteriores diligências, quando o fato for de difícil elucidação e o imputado estiver solto.

A aludida norma acaba por respaldar prorrogações injustificáveis no andamento do inquérito policial. Soma-se a isso a praxe policial - que conta com a anuência e até mesmo colaboração de Juízes e Promotores - de converter o inquérito policial em fase de instrução definitiva, desfigurando a sua verdadeira natureza de investigação preliminar cujo objetivo é a apuração sumária dos fatos constantes da notícia de crime. $^{116}$

\section{III.4. Eficácia probatória do inquérito policial}

O inquérito policial, como visto, destina-se a colher elementos de convicção acerca de uma prática delitiva, que servem para fundamentar as decisões interlocutórias proferidas nessa fase, bem como justificar eventual ação penal ou arquivamento do feito.

Assim, é equivocado o entendimento difundido na doutrina pátria de que o inquérito policial seria base apenas para a acusação, uma vez que ampara também o juízo do órgão ministerial e da Autoridade Judiciária a respeito do arquivamento. ${ }^{117}$

que lidam com a matéria que, desobrigados a controlar sua atividade no tempo, não se inibem em propugnar prazos meramente dilatórios, no que são passivamente correspondidos pelos outros agentes da justiça criminal” (CHOUKR, Fauzi Hassan, Garantias Constitucionais..., p. 160).

${ }^{116}$ Nesse sentido, reza Aury Lopes Jr.: "Uma das maiores críticas que se faz ao IP é a repetição na produção da prova. O inquérito policial é normativamente sumário, inclusive com limitação quantitativa ou temporal, mas o que sucede na prática é que ele se transforma de fato em plenário. Esta conversão - de normativamente sumário em efetivamente plenário - é uma gravíssima degeneração. A polícia demora excessivamente a investigar, investiga mal e, por atuar mal, acaba por alongar excessivamente a investigação. O resultado final é um inquérito inchado, com atos que somente deveriam ser produzidos em juízo, e que por isso desborda os limites que o justificam” (Sistemas..., p. 177).

117 “O inquérito policial não é só base para a acusação, como a maioria dos autores costuma dizer, mas base para o arquivamento, quando se constata que os meios de prova lá constantes são falhos quanto ao fato e/ou à autoria, ou porque os meios de prova demonstram que o fato apurado é inexistente ou atípico, ou, ainda, comprovam a existência de causa de exclusão da antijuridicidade ou causa de extinção da punibilidade” (SAAD, Marta, $O$ direito de defesa..., pp. 150/51). 
De outra parte, costuma-se ressaltar o valor informativo do inquérito policial, o qual, como instrução provisória, forneceria elementos ao titular da ação penal para formar a sua opinio delicti e o guiar durante a fase judicial. ${ }^{118}$

Ao mesmo tempo, defende-se que, conforme as circunstâncias do caso, o Juiz poderia invocar os elementos oriundos da investigação preliminar para reforçar as provas apuradas judicialmente e, com isso, fundamentar a sentença. ${ }^{119}$

Tal orientação - não obstante seja contraditória e destoe da própria natureza jurídica do inquérito policial - acabou sendo absorvida pelos Tribunais pátrios. Segundo o posicionamento jurisprudencial majoritário, é possível à utilização dos dados oriundos do inquérito policial para embasar a condenação, desde que não sejam os únicos elementos de prova a formar o convencimento judicial. ${ }^{120}$

Por outro lado, incoerentemente, sustenta-se que eventuais vícios existentes na instrução prévia não contaminariam a ação penal, pois o inquérito policial seria peça simplesmente informativa e não probatória. ${ }^{121}$

Ora, tais linhas argumentativas são inconciliáveis. Se os elementos probatórios decorrentes do inquérito policial são aproveitados na ação penal, ele deixa de ser apenas informativo e as irregularidades porventura existentes na fase preliminar maculam também o processo.

\footnotetext{
${ }^{118}$ MARQUES, José Frederico, Elementos..., p. 154. Esse valor meramente informativo do inquérito policial, como explicitado anteriormente, é questionado por alguns doutrinadores: conferir ALMEIDA, Joaquim Canuto Mendes de, Princípios..., pp. 07/10; PITOMBO, Sérgio Marcos de Moraes, Inquérito..., p. 22; e SAAD, Marta, O direito de defesa..., pp. 159/61. Paulo Cláudio Tovo ressalta que o inquérito policial possui valor meramente informativo apenas no tocante às provas renováveis ou repetíveis, a fim de se evitar dupla instrução (uma provisória e outra definitiva). De outra parte, existem elementos de convicção já prontos nos autos do inquérito policial, que possuem valor probatório e devem ser levados em consideração pelo Juiz na fase processual, principalmente se dizem respeito à comprovação da inocência do acusado ("O inquérito policial em sua verdadeira dimensão" in Estudos de Direito Processual Penal. TOVO, Paulo Cláudio (org.). Porto Alegre: Livraria do Advogado, 1995, p. 148).

${ }^{119}$ MARQUES, José Frederico, Elementos..., pp. 154/55.

${ }^{120}$ Nesse sentido: STF, RE-AgR n. ${ }^{\circ}$ 425.734/MG, Rel. ${ }^{a}$ Min. ${ }^{a}$ Ellen Gracie, j. 04.10.2005; STF, HC n. ${ }^{\circ}$ 83.348/SP, Rel. Min. Joaquim Barbosa, j. 21.10.2003; STF, HC n. ${ }^{\circ}$ 82.622/SP, Rel. Min. Carlos Velloso, j. 08.04.2003; STF, HC n. ${ }^{\circ}$ 73.513/SP, Rel. Min. Moreira Alves, j. 26.03.1996 in RT 740/527; STJ, HC n. ${ }^{\circ}$ 69.496/MS, Rel. ${ }^{a}$ Min. ${ }^{a}$ Jane Silva, j. 07.08.2007; STJ, HC n. ${ }^{0}$ 58.129/RJ, Rel. Min. Gilson Dipp, j. 17.10.2006; STJ, HC n. ${ }^{\circ}$ 32.226/SP, Rel. Min. Felix Fischer, j. 17.06.2004; TJSP, Ap. n. ${ }^{\circ}$ 181.308-3, Rel. Des. Silva Pinto, j. 08.05.1995 in RT 719/400; TJSP, Ap. n. ${ }^{\circ}$ 48.091-3, Rel. Des. Silva Leme, j. 29.06.1987 in RT 621/290.

${ }^{121}$ Nesse sentido: STF, RHC n. ${ }^{\circ}$ 85.286/SP, Rel. Min. Joaquim Barbosa, j. 29.11.2005; STF, HC n. ${ }^{\circ}$ 76.514/SP, Rel. Min. Moreira Alves, j. 10.03.1998; STJ, HC n. ${ }^{\circ}$ 47.960/RJ, Rel. ${ }^{a}$ Min. $^{a}$ Laurita Vaz, j. 08.11.2007; STJ, HC n. ${ }^{\circ}$ 39.767/GO, Rel. Min. Arnaldo Esteves Lima, j. 08.11.2005; STJ, HC n. ${ }^{\circ}$ 24.120/RJ, Rel. Min. Paulo Medina, j. 19.04.2005; STJ, HC n. ${ }^{\circ}$ 26.977/SP, Rel. Min. Jorge Scartezzini, j. 03.02.2004.
} 
Recentemente, foi promulgada a Lei n. $^{0}$ 11.690, de 09 de junho de 2008, que alterou a redação do artigo 155 do Código de Processo Penal e proibiu a formação do convencimento judicial apenas com os dados oriundos da investigação, excetuadas as provas cautelares, não repetíveis e antecipadas. ${ }^{122}$

A contrario sensu, permitiu-se a utilização dos atos de investigação na fase judicial, se não consistirem nos únicos elementos de convicção da Autoridade Judiciária. Tanto que a nova lei não previu a exclusão física do inquérito policial dos autos do processo. $^{123}$

O legislador desvirtuou o sentido do Projeto de Lei n. ${ }^{\circ} 4.205 / 01$, que resultou no diploma legal em comento. Tal Projeto vedava, completamente, a interferência da persecução prévia na formação do convencimento judicial, evitando a sua contaminação com os dados obtidos na fase investigatória. ${ }^{124}$

Contudo, a modificação legislativa mostrou-se contraproducente e, o que é pior, contrária às garantias constitucionais do devido processo legal, do contraditório e da ampla defesa, pois permitiu o aproveitamento dos atos de investigação no processo.

Nesse sentido, Marcos Alexandre Coelho Zilli, ao comentar a reforma legislativa, adverte que "a coesão de um modelo processual de partes foi comprometida. Isso porque a proibição total de inserção dos elementos informativos no campo cognitivo, desenhada pela proposta original da Comissão de Reforma, foi sensivelmente abrandada. Pela versão aprovada, fica o juiz autorizado a buscar naqueles elementos o reforço para certas provas produzidas em contraditório, confirmando assim a veracidade de uma das teses. Mais lógico seria que o conflito resultante de provas divergentes, não superável pela possibilidade de obtenção de novas provas, levasse à absolvição do acusado e não à invocação de elementos colhidos unilateralmente”. ${ }^{125}$

122 “Art. 155. O juiz formará sua convicção pela livre apreciação da prova produzida em contraditório judicial, não podendo fundamentar sua decisão exclusivamente nos elementos informativos colhidos na investigação, ressalvadas as provas cautelares, não repetíveis e antecipadas”.

${ }^{123}$ Permanece em vigor o artigo 12 do Código de Processo Penal, segundo o qual os autos do procedimento investigatório devem acompanhar a denúncia ou queixa, quando sirvam de base para estas.

${ }^{124}$ Antonio Magalhães Gomes Filho menciona a diferença de redação e de sentido entre o projeto original e o texto final da lei que alterou o artigo 155 do Código de Processo Penal ("Provas - Lei 11.690, de 09.06.2008” in As reformas no Processo Penal: as novas Leis de 2008 e os projetos de reforma. MOURA, Maria Thereza Rocha de Assis (org.). São Paulo: Revista dos Tribunais, 2008, p. 251).

125 “O Pomar e as Pragas”..., p. 02. Outros juristas também criticaram a reforma legislativa: Para Aury Lopes Jr., “o art. 155 não teve coragem para romper com a tradição brasileira de confundir atos de prova com atos 
Os dados provenientes do inquérito policial realmente não podem amparar a opinião do Magistrado na sentença, pois, como se viu, decorrem de atos de investigação, que não são produzidos em consonância com as garantias fundamentais da publicidade, do contraditório e da ampla defesa. Logo, deve haver a exclusão física desses elementos dos autos da ação penal e a sua renovação durante a instrução processual. ${ }^{126}$

Em caso de prova relevante e irrepetível, isto é, que por sua natureza não pode ser refeita na fase processual, deve-se realizar incidente de produção antecipada de provas. Por meio desta medida, há a jurisdicionalização da atividade probatória no curso do inquérito policial, que se efetua conforme as garantias processuais e resulta em verdadeiro ato de prova. ${ }^{127}$

\section{III.5. A estrutura legal do inquérito policial}

A legislação brasileira atinente ao inquérito policial, por ser fruto do regime autoritário de 1937 e inspirada pelo fascista “Código de Rocco”, deve ser objeto de

de investigação, com graves reflexos na eficácia probatória deles. A redação vai muito bem, até o ponto em que inseriram a palavra errada, no lugar errado. E uma palavra, faz muita diferença...Bastou incluir o ‘exclusivamente' para sepultar qualquer esperança de que os juízes parassem de condenar os réus com base nos atos do famigerado, inquisitório e superado inquérito policial. Seguiremos assistindo a sentenças que, negando a garantia de ser julgado a partir de atos de prova (realizados em pleno contraditório, por elementar), buscarão no inquérito policial (meros atos de investigação e sem legitimidade para tanto) os elementos (inquisitórios) necessários para a condenação)" ("Bom para quê(m)?) in Boletim do Instituto Brasileiro de Ciências Criminais, n. ${ }^{\circ}$ 188, julho/2008, p. 09). No mesmo sentido: PITOMBO, Cleunice Valentim Bastos. “Considerações iniciais sobre a Lei 11.690/08” in Boletim do Instituto Brasileiro de Ciências Criminais, n. ${ }^{\circ}$ 188, julho/2008, p. 20.

${ }^{126}$ Como assinala Fauzi Hassan Choukr, a separação física entre os autos da investigação e do processo é fundamental para impedir que os informes colhidos na persecução prévia sejam utilizados na fase judicial, verbis: "A repudiada influência em juízo dos informes colhidos nas investigações deve-se parcialmente, à inexistência de separação dos autos da investigação daqueles que formarão a ação penal (pode-se dizer que há uma comunhão de 'bases procedimentais' de um e outro momento). Com efeito, transpõe-se materialmente tudo aquilo que foi produzido na fase de preparação para os autos definitivos, e a intromissão, ainda que inconsciente, acaba acontecendo até pelo manuseio corriqueiro do processo. Se a cindibilidade física dos volumes não é, por si, a tábua de salvação do sistema, fato é que sua adoção ajudaria em muito, pelo menos na medida em que obrigaria o titular da ação a, jurisdicionalmente, produzir as provas necessárias para a comprovação da imputação criminosa dirigida ao acusado, não se servindo, com a largueza que hoje se encontra, da investigação para sustentar uma condenação" (Garantias..., pp. 138). No mesmo sentido: TOVO, Paulo Cláudio, “O inquérito policial em sua verdadeira dimensão”..., pp. 149/50.

127 O artigo 225 do Código de Processo Penal faz menção à produção antecipada de provas, verbis: "Se qualquer testemunha houver de ausentar-se, ou, por enfermidade ou por velhice, inspirar receio de que ao tempo da instrução criminal já não exista, o juiz poderá, de ofício ou a requerimento de qualquer das partes, tomar-lhe antecipadamente o depoimento". 
interpretação crítica e em harmonia com a Constituição da República de 1988. Com este enfoque é que se pretende abordar, a seguir, a disciplina legal do inquérito policial.

O inquérito policial tem início com a notícia de crime, isto é, o conhecimento espontâneo ou provocado de um fato delituoso pela autoridade pública. Será espontâneo, quando a autoridade tomar ciência da conduta criminosa diretamente. Será provocado, quando alguém comunicar a prática do fato delituoso à autoridade. ${ }^{128}$

Dispõe o artigo 5ª I e II, do Código de Processo Penal, que o inquérito policial pode ser instaurado de ofício pela Autoridade Policial; mediante requisição do Juiz ou do Ministério Público ${ }^{129}$ ou a requerimento do ofendido ou seu representante legal; ou, ainda, por comunicação verbal ou escrita de qualquer pessoa do povo em caso de delitos apurados mediante ação penal de iniciativa pública.

Segundo o $\S 3^{\circ}$ do referido dispositivo legal, qualquer pessoa que tiver conhecimento da existência de infração penal, em que caiba ação pública, pode comunicála à Autoridade Policial. Trata-se, portanto, de faculdade do cidadão e não de dever.

Excepcionalmente, a notícia de crime será obrigatória, como nos casos prescritos no artigo 66 do Decreto-Lei n. ${ }^{\circ}$ 3.688/41. De acordo com esse dispositivo, constitui contravenção penal deixar de comunicar à autoridade competente: (i) crime de ação pública, de que teve conhecimento no exercício de função pública, desde que a ação penal não dependa de representação; (ii) crime de ação pública, de que teve conhecimento no exercício de medicina ou de outra profissão sanitária, desde que a ação penal não dependa de representação e a comunicação não exponha o cliente a procedimento criminal.

De outra parte, as autoridades públicas envolvidas na persecução penal (Magistratura, Ministério Público e Polícia Judiciária) têm o dever de noticiar - e, no caso da Polícia Judiciária, investigar - fatos possivelmente criminosos, sob pena de responder administrativamente e de incorrer no delito de prevaricação previsto no artigo 319 do Código Penal.

\footnotetext{
${ }^{128}$ MARQUES, José Frederico, Elementos..., p. 132.

${ }^{129}$ Ao utilizar o vocábulo "requisição" o legislador vetou qualquer exame de mérito da Autoridade Policial sobre o pedido de instauração de inquérito policial feito pelo Juiz ou pelo Ministério Público. Situação diversa é a do ofendido ou de seu representante legal, que apenas podem "requerer” a instauração de inquérito policial, sujeitando-se ao crivo da Autoridade Policial.
} 
Por força do princípio da obrigatoriedade da ação penal, ${ }^{130}$ a Polícia Judiciária, ao tomar conhecimento de possível ilícito penal, deve iniciar e desenvolver a investigação preliminar, com a finalidade de esquadrinhar os fatos relacionados à prática delitiva. A esse respeito, disserta José Barcelos de Souza ${ }^{131}$ que o princípio da obrigatoriedade da ação penal estende-se à atividade investigatória da Polícia Judiciária, que é obrigada a efetivá-la nos termos da lei.

Não obstante, Carlos Laet de Souza afirma que a Autoridade Policial pode verificar a conveniência da instauração de inquérito policial. Segundo o autor, a Autoridade Policial deve efetuar triagem das ocorrências, por meio de uma "investigação extra-inquérito”, e instaurar o inquérito policial apenas se as informações forem procedentes. $^{132}$

Esta posição é insustentável, pois a “investigação extra-inquérito" confere excessivo poder discricionário à Polícia Judiciária, dando margem a toda sorte de abusos e arbitrariedades. Lembra Marta Saad ${ }^{133}$ que há discussão na doutrina sobre esta atividade discricionária da Autoridade Policial, sendo que muitos autores propugnam a ilegalidade destas investigações preliminares antes da instauração de inquérito.

Se a notícia de crime possuir indícios suficientes acerca de possível infração penal, deve necessariamente haver a formalização de inquérito policial devido ao princípio da obrigatoriedade da ação penal. De outra parte, se for totalmente descabida, sem respaldo jurídico ou material - o que muitas vezes sói acontecer, principalmente em caso de denúncia anônima -, a Autoridade Policial não deve realizar “investigação extrainquérito”, mas sim arquivar a notícia de crime. ${ }^{134}$

\footnotetext{
${ }^{130}$ Luigi Ferrajoli define tal postulado como "a obrigação dos órgãos da acusação pública de promover o juízo para toda notitia criminis que vier a seu conhecimento - ainda que para requerer o arquivamento ou a absolvição caso considerem o fato penalmente irrelevante ou faltarem indícios de culpabilidade" (Direito $e$ razão..., p. 457).

${ }^{131}$ SOUZA, José Barcelos de. Teoria e prática da ação penal. São Paulo: Saraiva, 1979, p. 30. Ver, também, TUCCI, Rogério Lauria, Persecução penal..., p. 19 e 23.

132 "Da investigação policial e da instrução criminal provisória" in Revista Brasileira de Ciências Criminais, n. ${ }^{\circ} 21$, jan./mar. de 1998, p. 160.

133 O direito de defesa..., p. 144.

${ }^{134}$ Tal determinação consta da Portaria n. ${ }^{\circ}$ 18, de 25 de novembro de 1998, exarada pela Delegacia Geral de Polícia do Estado de São Paulo, verbis: “Art. $2^{\circ}$ - A autoridade policial não instaurará inquérito quando os fatos levados à sua consideração não configurarem, manifestamente, qualquer ilícito penal.

$\S 1^{\circ}$ - Igual procedimento adotará, em face de qualquer hipótese determinante de falta de justa causa para a deflagração da investigação criminal, devendo, em ato fundamentado, indicar as razões jurídicas e fáticas de seu convencimento.
} 
Nos crimes apurados mediante ação penal pública condicionada, o inquérito policial depende de regular representação da vítima, por força do disposto no artigo $5^{\circ}, \S 4^{\circ}$, do Código de Processo Penal. Já nos delitos de ação penal de iniciativa privada, a instauração de procedimento investigatório depende de requerimento do ofendido ou de seu representante legal, conforme preceitua o artigo 5 $5^{\circ} 5^{\circ}$, da Lei Adjetiva Penal.

De acordo com o artigo 5, §1, alíneas “a”, “b” e “c”, do Código de Processo Penal, o requerimento do ofendido deve conter a narração do fato, com todas as circunstâncias, dados sobre a autoria e a indicação de testemunhas.

O artigo $6^{\circ}$ do Código de Processo Penal especifica as funções da Autoridade Policial, que, em síntese, deve colher todos os elementos informativos que interessem à elucidação do fato e suas circunstâncias.

Admite-se, ainda, a requisição de diligências por parte do Juiz ou do Ministério Público; ou a requerimento do ofendido, de seu representante legal ou do indiciado (artigos 13, II, e 14 do Código de Processo Penal). ${ }^{135}$ Infere-se do texto legal que, no primeiro caso, o Delegado de Polícia teria o dever de acatar as providências requisitadas, enquanto no segundo haveria mera faculdade, pois a realização da diligência ficaria a seu critério. Contudo, tal interpretação não se coaduna com uma leitura constitucional da norma processual, como se evidenciará adiante.

Concluídas as investigações, a Autoridade Policial deve elaborar minucioso relatório com os dados levantados e enviar os autos ao Juiz, conforme prevê o artigo 10, $\S 1^{\circ}$, do Código de Processo Penal.

Em hipótese nenhuma, a Autoridade Policial pode determinar o arquivamento do feito ou interromper as investigações inconclusas, em razão do disposto no artigo 17 do

$\S 2^{\circ}$ - Quando a notícia do suposto ilícito penal chegar ao conhecimento de autoridade policial por meio de requerimento (art. 5º, II, Código de Processo Penal), esta, em despacho motivado, não conhecerá do pedido, se ausente descrição razoável da conduta a ensejar classificação em alguma infração penal ou indicação de elementos mínimos de informação e de prova que possibilitem o desenvolvimento de investigação".

${ }^{135}$ Artigo 13, II, do Código de Processo Penal: "Incumbirá ainda à autoridade policial: (...) II - realizar as diligências requisitadas pelo juiz ou pelo Ministério Público".

Artigo 14 do Código de Processo Penal: "O ofendido, ou seu representante legal, e o indiciado poderão requerer qualquer diligência, que será realizada, ou não, a juízo da autoridade”. 
Código Processo Penal. Tal norma também é reflexo do princípio da obrigatoriedade da ação penal antes analisado. ${ }^{136}$

O artigo 16 da Lei Adjetiva Penal proíbe o Ministério Público de requerer a devolução do inquérito à Autoridade Policial, exceto se faltarem diligências imprescindíveis ao oferecimento da denúncia. Raramente tal determinação é observada pelos membros do órgão ministerial, que, imotivadamente, costumam requerer o retorno dos autos ao Distrito Policial, mesmo após terem sido relatados, para a execução de medidas inócuas ou inoportunas ou, o que é pior, sem indicar a diligência a ser efetuada pela Autoridade Policial.

Os atos ultimados no inquérito policial devem assumir a forma escrita, segundo o artigo $9^{\circ}$ do Código de Processo Penal. Os autos acompanham a denúncia ou queixa quando servir para embasá-las (artigo 12 do Código de Processo Penal).

Normalmente, os atos investigatórios são públicos, por ser esta a regra vigente no ordenamento jurídico nacional para qualquer atividade realizada por órgão da Administração Pública. Contudo, o artigo 20 do Código de Processo Penal permite que a Autoridade Policial assegure no inquérito policial o sigilo necessário à elucidação do fato ou exigido pelo interesse da sociedade.

A limitação da publicidade, como visto, pode ser apenas para terceiros, alheios à persecução penal (sigilo externo), ou pode abranger também o imputado com relação a determinados atos (sigilo interno).

Oportuno notar que, a teor do disposto nos artigos 39, §5º e 40 do Código de Processo Penal, o inquérito policial não é essencial para a instauração da ação penal. No Brasil, adota-se o sistema facultativo de investigação criminal, ou seja, o Ministério Público ou o ofendido podem acusar, sem prévia investigação policial, caso tenham provas suficientes da materialidade e da autoria delitiva.

${ }^{136}$ MORAES, Bismael B., Direito e Polícia..., p. 287. 


\section{III.6. Os sujeitos envolvidos no inquérito policial}

\section{III.6.1. Polícia Judiciária}

A Autoridade Policial preside o inquérito policial e deve efetuar diversas atividades destinadas à elucidação do fato criminoso e de sua autoria. Como órgão encarregado da investigação preliminar, a Autoridade Policial desempenha duas funções principais: obtém os primeiros dados informativos e impede o perecimento dos elementos materiais relacionados à prática delituosa noticiada.

Os artigos $6^{\circ}$ e 13 do Código de Processo Penal fixam o rol de providências a cargo da Autoridade Policial, quais sejam:

o dirigir-se ao local do crime e providenciar para que não se alterem o estado e conservação das coisas, até a chegada dos peritos criminais;

o apreender os objetos pertinentes após liberação pelos peritos criminais;

o colher todas as provas necessárias ao esclarecimento do fato e suas circunstâncias;

o ouvir o ofendido e o indiciado;

o proceder a reconhecimento de pessoas e coisas e a acareações;

o determinar a realização de exames periciais;

o ordenar a identificação do indiciado pelo processo datiloscópico, se possível, e fazer juntar aos autos sua folha de antecedentes criminais;

o averiguar a vida pregressa do indiciado, sua condição econômica, sua atitude e estado de ânimo antes e depois do crime e durante ele, bem como quaisquer outros elementos que contribuírem para a apreciação do seu temperamento e caráter;

o fornecer às Autoridades Judiciárias as informações necessárias para a instrução e julgamento dos processos;

o realizar as diligências requisitadas pelo Juiz ou pelo Ministério Público;

o cumprir os mandados de prisão expedidos pelas Autoridades Judiciárias;

o representar acerca da prisão preventiva.

$\mathrm{O}$ artigo $7^{\mathrm{o}}$ do Código de Processo Penal faculta à Autoridade Policial providenciar a reprodução simulada dos fatos, desde que não contrarie a moralidade ou a ordem pública. A reconstituição do crime não pode ferir o direito do imputado a não se auto-incriminar, corolário da garantia constitucional da ampla defesa. Assim, o imputado não pode ser compelido a realizar tal diligência contra a sua vontade. 
O artigo 18 do Código de Processo Penal permite que a Autoridade Policial, após o arquivamento do inquérito, prossiga na apuração dos fatos se tiver notícia de novas provas. Já o artigo 22 do referido diploma legal, com a clara intenção de agilizar as investigações, atribui à Autoridade Policial o poder de determinar diligências em circunscrição de outra, independentemente de precatórias ou requisições.

A Autoridade Policial não pode decretar, por conta própria, medidas restritivas de direitos fundamentais, tais como busca e apreensão domiciliar, interceptação telefônica, quebra de sigilo de dados e medidas cautelares pessoais ou reais. Nesses casos, deve haver prévia autorização judicial, sob pena de nulidade absoluta da prova.

\section{III.6.2. Ministério Público}

O Ministério Público, por força do disposto no artigo 5º II, do Código de Processo Penal, deve requisitar a instauração de inquérito policial ao tomar conhecimento de possível infração penal.

Cabe, ainda, ao Ministério Público requisitar diligências à Autoridade Policial, que estará obrigada a realizá-las em virtude do disposto no artigo 13, II, do Código de Processo Penal.

Além disso, exerce o controle externo da atividade policial, conforme prescreve o artigo 129, VII, da Constituição da República. No intuito de regulamentar essa função fiscalizatória, foi promulgada a Lei Complementar n. ${ }^{\circ}$ 75/93 (Estatuto do Ministério Público da União), que tratou do tema em seus artigos $3^{\circ}, 9^{\circ}$ e 10 . O primeiro colocou os preceitos que pautam a atuação do Ministério Público no exercício do controle externo da atividade policial. ${ }^{137} \mathrm{O}$ segundo, por sua vez, enumerou os poderes conferidos ao órgão ministerial, a saber:

\footnotetext{
137 “Art. 3․ O Ministério Público da União exercerá o controle externo da atividade policial tendo em vista: a) o respeito aos fundamentos do Estado Democrático de Direito, aos objetivos fundamentais da República Federativa do Brasil, aos princípios informadores das relações internacionais, bem como aos direitos assegurados na Constituição Federal e na lei;

b) a preservação da ordem pública, da incolumidade das pessoas e do patrimônio público;

c) a prevenção e a correção de ilegalidade ou de abuso de poder;

d) a indisponibilidade da persecução penal;

e) a competência dos órgãos incumbidos da segurança pública”.
} 
o ter livre ingresso em estabelecimentos policiais ou prisionais;

o ter acesso a quaisquer documentos relativos à atividade-fim policial;

o representar à autoridade competente pela adoção de providências para sanar a omissão indevida, ou para prevenir ou corrigir ilegalidade ou abuso de poder;

o requisitar a instauração de inquérito policial para apurar a omissão ou fato ilícito ocorrido no exercício da atividade policial;

o promover a ação penal por abuso de poder.

No Estado de São Paulo, o Ministério Público editou o Ato n. ${ }^{\circ}$ 98, de 30 de setembro de 1996, e o Ato n. ${ }^{\circ}$ 119, de 13 de maio de 1997, com normas específicas sobre a fiscalização da atividade da Polícia Judiciária e da Polícia Militar, respectivamente.

Para Aury Lopes Jr., o legislador foi tímido ao regular o controle externo da atividade policial pelo Parquet, pois não criou mecanismos que lhe permitissem interferir no seu exercício, mas tão-somente controlar a sua legalidade. Segundo o autor, “o mais importante - a chamada dependência funcional - não foi regulado e o Ministério Público continua sem poder, efetivamente, controlar a atividade policial no curso do inquérito policial". 138

Todavia, esta dependência funcional acabaria por ferir a indispensável autonomia da Polícia Judiciária no tocante à apuração de infrações penais, transformando o inquérito policial em verdadeira investigação ministerial, com o Ministério Público guiando os rumos da persecução prévia. Seria um meio, portanto, de burlar o texto constitucional (artigo 144, §4º da Constituição da República), o qual, conforme ressaltado anteriormente, veda a condução da investigação preliminar pelo Parquet.

\footnotetext{
“Art. $9^{\circ}$ O Ministério Público da União exercerá o controle externo da atividade policial por meio de medidas judiciais e extrajudiciais podendo:

I - ter livre ingresso em estabelecimentos policiais ou prisionais;

II - ter acesso a quaisquer documentos relativos à atividade-fim policial;

III - representar à autoridade competente pela adoção de providências para sanar a omissão indevida, ou para prevenir ou corrigir ilegalidade ou abuso de poder;

IV - requisitar à autoridade competente para instauração de inquérito policial sobre a omissão ou fato ilícito ocorrido no exercício da atividade policial;

V - promover a ação penal por abuso de poder".

"Art. 10. A prisão de qualquer pessoa, por parte de autoridade federal ou do Distrito Federal e Territórios, deverá ser comunicada imediatamente ao Ministério Público competente, com indicação do lugar onde se encontra o preso e cópia dos documentos comprobatórios da legalidade da prisão”.

${ }^{138}$ Sistemas..., p. 151.
} 
A legislação pátria já permite ao Ministério Público intervir no inquérito policial, por meio da requisição de diligências necessárias à formação da sua opinio delicti e da fiscalização de eventuais abusos cometidos pela Autoridade Policial no desempenho de suas funções.

Logo, não seria razoável criar uma subordinação funcional da Polícia Judiciária ao Ministério Público, pois aquele órgão, como o próprio nome diz, tem função judiciária e não acusatória. Por isso, deve atuar de maneira isenta, recolhendo todos os dados que interessem à elucidação dos fatos investigados.

\section{- O Ministério Público como parte na persecução penal}

Existe acirrado debate a respeito da concepção do Ministério Público como parte na persecução penal e sobre a sua pretensa imparcialidade no exercício de suas funções. ${ }^{139}$

Há quem defenda a qualificação do Ministério Público como "parte imparcial”. ${ }^{140}$ Para tanto, aduz-se que o Parquet não teria interesse jurídico oposto ao do imputado, mas se pautaria pelo interesse público de busca da verdade para correta aplicação da lei.

Outrossim, sustenta-se a imparcialidade do Ministério Público, com base no artigo 127, caput, da Constituição da República, que lhe outorga a defesa da ordem jurídica, do regime democrático e dos interesses sociais e individuais indisponíveis. Assim, o Ministério Público teria o dever de agir, imparcialmente, na procura de provas da materialidade e autoria delitiva, sejam favoráveis, ou não, ao imputado.

De outro lado, existem aqueles que vêem o Ministério Público como órgão estatal cuja função primordial é exercer em Juízo a pretensão punitiva. Como tal, seria

\footnotetext{
${ }^{139}$ Os principais argumentos desta discussão foram sintetizados por Gustavo Henrique Righi Ivahy Badaró: Ônus da prova..., pp. 207/25.

${ }^{140}$ NORONHA, Edgard Magalhães. Curso de Direito Processual Penal. 28a ed.. São Paulo: Saraiva, 1998, p. 179; PEDROSO, Fernando de Almeida. Processo Penal. O direito de defesa: repercussão, amplitude e limites. $3^{\mathrm{a}}$ ed.. São Paulo: Revista dos Tribunais, 2001, p. 39; MIRABETE, Julio Fabbrini. Processo Penal. ${ }^{\mathrm{a}}$ ed.. São Paulo: Atlas, 1996, p. 329; JARDIM, Afrânio Silva. Direito Processual Penal. 11 ${ }^{\mathrm{a}}$ ed. Rio de Janeiro: Forense, 2002, p. 219.
} 
parte na persecução penal, ou seja, titular de posições jurídicas ativas e passivas na relação jurídica processual. ${ }^{141}$

Em sentido material, partes são os sujeitos que compõem a relação jurídica material: de um lado, o titular do direito subjetivo (interesse protegido); de outro, o titular da obrigação ou do dever (interesse subordinado). Em sentido processual, partes são autor e réu, isto é, aquele que deduz pretensão em juízo e aquele em face de quem se deduz tal pretensão. $^{142}$

No âmbito penal, existem dois interesses jurídicos em jogo: o ius libertatis e o ius puniendi. Os titulares desses interesses, respectivamente o acusado e o Estado, constituem, portanto, as partes da relação jurídica material que fundamenta o processo criminal.

O ius puniendi do Estado é efetivado, processualmente, por intermédio do Ministério Público, titular da ação penal - com exceção dos casos em que a legitimação é do particular ofendido -, a partir do momento em que existir prova suficiente da materialidade e autoria delitiva. Desse modo, na esfera penal, o Ministério Público é parte em sentido processual, em contraponto ao acusado. ${ }^{143}$

Dentro de um processo penal de contornos nitidamente acusatórios, como é atualmente o brasileiro, o órgão ministerial deve necessariamente assumir a posição de parte acusadora, legitimada a levar em Juízo a pretensão punitiva estatal. Desse modo, a atuação parcial do Parquet, suscitando os elementos pertinentes à tese acusatória, é essencial para a formação da dialética processual que abalizará a opinião do Juiz. ${ }^{144}$

\footnotetext{
141 “O Ministério Público é parte como órgão (e não representante) do Estado. O aspecto ritual do processo a tanto leva, porque, além de o Ministério Público ser fiscal da aplicação da lei, ele exerce a função de acusar. Essa última é sua atribuição precípua, uma vez que o processo está organizado em forma contraditória. Pode acontecer que durante o processo o Ministério Público se convença da inocência do acusado e peça para ele a absolvição. Mas o contraste inicial, nascido com a denúncia, permanece, uma vez que a lei não dispensa o juiz de apurar a verdade acerca da acusação e de condenar, se entender que o réu é culpado" (TORNAGHI, Hélio. Curso de Processo Penal. $9^{a}$ ed. São Paulo: Saraiva, 1995, vol. 1, pp. 485/86). Ver, também, TUCCI, Rogério Lauria, Direitos e garantias..., pp. 176/77; BADARÓ, Gustavo Henrique Righi Ivahy, Ônus da prova..., pp. 209/10; e CALABRICH, Bruno, Investigação..., pp. 126/27.

${ }^{142}$ ARAÚJO CINTRA, Antonio Carlos; GRINOVER, Ada Pellegrini e DINAMARCO, Cândido Rangel. Teoria Geral do Processo. 14ª ed.. São Paulo: Malheiros, 1998, pp. 293/94; e TUCCI, Rogério Lauria. Teoria do direito processual penal: jurisdição, ação e processo penal (estudo sistemático). São Paulo: Revista dos Tribunais, 2002, pp. 182/89.

${ }^{143}$ TUCCI, Rogério Lauria, Teoria do direito processual penal..., p. 186.

144 "O modelo acusatório exige um processo no qual haja uma dualidade de partes, em igualdade de condições, mas com interesses distintos. Definido o sistema, os sujeitos que neles atuam devem ter a sua
} 
A atuação parcial do Ministério Público, direcionada a comprovar a prática da infração penal, é constatada empiricamente. É quase impossível vislumbrar o órgão ministerial agindo em prol do imputado - e nem seria natural que isso ocorresse -, pois, enquanto parte, o Ministério Público procura comprovar a existência dos elementos objetivos e subjetivos do crime.

Em recente decisão, o pleno do Supremo Tribunal Federal examinou tal questão e concluiu que o Ministério Público possui a qualidade de parte ao longo de toda a relação jurídica processual penal. Mesmo em grau recursal, não pode ser visto como mero custos legis. Com base nisso, a Corte Suprema concedeu, por unanimidade, ordem de habeas corpus para o fim de anular julgamento de recurso em sentido estrito, no qual a defesa foi obrigada a realizar sustentação oral antes do representante do Parquet. ${ }^{145}$

O fato de o Ministério Público ser parte não colide com a necessária isenção que este órgão deve ter como fiscal da aplicação da lei. Afinal, enquanto órgão do Estado, “deve respeitar os imperativos legais e morais que governam a atuação estatal. É ilegal e imoral a condenação de uma pessoa inocente e o Estado, seja por meio do Ministério

função determinada coerentemente com os ditames do modelo processual escolhido. Num processo penal verdadeiramente acusatório, é necessário rever a posição do Ministério Público como parte imparcial.

(...)

Contudo, para que o processo acusatório ou processo de partes se desenvolva em toda a sua potencialidade, com a dialética processual permitindo uma correta reconstrução dos fatos, é necessário que no processo atuem partes com interesse antagônicos ou contrapostos” (BADARÓ, Gustavo Henrique Righi Ivahy, Ônus da prova..., pp. 215/217).

${ }^{145}$ STF, HC n. ${ }^{\circ} 87.926 /$ SP, Rel. Min. Cezar Peluso, j. 20.02.2008. Confira-se trecho do voto do Min. Relator, verbis: "Estou em que fere, igualmente, as garantias da defesa todo o expediente que impeça o acusado de, por meio do defensor, usar da palavra por último, em sustentação oral, sobretudo nos casos de julgamento de recurso exclusivo da acusação. Invocar, para negá-lo, a qualidade de custos legis do Ministério Público perante os tribunais, em sede recursal, parece-me caracterizar um desses artifícios lingüísticos que tendem a fraudar as garantias essenciais a sistema penal verdadeiramente acusatório ou de partes.

(...)

De fato, na ação penal de iniciativa pública, condicionada ou não, o Ministério Público é parte, se não em sentido material - porque o poder-dever de acusar e punir não é dele, mas do Estado -, é-o, ao menos formalmente, parte acusadora.

(...)

Desse modo, entendo difícil, senão ilógico, cindir a atuação do Ministério Público no campo recursal, em processo-crime: não há excogitar que, em primeira instância, seu representante atue apenas como parte formal e, em grau de recurso - que, frise-se, constitui mera fase do mesmo processo -, se dispa dessa função para entrar a agir como simples fiscal da lei.

Órgão uno e indivisível, na dicção do art. 127, $§ 1^{\circ}$, da Constituição da República, não há como admitir que o Ministério Público opere tão-só como custos legis no curso de processo onde, em fase diversa, já tenha funcionado, mediante outro órgão, como encarregado da acusação, sob pena de se violentar a própria sintaxe acusatória do processo penal. O conteúdo da opinião legal, de fundo, exposto no parecer ou na sustentação oral, é de pouco relevo neste tema. Ou seja, ainda que, no mérito, o Ministério Público postule a absolvição do acusado, continua sempre órgão incumbido da acusação e não deixa de agir ou de poder agir como parte 
Público, seja pelo Poder Judiciário, não pode admitir tal situação nem concorrer para ela". 146

Como salientado por Hélio Tornaghi, "não há, pois, conflito entre a imparcialidade que o Ministério Público deve observar como custodio da lei e o seu caráter de parte. Imparcial ele deve ser apenas na fiscalização, na vigilância, no zelo da lei. Deve fazê-la cumprir no tempo, na forma, no lugar por ela própria determinados. Mas essa é apenas uma de suas funções e não é a que ele tem como parte. Como tal, cabe-lhe promover a aplicação da lei penal ao acusado, persegui-lo (no sentido técnico, é claro), carrear para o processo todas as provas de sua responsabilidade, chamar a atenção dos julgadores para as circunstâncias (lato sensu) que possam onerá-lo, agravando a pena ou qualificando o crime”. 147

Contudo, a atuação proba e legal que o Ministério Público deve ter, enquanto órgão estatal, não implica sua imparcialidade processual. Tal atributo é exclusivo do Magistrado, sendo garantido justamente pela atuação parcial dos contendores. O fato de o Ministério Público ter o dever de zelar pela correta aplicação da lei e pela observância dos direitos e garantias fundamentais, ${ }^{148}$ não lhe retira, de forma alguma, o caráter de parte. ${ }^{149}$

Em realidade, o discurso em favor da imparcialidade do Ministério Público serve tão-somente para conferir maior credibilidade à tese acusatória, supostamente neutra e justa, em detrimento da argumentação defensiva. ${ }^{150}$

que é. Conclusão diversa levaria à concepção de processo de parte única, o acusado, o que parece absurdo diante de um sistema garantista, acusatório, antagônico, marcado pela garantia de contraditoriedade”.

146 BADARÓ, Gustavo Henrique Righi Ivahy, Ônus da prova..., pp. 221. Aduz Bruno Calabrich que “a imparcialidade do Ministério Público, nesses termos, associa-se à idéia de: (a) impessoalidade; e (b) desvinculação apriorística de pretensões acusatórias ou absolutórias. A despeito de ser parte, sua função precípua é a defesa da lei e da Constituição, podendo e devendo, por este mesmo fundamento, por exemplo, promover o arquivamento de um inquérito policial (ou dos autos de quaisquer outros instrumentos de investigação), quando ausente a justa causa para a denúncia (arts. 28, 43 e 648, I, do CPP), ou pedir a absolvição de um acusado que verifique ser inocente, tomando todas as medidas cabíveis em sua defesa, se for o caso" (Investigação..., pp. 126/27).

${ }^{147}$ Curso de Processo Penal..., p. 486. Também TUCCI, Rogério Lauria, Direitos e garantias..., pp. 188/90.

148 De acordo com o artigo 129, II, da Constituição da República, são funções institucionais do Ministério Público: “zelar pelo efetivo respeito dos Poderes Públicos e dos serviços de relevância pública aos direitos assegurados nesta Constituição, promovendo as medidas necessárias a sua garantia”.

149 ABADE, Denise Neves. Garantias do Processo Penal acusatório - o novo papel do Ministério Público no Processo Penal de partes. São Paulo: Renovar, 2005, p. 54.

${ }^{150}$ BADARÓ, Gustavo Henrique Righi Ivahy, Ônus da prova..., p. 221. 
III.6.3. Juiz

A Autoridade Judiciária tem o dever de requisitar a instauração de inquérito policial, após tomar conhecimento de possível conduta criminosa, nos termos do artigo $5^{\circ}$, II, do Código de Processo Penal. Além disso, segundo o artigo 10, §3º da Lei Adjetiva Penal, cabe ao Juiz apreciar o pedido de dilação do prazo das investigações, quando o fato for de difícil elucidação e o imputado estiver solto.

A principal função do Juiz, no curso do inquérito policial, é verificar a legalidade das diligências praticadas pela Autoridade Policial, legitimando esses atos, e tutelar os direitos fundamentais do imputado.

Essa atuação judicial pode ser a posteriori, ou seja, após a realização da atividade policial. Nesse caso, o Juiz analisa a observância aos ditames constitucionais e legais, sob pena de reconhecer a invalidade do ato, como, por exemplo, o relaxamento da prisão em flagrante ilegal.

Compete, ainda, ao Magistrado decidir sobre a concessão de liberdade provisória e o arbitramento de fiança, nos termos dos artigos 321 e seguintes do Código de Processo Penal.

O Juiz também examina o pedido de dilação das investigações, previsto no artigo 16 do Código de Processo Penal, deferindo ou não tal solicitação. Ademais, pode declinar da competência para apreciação do caso, se houver motivos para tanto, observado o disposto nos artigos 69 e seguintes do Código de Processo Penal.

Por outro lado, se a atividade investigatória implicar restrição a direitos fundamentais, o controle judicial será prévio, isto é, a Autoridade Judiciária deve autorizar a realização do ato, uma vez atendidos os pressupostos legais e o princípio da proporcionalidade.

De acordo com este postulado, o Magistrado deve sopesar os valores em confronto e constatar se, no caso concreto, cabe limitação de direito individual para a produção de prova criminal. 
A doutrina aponta pressupostos e requisitos balizadores da aplicação desse princípio. Dentre os pressupostos, identificam-se o da legalidade e o da justificação teleológica. O primeiro diz respeito à previsão legal da medida restritiva de direito individual. De acordo com o segundo, a limitação do direito individual deve visar à concretização de valores relevantes do sistema constitucional. ${ }^{151}$

Por sua vez, constituem requisitos ou subprincípios da proporcionalidade: (i) adequação ou idoneidade, isto é, a medida restritiva deve ser apta a alcançar o fim pretendido, ter duração razoável e condizente com a sua finalidade e recair sobre indivíduo que reúna as circunstâncias exigíveis para a sua atuação; (ii) necessidade, isto é, a medida restritiva deve ser a que atinge o fim almejado com a menor limitação possível ao direito individual, inexistindo medidas alternativas menos gravosas e (iii) proporcionalidade em sentido estrito, isto é, a ponderação em cada caso dos valores conflitantes (o que respalda a medida restritiva e o que tutela o direito individual a ser violado), devendo prevalecer o de maior relevância. ${ }^{152}$

Esclarece Mariângela Gama de Magalhães Gomes que “o princípio da proporcionalidade tem o seu principal campo de atuação no âmbito dos direitos fundamentais, enquanto critério valorativo constitucional determinante das máximas restrições que podem ser impostas na esfera individual dos cidadãos pelo Estado, e para a consecução de seus fins. Assim, integra uma exigência ínsita no Estado de Direito enquanto tal, que impõe a proteção do indivíduo contra intervenções estatais desnecessárias ou excessivas que gravem o cidadão mais do que o indispensável para a proteção dos interesses públicos”. 153

\footnotetext{
${ }^{151}$ SCARANCE FERNANDES, Antonio, Processo..., p. 53.

152 Ibid., pp. 53/55.

${ }^{153}$ O princípio da proporcionalidade no direito penal. São Paulo: Revista dos Tribunais, 2003, p. 35. Em sua obra, na qual analisa o princípio da proporcionalidade à luz do Direito Penal, a autora explicita as regras constitucionais das quais se pode inferir a proporcionalidade, a saber: (i) Estado Democrático de Direito (artigo $1^{\circ}$, caput, da Constituição da República); (ii) Justiça (preâmbulo e artigo $3^{\circ}$, I, da Constituição da República); (iii) liberdade e igualdade (artigo $5^{\circ}$, caput, da Constituição da República; (iv) dignidade da pessoa humana (artigo $1^{\circ}$, III, da Constituição da República); proibição de penas cruéis e desumanas (artigo $5^{\circ}$, III, da Constituição da República); (v) proporcionalidade do direito de resposta (artigo 5º V, da Constituição da República); (vi) devido processo legal (artigo 5º, LIV, da Constituição da República) (GOMES, Mariângela Gama de Magalhães, O princípio..., pp. 63/72). Por outro lado, Maria Cecília Pontes Carnaúba entende que o princípio da proporcionalidade está positivado no artigo $5^{\circ}$, §2º da Constituição da República. In verbis: “O dispositivo em análise consagra expressamente a aplicação do princípio da proporcionalidade, uma vez que hierarquiza os valores tutelados pela Constituição, impedindo que os direitos e garantias individuais sobreponham-se a interesses tão valiosos quanto eles" (Prova Ilícita. São Paulo: Saraiva, 2000, p. 100).
} 
Importante ressalvar que o princípio da proporcionalidade deve ser utilizado de forma criteriosa pelo Magistrado, que não pode se imiscuir em questões políticas próprias do legislador. ${ }^{154}$ Para tanto, a Autoridade Judiciária deve motivar adequadamente as decisões concernentes à restrição de direitos fundamentais, pautando-se pelos critérios acima mencionados, aptos a aferir a proporcionalidade da medida.

Dentre as principais medidas ultimadas no inquérito policial que dependem de autorização judicial, vale citar a decretação de prisão temporária ou preventiva; ${ }^{155}$ a busca e apreensão domiciliar; ${ }^{156}$ o seqüestro e arresto de bens ${ }^{157}$ e a quebra do sigilo das comunicações e de dados. ${ }^{158}$

De acordo com o artigo 18 do Código de Processo Penal, o Juiz deve ordenar o arquivamento do inquérito policial, se, ao cabo das investigações, o Ministério Público manifestar-se nesse sentido. Caso discorde da opinião do órgão ministerial, o Magistrado pode determinar a remessa dos autos ao Procurador-Geral, nos termos do artigo 28 do Código de Processo Penal. Tal norma fere a imparcialidade do Juiz, que, para decidir sobre o envio dos autos ao Procurador-Geral, efetua indevidamente juízo acusatório. Tanto que o

\footnotetext{
154 Salienta Mariângela Gama de Magalhães Gomes que “o problema mais grave que surge no juízo de proporcionalidade é o consistente em evitar que o órgão jurisdicional, de juiz da legitimidade da lei, transforme-se em juiz da oportunidade da escolha legislativa, tomando o lugar do legislador na avaliação das razões políticas que determinaram a adoção de certa disciplina legislativa - embora seja verdade que em muitos casos a linha limítrofe entre legitimidade e mérito apresente-se demasiadamente estreita, ou quase imperceptível -, com o conseqüente risco de que o juízo de constitucionalidade possa invadir escolhas que são reservadas ao legislador" (O princípio..., pp. 213/14).

${ }^{155}$ A prisão temporária está regulada na Lei n. ${ }^{\circ}$ 7.960, de 21 de dezembro de 1989, enquanto a prisão preventiva nos artigos 311 e seguintes do Código de Processo Penal. Segundo o artigo $2^{\circ}$ da Lei n. ${ }^{\circ} 7.960 / 89$, "a prisão temporária será decretada pelo Juiz, em face da representação da autoridade policial ou de requerimento do Ministério Público, e terá o prazo de 5 (cinco) dias, prorrogável por igual período em caso de extrema e comprovada necessidade”. Por sua vez, o artigo 311 do Código de Processo Penal dispõe que "em qualquer fase do inquérito policial ou da instrução criminal, caberá a prisão preventiva decretada pelo juiz, de ofício, a requerimento do Ministério Público, ou do querelante, ou mediante representação da autoridade policial”.

${ }^{156}$ As diligências de busca e apreensão constam dos artigos 240 e seguintes do Código de Processo Penal. A interpretação desses dispositivos conjugada com o artigo $5^{\circ}$, XI, da Constituição da República, que prevê a inviolabilidade de domicílio, revela a necessidade de prévio mandado judicial para a realização dessas medidas.

${ }^{157}$ Tais medidas cautelares patrimoniais estão previstas nos artigos 125 e seguintes do Código de Processo Penal. Por implicarem restrição ao patrimônio do imputado, também pressupõem autorização judicial, como se vê dos artigos 127, 132, 133 e 137, todos do Código de Processo Penal. Também o artigo $4^{\circ}$, caput, da Lei n. ${ }^{\circ}$ 9.613/98, prevê a possibilidade de o Juiz decretar o seqüestro de bens, direitos ou valores do acusado, que constituam objeto de crimes de lavagem de dinheiro.

${ }^{158} \mathrm{O}$ sigilo das comunicações e de dados integra o direito fundamental à intimidade e apenas pode ser violado mediante autorização judicial, por força do disposto no artigo 5․ XII, da Constituição da República. Com o objetivo de regulamentar a quebra desse sigilo, foram editadas a Lei n. ${ }^{\circ}$ 9.296, de 24 de julho de 1996, relativa à interceptação de comunicações telefônicas, e a Lei Complementar n. $^{\circ} 105$, de 10 de janeiro de 2001, referente ao sigilo das operações de instituições financeiras.
} 
Projeto de Lei n. ${ }^{\circ}$ 4.209/01, atinente à investigação criminal, altera o artigo 28 do Código de Processo Penal, excluindo a possibilidade de o Juiz remeter os autos à Procuradoria. ${ }^{159}$

Por fim, se houver acusação formal, a Autoridade Judiciária deve analisar a sua viabilidade conforme o novo rito procedimental trazido pela Lei n. ${ }^{\circ} 11.719$, de 20 de junho 2008. De acordo com esse estatuto, o Juiz rejeitará liminarmente a inicial acusatória em três circunstâncias: (i) se for manifestamente inepta; (ii) faltar pressuposto processual ou condição para o exercício da ação penal; ou (iii) faltar justa causa para o exercício da ação penal (artigo 395 do Código de Processo Penal).

Se não for hipótese de rejeição liminar, o Juiz deve receber a denúncia ou queixa e determinar a citação do acusado para apresentar resposta à acusação, por escrito, no prazo de 10 (dez) dias (artigo 396 do Código de Processo Penal). ${ }^{160}$

Após a apresentação desta resposta, o Magistrado deve examinar novamente o suporte formal e material da peça vestibular - cotejando-a com os argumentos trazidos pela defesa - e proferir decisão de recebimento ou de rejeição da exordial, ou de absolvição sumária do acusado (artigos 396, 397 e 399 do Código de Processo Penal).

\section{- A questão do Juiz investigador}

\footnotetext{
159 Consoante o Projeto de Lei, em caso de promoção de arquivamento, os autos da investigação devem ser automaticamente encaminhados ao órgão superior do Ministério Público, que pode ratificar a promoção ou, em caso de discordância, designar outro representante do Ministério Público para oferecer a denúncia.

${ }^{160}$ Esclareça-se que o recebimento da exordial acusatória, mencionado no artigo 396 do Código de Processo Penal, deve ser interpretado como mero despacho de processamento, uma vez presentes os requisitos legais mínimos. O recebimento formal da acusação, com seus conseqüentes efeitos jurídicos, ocorre somente após o oferecimento da resposta pelo imputado, na forma prevista no artigo 399 do Código de Processo Penal. Nesse passo, leciona Marcos Alexandre Coelho Zilli, verbis: “E foi essa mesma preocupação com acusações desprovidas de requisitos mínimos que levaram à previsão de uma filtragem liminar a ser realizada pelo juiz. Assim, se desde logo constatada a inépcia, a ausência de pressuposto processual, a ausência de condição da ação ou a ausência de justa causa, a denúncia ou queixa será rejeitada liminarmente. Obviamente, nova peça poderá ser apresentada, desde que corrigidos aqueles vícios. O que se pretende, reitere-se, é evitar a desnecessária movimentação da máquina judiciária. Por outro lado, caso o juiz repute presentes aqueles requisitos mínimos, determinará o processamento sem que tal ato implique recebimento formal da acusação com todos os efeitos jurídicos que lhe são próprios. É, note-se, a melhor leitura a ser dada à expressão 'receber' inserida de última hora no artigo 396. Cuida-se, portanto, de uma aceitação liminar e que leva, tão somente, ao chamamento daquele que foi indicado como o responsável pelo fato imputado" ("Hamlet entre nós” in Boletim do Instituto Brasileiro de Ciências Criminais, n.o 192, novembro/2008, p. 06). Vide, também, TOURINHO FILHO, Fernando da Costa. Manual de Processo Penal. 11 a ed.. São Paulo: Saraiva, 2009, pp. 202/03. Em sentido contrário, parte da doutrina defende que o recebimento da exordial acusatória ocorreria após a sua primeira análise pelo Magistrado, nos termos do artigo 396 do Código de Processo Penal (NUCCI, Guilherme de Souza. Código de Processo Penal..., pp. 715 e 719/20 e SANTOS, Leandro Galluzzi dos. "Procedimentos - Lei 11.719, de 20.06.2008” in As reformas no Processo Penal: as novas Leis de 2008 e os projetos de reforma. MOURA, Maria Thereza Rocha de Assis (org.). São Paulo: Revista dos Tribunais, 2008, p. 328).
} 
Tendo em vista as atividades desenvolvidas pelo Juiz no inquérito policial, constata-se que atua, em regra, como garante e não como investigador, zelando pela efetiva aplicação dos direitos e garantias fundamentais. Nem poderia ser diferente, uma vez que a atividade investigatória do Juiz aniquilaria a sua imparcialidade, um dos pilares fundamentais do sistema acusatório. ${ }^{161}$

Todavia, o artigo 13, II, do Código de Processo Penal, atribuiu poderes investigatórios ao Juiz, pois lhe outorgou a faculdade de requisitar diligências à Autoridade Policial, que estará adstrita a cumpri-las. ${ }^{162}$

Nos últimos anos, foram promulgadas leis que incrementaram os poderes tipicamente investigatórios da Autoridade Judiciária, quais sejam: (i) o artigo 3º caput, da Lei n. ${ }^{\circ}$ 9.034/95 (Lei do Crime Organizado), permite ao Juiz realizar, pessoalmente, diligências de acesso a dados, documentos e informações bancárias e financeiras; ${ }^{163}$ (ii) o

161 Assinala Antonio Magalhães Gomes Filho que a primeira e mais essencial garantia do processo é a existência do juiz independente e imparcial. A independência refere-se à autonomia do Juiz face a determinações de outros órgãos, integrantes ou não do Poder Judiciário. A imparcialidade “constitui um valor que se manifesta sobretudo no âmbito interno do processo, traduzindo a exigência de que na direção de toda a atividade processual - e especialmente nos momentos de decisão - o juiz se coloque sempre super partes, conduzindo-se como um terceiro desinteressado, acima portanto dos interesses em conflito" (GOMES FILHO, Antonio Magalhães. A motivação das decisões penais. São Paulo: Revista dos Tribunais, 2001, p. 37).

${ }^{162}$ Denise Neves Abade lembra que até mesmo o artigo 5º II, do Código de Processo Penal, que confere à Autoridade Judiciária o poder de requisitar a instauração de inquérito policial, fere o princípio da imparcialidade do Juízo e, portanto, deve ser considerado inconstitucional (Garantias..., p. 175).

163 Dispõe o artigo $3^{\circ}$, caput, da Lei n. ${ }^{\circ}$ 9.034/95, que "nas hipóteses do inciso III do art. $2^{\circ}$ desta lei, ocorrendo possibilidade de violação de sigilo preservado pela Constituição ou por lei, a diligência será realizada pessoalmente pelo juiz, adotado o mais rigoroso segredo de justiça”. O referido inciso III do artigo $2^{\circ}$ da Lei n. ${ }^{\circ}$ 9.034/95 prevê como procedimento de investigação e formação de prova "o acesso a dados, documentos e informações fiscais, bancárias, financeiras e eleitorais”. No entanto, o Supremo Tribunal Federal, por meio da ADIN n. ${ }^{\circ}$ 1.570-2, julgada em 12 de fevereiro de 2004, declarou inconstitucional a referida norma no que se refere ao acesso a dados “fiscais” e "eleitorais”. Com relação às informações bancárias e financeiras, aduziu que tal matéria passou a ser regulamentada pelo artigo $1^{\circ}, \S 4^{\circ}$, IX, da Lei Complementar n. ${ }^{\circ}$ 105/01. Vale conferir trecho da decisão proferida pelo Min. Relator Dr. Maurício Corrêa, verbis: "Quanto à alegação de que teria sido violado o princípio do devido processo legal (CF, artigo 5, LIV), observa-se que o artigo $3^{\circ}$ da Lei 9034/95 efetivamente cria procedimento excepcional, não contemplado na sistemática processual penal contemporânea, dado que permite ao juiz colher pessoalmente as provas que poderão servir, mais tarde, como fundamento fático-jurídico de sua própria decisão. Indaga-se, por isso mesmo, se o magistrado está imune de influências psicológicas, de tal sorte que o dinamismo de seu raciocínio lógico-jurídico fique comprometido por idéias preconcebidas, pondo em risco a imparcialidade de sua decisão?!

Penso que não. Evidente que não há como evitar a relação de causa e efeito entre as provas coligidas contra o suposto autor do crime e a decisão a ser proferida pelo juiz. Ninguém pode negar que o magistrado, pelo simples fato de ser humano, após realizar pessoalmente as diligências, fique envolvido psicologicamente com a causa, contaminando sua imparcialidade.

(...)

Em verdade, a legislação atribuiu ao juiz as funções de investigador e inquisidor, atribuições essas conferidas

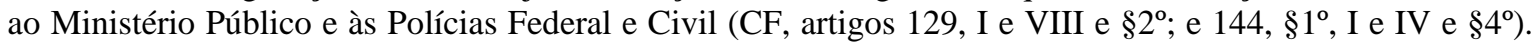


artigo $3^{\circ}$, caput, da Lei n. ${ }^{\circ}$ 9.296/96, autoriza o Juiz a requisitar, de ofício, a interceptação das comunicações telefônicas; ${ }^{164}$ e (iii) o artigo $4^{\text {o }}$, caput, da Lei n. ${ }^{\circ}$ 9.613/98, prevê a possibilidade de o Juiz decretar, de ofício, a apreensão e seqüestro de bens objeto de crime de lavagem de dinheiro. ${ }^{165}$

Na mesma trilha, a recente Lei n. ${ }^{\circ}$ 11.690/08, responsável por diversas alterações ao Código de Processo Penal, conferiu ao Juiz o poder de determinar, na fase de persecução prévia, a produção antecipada de provas consideradas urgentes e relevantes. De acordo com a nova redação do artigo 156 do Código de Processo Penal, a prova da alegação é ônus de quem a fizer, podendo o Juiz de ofício: “ordenar, mesmo antes de iniciada a ação penal, a produção antecipada de provas consideradas urgentes e relevantes, observando a necessidade, adequação e proporcionalidade da medida”.

A possibilidade de o Juiz efetuar atos investigatórios vem sendo bastante questionada pela doutrina. É que, num verdadeiro sistema acusatório, o Magistrado funciona como órgão suprapartes, adstrito à função de julgar. A prática de atos investigatórios pelo Juiz representa forma de acusação em sentido amplo, pois pressupõe pré-julgamentos a respeito da imputação, refletindo em sua imparcialidade. ${ }^{166}$

Ada Pellegrini Grinover, em análise do artigo $3^{\circ}$, caput, da Lei n. ${ }^{\circ}$ 9.034/95, afirmou a inconstitucionalidade do referido dispositivo, que atribuiu funções investigatórias à Autoridade Judiciária, por violar a garantia fundamental da imparcialidade do Juiz e o modelo acusatório instituído pela Constituição da República. ${ }^{167}$

Na mesma linha, Rogério Schietti Machado Cruz, ao comentar o novo texto do

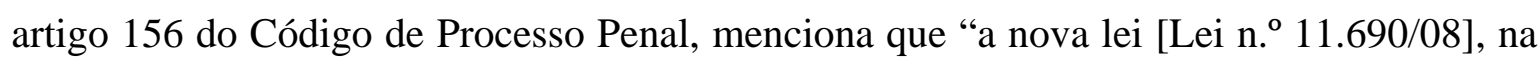

Tal figura revela-se incompatível com o sistema acusatório atualmente em vigor, que veda a atuação de ofício do órgão julgador” (STF, ADIN n. ${ }^{\circ}$ 1.570-2, Rel. Min. Maurício Corrêa, j. 12.02.2004).

164 “Art. $3^{\circ}$. A interceptação das comunicações telefônicas poderá ser determinada pelo juiz, de ofício ou a requerimento:

I - da autoridade policial, na investigação criminal;

II - do representante do Ministério Público, na investigação criminal e na instrução processual penal”.

165 “Art. $4^{\circ}$. O juiz, de ofício, a requerimento do Ministério Público, ou representação da autoridade policial, ouvido o Ministério Público em vinte e quatro horas, havendo indícios suficientes, poderá decretar, no curso de inquérito ou da ação penal, a apreensão ou o seqüestro de bens, direitos ou valores do acusado, ou existentes em seu nome, objeto dos crimes previstos nesta Lei, procedendo-se na forma dos arts. 125 a 144 do Decreto-Lei n. ${ }^{\circ}$ 3.689, de 3 de outubro de 1941 - Código de Processo Penal”.

${ }^{166}$ LOPES Jr., Aury, Sistemas..., pp. 169/70. Do mesmo autor, ver também Direito Processual Penal..., pp. $122 / 28$.

167 “Que juiz inquisidor é esse?” in Boletim do Instituto Brasileiro de Ciências Criminais, n. ${ }^{0}$ 30, junho/1995, p. 01. 
redação dada ao artigo 156, foi além do que deveria, ao permitir ao juiz ordenar, de ofício e 'mesmo antes de iniciada a ação penal', a produção antecipada de provas urgentes e relevantes, o que, como já dito, pode comprometer sua imparcialidade e desfigurar a estrutura acusatória do processo penal”. 168

Em sentido oposto, sustenta-se que a reforma legislativa não afetou o princípio da imparcialidade judicial, pois, mesmo no sistema acusatório, caberia ao Juiz certa iniciativa probatória, em atenção à busca da verdade material. ${ }^{169}$

Todavia, não se deve confundir a atividade investigatória do Juiz com a sua iniciativa instrutória no processo, isto é, a sua inquisitividade. Esta é plenamente admissível - e até mesmo desejável -, desde que exercida de forma subsidiária às partes e como instrumento para suprir as desigualdades naturais entre elas existentes. ${ }^{170}$

168 CRUZ, Rogério Schietti Machado. “Com a palavra, as partes” in Boletim do Instituto Brasileiro de Ciências Criminais, n. ${ }^{\circ}$ 188, julho/2008, p. 18. No mesmo sentido: "Indesejado, entretanto, é o poder inserto no inciso I do artigo 156, o qual permite a determinação, de ofício, mesmo antes de iniciada a ação penal, da produção de provas antecipadas. A previsão, se mal conduzida, pode levar o juiz ao perigoso terreno da atuação investigatória subvertendo-se, assim, o sentido de um processo penal de matriz acusatória” (ZILLI, Marcos, “O Pomar e as Pragas”..., p. 02). Conferir, também, COUTINHO, Jacinto Nelson de Miranda, “As reformas parciais do CPP e a gestão da prova: segue o princípio inquisitivo”..., pp. 12/13 e LOPES Jr., Aury, "Bom para quê(m)?..., p. 10.

169 “A atividade instrutória e a participação do juiz no processo vincula-se ao sistema processual adotado. Cada sistema processual define, ampliando ou restringindo, as funções do julgador, especificando-lhe atribuições e limitações. Outorgar ao juiz o poder de realizar provas, nos moldes da nova lei, não afronta o modelo processual adotado - inquisitório, na primeira fase e acusatório na segunda, ou, como preferem outros, integralmente acusatório - nem fere a indispensável imparcialidade do juiz.

A reconstrução do fato, na persecução penal, é obra de mão comum. Todos os sujeitos do processo acusador, acusado, vítima e julgador - devem atuar. Perquirir, investigar, buscar elementos de convicção não significa que o juiz substitui ou sobrepõe-se à defesa ou acusação. O juiz, por exemplo, ao determinar a produção de prova - testemunhal, pericial, documental ou qualquer outra -, não sabe e não tem como saber qual será o seu resultado e se será lastro para a absolvição ou condenação.

A atividade inquisitiva do juiz, na persecução penal, visando à formação de seu convencimento é supletiva e complementar à atividade das partes” (PITOMBO, Cleunice Valentim Bastos, "Considerações iniciais sobre a Lei 11.690/08”..., p. 20). Na mesma linha: SILVA, Ivan Luís Marques da. Reforma Processual Penal de 2008. São Paulo: Revista dos Tribunais, 2008, pp. 64/66; e NUCCI, Guilherme de Souza. Código de Processo Penal Comentado. $8^{a}$ ed.. São Paulo: Revista dos Tribunais, 2008, p. 346.

${ }^{170}$ GOMES FILHO, Antonio Magalhães, A motivação..., p. 42. Joaquim Canuto Mendes de Almeida salienta que o poder inquisitivo do Juiz não conflita com a contrariedade das partes, típica do processo penal acusatório, verbis: “A contrariedade das partes, na instrução definitiva, não é dispositiva, em face do poderdever inquisitivo do juiz da sentença condenatória ou absolutória. Uma vez que a este cabe certificar-se da verdade real, objetiva, exterior e anterior ao processo, a estrutura do contraditório processual penal submerge, por absorção, na atividade inquisitiva do magistrado, sem que, com isso, deixe de existir. E, assim, a contrariedade opera sem que, por existir, monopolize as iniciativas processuais; e não deixa de existir pelo fato de carecer de monopólio” (Princípios..., p. 190). 
A iniciativa instrutória do Juiz coaduna-se com uma visão publicista do processo, ${ }^{171}$ em que o Juiz deve desenvolver os esforços necessários para “apuração da verdade material ou atingível”. ${ }^{172}$ Como salientado por Marcos Alexandre Coelho Zilli, ${ }^{173}$ a iniciativa probatória das partes, típica de um processo penal acusatório, não suprime a atuação judicial, pois a marcha processual é feita de maneira cooperatória. ${ }^{174}$

Por outro lado, a Autoridade Judiciária não pode investigar, isto é, colher elementos informativos durante a persecução prévia, pois se tornaria verdadeiro inquisidor e deixaria de ser imparcial. ${ }^{175}$ A esse respeito, assinala Antonio Magalhães Gomes Filho que “é difícil imaginar que um juiz ativo na fase de investigação possa ser, ao mesmo tempo, um magistrado imparcial no momento da decisão, porque a tarefa de recolher elementos para a propositura da ação penal é, por natureza, parcial e, no nosso sistema, realizada unilateralmente pelos órgãos oficiais incumbidos da persecução”. ${ }^{176}$

Em outros termos, não cabe ao Juiz procurar fontes de prova, pois esta atividade é exclusiva das partes e pode afetar a sua imparcialidade. Contudo, se tomar conhecimento de alguma fonte, pode determinar a sua produção por algum meio de prova. $^{177}$

${ }^{171}$ Conforme Rogério Lauria Tucci, “a regra maior, a dita super-regra de Direito Processual Penal, é a correspondente ao caráter publicístico do respectivo processo. Com efeito, somente em âmbito penal, lato sensu considerado, todos os conflitos de interesses resultantes da prática de infração a norma material, sem exceção, são públicos” (Teoria do direito processual penal..., p. 226).

${ }^{172}$ Ibid., p. 177. A respeito da busca da verdade no processo penal, Marco Antonio de Barros destaca a impropriedade da distinção entre verdade material e formal. Reza o autor que "tais princípios perderam aquele encanto que seduziu intensamente a doutrina antiga, pois, seja no processo civil, seja no processo penal, interessa hoje pura e simplesmente descobrir a verdade, atributo de um juízo racional no qual firma-se a certeza do julgador. E a verdade possível de ser descoberta na ação penal é apenas e tão-somente a 'verdade processual'” (BARROS, Marco Antonio de. A busca da verdade no Processo Penal. São Paulo: Revista dos Tribunais, 2002, p. 286). Nessa linha, ver BADARÓ, Gustavo Henrique Righi Ivahy, Ônus da prova..., pp. 31/36. A verdade processual é aquela "perseguida pelo modelo formalista como fundamento de uma condenação e que só pode ser alcançada mediante o respeito das regras precisas e relativas aos fatos e circunstâncias considerados como penalmente relevantes” (LOPES Jr., Aury, Direito Processual Penal..., p. 522).

${ }^{173}$ A iniciativa instrutória..., p. 181.

${ }^{174}$ Importante aspecto relacionado à atuação probatória do Juiz é que ela deve ocorrer de modo excepcional e subsidiário às partes, pois "se o magistrado atua de forma a determinar a produção da prova quando está em dúvida, sua atitude viola, então, o princípio da presunção de inocência. Com efeito, havendo dúvida razoável, a atitude do magistrado deve ser no sentido de absolvição e não de substituição do papel do acusador" (DEZEM, Guilherme Madeira. Da prova penal: tipo processual, provas típicas e atípicas. Campinas: Millennium, 2008, p. 103).

${ }^{175}$ GRINOVER, Ada Pellegrini, “A iniciativa instrutória do Juiz no processo penal acusatório”..., p. 73.

176 “Provas - Lei 11.690, de 09.06.2008”..., p. 260. Por isso, segundo o autor, a Lei n. ${ }^{\circ} 11.690 / 08$ não atribuiu poderes de investigação ao juiz penal.

${ }_{177}$ Nesse sentido, conferir BADARÓ, Gustavo Henrique Righi Ivahy, Ônus da prova..., pp. 119/25 e 167/68. Segundo o autor, "partindo da distinção entre fontes de prova e meios de prova, percebe-se, facilmente, que 
Ada Pellegrini Grinover elucida a diferença de atuação do Magistrado nas duas fases da persecução penal, verbis: “a questão que envolve os elementos probatórios colhidos durante a investigação e sua inidoneidade para servir de base para a formação do convencimento do juiz é estranha à problemática da iniciativa instrutória oficial. Esta se circunscreve ao processo, o qual é instaurado após acusação formal do Ministério Público (ou do querelante, seu substituto processual, na ação penal de iniciativa privada). Não se confunda o que se disse quanto aos poderes do juiz no processo e à sua iniciativa probatória com a atribuição de poderes para buscar elementos probatórios durante a fase de investigação prévia. Esta não pode ser confiada ao juiz, sob pena de se retornar ao juizinquisidor do modelo antigo. Durante a investigação, o juiz do processo acusatório tem apenas a função de determinar providências cautelares. Por isso, é oportuno que o juiz da investigação prévia (a cargo do Ministério Público e/ou da polícia judiciária) seja diverso do juiz do processo. É neste, e somente neste, que deve ser estimulada a iniciativa oficial”. 178

Sendo assim, é inaceitável a atividade investigatória do Juiz, porque implica exame precipitado da imputação e tem o condão de ferir a sua imparcialidade como órgão julgador.

\section{III.6.4. Vítima}

A vítima é o sujeito passivo do crime, ou seja, o titular do interesse específico resguardado pelo tipo penal que foi violado pela conduta ilícita. Durante a evolução histórica do processo criminal, houve sensível alteração na posição da vítima, sendo possível identificar três grandes fases: (i) época da vingança privada e da justiça privada, nos primórdios da civilização; (ii) período de esquecimento da vítima, que se iniciou na

perigo para a imparcialidade está no juiz que é um pesquisador, um ‘buscador’ de fontes de provas. Já o juiz que, diante da notícia de uma fonte de prova, como a informação de que uma certa pessoa presenciou os fatos, determina a produção do meio de prova necessário - o testemunho - para incorporar ao processo as informações contidas na fonte de prova, não está comprometido com uma hipótese prévia, não colocando em risco a sua posição de imparcialidade. Ao contrário, o resultado da produção daquele meio de prova pode ser em sentido positivo ou negativo, quanto à ocorrência do fato" (Ibid., pp. 119/20).

178 “A iniciativa instrutória do Juiz no processo penal acusatório"..., p. 75. 
Idade Média e prosseguiu com a edificação do Estado Moderno e (iii) época de redescobrimento da vítima, a partir do século $\mathrm{XX}{ }^{179}$

Nos dias atuais, procura-se prestigiar cada vez mais a vítima, que, tal como o acusado, deixou de ser vista como mero objeto do processo e tornou-se sujeito de direitos e obrigações. Por conseguinte, a vítima tem o direito de participar ativamente da persecução penal.

Na fase de instrução preliminar, a colaboração da vítima é fundamental para a apuração da conduta delitiva, pois, além da sua oitiva ser importante meio de prova, vários atos dependem da sua presença pessoal (acareação, reconhecimento pessoal ou de coisas, reconstituição, exame de corpo de delito etc.). ${ }^{180}$

Além disso, existem outras duas razões que levam à intervenção do ofendido no inquérito policial. A uma, auxiliar na coleta dos elementos informativos necessários para embasar a opinio delicti: seja a sua própria, nos casos em que possui legitimação processual para iniciar a ação penal; ${ }^{181}$ ou a do Ministério Público, se for crime perseguido mediante ação penal pública. ${ }^{182}$ A duas, garantir a reparação do dano causado pela prática delitiva.

O primeiro motivo, de natureza claramente penal, diz respeito ao desejo da vítima de responsabilizar criminalmente o autor do delito, vendo-o ser processado e apenado de forma proporcional à gravidade de sua conduta. Para tanto, costuma ser necessária a instauração de inquérito policial, o que pode ser feito a pedido da própria vítima, nos termos do artigo $5^{\circ}$, II e $\S \S 4^{\circ}$ e $5^{\circ}$, do Código de Processo Penal.

\footnotetext{
${ }^{179}$ A evolução histórica do tratamento da vítima no processo penal é esquadrinhada, com minúcia, por Antonio Scarance Fernandes: O papel da vítima no processo criminal. São Paulo: Malheiros, 1995, pp. $12 / 23$.

${ }^{180}$ Disserta Antonio Scarance Fernandes que "o próprio sucesso da investigação e, conseqüentemente, o bom resultado final do processo dependem muito do interesse da vítima em colaborar. É ela quase sempre quem comunica o crime e indica as principais testemunhas. O seu retorno para prestar ou fornecer novos esclarecimentos é de máxima importância. A sua participação é necessária para a realização de diligências relevantes, tais como os reconhecimentos de coisas e pessoas e a elaboração do exame de corpo de delito" (Ibid., pp. 59/60).

${ }^{181}$ Ação penal privada subsidiária da pública (artigo 29 do Código de Processo Penal) e ação penal de iniciativa privada propriamente dita (artigo 30 do Código de Processo Penal).

${ }^{182} \mathrm{O}$ artigo 24 do Código de Processo Penal prevê a legitimidade do Ministério Público para promover a ação penal. O ofendido, no curso do processo, pode requerer o seu ingresso como assistente de acusação, nos termos dos artigos 268 e seguintes do Código de Processo Penal.
} 
Além disso, a vítima pode atuar ao longo da investigação preliminar, requerendo diligências à Autoridade Policial, conforme previsto no artigo 14 do Código de Processo Penal.

De acordo com o texto legal, a realização da diligência ficaria a critério da Autoridade Policial. Contudo, parece evidente que, uma vez demonstrada a pertinência e relevância do requerimento, a Autoridade Policial tem o dever de atendê-lo, sob pena de embaraçar o direito de prova da vítima e ferir a igualdade entre as partes. Afinal, tanto o imputado quanto o ofendido e o Ministério Público devem ter as mesmas possibilidades para demonstrar as suas teses.

Ademais, a participação do ofendido serve para aumentar a eficiência da investigação criminal, pois somente ele pode fornecer alguns dados essenciais à elucidação do crime. “Assim, só devem ser indeferidos seus requerimentos quando forem realmente desnecessários ou, no caso, implicarem inadequado atraso ou desvio no caminho da investigação”. 183

O segundo motivo, de natureza civil, refere-se ao interesse da vítima de ser ressarcida de todos os prejuízos materiais - e até mesmo morais - provocados pela conduta criminosa. ${ }^{184}$ Esta reparação pode se concretizar por meio da execução, no âmbito civil, da sentença penal transitada em julgado; ${ }^{185}$ ou, ainda, por meio de composição civil ou transação penal (em que se condicione a reparação do dano), nas hipóteses de delitos de menor lesividade. ${ }^{186}$

Especialmente nos casos de infrações de menor potencial, priorizou-se a reparação do dano sofrido pela vítima, o que, segundo o artigo 62 da Lei n. ${ }^{\circ}$ 9.099, de 26 de setembro de 1995, é uma das metas a ser alcançada pelo processo de competência do

\footnotetext{
183 SCARANCE FERNANDES, Antonio, O papel da vítima..., p. 75.

184 Segundo Claus Roxin, atualmente discute-se na Alemanha formas de estimular a reparação do dano sofrido pela vítima por parte do autor do fato. Nesse sentido, uma das soluções aventadas é a descriminalização de certas condutas típicas mediante a reparação do dano (ROXIN, Claus, Pasado, presente y futuro..., pp. 81/83).

${ }^{185} \mathrm{O}$ artigo 475-N, II, do Código de Processo Civil, considera a sentença penal condenatória transitada em julgado como título executivo judicial.

${ }^{186}$ Conforme prescrito nos artigos 72 e seguintes da Lei n. ${ }^{\circ}$ 9.099/95.
} 
Juizado Especial Criminal. Tal previsão legal foi elogiada pela doutrina pátria, por demonstrar preocupação com a situação da vítima na persecução penal. ${ }^{187}$

Justamente com o propósito de assegurar essa compensação material para a vítima, o legislador previu medidas cautelares patrimoniais, a saber: apreensão, seqüestro, especialização da hipoteca legal e arresto. Tais providências podem ser requeridas pelo próprio ofendido e visam impedir a deterioração do patrimônio do acusado, garantindo, com isso, a reparação do dano.

No inquérito policial, em particular, é possível a apreensão, o seqüestro e o arresto prévio. A apreensão consiste em retirar determinado bem da posse do acusado, restringindo-lhe o uso e a disposição. Já o seqüestro é uma medida que incide sobre bens móveis ou imóveis do acusado, adquiridos com os proventos da infração. O arresto prévio, por sua vez, recai sobre bem imóvel do acusado, enquanto não puder ser feita a especialização da hipoteca legal. ${ }^{188}$

Por fim, a Lei n. ${ }^{\circ}$ 11.690/08 alterou o artigo 201 do Código de Processo Penal, que cuida do ofendido e é aplicável analogicamente à investigação preliminar. O $\S 2^{\circ}$ do referido artigo previu a obrigação de informar o ofendido sobre os atos processuais relativos ao ingresso e à saída do acusado da prisão.

O legislador também demonstrou preocupação em proteger a intimidade, vida privada, honra e imagem da vítima - direitos individuais prescritos no artigo $5^{\circ}$, incisos $\mathrm{V}$ e X, da Constituição da República - e fez constar norma expressa nesse sentido: “O juiz tomará as providências necessárias à preservação da intimidade, vida privada, honra e

187 GRINOVER, Ada Pellegrini; SCARANCE FERNANDES, Antonio; GOMES FILHO, Antonio Magalhães e GOMES, Luiz Flávio. Juizados Especiais Criminais. $3^{a}$ ed.. São Paulo: Revista dos Tribunais, 2000, p. 76. Salientam os autores que, em vários pontos, a lei prestigiou a vítima, litteris: “Não chegou a prever a cumulação de ações civil e penal no processo criminal, cuja eficácia é duvidosa, mas aproximou a questão civil da penal, permitindo que na fase preliminar possa ser feito acordo sobre a reparação do dano no Juizado Criminal, com a formação de título executivo. Deu também papel de relevo à vítima, ao prever o acordo civil e, por isso, estimular a sua presença na fase preliminar” (Ibid, p. 76). Ver, também, TOURINHO FILHO, Fernando da Costa. Comentários à Lei dos Juizados Especiais Criminais. 4a ed.. São Paulo: Saraiva, 2007, pp. 40/42.

${ }^{188}$ A apreensão está disciplinada nos artigos 118 a 124 e 240 e seguintes do Código de Processo Penal, sendo que os primeiros tratam, especificamente, da restituição das coisas apreendidas. O seqüestro consta dos artigos 125 a 133 do Código de Processo Penal, enquanto o arresto prévio está regulado no artigo 136 do Código de Processo Penal. Sobre a matéria, conferir: SAAD, Marta. As medidas assecuratórias do Código de Processo Penal como forma de tutela cautelar destinada à reparação do dano causado pelo delito. Tese de doutorado defendida perante a Faculdade de Direito da Universidade de São Paulo em 04 de maio de 2007; e SCARANCE FERNANDES, Antonio, O papel da vítima..., pp. 191/204. 
imagem do ofendido, podendo, inclusive, determinar o segredo de justiça em relação aos dados, depoimentos e outras informações constantes dos autos a seu respeito para evitar sua exposição aos meios de comunicação” (Artigo 201, §6º , do Código de Processo Penal). ${ }^{189}$

III.6.5. Imputado

Como salientado, o inquérito policial, regulamentado por uma legislação retrógrada e reacionária, deve ser examinado a partir de uma leitura constitucional. Assim, ante a existência de diversos direitos e garantias fundamentais positivadas na Constituição da República, que resguardam a posição do indivíduo frente ao Estado, o imputado deve ser tratado como sujeito de direitos e não mais como mero objeto da instrução preliminar. $^{190}$

Por conseqüência, a Autoridade Policial deve explicitar a qualidade em que a pessoa presta declarações nos autos do inquérito policial: como testemunha, suspeito ou indiciado. Definida a situação do sujeito passivo, devem lhe ser asseguradas as prerrogativas previstas na Constituição e em lei.

\footnotetext{
${ }^{189}$ No mesmo sentido, já existia o artigo 11 da Portaria DGP n. ${ }^{\circ}$ 18/98, verbis: “Art. 11 - As autoridades policiais e demais servidores zelarão pela preservação dos direitos à imagem, ao nome, à privacidade e à intimidade das pessoas submetidas à investigação policial, detidas em razão da prática de infração penal ou à sua disposição na condição de vítimas, em especial enquanto se encontrarem no recinto das repartições policiais, a fim de que a elas e a seus familiares não sejam causados prejuízos irreparáveis, decorrentes da exposição de imagem ou de divulgação liminar de circunstância objeto de apuração.

Parágrafo único - As pessoas referidas nesse artigo, após orientadas sobre seus direitos constitucionais, somente serão fotografadas, entrevistadas ou terão suas imagens por qualquer meio registradas, se expressamente consentirem mediante manifestação explícita de vontade, por escrito ou por termo devidamente assinado, observando-se ainda às correlatas normas aditadas pelos Juízos Corregedores da Polícia Judiciária das Comarcas”.

${ }^{190}$ Antes do advento da atual Carta Magna, grande parte da doutrina nacional via o imputado como objeto de investigação, desprovido de direitos, podendo se voltar apenas contra eventuais abusos que atingissem o seu status libertatis. Por todos, recorde-se o magistério de José Frederico Marques, litteris:

"Em face da polícia, o indiciado é apenas objeto de pesquisas e investigações, porquanto ela representa o Estado como titular do direito de punir, e não o Estado como juiz.

(...)

Em todas essas hipóteses, quer agindo discricionariamente, quer atuando estritamente vinculada à lei, mantém a autoridade policial ao réu, como objeto de investigações, e não como sujeito ou titular de direitos. O que o indiciado pode exigir é tão-só que lhe seja respeitado o status libertatis, de forma que é vedado à polícia, fora dos casos estritamente legais, prender o réu ou recusar-lhe fiança" (Elementos..., pp. 149/50).

Atualmente, vê-se o imputado como "sujeito ou titular de direitos, sujeito do procedimento e não apenas sujeito ao procedimento, verdadeiro 'titular de direitos que dentro dele exerce'. O indivíduo é, aliás, sujeito e titular de direitos sempre, não importa em que estágio o procedimento se encontre. Os direitos e as garantias
} 
Note-se que o legislador brasileiro empregou, de maneira indiscriminada e às vezes equivocada, os vocábulos indiciado, acusado e réu, para se referir às diferentes denominações do sujeito passivo da persecução penal. ${ }^{191}$ Tais termos possuem acepções distintas, que refletem os vários níveis de direitos e obrigações do sujeito passivo, conforme os diversos momentos da persecução criminal.

Indiciado é a pessoa que se encontra formalmente submetida ao inquérito policial e contra quem existem indícios de autoria delitiva. ${ }^{192}$ A partir do momento em que há o recebimento da inicial acusatória pelo Juiz e instaura-se o processo criminal, surge a figura do acusado ou réu. ${ }^{193}$

O legislador brasileiro costuma tratar o sujeito passivo do inquérito policial como indiciado, distinguindo-o do suspeito. Nesta hipótese, há mero juízo de possibilidade da autoria, pois ainda não foram reunidos elementos suficientes para determiná-la. Por sua vez, no caso do indiciado, há juízo de probabilidade da autoria, decorrente dos indícios obtidos na investigação. ${ }^{194}$

O indiciamento é forma ampla de imputação, isto é, de atribuição a alguém de um fato penalmente relevante. Assevera Antonio Scarance Fernandes que "não há sentido em limitar-se a imputação à fase processual, sendo de máxima importância em um Estado democrático, assegurar à pessoa considerada a provável autora da infração penal meios de atuar em sua defesa”. 195

constitucionais não têm limites especiais nem obedecem a procedimentos, simplesmente devem ser obedecidos sempre” (SAAD, Marta, O direito de defesa..., pp. 205/06).

${ }^{191}$ O Código de Processo Penal faz menção aos termos acusado e réu antes mesmo de se iniciar a fase processual (por exemplo: artigos 41 e 46 do Código de Processo Penal). Também a expressão indiciado é empregada de maneira inapropriada, provavelmente porque inexiste disciplina legal do indiciamento (por exemplo: artigo $5^{\circ}, \S 1^{\circ}, b$, do Código de Processo Penal).

192 "Indício é todo rastro, vestígio, sinal e, em geral, todo fato conhecido, devidamente provado, suscetível de conduzir ao conhecimento de um fato desconhecido, a ele relacionado, por meio de um raciocínio indutivodedutivo" (MOURA, Maria Thereza Rocha de Assim. A prova por indícios no processo penal. São Paulo: Saraiva, 1994, p. 38).

${ }^{193}$ Para Aury Lopes Jr., "são três os principais momentos no processo penal que atribuem ao sujeito passivo distintas cargas e direitos, devendo ser reconhecido que, em cada um destes momentos, o sujeito passivo possui um status jurídico distinto. Destarte, às três fases (instrução preliminar, fase processual e execução da sentença) correspondem três denominações distintas (imputado ou indiciado; acusado, processado ou réu; condenado ou apenado)" (Sistemas..., p. 286).

${ }^{194}$ Como mencionado, o juízo provável, necessário para o indiciamento, é aneutral, distinguindo-se do juízo possível, que é neutral (PITOMBO, Sérgio Marcos de Moraes, "O indiciamento como ato de Polícia Judiciária”..., p. 314).

${ }^{195}$ SCARANCE FERNANDES, Antonio, Reação Defensiva..., p. 104. 
O autor salienta que a imputação só pode ser realizada por autoridade prevista em lei, após juízo de valor sobre a base indiciária existente nos autos. Por isso, o simples fato de alguém ser indicado em notícia de crime, elaborada por qualquer do povo, não significa imputação. ${ }^{196}$

Por conseguinte, o indiciamento deve ser feito por autoridade pública com expressos poderes para tanto. No Brasil, tal função cabe ao Delegado de Polícia, por ser o responsável pela condução da instrução prévia. ${ }^{197}$

A Autoridade Policial deve providenciar o indiciamento a partir do momento em que forem reunidos indícios suficientes de autoria da infração penal. Não se trata, portanto, de poder discricionário, pois "se o conjunto probatório incrimina o suspeito, revelando que sua conduta se desenha típica, antijurídica e culpável, deve ser indiciado”. ${ }^{198}$

Em síntese, conceitua-se o indiciamento como "o resultado concreto da convergência de indícios que apontam determinada pessoa ou determinadas pessoas como praticantes de ato ou atos tidos pela legislação penal em vigor como típicos, antijurídicos e culpáveis”. 199

É inegável que o indiciamento é um ato de extrema relevância para o imputado, pois é a partir dele que o sujeito passivo torna-se detentor de direitos e deveres no inquérito policial.

No entanto, o Código de Processo Penal não cuida desse ato, isto é, não define o modo e o momento em que deve ocorrer o indiciamento e nem as suas conseqüências

\footnotetext{
${ }^{196}$ Ibid., p. 105.

${ }^{197}$ Excepcionalmente, o indiciamento poderá ser realizado por autoridade diversa da Policial, como em caso de prerrogativa de foro. Nesse sentido, o Supremo Tribunal Federal, em inquérito envolvendo Senador da República, já decidiu que "a Polícia Federal não está autorizada a abrir de ofício inquérito policial para apurar a conduta de parlamentares federais ou do próprio Presidente da República” (STF, Pet.-QO n. ${ }^{\circ}$ 3825/MT, Rel. para acórdão Min. Gilmar Mendes, j. 10.10.2007). É que, nessa hipótese, há a competência originária do STF para apreciação do caso, cabendo à Procuradoria da República a iniciativa do procedimento investigatório, sob a supervisão do Ministro-Relator da Suprema Corte.

${ }_{198}$ PITOMBO, Sérgio Marcos de Moraes, Inquérito..., p. 40. Em outra oportunidade, asseverou o autor que “o indiciar alguém como parece claro, não há de surgir qual ato arbitrário da autoridade, mas legítimo. Não se funda, também, no uso de poder discricionário, visto que inexiste a possibilidade legal de escolher entre indiciar ou não. A questão situa-se na legalidade do ato.

O suspeito, sobre o qual se reuniu prova da autoria da infração, tem que ser indiciado. Já aquele que contra si possui frágeis indícios, ou outro meio de prova esgarçado, não pode ser indiciado. Mantém-se ele como é: suspeito" (PITOMBO, Sérgio Marcos de Moraes, "O indiciamento como ato de Polícia Judiciária”..., pp. 313/14).
} 
jurídicas. Tal fato gera sérios prejuízos ao imputado, pois a sua situação jurídica fica completamente dependente do arbítrio da Autoridade Policial. Por conta da omissão legislativa, não é raro a Autoridade Policial deixar de proceder ao indiciamento para tolher direitos do imputado, como o de permanecer em silêncio e o de não se auto-incriminar. ${ }^{200}$

A doutrina pátria vem chamando a atenção para esse problema e seus efeitos negativos para o imputado. Se o indiciamento fosse devidamente regulado em lei, “poderia se pôr fim a uma das artimanhas muitas vezes utilizadas pelas autoridades que conduzem o inquérito policial, que deixam de indiciar o suspeito, quando deveriam fazê-lo, apenas para tolher-lhe o direito de defesa. Se isso ocorresse em um sistema que trouxesse fixado o momento, a forma e as conseqüências do indiciamento, as decorrências da desídia em não indiciar o indivíduo levariam a que toda prova produzida posteriormente a tal situação de fato se tornasse ilegítima”. ${ }^{201}$

Dessarte, é de extrema importância definir o instante, dentro do inquérito policial, em que o sujeito passivo deixa de ser tratado como mero suspeito e assume a posição de indiciado.

A partir do conceito de indiciamento antes referido, é possível deduzir que tal providência deve ser ultimada pela Autoridade Policial sempre que convergirem elementos de convicção aptos a formar juízo de probabilidade acerca da autoria.

Assim, deve ocorrer o indiciamento se houver detenção cautelar (flagrante delito, temporária ou preventiva) ou alguma providência restritiva de direitos individuais do imputado (busca e apreensão, quebra de sigilo de dados ou das comunicações telefônicas, arresto ou seqüestro de bens etc.). É que, nesses casos, há a atribuição da conduta criminosa a pessoa determinada.

O indiciamento não pode ficar ao alvedrio da Autoridade Policial. O sujeito passivo da persecução prévia deve ser tratado como indiciado, com os direitos e deveres

${ }^{199}$ TUCCI, Rogério Lauria. "Indiciamento e Qualificação Indireta” in Revista dos Tribunais, n. ${ }^{\text {5 571, maio de }}$ 1983, p. 292.

${ }^{200}$ Destaca Antonio Scarance Fernandes que "a falta de indiciamento, contudo, não representa para a pessoa a certeza de que está sendo inquirida como testemunha; pode a autoridade deixar de realizar o indiciamento formal a fim de impedir o suspeito de exercitar os direitos reservados ao indiciado, mas, na realidade, atribui à pessoa a prática da infração, como se constata pela própria maneira como a autoridade conduz a investigação e ela é tratada. Neste caso, a pessoa tem o direito de requerer que seja ouvida como indiciada, podendo utilizar, por exemplo, o direito ao silêncio" (Reação Defensiva..., p. 125). 
inerentes a essa condição, se existirem indícios convergentes da provável autoria delitiva, independentemente de manifestação formal da Autoridade Policial nesse sentido. ${ }^{202}$

Com o objetivo de preencher a lacuna legislativa sobre o indiciamento, está em tramitação o Projeto de Lei n. ${ }^{\circ}$ 4.209/01, que confere nova redação ao artigo $8^{\circ}$ do Código de Processo Penal, regulando expressamente o indiciamento. Tal providência deverá ser efetivada pela Autoridade Policial, motivadamente, quando forem reunidos os elementos informativos tidos como suficientes. A Autoridade Policial deverá dar ciência deste ato ao imputado, assegurando-lhe as garantias decorrentes da situação jurídica de indiciado. ${ }^{203}$

Vale lembrar que, no Estado de São Paulo, o indiciamento é regulamentado, administrativamente, por meio da Portaria n. ${ }^{\circ}$ 18, de 25 de novembro de 1998, expedida pela Delegacia Geral de Polícia.

Tal Portaria dispõe sobre medidas e cautelas a serem adotadas na elaboração de inquéritos policiais. No tocante ao indiciamento, o texto da Portaria é bastante similar ao do mencionado Projeto de Lei, prevendo o seguinte: "logo que reúna, no curso das investigações, elementos suficientes acerca da autoria da infração penal, a autoridade policial procederá ao formal indiciamento do suspeito, decidindo, outrossim, em sendo o

\footnotetext{
${ }^{201}$ SAAD, Marta, O direito de defesa..., pp. 257/58.

${ }^{202}$ É o que se denomina indiciamento de fato. Marta Saad lembra que a qualidade de indiciado de fato é reconhecida pela legislação de diversos países (Ibid., pp. 266/68). Na Itália, para que uma pessoa seja considerada investigada, basta a existência de elementos objetivos no sentido de que a investigação dirige-se contra ela, sendo desnecessário qualquer ato formal (artigo 335 do Código de Processo Penal). Além disso, o artigo 61 do Código de Processo Penal previu expressamente que os direitos e garantias do imputato (equivalente ao nosso indiciado) aplicam-se também à persona sottoposta alle indagini preliminari (equivalente ao nosso investigado/suspeito). Em Portugal, desde o início da investigação preliminar, o sujeito passivo assume a condição de argüido, com seus respectivos direitos e deveres, que mantém ao longo de toda a persecução penal (artigo 57 do Código de Processo Penal). Na Espanha, o artigo 118, da Ley de Enjuiciamiento Criminal, prevê que toda pessoa a quem se impute um fato punível poderá exercitar o direito de defesa, a partir do momento em que lhe é comunicada a sua existência ou tenha sido objeto de detenção ou de qualquer outra medida cautelar.

203 Projeto de Lei n. ${ }^{\circ}$ 4.209/01: “Art. 8. Reunidos os elementos informativos tidos como suficientes, a autoridade policial cientificará o investigado, atribuindo-lhe, fundamentadamente, a situação jurídica de indiciado, com as garantias dela decorrentes.

$\S 1^{\circ} \mathrm{O}$ indiciado, comparecendo, será interrogado com expressa observância das garantias constitucionais e legais.

$\S 2^{\circ} \mathrm{O}$ indiciado será identificado datiloscopicamente nas hipóteses previstas em lei.

$\S 3^{\circ} \mathrm{A}$ autoridade policial deverá colher informações sobre a vida pregressa do indiciado, sob o ponto de vista individual, familiar e social, sua condição econômica, e outros dados que contribuam para a verificação de sua personalidade.

$\S 4^{\circ}$ A autoridade deverá informar ao indiciado a importância do endereço por ele fornecido, para efeito de citação e intimação, bem como sobre o dever de comunicar qualquer mudança de endereço”.
} 
caso, pela realização da sua identificação pelo processo dactiloscópico” (artigo $5^{\circ}$ da Portaria DGP n. ${ }^{0}$ 18/98).

A Portaria dedicou especial atenção à motivação do indiciamento. Segundo o parágrafo único do aludido artigo $5^{\circ}$, o indiciamento deve ser precedido de despacho fundamentado da Autoridade Policial, indicando, com base nos elementos probatórios reunidos na investigação, os motivos de sua convicção quanto à autoria delitiva e à classificação infracional atribuída ao fato.

Reitere-se que, a partir do indiciamento, o imputado sujeita-se com maior intensidade aos atos investigatórios, tais como medidas restritivas pessoais e patrimoniais, interrogatório, acareações etc.. Em contrapartida, desfruta de uma série de direitos, dentre os quais se destacam aqueles previstos no artigo $5^{\circ}$ da Constituição da República (como, por exemplo, direito a não ser submetido a tratamento desumano ou degradante; direito à integridade física e moral; direito de defesa; direito a ter conhecimento dos motivos da prisão e da autoridade que a realizou etc.).

Antonio Scarance Fernandes ${ }^{204}$ sintetiza os principais direitos do imputado na fase pré-processual, a saber: (i) ter ciência da imputação; (ii) ser ouvido sobre a imputação; (iii) ter conhecimento do proceder investigatório; e (iv) apresentar, por si ou por defensor, dados que possam influir no andamento da investigação, no oferecimento da denúncia e na análise da viabilidade de futura acusação. ${ }^{205}$

Merece especial atenção o direito de defesa, que se desdobra em defesa técnica (assistência jurídica) e autodefesa. Esta pode ser positiva (participação ativa do indiciado no inquérito policial) ou negativa (direito ao silêncio e de não produzir prova contra si mesmo).

Sobre a necessidade do direito de defesa na fase investigatória, em especial a defesa técnica, afirma Marta Saad: "É preciso, pois, garantir a defesa efetiva do acusado quando esta realmente importa, estendendo-se o exercício do direito de defesa ao inquérito

\footnotetext{
${ }^{204}$ Reação Defensiva..., p. 113.

205 Salienta Joaquim Canuto Mendes de Almeida que “quem quer que seja indiciado, pois, em inquérito policial, preso, conduzido, ou espontaneamente presente, tem direito a exigir que a autoridade o interrogue, forme o corpo de delito, realize quaisquer perícias necessárias ao esclarecimento da verdade, ouça o ofendido, inquira testemunhas por ele apontadas, desde que indispensáveis ou úteis à elucidação das circunstâncias do fato, junte documentos nos autos, etc.” (Princípios..., p. 213).
} 
policial. Mas não só a autodefesa, insuficiente em face do próprio comprometimento emocional e do desconhecimento técnico do acusado. Este deve poder contar, pois, com assistência de advogado, legalmente habilitado, zeloso e competente, na real defesa dos interesses de sua liberdade jurídica”. 206

Nesse sentido, vale lembrar que a Lei n. ${ }^{\circ}$ 11.449, de 15 de janeiro de 2007, que alterou a redação do artigo 306 do Código de Processo Penal, tornou obrigatória a remessa de fotocópia integral dos autos do inquérito policial para a Defensoria Pública, nos casos em que o imputado não possui advogado nomeado. ${ }^{207}$ Tal dispositivo revela a intenção do legislador pátrio de garantir defesa técnica ao imputado durante a persecução prévia.

Apesar de se discutir a incidência do contraditório e da ampla defesa no inquérito policial, não há dúvida de que o indiciamento representa imputação criminal em face de certa pessoa. Por isso, já na fase investigatória, o indiciado tem o direito, ainda que limitado, de se defender e provar sua inocência, como será examinado, mais profundamente, no próximo capítulo.

\footnotetext{
${ }^{206}$ O direito de defesa..., p. 202.

207 “Art. 306. A prisão de qualquer pessoa e o local onde se encontre serão comunicados imediatamente ao juiz competente e à família do preso ou a pessoa por ele indicada.

$\S 1^{\circ}$ Dentro em 24h (vinte e quatro horas) depois da prisão, será encaminhado ao juiz competente o auto de prisão em flagrante acompanhado de todas as oitivas colhidas e, caso o autuado não informe o nome de seu advogado, cópia integral para a Defensoria Pública.

$\S 2^{\circ}$ No mesmo prazo, será entregue ao preso, mediante recibo, a nota de culpa, assinada pela autoridade, com o motivo da prisão, o nome do condutor e o das testemunhas”.
} 


\section{A INVESTIGAÇÃO CRIMINAL DEFENSIVA COMO GARANTIA DE EQUILÍBRIO ENTRE AS PARTES EM UM PROCESSO PENAL ACUSATÓRIO}

\section{IV.1. Apontamentos sobre os princípios constitucionais da igualdade, do contraditório e da ampla defesa}

Ao longo do tempo, foram concebidos três sistemas processuais penais (acusatório, inquisitório e misto) com características bastante distintas entre si, conforme exposto no item II.3.

O modelo acusatório, que, nos dias de hoje, é referência para a grande maioria dos Estados (ao menos os democráticos), funda-se na total separação das funções de acusar, defender e julgar, entre sujeitos distintos.

Além da repartição dos poderes processuais, conditio sine qua non para a existência do sistema acusatório, é possível identificar outras notas características: (i) ativação da causa pelas partes; (ii) independência e imparcialidade do Juiz; (iii) liberdade de defesa e igualdade de posição entre as partes; (iv) contraditório; (v) publicidade e oralidade do procedimento; (vi) presunção de inocência; (vii) livre apresentação de provas pelas partes. ${ }^{208}$

No Brasil, com o advento da Constituição da República de 1988, instituiu-se um processo penal predominantemente acusatório, com a divisão das funções processuais entre diferentes atores. ${ }^{209}$ Ao mesmo tempo, foram preservados certos poderes instrutórios - e não investigatórios - à Autoridade Judiciária (a referida inquisitividade que, como ressaltado, não se choca com o caráter acusatório do sistema).

\footnotetext{
${ }^{208}$ MARQUES, José Frederico, Elementos..., p. 92.

${ }^{209}$ Atualmente, inexistem sistemas acusatórios ou inquisitórios puros. “A análise dos diversos ordenamentos jurídicos demonstra a possibilidade de várias combinações de características dos sistemas acusatório ou inquisitório: ora o processo é prevalentemente acusatório, ora apresenta maiores características inquisitoriais” (BADARÓ, Gustavo Henrique Righi Ivahy, Ônus da prova..., pp. 101/02).
} 
No que mais de perto interessa ao tema da investigação defensiva, passa-se ao exame dos princípios da igualdade, do contraditório e da ampla defesa, corolários do devido processo legal em um sistema processual penal de partes. ${ }^{210}$

\section{IV.1.1. Princípio da igualdade}

Os seres humanos, como é cediço, possuem inúmeros traços físicos e psíquicos que distinguem uns dos outros. Assim, quando se fala em igualdade como princípio constitucional, faz-se referência à equivalência de direitos e sua efetivação e não à nivelação de características da personalidade humana. ${ }^{211}$

Tal postulado está prescrito no artigo $5^{\circ}$, caput, da Constituição da República. $^{212}$ Não se trata de mera igualdade perante a lei (denominada simplesmente isonomia, para alguns, ou isonomia formal, para outros), mas também de igualdade material, isto é, perante o Estado. De fato, “a igualdade, do ponto de vista jurídico, é direito fundamental. Cada um tem direito de não ser discriminado em sua diferença, bem como direito igual de receber, do Estado, oportunidades, bens e serviços. O direito fundamental, porém, não é apenas direito de ser igual perante a lei, mas direito de ser igual aos demais também na ordem social. A igualdade é perante o Estado, e não perante a lei. Não existe mais isonomia formal, a isonomia, hoje, tem conteúdo substancial”. ${ }^{213}$

\footnotetext{
${ }^{210}$ Consoante o artigo 5o , LIV, da Constituição da República, apenas poderá haver privação de liberdade por meio do devido processo legal. Esta garantia pode ser vista sob dois aspectos: de um lado, a indispensabilidade do processo para a aplicação da pena; de outro, a existência de um processo adequado, pautado pelas garantias da igualdade, do contraditório e da ampla defesa (GRECO FILHO, Vicente, Tutela Constitucional..., p. 110).

${ }^{211}$ COSTA, Paula Bajer Fernandes Martins da. Igualdade no direito processual penal brasileiro. São Paulo: Revista dos Tribunais, 2001, p. 21.

${ }^{212}$ Artigo 50 $5^{\circ}$ caput, da Constituição da República: "todos são iguais perante a lei, sem distinção de qualquer natureza, garantindo-se aos brasileiros e aos estrangeiros residentes no País a inviolabilidade do direito à vida, à liberdade, à igualdade, à segurança e à propriedade, nos termos seguintes".

${ }^{213}$ COSTA, Paula Bajer Fernandes Martins da, Igualdade..., pp. 59/60. José Afonso da Silva distingue isonomia formal e material da seguinte forma: "Nossas constituições, desde o império, inscreveram o princípio da igualdade, como igualdade perante a lei, enunciado que, na sua literalidade, se confunde com a mera isonomia formal, no sentido de que a lei e sua aplicação tratam a todos igualmente, sem levar em conta as distinções de grupos. A compreensão do dispositivo vigente, nos termos do art. $5^{\circ}$, caput, não deve ser assim tão estreita. O intérprete há que aferi-lo com outras normas constitucionais, conforme apontamos supra e, especialmente, com as exigências da justiça social, objetivo da ordem econômica e da ordem social. Considerá-lo-emos como isonomia formal para diferenciá-lo da isonomia material, traduzido no art. $7^{\circ}, \mathrm{XXX}$ e XXXI, que já indicamos no n. ${ }^{\circ} 1$ supra.

A Constituição procura aproximar os dois tipos de isonomia, na medida em que não se limitara ao simples enunciado da igualdade perante a lei; menciona também igualdade entre os homens e mulheres e acrescenta
} 
O princípio da igualdade deve ser respeitado tanto pelo legislador quanto pelos aplicadores da norma jurídica. Veda-se a discriminação na fase de elaboração legislativa e durante a aplicação da norma ao caso concreto.

No âmbito processual penal, o princípio da igualdade garante, de um lado, o tratamento paritário aos que se encontram em posição jurídica idêntica no processo e, de outro, as mesmas oportunidades para as partes comprovarem os seus argumentos. ${ }^{214}$

A igualdade justifica e dá valor ao processo criminal e seu procedimento. Apenas com o cumprimento desse postulado é que se pode alcançar a verdade e, por conseguinte, realizar a Justiça penal. ${ }^{215}$

Tal princípio relaciona-se com o contraditório, na medida em que “coloca as duas partes em posição de similitude perante o Estado e, no processo, perante o juiz. Não se confunde com o contraditório, nem o abrange. Apenas se relacionam, pois ao se garantir a ambos os contendores o contraditório também se assegura tratamento igualitário”.216 Tanto que é possível existir contraditório onde há desigualdade. ${ }^{217}$

Para Paula Bajer Fernandes Martins da Costa, ${ }^{218}$ não haveria paridade de armas na persecução penal, pois esta seria marcada por um permanente estado de desigualdade entre as partes, decorrente das providências cautelares que as autoridades públicas podem requerer em face do acusado. Porém, no seu entender, tal desigualdade seria suprida pelo devido processo legal, em particular pela jurisdição e pelo contraditório.

vedações a distinção de qualquer natureza e qualquer forma de discriminação" (Curso de Direito Constitucional Positivo. 14 a ed.. São Paulo: Malheiros, 1997, pp. 209/10).

214 SCARANCE FERNANDES, Antonio, Processo..., p. 46; TUCCI, Rogério Lauria, Direitos e garantias..., p. 164 e FERRAJOLI, Luigi, Direito e razão..., p. 490.

${ }^{215}$ COSTA, Paula Bajer Fernandes Martins da, Igualdade..., pp. 15/16.

216 SCARANCE FERNANDES, Antonio, Processo..., p. 63.

217 DINAMARCO, Cândido Rangel. “O princípio do contraditório” in Revista PGE, São Paulo, n. ${ }^{\circ}$ 19, 1981/82, pp. 29 e segs..

${ }^{218}$ Igualdade..., pp. 90/101. Segundo a autora, “as providências cautelares, possíveis de concretização em toda a persecução penal, inviabilizam a isonomia processual. Nem mesmo por ficção se dirá que o acusado, ainda que representado por advogado, ostenta posição jurídica equivalente à do membro do Ministério Público no processo, ou dispõe das mesmas armas para encontrar a expor a sua verdade. A constante possibilidade de prisão processual, ou outra providência constritiva no curso do processo, ameaça qualquer tentativa de equilíbrio real entre as partes da persecução.

Tratar de paridade de armas, nessas circunstâncias, é ignorar a realidade processual e política de que o sujeito processual vinculado ao Estado tem a possibilidade de requerer uso da força sobre o outro sujeito parcial, que a ela deve se submeter quando ordenada coação pelo Judiciário.

(...) 
Acusador e acusado realmente estão em posições desiguais na persecução penal, pois aquele possui o aparato estatal para ampará-lo, enquanto este deve contar com as suas próprias forças. No entanto, de tal circunstância não se infere a ausência de paridade de armas no processo penal; ao contrário, depreende-se a necessidade de se garantir o equilíbrio de oportunidades entre as partes para demonstrarem as suas teses. Por isso, em algumas situações, pode haver o tratamento diferenciado da parte mais fraca, para compensar a sua posição mais frágil na persecução penal. ${ }^{219}$

Em suma, um processo justo depende de simetria na idoneidade técnica das funções da acusação e da defesa. Para alcançar este propósito, é necessária, às vezes, tutela diferenciada para o direito de defesa do acusado em relação às prerrogativas conferidas à acusação. “Daí a previsão, tanto nos diversos ordenamentos como nos textos internacionais, de certas vantagens à defesa no processo penal, que não configuram indevida distinção, mas, ao contrário, favorecem um equilíbrio global que não desnatura a paridade de armas que decorre do contraditório”. ${ }^{220}$

\section{IV.1.2. Princípios do contraditório e da ampla defesa}

O contraditório, antes de relevante garantia processual, constitui um dos elementos essenciais da definição de processo. "De fato, se na sua acepção lógicofilosófica o contraditório é entendido como o contraste entre posições assertivas opostas, dirigidas a se elidirem reciprocamente, no esquema processual essa contraposição só adquire sentido quando destinada à persuasão de um terceiro imparcial, ainda que não necessariamente inerte ou passivo; assim, embora se desenvolva entre dois pólos dialéticos, o contraditório processual implica uma relação triádica, que constitui afinal a essência da idéia de processo”.221

A paridade de armas não existe no processo penal. Todavia, a igualdade de todos os homens na formulação da lei, e perante a lei, é transmitida ao processo penal, por meio da jurisdição. O devido processo legal supre a ausência de igualdade entre os titulares dos interesses conflitantes” (Ibid., pp. 99/101).

${ }^{219}$ Segundo Antonio Scarance Fernandes, "quando se afirma que as duas partes devem ter tratamento paritário, isso não exclui a possibilidade de, em determinadas situações, dar-se a uma delas tratamento especial para compensar eventuais desigualdades, suprindo-se o desnível da parte inferiorizada, a fim de, justamente, resguardar a paridade de armas. O tratamento diferenciado no processo penal entre acusação e defesa, em favor desta, está justificado por alguns princípios relevantes: in dubio pro reo; favor rei" (Processo..., pp. 49/50). Ver, também, TUCCI, Rogério Lauria, Direitos e garantias..., p. 167.

${ }^{220}$ GOMES FILHO, Antonio Magalhães, A motivação..., p. 43.

${ }^{221}$ Ibid., p. 39. 
Dá-se destaque à função social do contraditório, que serve como fator legitimador da decisão a ser tomada. Vale dizer: a possibilidade de influenciar o resultado do processo é que leva as partes a aceitarem uma solução futura incerta. ${ }^{222}$

No Direito brasileiro, o contraditório surgiu na Constituição da República de 1937 (artigo 122, n. ${ }^{\circ}$ 11, segunda parte) e foi mantido nos textos constitucionais posteriores (artigo 141, §25, da Constituição de 1946; artigo 140, §16, da Constituição de 1967, renumerado na emenda de 1969 para artigo 153, §16).

Hoje, tal postulado está prescrito no artigo $5^{\circ}$, LV, da Constituição da República $^{223}$ e abrange dois aspectos: ciência e participação. O primeiro refere-se à necessidade de se comunicar previamente as partes da realização de um ato processual. O segundo diz respeito à faculdade das partes de participar ativamente dos atos processuais, com o objetivo de influenciar o convencimento do julgador. ${ }^{224}$

Assim, pode-se conceituar o contraditório como o direito de cada uma das partes de ser informado e de participar dos atos processuais, em contraposição aos argumentos sustentados pela outra parte. Ou seja, "a ciência bilateral dos atos e termos processuais e possibilidade de contrariá-los”. 225

O contraditório deve ser respeitado em todos os momentos da atividade probatória: postulação, admissão, produção e valoração. ${ }^{226}$ Salienta Antonio Scarance

\footnotetext{
${ }^{222}$ GOMES FILHO, Antonio Magalhães. Direito à prova no processo penal. São Paulo: Revista dos Tribunais, 1997, p. 136.

${ }^{223}$ Artigo $5^{\circ}$, LV, da Constituição da República: “aos litigantes, em processo judicial ou administrativo, e aos acusados em geral são assegurados o contraditório e ampla defesa, com os meios e recursos a ela inerentes".

${ }^{224}$ Os dois momentos do contraditório são assim elucidados por Antonio Magalhães Gomes Filho: "A primeira manifestação do contraditório e pressuposto básico da referida participação é a informação, uma vez que sem a ciência efetiva a respeito de tudo o que se passa no processo seria inviável o exercício daquele complexo de atividades pelos interessados no provimento. Daí a grande relevância para o contraditório dos atos de comunicação processual (...).

Num segundo momento, de participação ativa propriamente dita, o contraditório engloba um amplo e complexo feixe de prerrogativas, poderes e faculdades utilizadas pelas partes, que convergem para a obtenção de um resultado favorável por intermédio do processo" (A motivação..., pp. 40/41).

${ }^{225}$ ALMEIDA, Joaquim Canuto Mendes de, Princípios..., p. 82.

226 "Especificamente em matéria probatória, o contraditório deve ser rigorosamente observado nos quatro momentos da prova:

$1^{\circ}$ Postulação (denúncia ou resposta escrita): contraditório está na possibilidade de também postular a prova, em igualdade de oportunidades e condições.

$2^{\circ}$ Admissão (pelo juiz): contraditório e direito de defesa concretizam-se na possibilidade de impugnar a decisão que admite a prova.

$3^{\circ}$ Produção (instrução): o contraditório manifesta-se na possibilidade de as partes participarem e assistirem a produção da prova.
} 
Fernandes ${ }^{227}$ que, no processo penal, o contraditório deve ser pleno e efetivo: pleno, porque deve ser observado durante toda a relação jurídico-processual, até o seu final; efetivo, porque devem ser proporcionados à parte meios reais de contrariar os atos de seu oponente.

Por seu turno, a ampla defesa sempre esteve positivada no Direito brasileiro: desde o primeiro texto constitucional (artigo 179, §8 ${ }^{\circ}$, da Constituição de 1824) até o citado artigo 5 , LV, da Constituição da República.

Define-se tal postulado como direito do acusado à tutela jurídica de sua liberdade. Cuida-se, portanto, de “contrariedade à acusação, sua repulsa ou antítese”.228 Assinala Ada Pellegrini Grinover que a ampla defesa não é apenas direito do imputado, mais que isso, é "uma garantia - garantia do acusado, de um lado, e garantia do justo processo, do outro". ${ }^{229}$ Isso porque tem a relevante função social de assegurar regularidade ao procedimento e legitimar a própria jurisdição.

A ampla defesa divide-se em defesa técnica e autodefesa. A primeira consiste na assistência jurídica ao imputado por defensor de sua confiança, sendo considerada indisponível, pois essencial para garantir a igualdade, o contraditório e a imparcialidade do Juízo.

Os artigos 5º, LXIII e LXXIV, e 133, da Constituição da República, previram expressamente a indispensabilidade do defensor técnico, sendo garantida a assistência jurídica aos hipossuficientes. ${ }^{230}$

$4^{\circ}$ Valoração (na sentença): o contraditório manifesta-se através do controle da racionalidade da decisão (externada pela fundamentação) que conduz à possibilidade de impugnação pela via recursal” (LOPES Jr., Aury, Direito Processual Penal..., p. 511).

${ }^{227}$ Processo..., p. 58.

${ }^{228}$ MOURA, Maria Thereza Rocha de Assis e PITOMBO, Cleunice A. Valentim Bastos. "Defesa Penal: Direito ou Garantia” in Revista Brasileira de Ciências Criminais, n. ${ }^{\circ}$ 04, out./dez. de 1993, p. 113. As autoras mencionam que tal direito é comumente classificado pela doutrina em defesa em sentido amplo ou subjetivo e defesa em sentido estrito ou objetivo: a primeira consiste em direito individual, sendo "o ato pelo qual o acusado, pessoalmente, ou por defensor, contraria ou repele a acusação que lhe é feita"; a segunda "é o conjunto de matérias, provas e argumentos que o inculpado aduz a seu favor" (Ibid., p. 114).

229 "As garantias constitucionais do processo" in Novas tendências do direito processual. Rio de Janeiro: Forense Universitária, 1990, p. 08.

230 “Art. 5. (...)

LXIII - o preso será informado de seus direitos, entre os quais o de permanecer calado, sendo-lhe assegurada a assistência da família e do advogado;

(...)

LXXIV - o Estado prestará assistência jurídica integral e gratuita aos que comprovarem insuficiência de recursos”. 
Já a autodefesa é a resistência pessoal do imputado à acusação que lhe foi dirigida e, ao contrário da defesa técnica, é renunciável. Contudo, o Magistrado tem o dever de facultar ao imputado o exercício desse direito.

A autodefesa compõe-se de dois aspectos: o direito de audiência e o direito de presença. “O primeiro traduz-se na possibilidade de o acusado influir sobre a formação do convencimento do juiz mediante o interrogatório. $\mathrm{O}$ segundo manifesta-se pela oportunidade de tomar ele posição, a todo momento, perante as alegações e as provas produzidas, pela imediação com o juiz, as razões e as provas”. ${ }^{231}$

Além disso, a autodefesa pode se manifestar de maneira positiva, se o imputado decidir adotar postura pró-ativa e aduzir os seus argumentos de defesa - o que normalmente ocorre no interrogatório policial ou judicial. Por outro lado, pode ser negativa, se o imputado permanecer silente e não contribuir com a apuração dos fatos. Sob essa ótica, o direito ao silêncio e a não se auto-incriminar constituem corolários da autodefesa.

Vicente Greco Filho ${ }^{232}$ sintetiza os meios inerentes à ampla defesa: (i) ter conhecimento claro da imputação; (ii) poder apresentar alegações contra a acusação; (iii) poder acompanhar a prova produzida e rebatê-la; (iv) ter defesa técnica; e (v) poder recorrer da decisão desfavorável.

O artigo $8^{\circ}$ da Convenção Americana sobre Direitos Humanos (Pacto de São José da Costa Rica) estabelece diversas garantias para o acusado vinculadas ao direito de defesa, a saber: (i) direito de ser ouvido em prazo razoável; (ii) direito de ser assistido gratuitamente por tradutor ou intérprete; (iii) comunicação prévia e pormenorizada da acusação formulada; (iv) concessão de tempo e meios adequados para a preparação da defesa; (v) direito de se defender pessoalmente ou de ser assistido por defensor de sua escolha e de comunicar-se, livremente e em particular, com seu defensor; (vi) direito irrenunciável de ser assistido por defensor proporcionado pelo Estado; (vii) direito de

\footnotetext{
“Art. 133. O advogado é indispensável à administração da justiça, sendo inviolável por seus atos e manifestações no exercício da profissão, nos limites da lei”.

Atualmente, existem dois projetos de lei em tramitação no Congresso Nacional, com o objetivo de regulamentar a assistência do advogado no inquérito policial: Projeto de Lei n. ${ }^{\circ}$ 2.336/2000 e Projeto de Lei n. ${ }^{\circ} 6.556 / 2002$.

231 GRINOVER, Ada Pellegrini; SCARANCE FERNANDES, Antonio e GOMES FILHO, Antonio Magalhães. As nulidades no Processo Penal. 8a ed.. São Paulo: Revista dos Tribunais, 2004, p. 93.
} 
inquirir testemunhas e de obter o seu comparecimento; (viii) direito de não ser obrigado a depor contra si mesmo, nem a se declarar culpado e (ix) direito de recorrer para a superior instância. ${ }^{233}$

Note-se que a ampla defesa e o contraditório estão intimamente relacionados, uma vez que “o processo, pela sua própria natureza, exige partes em posições opostas, uma delas necessariamente em posição de defesa, e para que, no seu desenvolvimento, seja garantida a correta aplicação da Justiça, impõe-se que cada uma tenha o direito de se contrapor aos atos e termos da parte contrária”.234

Fácil perceber o vínculo existente entre os referidos postulados constitucionais, pois é a defesa que afiança o contraditório, ao mesmo tempo em que por este se manifesta e é garantida. É possível dizer que “defesa e contraditório estão indissoluvelmente ligados, porquanto é do contraditório (visto em seu primeiro momento, da informação) que brota o exercício da defesa; mas é essa - como poder correlato ao de ação - que garante o contraditório. A defesa, assim, garante o contraditório, mas também por este se manifesta e é garantida. Eis a íntima relação e interação da defesa e do contraditório”. 235

Apesar da estreita relação, contraditório e defesa são direitos autônomos. Enquanto o primeiro pressupõe partes em sentidos opostos, um sujeito imparcial e o exercício do direito de defesa; este existe independentemente do contraditório. Por isso, João Francisco Pontes de Miranda ${ }^{236}$ afirma que a contraditoriedade processual e o direito de defesa são princípios distintos: este começa antes mesmo de se iniciar aquela e pode persistir, como normalmente persiste, para além dela.

Por tal motivo, sustenta-se a incidência do direito de defesa, mas não do contraditório, no inquérito policial, pois ainda não há acusação formal e partes em sentido estrito.

\footnotetext{
${ }^{232}$ Tutela Constitucional..., p. 110.

${ }^{233}$ Tal Convenção foi aprovada em São José da Costa Rica, em 22 de novembro de 1969, e integrada ao ordenamento jurídico brasileiro por meio do Decreto n. ${ }^{\circ}$ 678, de 06 de novembro de 1992.

${ }^{234}$ SCARANCE FERNANDES, Antonio, Processo..., p. 267.

235 GRINOVER, Ada Pellegrini, et alli, As nulidades..., p. 90.
} 


\section{IV.2. O contraditório e o direito de defesa no inquérito policial}

Antes da promulgação da Constituição da República de 1988, prevalecia o entendimento de que era inadmissível o contraditório e o direito de defesa no inquérito policial, por ser procedimento inquisitório.

Por todos, vale lembrar a lição de José Frederico Marques, um dos juristas que mais se opôs à incidência do contraditório e do direito de defesa no inquérito policial, considerando o imputado mero objeto de investigação. In verbis: “Ao contrário do que pensam alguns, não se deve tolerar um inquérito contraditório, sob pena de fracassarem as investigações policiais, sempre que surja um caso de difícil elucidação. (...) Nesse ponto, foi sábio o Código, deixando à discrição da autoridade que preside o inquérito admitir os depoimentos de testemunhas do réu ou do ofendido. A investigação policial não pode ser tumultuada com a intromissão do indiciado. Somente quando o caso a averiguar é duvidoso, deve a polícia atender aos pedidos de prova formulados pelo réu ou pelo ofendido. A necessidade, porém, de praticar tais atos instrutórios fica entregue à apreciação discricionária da autoridade policial”. ${ }^{237}$

Contrário a essa idéia, Joaquim Canuto Mendes de Almeida reclamou a possibilidade de defesa na fase investigatória, enxergando o imputado como sujeito de direitos: "uma vez que o inquérito policial se destina a servir de base à denúncia ou queixa, a servir de fundamento a um despacho judicial de que resulta para o indiciado o mal do processo, seria absolutamente contrário a qualquer senso de justiça, e ao sistema mesmo de nosso processo penal, afastá-lo, como se nada tivesse ele a ver com sua própria liberdade”. 238

Todavia, ressalvou o jurista que o exercício deste direito de defesa não implica em contraditório, pois, na instrução preliminar, não cabe intervenção ampla das partes, isto é, capaz de vincular o Juiz aos pontos por elas suscitados. ${ }^{239}$

\footnotetext{
${ }^{236}$ Comentários à Constituição de 1967. São Paulo: Revista dos Tribunais, 1967, t. V, p. 208.

${ }^{237}$ Elementos..., p. 151.

${ }^{238}$ Princípios..., p. 217. Essa possibilidade de defesa, segundo o autor, não seria admissível nas diligências investigatórias, que são aquelas que "precedem o registro, no inquérito policial, de cada elemento de convicção real, pessoal ou documental” (Ibid., p. 217).

${ }^{239}$ Ibid., pp. 116/17.
} 
Com a edição do atual texto político, incrementou-se a discussão a respeito da incidência do contraditório e da ampla defesa na fase investigatória, devido à confusa redação do artigo $5^{\circ}, \mathrm{LV}$, verbis: “aos litigantes, em processo judicial ou administrativo, e aos acusados em geral são assegurados o contraditório e ampla defesa, com os meios e recursos a ela inerentes”.

Há quem entenda que a norma constitucional, por mencionar "processo administrativo" e "acusados em geral”, prevê a aplicação dos referidos princípios na fase investigatória. É que a primeira expressão abrangeria o inquérito policial por se tratar de procedimento administrativo pré-processual; enquanto a segunda incluiria as pessoas que sofrem qualquer tipo de imputação criminal, inclusive em sentido amplo, como o indiciamento. $^{240}$

Fauzi Hassan Choukr ${ }^{241}$ resume os argumentos básicos dos defensores do contraditório na investigação: ser esta etapa “processo administrativo”, preparatório ao exercício da ação penal, no qual existiria conflito de interesses e, portanto, litígio e litigantes.

Uma das principais referências dessa corrente é Rogério Lauria Tucci. ${ }^{242}$ A seu ver, uma contraditoriedade efetiva e real em todo o desenrolar da persecução penal, inclusive na fase pré-processual, é indispensável para a concretização do direito de defesa do imputado e para formar o convencimento judicial, pautado pela perquirição da verdade material.

Observa o autor que “a contraditoriedade da investigação criminal consiste num direito fundamental do imputado, direito esse que, por ser 'um elemento decisivo do processo penal', não pode ser transformado, em nenhuma hipótese, em 'mero requisito

\footnotetext{
${ }^{240}$ Nesse sentido, reza Aury Lopes Jr.: “A postura do legislador foi claramente garantista e a confusão terminológica (falar em processo administrativo quando deveria ser procedimento) não pode servir de obstáculo para sua aplicação no inquérito policial. Tampouco pode ser alegado que o fato de mencionar acusados, e não indiciados, é um impedimento para sua aplicação na investigação preliminar. Sucede que a expressão empregada não foi só acusados, mas sim acusados em geral, devendo nela ser compreendida também o indiciamento, pois não deixa de ser uma imputação em sentido amplo". Conclui o autor: "Em suma, entendemos que o art. $5^{\circ}, \mathrm{LV}$, da Constituição não pode ser objeto de uma leitura restritiva, senão que o CPP deve adaptar-se à nova ordem constitucional, admitindo-se a existência de contraditório e defesa no inquérito policial, ainda que com um alcance mais limitado que aquele reconhecido na fase processual, atendendo às especiais particularidades da investigação preliminar” (LOPES Jr., Aury, Sistemas..., pp. 309/11).

${ }^{241}$ Garantias Constitucionais..., p. 126.

242 TUCCI, Rogério Lauria, Direitos e garantias..., pp. 221 e seguintes.
} 
formal'; e cuja observância, por isso, se impõe, sob pena de nulidade dos atos procedimentais praticados sem a efetiva assistência do defensor técnico constituído pelo indiciado, ou público (cf., também, arts. 5º LXXIV, e 134 da CF)”.243

O direito de defesa, em seus dois aspectos de defesa técnica e autodefesa, também incidiria na fase investigatória, encontrando respaldo não só no texto constitucional, mas também no artigo 14 do Código de Processo Penal, que permite a requisição de diligências pelo indiciado.

Outra parte dos doutrinadores brasileiros refuta a idéia de contraditório no inquérito policial, pois a referida norma constitucional não autorizaria essa extensão e tal postulado seria exclusivo da relação jurídico-processual.

Nessa linha, argumenta-se que inexiste acusado no inquérito policial, pois ainda não se instaurou conflito de interesses entre partes contrapostas. Ademais, o inquérito policial não constitui "processo judicial ou administrativo”, como menciona o artigo 5 ${ }^{\circ}$ LV, da Constituição da República.

Esta corrente não contesta o fato de o imputado deter, em certa medida, direito de defesa, já que sofre imputação em sentido amplo e, atualmente, é visto como sujeito de direitos e não mero objeto da investigação. ${ }^{244}$ Reforça a necessidade de direito de defesa, na persecução preliminar, o fato de que, nesta fase, podem ser obtidos meios de prova definitivos, que embasarão eventual acusação ou provimentos cautelares restritivos de direitos individuais. ${ }^{245}$

\footnotetext{
${ }^{243}$ Ibid., pp. 389/90.

${ }^{244}$ ALMEIDA, Joaquim Canuto Mendes de, Princípios..., p. 217; e PITOMBO, Sérgio Marcos de Moraes. "Inquérito policial: exercício do direito de defesa" in Boletim do Instituto Brasileiro de Ciências Criminais, n. ${ }^{\circ}$ 83, edição especial, outubro/1999, p. 14. Para Antonio Scarance Fernandes, "há, sem dúvida, necessidade de se admitir a atuação da defesa na investigação, ainda que não se exija o contraditório, ou seja, ainda que não se imponha a necessidade de prévia intimação dos atos a serem realizados” (Processo..., pp. 64/65). De igual maneira, aduz Marta Saad que "é de se reconhecer que já há acusação, em senso largo, entendida como 'afirmação, ou atribuição de ato ou fato a pessoa autora, coatora ou partícipe', em diversos atos do inquérito policial, como na prisão em flagrante delito; na nota de culpa; no boletim de ocorrência de autoria conhecida, no requerimento, requisição e na portaria de instauração do inquérito policial; ou, ainda, no indiciamento realizado pela autoridade policial, bem como nos diversos provimentos e medidas cautelares, determinados e realizados nessa primeira fase da persecução penal. (...) Diante de tudo isso, bem como da possibilidade de o suspeito vir a ser indiciado, deve poder se defender" (O direito de defesa..., pp. 222/23).

${ }_{245}^{2}$ Ibid., p. 182. Vide, também, GOMES FILHO, Antonio Magalhães, Direito à prova..., pp. 144/45.
} 
Assim, o imputado pode requerer diligências à Autoridade Policial, bem como acompanhar o andamento do inquérito policial, com o propósito de evitar acusações ou medidas cautelares infundadas.

Como aclarado por José Barcelos de Souza, não há “incompatibilidade entre a regra da investigação inquisitiva com a máxima da amplitude da defesa, esta alcançando também o inquérito, embora aí não haja ainda acusação de que se defender. É que tem o indiciado interesse em evitar uma acusação equivocada e, sobretudo, um decreto de prisão, que pode fundamentar-se em peças do inquérito”. ${ }^{246}$

Entretanto, essa intervenção restrita do imputado no inquérito policial não se equivale ao contraditório. Na fase investigatória, o imputado tem direito à informação e de intervir em atos que limitem seus direitos fundamentais. Contudo, não lhe é assegurada a possibilidade de participação e de reação, com a capacidade de influenciar o julgador - o que desfigura por completo o contraditório. ${ }^{247}$

Em realidade, por conta da própria finalidade do inquérito policial, é inviável a existência do contraditório nessa fase. É que o sucesso de alguns atos de investigação depende do sigilo e da surpresa na sua realização, o que é incompatível com o citado princípio constitucional.

Por conseguinte, os dados obtidos na persecução prévia devem prestar apenas para embasar as decisões interlocutórias exaradas nessa fase e o juízo sobre a viabilidade da acusação. Tais elementos não podem influenciar o julgamento do caso pela Autoridade Judiciária, razão pela qual, repise-se, o inquérito policial deve ser excluído dos autos do processo criminal.

Excepcionalmente, podem existir momentos jurisdicionalizados durante o inquérito policial, nos quais o contraditório deve ser garantido ao imputado. É o caso da

\footnotetext{
${ }^{246}$ Teoria e prática..., p. 32.

${ }^{247}$ Tal idéia é bem resumida por Fauzi Hassan Choukr, litteris: “O acompanhamento das diligências e a faculdade de requerimento junto ao titular da investigação certamente são sinais de preocupação com a dignidade do suspeito e o colocam como sujeito da investigação, e não seu objeto. Esta postura claramente se filia à matriz acusatória do processo penal e vai ao encontro das modernas tendências reformistas em curso na Europa e América Latina. No entanto, a garantia ainda não aparece caracterizada. Mesmo conjugando-se as duas normas, o contraditório, quer pleno, parcial ou 'mitigado', para empregar alguns adjetivos encontrados na doutrina, ainda não está lá. Porque, para sua caracterização, é necessário que o suspeito tenha ciência dos atos de investigação e possa exercitar sua participação” (Garantias Constitucionais..., p. 130).
} 
produção antecipada de provas, que ocorre somente se estas forem irrepetíveis ou se houver perigo real e concreto de seu perecimento.

Tal posição parece ser a mais acertada. De fato, não se vislumbra contraditório no inquérito policial, por ser próprio de uma relação jurídico-processual, com a dialética que lhe é característica. Em contrapartida, é inegável que deve ser reservado ao imputado, em grau adequado, o direito de se defender da imputação que lhe foi feita nesta fase, para evitar a aplicação de medidas cautelares descabidas ou o advento de ação penal infundada.

\section{IV.3. O direito à prova e à investigação do crime}

O vocábulo "prova” pode ser entendido como o conjunto de atividades tendentes a formar o convencimento do Juiz sobre a alegação de um fato, ou, ainda, como o próprio resultado da atividade probatória. ${ }^{248}$

Costuma-se fazer distinção entre fonte de prova, meio de prova e objeto de prova. $^{249}$ A fonte de prova corresponde a todos os elementos materiais que se prestam ao esclarecimento de um fato, como, por exemplo, um documento ou uma pessoa. Sua existência, portanto, é anterior e autônoma ao processo. Já o meio de prova somente existe no processo, sendo o instrumento destinado a levar a fonte de prova ao Juízo. É o caso das declarações de uma testemunha; da juntada de um documento ou de um exame pericial. Objeto de prova é o fato a ser provado, que se infere da fonte e se introduz no processo pelo meio de prova. ${ }^{250}$

\footnotetext{
${ }^{248}$ Sobre as diferentes acepções do vocábulo prova, conferir BADARÓ, Gustavo Henrique Righi Ivahy, Ônus da prova..., pp. 158/59.

${ }^{249}$ Nesse sentido, conferir GRINOVER, Ada Pellegrini, et alli, As nulidades..., pp. 141/42; BADARÓ, Gustavo Henrique Righi Ivahy, Ônus da prova..., pp. 162/67; e DEZEM, Guilherme Madeira, Da prova penal..., pp. 82/89.

${ }^{250}$ Esta é a definição propugnada pela maior parte da doutrina. Contudo, Guilherme Madeira Dezem, referindo-se ao magistério de Antonio Magalhães Gomes Filho, afirma que objeto de prova não são os fatos, mas as afirmações sobre os fatos, porque é "impossível a prova de um fato, na medida em que é impossível a reconstrução integral do que efetivamente ocorreu” (Da prova penal..., pp. 85/86). Também Gustavo Henrique Righi Ivahy Badaró esclarece que o objeto da prova é sempre a "alegação de um fato" e não o "fato em si mesmo". Isso porque os fatos são acontecimentos que existem no mundo real e não comportam valorações. Apenas os conceitos sobre determinadas fatos é que podem ser considerados falsos ou verdadeiros. Por conta disso, o objeto da prova recai sobre "as alegações dos fatos feitas pelas partes como fundamentos da acusação e da defesa” (Ônus da prova..., pp. 159/60).
} 
Mencionam-se, ainda, elemento de prova e meio de busca ou de obtenção de prova. O primeiro corresponde aos "dados objetivos que confirmam ou negam uma asserção a respeito de um fato que interessa à decisão da causa”. ${ }^{251} \mathrm{O}$ segundo é definido como medida direcionada à coleta de provas (v.g., busca e apreensão, interceptação telefônica, quebras de sigilo bancário e fiscal, inspeções judiciais etc.). ${ }^{252}$

Dentro da estrutura processual, a prova passa por quatro momentos distintos: proposição, admissão, produção e apreciação. Primeiro, há a indicação ou o requerimento da prova. Em seguida, ocorre a análise judicial da sua admissibilidade, que, se resultar em juízo positivo, leva à introdução da prova no processo. Por fim, há a valoração da prova pelo Juiz. $^{253}$

Dos princípios do contraditório e da ampla defesa deriva o direito à prova, que pode ser assim conceituado: a possibilidade de as partes demonstrarem a veracidade de suas alegações, a fim de formar o convencimento judicial, por meio da coleta dos dados que entenderem pertinentes e relevantes, bem como da participação nos atos probatórios e manifestação sobre o seu resultado.

Sobre o conteúdo do direito à prova, explica Antonio Magalhães Gomes Filho que "o reconhecimento de um verdadeiro direito subjetivo à prova, cujos titulares são as partes no processo (penal, no nosso caso), supõe considerar que as mesmas devem estar em condições de influir ativamente em todas as operações desenvolvidas para a constituição do material probatório que irá servir de base à decisão; nessa visão, a prova, antes de tudo, deve ser atividade aberta à iniciativa, participação e controle dos interessados no provimento jurisdicional”. 254

Deduz-se desse conceito que o direito à prova é um dos aspectos dos direitos de ação e defesa, sendo atribuído às partes de forma equânime. Tal direito subdivide-se nos direitos de pedir, produzir e ter a prova valorada judicialmente, que são correlatos aos diferentes momentos probatórios, acima mencionados. Assim, fala-se em direito de pedir prova para se referir ao instante de sua proposição. Já o direito de produzir prova diz

${ }^{251}$ GOMES FILHO, Antonio Magalhães. "Notas sobre a terminologia da prova (reflexos no processo penal brasileiro)" in Estudos em homenagem à Professora Ada Pellegrini Grinover. YARSHEL, Flávio Luiz e MORAES, Maurício Zanoide de (orgs.). São Paulo: DPJ, 2005, p. 307.

${ }^{252}$ ZILLI, Marcos Alexandre Coelho, A iniciativa instrutória..., p. 183.

${ }^{253}$ GRINOVER, Ada Pellegrini, et alli, As nulidades..., pp. 142/43.

${ }^{254}$ Direito à prova..., p. 85. 
respeito à sua admissão pelo Juiz e introdução nos autos do processo (produção da prova propriamente dita). Por fim, o direito à valoração da prova corresponde à fase de apreciação judicial da prova, que se exprime por meio da motivação da decisão. ${ }^{255}$

Todavia, não é qualquer prova que pode ser incorporada aos autos e apreciada pela Autoridade Judiciária. Como apontado por Rogério Lauria Tucci, ${ }^{256}$ admitem-se apenas as provas pertinentes e relevantes para a elucidação dos fatos apurados; desde que os meios de obtenção e produção sejam idôneos.

A Convenção Americana sobre Direitos Humanos, em seu artigo 8, 2, “f”, cuida de uma das manifestações do direito à prova, qual seja, "o direito da defesa de inquirir as testemunhas presentes no Tribunal e de obter o comparecimento, como testemunhas ou peritos, de outras pessoas que possam lançar luz sobre os fatos”. Com a incorporação deste estatuto internacional pelo ordenamento jurídico interno, houve a consagração expressa do direito à prova no Brasil. ${ }^{257}$

No âmbito infraconstitucional, o Código de Processo Penal sofreu sensível alteração com a Lei n. ${ }^{\circ}$ 11.690/08, que modificou consideravelmente o rito do procedimento comum. No tocante ao ônus da prova, o novo texto do artigo 156 do Código de Processo Penal dispõe que “a prova da alegação incumbirá a quem a fizer, sendo, porém, facultado ao juiz de ofício: I - ordenar, mesmo antes de iniciada a ação penal, a produção antecipada de provas consideradas urgentes e relevantes, observando a necessidade, adequação e proporcionalidade da medida; II - determinar, no curso da instrução, ou antes de proferir sentença, a realização de diligências para dirimir dúvida sobre ponto relevante.”

Existem outros dispositivos, na Lei Adjetiva Penal, que conferem às partes iniciativa probatória, como, por exemplo, os artigos 41, 396-A e 400, que permitem a indicação de testemunhas; e o artigo 402, que possibilita o requerimento de diligências cuja necessidade se origine de circunstâncias ou fatos apurados na instrução.

\footnotetext{
255 Sobre os desdobramentos do direito à prova, conferir GOMES FILHO, Antonio Magalhães, Direito à prova..., pp. 88/89.

${ }^{256}$ Direitos e garantias..., pp. 229/30.

${ }^{257}$ GOMES FILHO, Antonio Magalhães, Direito à prova..., p. 82.
} 
Sendo assim, no processo penal, cabe às partes, em regra, a iniciativa probatória, podendo o Juiz atuar subsidiariamente para esclarecer dúvidas sobre questões relevantes suscitadas pelas partes. Nessa hipótese, a Autoridade Judiciária deve atentar para os princípios da presunção de inocência e do in dubio pro reo, sendo-lhe vedado suprir a atuação do órgão acusatório. ${ }^{258}$

É inadmissível, contudo, a atividade investigatória do Juiz, pois depende da busca de fontes de prova - o que lhe é vedado por afetar a sua imparcialidade, conforme demonstrado no tópico sobre a participação do Magistrado no inquérito policial (item III.6.3).

Pode-se avistar mais distante e, a partir do direito à prova, inferir também o direito das partes à investigação. Nessa linha, ressalta Antonio Magalhães Gomes Filho que “o direito à prova também deve ser reconhecido antes ou fora do processo, até como meio de se obter elementos que autorizem a persecução, ou possam evitá-la. Partindo dessa constatação, parece possível identificar, num primeiro momento, um direito à investigação, pois a faculdade de procurar e descobrir provas é condição indispensável para que se possa exercer o direito à prova; na tradição inquisitória, as atividades de pesquisa probatória prévia constituem tarefa confiada exclusivamente aos órgãos oficiais da investigação penal (Polícia Judiciária e Ministério Público), mas, no modelo acusatório, com a consagração do direito à prova, não ocorre ser possível negá-las ao acusado e ao defensor, com vistas à obtenção do material destinado à demonstração das teses defensivas”. ${ }^{259}$

No tocante ao imputado, o direito à investigação veio expresso no artigo 14 do Código de Processo Penal, que lhe permite requisitar diligências à Autoridade Policial. ${ }^{260}$

\footnotetext{
${ }^{258}$ Leciona Denise Neves Abade que “a iniciativa probatória do juiz, para esclarecer suas dúvidas quanto ao convencimento dos fatos, somente poderá ocorrer para a matéria que deve ser provada pela defesa notadamente, as excludentes de antijuridicidade, da culpabilidade e da punibilidade - pois, havendo dúvida, deve o magistrado decidir pela absolvição” (Garantias..., p. 154).

${ }^{259}$ Direito à prova..., pp. 86/87.

260 Segundo André Boiani e Azevedo e Édson Luís Baldan, “mister que a autoridade policial, como presidente da fase investigatória administrativa reservada à ação da polícia judiciária, preserve, no âmbito de suas atribuições, a garantia do devido processo legal, potencializando o uso da disposição garantista encerrada no artigo 14 do Código de Processo Penal, propiciando que nos autos do inquérito policial ingressem, também, os elementos de prova (dês que legítimos) de interesse da defesa da pessoa sujeita à investigação ou indiciamento” (“A preservação do devido processo legal pela investigação defensiva (ou do direito de defender-se provando”..., p. 06).
} 
Tal faculdade é exemplo de manifestação endógena do direito de defesa no inquérito policial, pois é exercida nos próprios autos do investigatório. ${ }^{261}$

Com esteio no referido dispositivo legal, entende-se que o imputado "tem direito a exigir que a autoridade o interrogue, forme o corpo de delito, realize quaisquer perícias necessárias ao esclarecimento da verdade, ouça o ofendido, inquira testemunhas por ele apontadas, desde que indispensáveis ou úteis à elucidação das circunstâncias do fato, junte documentos nos autos etc.”. 262

Discutiu-se na doutrina a possibilidade de a Autoridade Policial indeferir diligência solicitada pelo imputado, uma vez que o texto legal subordinou a sua realização ao “juízo da autoridade”. Contudo, este debate restou superado com a promulgação da Constituição da República de 1988, que garantiu o direito de defesa do imputado inclusive na fase preliminar.

Logo, a Autoridade Policial deve executar as providências requeridas pelo imputado, desde que demonstrada a sua pertinência e relevância para a elucidação dos fatos investigados. ${ }^{263} \mathrm{Em}$ outras palavras, "não pode a autoridade policial negar o requerimento de diligência formulada pelo acusado, desde que guarde importância e correlação com o esclarecimento dos fatos e a defesa do acusado". ${ }^{264}$ Admite-se o indeferimento apenas de medidas inúteis, protelatórias ou desnecessárias, o que deve ser feito motivadamente. ${ }^{265}$

Importante lembrar que a faculdade prevista no artigo 14, do Código de Processo Penal, não se equipara à investigação defensiva. Esta também é forma de

\footnotetext{
${ }^{261}$ Marta Saad diferencia o exercício exógeno e endógeno do direito de defesa no inquérito policial. O primeiro é aquele efetivado fora dos autos do inquérito policial, por meio de algum remédio constitucional (habeas corpus ou mandado de segurança) ou por requerimentos endereçados ao Juiz ou ao Promotor de Justiça. Por sua vez, o exercício do direito de defesa é endógeno, quando praticado nos autos do inquérito policial, por meio da oitiva do imputado ou de diligências que porventura ele solicite à Autoridade Policial (SAAD, Marta, $O$ direito de defesa..., pp. 269/72).

${ }^{262}$ ALMEIDA, Joaquim Canuto Mendes de, Princípios..., pp. 213/14.

${ }^{263}$ Como enfatizado por Antonio Scarance Fernandes, o Delegado de Polícia não deve impedir a execução de diligências importantes requeridas pelo imputado, "principalmente porque, no sistema brasileiro, não há, como na legislação italiana, direito de o próprio indiciado realizar investigações para introduzi-las nos autos” (Reação Defensiva..., p. 132).

${ }^{264}$ SAAD, Marta, $O$ direito de defesa..., p. 351.

265 O Projeto de Lei n. ${ }^{\circ}$ 4.209/01, referente à investigação criminal, acrescenta parágrafo único ao artigo 14 do Código de Processo Penal, prevendo a possibilidade de se recorrer à Autoridade Policial superior, ou representar ao Ministério Público, caso o pedido de diligência seja indeferido.
} 
materialização dos direitos à prova e à investigação, mas desvinculada da investigação pública e que permite atuação muito mais ampla do imputado.

De fato, enquanto o inquérito policial é caracterizado por limitada participação do imputado, com o objetivo de tutelar seus interesses mais relevantes, principalmente seus direitos fundamentais; ${ }^{266}$ a investigação defensiva é dirigida pelo defensor, que define a sua própria linha investigatória, com o propósito de reunir, licitamente, dados materiais favoráveis ao imputado e capazes de influir no convencimento judicial.

\section{IV.4. A necessidade de investigação criminal defensiva em um sistema processual penal de partes}

Deduz-se, do acima exposto, que um modelo processual penal acusatório deve se nortear pelos direitos fundamentais de igualdade e de defesa, os quais incidem em todo o rito persecutório, mesmo na fase preliminar. A investigação defensiva decorre de tais direitos e, mais do que disso, serve para garantir a sua efetiva aplicação. ${ }^{267}$

De saída, importa observar que direito e garantia são institutos distintos. Enquanto os direitos possuem índole declaratória, pois reconhecem a existência de um bem ou vantagem a seu titular; as garantias têm natureza assecuratória, uma vez que se destinam a fazer valer os direitos. ${ }^{268}$

\footnotetext{
${ }^{266}$ ALMEIDA, Joaquim Canuto Mendes de, Princípios..., p. 117; e SCARANCE FERNANDES, Antonio, Processo..., pp. 64/65.

${ }^{267}$ Carlo Taormina aponta a necessidade de investigação defensiva em um processo penal acusatório, verbis: "Le attività di investigazione difensive, con le caratteristiche generali fin qui messi in luce, evidenziano un taglio di assoluta novità nel ruolo del difensore, impensabile in una ottica da processo inquisitorio ed invece indispensabile per uno ispirato modello accusatorio. È ben vero che quest'ultimo sistema dovrebbe comportare una più incisiva anzi assordente conformazione della difesa, non meno dell'accusa, alla qualità di parte, come tale perciò sensibile al proprio interesse piuttosto che all'oggettività dell'accertamento penale. Tutto cio è incontestabile e va coltivato con determinazione giacché solo dalla contrapposizione tra accusa e difesa possono scaturire il confronto e la decisione più aderente allá realtà” (Il regime della prova nel Processo Penale. Torino: G. Giappichelli Editore, 2007, p. 160).

${ }^{268}$ MOURA, Maria Thereza Rocha de Assis e PITOMBO, Cleunice A. Valentim Bastos. "Defesa Penal: Direito ou Garantia”..., p. 111. Esclarece Denise Neves Abade que “enquanto os direitos representam por si só certos bens, as garantias são acessórias e, muitas delas, adjetivas (ainda que possam ser objeto de um regime constitucional substantivo); os direitos permitem a realização das pessoas e inserem-se direta e imediatamente, por isso, nas respectivas esferas jurídicas, as garantias só nelas se projetam pelo nexo que possuem com os direitos” (Garantias..., p. 102).
} 
José Afonso da Silva, citando Ruy Barbosa, esclarece que “uma coisa são os direitos, outra as garantias, pois devemos separar, 'no texto da lei fundamental, as disposições meramente declaratórias, que são as que imprimem existência legal aos direitos reconhecidos, e as disposições assecuratórias, que são as que, em defesa dos direitos, limitam o poder. Aquelas instituem os direitos; estas, as garantias: ocorrendo não raro juntar-se, na mesma disposição constitucional, ou legal, a fixação da garantia, com a declaração do direito'”, 269

Nessa ótica, é possível vislumbrar a investigação defensiva como garantia fundamental do imputado, inerente a um processo de partes, na medida em que constitui instrumento para a concretização dos direitos constitucionais de igualdade e de defesa. ${ }^{270}$

De fato, consoante o princípio da isonomia, as partes devem ter paridade de armas, ou seja, os mesmos direitos, ônus e deveres, em cada grau e estado do procedimento. Assim, se, de um lado, existe a investigação pública cujo objetivo precípuo é reunir material probatório para amparar a opinio delicti do Ministério Público ou da acusação privada; de outro, deve-se permitir que o imputado, por meio de seu defensor, efetue atividade investigatória para suportar as suas teses de defesa.

A necessidade de investigação defensiva para garantir a isonomia entre as partes, na persecução penal, é ainda maior nos casos em que a investigação pública está a cargo do Ministério Público, o qual, como se viu, é sujeito parcial e dirige a investigação no sentido acusatório, sem se preocupar com os interesses do imputado.

${ }^{269}$ Curso de Direito Constitucional..., p. 183. A respeito das garantias constitucionais, afirma José Afonso da Silva que "essas garantias não são um fim em si mesmas, mas instrumentos para a tutela de um direito principal. Estão a serviço dos direitos humanos fundamentais, que, ao contrário, são um fim em si, na medida em que constituem um conjunto de faculdade e prerrogativas que asseguram vantagens e benefícios diretos e imediatos a seu titular" (Ibid., p. 186).

${ }^{270} \mathrm{Na}$ Itália, a reforma processual de 1988 reconheceu que a investigação defensiva é intrínseca a um processo de partes e decorre do direito de defesa e do princípio da paridade de armas entre acusação e defesa. Como explanado pela doutrina italiana: “Appartiene alla natura intrinseca del processo di parti garantire il diritto di difendersi provando (Frigo) e più in generale quale imprescindibile corollario del principio di parità tra accusa e difesa assicurato in ogni stato e grado del procedimento dalla legge delega per l'emanazione del nuovo codice di procedural penale” (SIRACUSANO, Delfino; TRANCHINA, Giovanni e ZAPPALÀ, Enzo. Elementi di diritto processuale penale. $3^{\mathrm{a}}$ ed.. Milano: Giuffrè, 2007, p. 175). No mesmo sentido: "Il (correto) funzionamento del sistema accusatorio però implica necessariamente la ricerca delle prove da parte di entrambe le parti, sai quella pubblica che quella privata. Cio perché solo le parti sono in grado di valutare correttamente quali sono gli elementi idonei a convincere il giudice. Il corollario di tale impostazione è il riconoscimento del diritto di indagare anche al privato" (STEFANI, Eraldo. Codice dell'indagine difensiva penale - commentato ed annotato con la giurisprudenza e la deontologia. Milano: Giuffrè, 2005, p. 151). Vide, ainda, TONINI, Paolo. Manuale di Procedura Penale. 8a ed.. Milano: Giuffrè, 2007, p. 493. 
Já o direito de defesa, que se desdobra nos direito à prova e à investigação, preceitua a possibilidade de reagir aos atos da parte contrária com os meios de prova admitidos em Direito. Especificamente no tocante ao direito à prova, esclarece Rogério Lauria Tucci que se expressa "na concessão aos sujeitos parciais (no processo penal, da persecutio criminis), de idênticas possibilidades de oferecer e materializar, nos autos, todos os elementos de convicção demonstrativos da veracidade dos fatos alegados, bem como de participar de todos os atos probatórios e manifestar-se sobre os seus respectivos conteúdos”. ${ }^{271}$

Ora, de nada adiantaria garantir ao imputado direito à prova, em sede judicial, sem lhe dar oportunidade de buscar previamente as fontes de prova, o que ocorre por meio da atividade investigatória.

Ademais, por meio da investigação defensiva, faculta-se ao imputado exercer ativamente o seu direito de defesa, desde a fase preliminar, recolhendo os dados indispensáveis à comprovação de seus argumentos e que podem evitar o advento de ação penal.

Diante disso, um verdadeiro e justo processo penal acusatório deve assegurar que acusação e defesa tenham oportunidades equânimes para sustentar as suas teses, inclusive durante a instrução preliminar. Até porque, nesta fase, já existe imputação em sentido amplo e, por conseguinte, o inegável interesse do imputado em demonstrar a sua inocência.

Logo, se um ordenamento jurídico prevê procedimento investigatório público, de cunho nitidamente acusatório, é imprescindível que admita também a investigação autônoma do crime pela defesa.

${ }^{271}$ TUCCI, Rogério Lauria, Direitos e garantias..., p. 227 


\section{A INVESTIGAÇÃO CRIMINAL DEFENSIVA NO DIREITO ESTRANGEIRO}

\section{V.1. Preliminarmente: a experiência norte-americana}

Os Estados Unidos da América herdaram da colonização inglesa o sistema jurídico da common law, constituído, basicamente, por um conjunto de princípios e regras jurídicas não escritas, cuja autoridade provém dos usos e costumes e da jurisprudência. Na common law, cabe ao Judiciário a elaboração do Direito e sua gradativa evolução, ao passo que na civil law (sistema romano-germânico) a fonte mais importante do Direito é a lei. ${ }^{272}$

Por ser um modelo jurídico com características muito peculiares, não é possível fazer transposição adequada dos seus institutos para o ordenamento jurídico brasileiro, de tradição romano-germânica. Diante disso, ao invés de se realizar exame minucioso do Direito norte-americano, optou-se por traçar uma noção geral do seu funcionamento e mencionar os pontos mais interessantes ao estudo da investigação defensiva.

\section{V.1.1. A organização judiciária norte-americana}

O Poder Judiciário norte-americano divide-se nos âmbitos federal e estadual, sendo que os Estados-membros desfrutam de total liberdade para estruturar os seus

\footnotetext{
272 João Gualberto Garcez Ramos distingue a common law da civil law nos seguintes termos: "A diferença entre os sistemas de direito comum e o de direito continental é essencialmente metodológica. No primeiro caso, utiliza-se o método indutivo; no segundo, o método dedutivo.

(...)

Nos dois casos, a jurisdição tem a mesma função: resolver casos concretos.

Nos países de tradição jurídica inglesa, a jurisdição resolve casos concretos baseada em doutrinas criadas para solucionar litígios anteriores. Quando não há hipótese anterior, constrói uma doutrina nova para ser aplicada ao problema em exame; não uma doutrina inteiramente nova, mas o resultado da agregação dos argumentos utilizados para julgar aspectos semelhantes de casos anteriores. Daí porque seu sistema jurídico é também conhecido como ‘direito de casos’ (case law).

Nos países de tradição jurídica continental, a jurisdição resolve casos concretos baseada na lei” (Curso de Processo Penal norte-americano. São Paulo: Revista dos Tribunais, 2006, pp. 50/51). Ainda sobre o conceito de Common Law, ver: SOARES, Guido Fernando Silva. "Estudos de Direito Comparado: o que é a 'Common Law', em particular, a dos EUA” in Revista da Faculdade de Direito da Universidade de São Paulo, v. 92, 1997, pp. 163/98.
} 
sistemas judiciários, conforme as suas respectivas Constituições. ${ }^{273}$ A maioria dos Estados segue, em linhas gerais, o modelo federal. ${ }^{274}$

O sistema judiciário federal é encabeçado pela Suprema Corte, criada pela Constituição de 1787 e regulamentada pelo Judiciary Act de 24 de setembro de 1789. Atualmente, a Suprema Corte é composta por um Juiz-presidente e oito Juízes associados, que devem ser indicados pelo Presidente da República e submetidos à avaliação do Senado. Se aprovados por este órgão, há a nomeação vitalícia dos Juízes pelo Presidente da República.

Após a entrada em vigor da $14^{\mathrm{a}}$ emenda à Constituição, em 1868, a Carta de Direitos (Bill of Rights) tornou-se cogente para os Estados-membros. Com isso, a Suprema Corte passou a ter poder de supervisão sobre as decisões judiciais emanadas por qualquer tribunal do país, federal ou estadual, para verificar a sua conformidade à Carta de Direitos. Tal poder de fiscalização materializa-se por meio dos “mandados de certificação” (writs of certiorari), que representam a faculdade da Suprema Corte - e não direito das partes - de analisar certas matérias. "Por meio dos atuais ‘mandados de certificação’, a Suprema Corte requisita dos demais tribunais informações a respeito de um determinado caso por eles julgado; revê os argumentos utilizados na decisão; colhe, se achar necessário, novos argumentos orais; discute os fundamentos e emite uma decisão sobre a correta interpretação da Constituição nesses casos”. 275

Outrossim, a Constituição atribuiu ao Congresso Nacional a competência para instituir tribunais inferiores à Suprema Corte, para julgar questões federais (federal question cases). ${ }^{276}$ Os primeiros tribunais dessa natureza foram criados pelo Judiciary Act de 1789, que repartiu os Estados Unidos em treze distritos judiciais, arranjados em três circuitos - posteriormente o número de circuitos aumentou para treze. Tal estatuto criou as

\footnotetext{
${ }^{273}$ Para acurado exame do sistema judiciário norte-americano, vide: DAVID, René. Os grandes sistemas do Direito contemporâneo. Tradução de Hermínio A. Carvalho. São Paulo: Martins Fontes, 1998, pp. 357 e segs.; e RAMOS, João Gualberto Garcez, Curso de Processo Penal..., pp. 86/107.

${ }^{274}$ René David chama a atenção para o fato de que a divisão entre Direito Federal e Direito dos EstadosMembros é própria dos Estados Unidos da América e nunca existiu na Inglaterra. O autor, em sua obra, enuncia as principais semelhanças e diferenças entre o Direito norte-americano e Direito inglês (DAVID, René, Os grandes sistemas..., pp. 367/80).

${ }^{275}$ RAMOS, João Gualberto Garcez, Curso de Processo Penal..., p. 90.

${ }^{276}$ A regra geral é a competência da jurisdição estadual. A jurisdição federal ocorre apenas nos casos expressos em lei ou no texto constitucional, que normalmente se relacionam a dois tipos de matérias: aquelas que dizem respeito à violação da Constituição ou de lei federal; ou aquelas referentes aos interesses de
} 
“Cortes Federais de Circuito" (US circuit courts) e as “Cortes Federais de Distrito” (US district courts), que são os órgãos jurisdicionais federais de primeira instância, cujas decisões podem ser revistas pelas “Cortes Federais de Apelação de Circuito” (US circuit courts of appeal). Os Juízes desses tribunais também são indicados e nomeados vitaliciamente pelo Presidente da República, mediante prévia aprovação do Senado.

Por outro lado, os Estados-membros, como destacado, possuem autonomia para formar os seus sistemas judiciários, sendo que a maior parte baseia-se no modelo federal. Assim, existem as "Supremas Cortes estaduais" (state supreme courts), que apreciam os casos considerados relevantes para o Direito estadual; as “Cortes de Julgamento" (trial courts), que realizam julgamento por júri (jury trial) ou de forma monocrática (bench trial); e as "Cortes de Apelação" (appellate courts), que examinam os recursos interpostos contras as decisões proferidas pelas trial courts. A investidura dos Magistrados é temporária e pode se dar por indicação do Governador, com posterior confirmação pelo Senado estadual, ou por eleição.

\section{V.1.2. A investigação criminal norte-americana}

Observe-se, antes de mais nada, que o modelo norte-americano é tipicamente “adversarial”, ou seja, a gestão da prova é incumbência das partes e não do Juiz. As partes são responsáveis pela marcha processual e detêm "tanto o poder de investigar os fatos, como o de instruir o feito, inquirindo testemunhas, consultando peritos e até mesmo determinando o que será objeto de indagação”. ${ }^{277}$ A Autoridade Judiciária, para não comprometer a sua imparcialidade, deve-se manter inerte com relação à atividade probatória.

A persecução penal, nos Estados Unidos da América, é ordenada em três grandes fases: investigatória, adjudicatória e judicial (denominadas, respectivamente, investigatory stage, adjudicatory stage e judicial stage). ${ }^{278}$

determinadas pessoas (a própria União, diplomatas estrangeiros e cidadãos pertencentes a Estados diferentes) (DAVID, René, Os grandes sistemas..., pp. 384/85).

${ }^{277}$ ZILLI, Marcos Alexandre Coelho, A iniciativa instrutória..., p. 44.

${ }^{278}$ Conferir RAMOS, João Gualberto Garcez, Curso de Processo Penal..., pp. 177/95. 
A investigação não possui rito formal previamente estabelecido, desenvolvendo-se a partir das especificidades de cada caso. Divide-se em duas fases: na primeira, reúnem-se os dados necessários à determinação dos fatos e identificação de um suspeito; na segunda, após a individualização do suspeito, assume a forma de persecução penal propriamente dita. ${ }^{279}$

Na fase inicial da investigação, por inexistir suspeito oficial, não se fala em direito de defesa e não há prazo para o encerramento das diligências, nem mesmo prescricional. Tal etapa caracteriza-se, ainda, pelo completo sigilo dos atos.

A partir do instante em que se identifica o suspeito, o que normalmente ocorre com a prisão ou alguma outra medida cautelar, começa efetivamente a persecução criminal. Neste momento, nasce uma série de garantias para o suspeito, como o direito de defesa (com destaque para o aspecto de não se auto-incriminar), o direito à integridade e à intimidade; a jurisdicionalização de medidas restritivas de direitos fundamentais (busca domiciliar e quebra de sigilo das comunicações e de dados); dentre outras.

A investigação é comumente realizada pelos órgãos policiais, por ser inerente às suas funções. ${ }^{280}$ Todavia, tal atividade não é privativa da Polícia Judiciária, tanto que, “nos últimos anos, os promotores passaram também a investigar, embora em muito menos hipóteses do que os agentes policiais. Também é possível afirmar que esse fenômeno é mais freqüente entre os promotores federais do que entre os estaduais; e que se concentra

\footnotetext{
279 "Num primeiro período das investigações, os agentes policiais investigam os fatos, colhem as provas e procuram estabelecer uma causa provável (probable cause), indispensável para a emissão de mandados, seja de busca, seja de apreensão ou de prisão.

Nesse primeiro período, em que o foco das investigações é um fato - e não um autor de um fato -, as investigações se desenvolvem secretamente.

(...)

Se a autoridade investigante identificar um suspeito e se contra ele pesarem evidências que tornem a causa provável, a autoridade policial pode iniciar a persecução penal. Par excellence, o ato que sempre traduziu o início da persecução - até porque é inegável sua gravosidade em relação a alguém - é a prisão (arrest) do imputado, embora a própria Suprema Corte, em decisões recentes, tenha mostrado alguma dúvida a respeito. Contudo, é possível afirmar que é com a prisão de um suspeito que a investigação a ele se direciona e se torna, para todos os fins, uma persecução penal.

Com isso, passam a ser aplicáveis novas e importantes cláusulas da Carta de Direitos” (Ibid., pp. 180/81).

${ }^{280}$ A Polícia Judiciária, nos Estados Unidos, é marcada por enorme fragmentariedade, existindo inúmeras agências de investigação criminal em cada uma das esferas políticas. Cada uma dessas agências é subordinada ao respectivo chefe do Poder Executivo, sem qualquer vínculo hierárquico com o Ministério Público.
} 
em algumas espécies de crimes, como os econômicos, os de tráfico de entorpecentes etc.". 281

Destaca Bruno Calabrich que o modelo norte-americano é o exemplo mais contundente de domínio do Ministério Público sobre a persecução prévia. "Embora seja necessária uma autorização judicial (warrant) para medidas cautelares de prisão, de busca (search) e de apreensão (seize ou seizure), nos Estados Unidos o Ministério Público é o verdadeiro senhor da investigação criminal, não havendo um controle judicial valorativo no correr da fase investigativa nem no caso de seu arquivamento. Seu poder discricionário (discretion) permite decidir sobre a submissão do caso à preliminary hearing e ao grand jury, para a confirmação da existência de uma probable cause, e mesmo negociar com o investigado a troca de uma admissão de culpa por uma pena mais reduzida ou por uma desqualificação do delito para tipos com sanções menos severas (plea bargaining)”. ${ }^{282}$

Também a defesa possui poderes investigatórios, podendo colher os meios de prova necessários para fundamentar suas alegações, devendo observar os mesmos requisitos processuais das provas obtidas em Juízo. ${ }^{283}$ Lembra João Gualberto Garcez Ramos $^{284}$ que, em razão da onerosidade da Justiça criminal norte-americana, as partes preferem produzir as provas fora do Juízo e, posteriormente, introduzi-las nos autos, na forma documental, para a discussão durante o julgamento.

Por isso, é comum as Promotorias e os grandes escritórios de advocacia possuírem notários para auxiliá-los na produção de depoimentos pré-processuais, sendo que essas inquirições podem ser acompanhadas pelos advogados da parte contrária e pelos Promotores. $^{285}$

Na etapa adjudicatória, consistente em preparação para a judicialização da causa, o Promotor deduz a acusação ${ }^{286}$ e o Juiz decide sobre a admissibilidade e licitude

\footnotetext{
${ }^{281}$ RAMOS, João Gualberto Garcez, Curso de Processo Penal..., p. 179.

${ }^{282}$ Investigação..., pp. 79/80.

283 Não se olvide que, no processo penal norte-americano, vigora o princípio da liberdade das provas, ou seja, o uso de determinado meio de prova em Juízo não depende de expressa previsão legal. Basta que a prova seja produzida e considerada apta a convencer o julgador.

${ }^{284}$ Curso de Processo Penal..., p. 190.

285 Ibid., pp. 190/91.

${ }^{286}$ A acusação é exercida em juízo exclusivamente pelo Ministério Público, uma vez que o Direito norteamericano não prevê qualquer hipótese de ação penal de iniciativa privada. Tal órgão divide-se em três níveis: federal (US Attorney General e US Attorneys), estadual (Attorneys General of the State e Assistants Attorney General) e dos condados (District Attorneys). Enquanto o US Attorney General é nomeado pelo
} 
das provas apresentadas pelas partes. É constituída, essencialmente, pelas audiências de fiança (bail hearings), pelas audiências anteriores ao julgamento (pretrial hearings) e pela formalização da acusação.

Na fase judicial, há a instrução da causa, alegações das partes técnicas (Promotor, assistente de acusação e defensor) e julgamento pelo Juiz (bench veredict) ou pelo pequeno Júri (petty jury veredict), que apenas proferem veredicto de culpado (guilty) ou inocente (not guilty). Se houver condenação, passa-se à etapa de sentenciamento (sentencing proceedings), em que o Juiz deve verificar a pena merecida pelo réu e proferir a sentença. $^{287}$

Conclui-se, portanto, que a investigação defensiva é plenamente admissível nos Estados Unidos da América, até mesmo por ser conseqüência natural do regime jurídico adotado neste país, que atribui às partes a iniciativa investigatória e probatória. Os meios de prova obtidos na investigação defensiva podem ser utilizados na fase judicial, desde que expressamente admitidos pelo Juiz na etapa adjudicatória.

Não há procedimento rígido previsto em lei para a realização da investigação defensiva, como, aliás, é característico de sistema jurídico da common law. No entanto, devem ser obedecidas as diretrizes gerais estabelecidas no texto constitucional e as orientações emanadas dos Tribunais.

\section{V.2. Nosso paradigma: o modelo italiano}

\section{V.2.1. A investigação criminal na Itália}

A Itália sofreu, há duas décadas, grande modificação estrutural em sua legislação processual penal: de sistema misto cuja produção de prova era atribuição do Juiz Instrutor passou a sistema predominantemente acusatório.

Presidente dos EUA, com a aprovação do Senado; os Attorney General of the State e os District Attorneys normalmente são eleitos pela comunidade. São cargos, portanto, eminentemente políticos (CALABRICH, Bruno, Investigação..., p. 79). 
Até o ano de 1988, quando foi promulgado o atual Código de Processo Penal, ${ }^{288}$ a persecução penal estruturava-se em duas fases: uma de instrução, de caráter inquisitório, destinada à busca dos elementos de prova; e outra de debates, aparentemente inspirada em princípios acusatórios, voltada à decisão da causa.

A atividade investigatória e probatória concentrava-se nas mãos do Magistrado, sem a interferência direta das partes (Ministério Público e imputado). O contraditório era diferido, ou seja, as partes manifestavam-se apenas na fase de debates sobre a prova previamente produzida. Assim, os elementos probatórios contidos nos autos de instrução ingressavam na fase de debates e eram utilizados para amparar a decisão final do Juiz. ${ }^{289}$

Com a reforma processual, instituiu-se um sistema com características tipicamente acusatórias. ${ }^{290}$ Conforme explicitado por Ennio Amodio, ${ }^{291}$ os juristas responsáveis pela elaboração do novo Código de Processo Penal pautaram-se por três objetivos primordiais, com o propósito de suprimir os aspectos inquisitórios anteriormente vigentes: (i) superar toda manifestação residual do autoritarismo do Código Rocco; (ii) efetivar os princípios constitucionais que tutelam os direitos de liberdade e de defesa no

${ }^{287}$ É possível recorrer apenas do veredicto condenatório, o que dá origem a um novo processo, a ser examinado pela superior instância. Não cabe recurso contra o veredicto absolutório, devido à cláusula que proíbe colocar uma pessoa duas vezes em perigo por meio de um processo (double jeopardy clause).

${ }^{288}$ O Código de Processo Penal italiano, fortemente influenciado pelo modelo adotado na Alemanha em 1974, entrou em vigor no dia 24 de outubro de 1989, substituindo o Código de Rocco, de 1930. O novo Código foi elaborado por Comissão presidida por Gian Domenico Pisapia e composta por oito professores universitários, oito magistrados e um advogado. Em artigo publicado na Revista Brasileira de Ciências Criminais, Ennio Amodio examina o contexto em que surgiu a atual Lei Adjetiva Penal italiana e, especialmente, a influência dos acadêmicos no processo de produção normativa ("Vitórias e derrotas da cultura dos juristas na elaboração do novo Código de Processo Penal” in Revista Brasileira de Ciências Criminais, n. ${ }^{\circ} 25$, jan./mar. de 1999, pp. 09/22).

${ }^{289}$ Pasquale Ventura sintetiza as principais características do processo penal italiano durante a vigência do Código de Processo Penal de 1930 (Le indagini difensive. Milano: Giuffrè, 2005, pp. 07/08).

${ }^{290}$ A princípio, a reforma italiana pretendeu implantar um sistema acusatório puro, o que não vingou por questões diversas. A esse respeito, lembra Antonio Magalhães Gomes Filho que: "Essa radical transformação de um sistema tradicionalmente misto para um modelo acusatório puro, repetindo experiências históricas já mencionadas, não teve a esperada consistência e duração, sendo em pouco tempo superada por reformas que reintroduziram alguns dos elementos característicos do processo inquisitório. Vários fatores podem ser apontados para isso: a luta contra a criminalidade organizada, que invariavelmente consegue cooptar a opinião pública para posições contrárias à promoção das liberdades individuais; o despreparo dos operadores jurídicos para os novos papéis, especialmente num país em que juízes e membros do Ministério Público pertencem à mesma carreira; a falta de instrumentos adequados ao exercício efetivo do direito da defesa à obtenção de provas na fase de investigação; a previsão de ritos alternativos, nos quais não há o dibattimento, etc.” (Direito à prova..., p. 71). Para Luigi Ferrajoli, a reforma processual italiana não logrou estabelecer, efetivamente, um processo penal acusatório. Dentre os inúmeros motivos apontados pelo jurista, destaca-se o fato de o defensor permanecer em posição inferior em relação ao órgão acusatório, uma vez que o membro do Ministério Público integra a Magistratura e, por isso, possui vínculos mais estreitos com os Juízes (Direito e razão..., pp. 592/97).

291 “Vitórias e derrotas da cultura dos juristas na elaboração do novo Código de Processo Penal”..., p. 16. 
processo penal; (iii) construir um sistema normativo livre das contradições decorrentes de um ordenamento marcado por um "garantismo inquisitório”, isto é, uma estrutura essencialmente autoritária, incrementada superficialmente pela concessão de algumas garantias.

Certamente, a principal inovação foi a abolição da figura do Juiz instrutor e a atribuição às partes dos poderes de investigar e buscar os elementos probatórios, conforme estabelecido no artigo 111 da Constituição da República e no artigo 190 do Código de Processo Penal. $^{292}$

Como assinalado por Paolo Tonini, ${ }^{293}$ adotou-se o princípio do contraditório na formação da prova, sobre a qual o Juiz deve decidir na fase de debates. Dessarte, como regra geral, considera-se prova aquela trazida pelas partes, sob contraditório, na fase do juízo oral (denominada dibattimento).

A Autoridade Judiciária passou a ter, predominantemente, função fiscalizatória (examinando a admissibilidade das provas produzidas) e decisória (apreciando a matéria suscitada). A sua iniciativa probatória tornou-se residual, sendo admitida excepcionalmente, em casos de absoluta necessidade, conforme estipulado no artigo 507 do Código de Processo Penal.

Contudo, o referido dispositivo vem sendo interpretado de maneira ampliativa pela Corte de Cassação italiana, a fim de incrementar os poderes instrutórios do Juiz. ${ }^{294}$ Em realidade, nos últimos anos, o legislador italiano procurou atenuar o princípio dispositivo na produção de provas, preservando certa atividade probatória judicial.

Com relação à investigação criminal, foi criado um novo modelo, denominado indagini preliminari, a cargo do Ministério Público, que pode conduzi-lo diretamente ou por meio da Polícia Judiciária. O Juiz intervém tão-somente se houver a necessidade de

\footnotetext{
${ }^{292}$ A legislação italiana citada neste trabalho foi transcrita em apêndice próprio, com o objetivo de facilitar a sua leitura.

293 “Direito de defesa e prova científica: novas tendências do processo penal italiano”..., p. 198. No mesmo sentido: FERRAJOLI, Luigi, Direito e razão..., pp. 590/91.

${ }^{294}$ BADARÓ, Gustavo Henrique Righi Ivahy, Ônus da prova..., pp. 142/44.
} 
jurisdicionalização de alguma medida, mormente quando se está em jogo restrição a direitos fundamentais do imputado. Trata-se de Juiz de garantias e não mais instrutor. ${ }^{295}$

As indagini preliminari estão reguladas nos artigos 326 a 415 do Código de Processo Penal, sendo conceituadas como as investigações desenvolvidas pelo Ministério Público e a Polícia Judiciária, no âmbito de suas respectivas atribuições, com o objetivo de alcançar as determinações necessárias ao exercício da ação penal (artigo 326 do Código de Processo Penal).

Dessarte, de acordo com o texto legal, as indagini preliminari visam obter elementos relacionados à possível prática delitiva, suficientes para constatar a viabilidade, ou não, da ação penal. Os dados obtidos nas indagini preliminari servem também para amparar as medidas cautelares proferidas nesta fase. ${ }^{296}$

O artigo 327 do Código de Processo Penal confere expressamente ao Ministério Público a direção das investigações, que, para executar tal atividade, pode dispor diretamente da Polícia Judiciária.

Na Itália, o Ministério Público integra o Poder Judiciário, sendo dotado de garantias idênticas às da Magistratura. ${ }^{297}$ Não obstante, as atividades que desenvolve

295 Para Ennio Amodio, o atual modelo de investigação criminal italiano deve ser reformado, pois a práxis demonstrou que a liberdade concedida ao Ministério Público, na fase investigatória, degenerou-se em desvantagem da posição da defesa e do efetivo controle por parte do giudice per le indagini preliminari ("Il processo penale tra disregazione e recupero del sistema” in L'indice penale, Ano VI, n. ${ }^{\circ}$ 1, gennaio/aprile 2003, p. 17).

296 TONINI, Paolo, Manuale..., p. 394.

297 “O Ministério Público italiano atualmente pertence ao quadro da Magistratura, sendo chamado de magistratura requerente. Seu órgão de cúpula é o Conselho Superior da Magistratura, que tem trinta e três integrantes, entre eles o Presidente da Corte de Cassação, o Procurador-Geral, o Presidente da República e trinta membros, parte eleita pelos próprios magistrados (vinte) e parte pelo Parlamento (dez).

(...)

Os membros do Ministério Público italiano são recrutados por concurso público. É-lhes assegurada a garantia de inamovibilidade. O mecanismo de promoção não prevê competição entre os candidatos por um número limitado de vagas. A progressão na carreira se dá automaticamente pelo critério da antigüidade” (ABADE, Denise Neves, Garantias..., pp. 38/39). Ada Pellegrini Grinover chama a atenção para o fato de que essa confusão institucional entre Ministério Público e Magistratura, na Itália, pode ferir a imparcialidade do julgador. In verbis: “...na Itália a carreira da magistratura é única, congregando os verdadeiros juízes e os integrantes do Ministério Público, que podem até passar de uma função para outra, ao longo de sua vida profissional. Trata-se de um antigo vício do ordenamento italiano: e embora este tenha atuado em profundidade, com o Código de Processo Penal de 1988, operando uma nítida separação entre as funções de acusar, defender e julgar - a primeira, exclusiva do Ministério Público; a segunda, do advogado; a última, do juiz -, não conseguiu livrar-se de uma organização que confunde as duas carreiras.

(...)

O que deve preocupar - e o que realmente preocupa - é que por vezes o juiz italiano (o verdadeiro juiz) pareça mais próximo da acusação do que da defesa. Que possa vir a perder sua imparcialidade. Que tenha 
durante a investigação não têm caráter jurisdicional, pois objetivam justamente preparar o exercício da ação penal.

Sendo assim, as indagini preliminari consistem em procedimento judicial préprocessual, pois são coordenadas por ente vinculado ao Poder Judiciário e possuem caráter preparatório e instrumental em relação ao processo criminal.

A investigação inicia-se por meio do conhecimento espontâneo dos fatos pelo Ministério Público ou pela Polícia Judiciária, ou a partir de notícia de crime apresentada por terceiros (artigo 330 do Código de Processo Penal). Às vezes, a instauração da persecução preliminar depende de certas condições de procedibilidade, quais sejam: a querela, a instanza di procedimento, a richiesta di procedimento e a autorizzazione a procedere, reguladas nos artigos 336 a 346 do Código de Processo Penal.

A querela é própria dos delitos de iniciativa privada, consistindo em declaração de vontade da vítima ou de seu representante legal no sentido de que seja averiguada possível conduta criminosa. A instanza possui a mesma forma da querela, com a diferença de que se aplica aos crimes praticados no exterior e que podem ser investigados de ofício. A richiesta é um requerimento do Ministro da Justiça para instauração de procedimento investigatório destinado a apurar delitos específicos, expressamente previstos em lei. Por fim, certas pessoas, em razão do cargo que ocupam, apenas podem ser investigadas criminalmente se houver prévia autorização de autoridade competente: a denominada autorizzazione a procedere. ${ }^{298}$

Nas indagini preliminari, o Ministério Público é o responsável pela apuração dos fatos, com as atribuições estabelecidas nos artigos 358 a 378 da Lei Adjetiva Penal, a saber: $:^{299}$

o receber a notícia de crime e decidir sobre a instauração de procedimento investigatório;

o efetuar todas as atividades investigatórias necessárias ao exercício da ação penal, inclusive apurar fatos favoráveis ao sujeito passivo;

mais contatos com o Ministério Público do que com o advogado. Sim, porque afinal de contas o representante do Ministério Público é seu colega de carreira, pode ser o juiz de amanhã, e amanhã o juiz pode transformar-se em membro do parquet” ("Que juízes são esses?” in Boletim do Instituto Brasileiro de Ciências Criminais, n. ${ }^{\circ}$ 25, janeiro/1995, pp. 01/02).

${ }^{298}$ SIRACUSANO, Delfino, et alli, Elementi..., pp. 156/59. 
o interrogar o sujeito passivo na presença de um defensor (particular ou dativo);

o nomear assistentes técnicos para realizar exames periciais;

o ouvir pessoas capazes de esclarecer circunstâncias relevantes para a reconstrução dos fatos;

o proceder à individualização de pessoas e de coisas;

o ordenar, em caso de urgência, acareações, inspeções, seqüestros, buscas pessoais e locais e interceptações;

o encaminhar a informação de garantia (informazione di garanzia) ${ }^{300}$ ao sujeito passivo, antes da prática de qualquer ato para o qual se exige a presença de defensor;

o requisitar o comparecimento do sujeito passivo, do ofendido e de testemunhas, a atos que dependam de sua presença, sob pena de serem conduzidos coercitivamente;

o solicitar o arquivamento das investigações ou requerer a abertura de audiência preliminar;

o oferecer acusação formal.

Para a execução das diligências investigatórias, o Ministério Público, em virtude do disposto no artigo 378 do Código de Processo Penal, dispõe do poder coercitivo previsto no artigo 131 do aludido diploma legal. Consoante tais normas, o Ministério Público pode requerer a intervenção da Polícia Judiciária ou da Força Pública, prescrevendo tudo aquilo que é necessário para a realização segura e ordenada do ato investigatório.

A Polícia Judiciária tem função complementar à do Ministério Público e pratica atos investigatórios mediante delegação deste órgão, nos estritos termos do artigo 370 do Código de Processo Penal. Suas funções estão previstas nos artigos 347 a 357 do Código de Processo Penal, a saber: $:^{301}$

o receber a notícia de crime e transmiti-la ao Ministério Público;

o assegurar as fontes de prova, conservando o estado de lugares e de coisas e reunindo elementos úteis à reconstrução dos fatos e à individualização do sujeito passivo;

\footnotetext{
299 A respeito das funções do Ministério Público nas indagini preliminari, ver TONINI, Paolo, Manuale..., pp. 422/41 e DALIA, Andrea Antonio e FERRAIOLI, Marzia. Manuale di Diritto Processuale Penale. $4^{\text {a }}$ ed.. Milano: CEDAM, 2001, pp. 153/70 e pp. 472/91.

300 Trata-se de comunicado ao sujeito passivo da investigação preliminar, no qual são indicados os seus direitos, as normas violadas, a data e o lugar em que se produziu o fato e a faculdade de nomear defensor de confiança.

${ }^{301}$ A respeito das funções da Polícia Judiciária nas indagini preliminari, ver TONINI, Paolo, Manuale..., pp. 411/22 e DALIA, Andrea Antonio e FERRAIOLI, Marzia, Manuale..., pp. 171/80 e pp. 453/60.
} 
o identificar o sujeito passivo e as testemunhas;

o obter informações sumárias do sujeito passivo, que não se encontra em condições de ser detido, o qual deve estar acompanhado de seu defensor;

o tomar declarações espontâneas do sujeito passivo, que não poderão ser utilizadas na fase de dibattimento, salvo exceções previstas em lei;

o obter informações sumárias das testemunhas;

o realizar busca pessoal ou local, em caso de flagrante delito ou de evasão. O registro dessas diligências deve ser transmitido ao Ministério Público, no prazo de quarenta e oito horas, para a convalidação da medida;

o efetuar prisão em flagrante delito;

o apreender correspondência e documentos sigilosos e encaminhá-los intactos ao Ministério Público;

o verificar o estado de lugar e de coisas, se o Ministério Público não puder intervir imediatamente, e, se for o caso, realizar o seqüestro do corpo de delito e das coisas a ele pertinentes;

o elaborar relatório das atividades desenvolvidas e colocá-lo à disposição do Ministério Público.

Vale repisar que existe Juiz específico para a fase investigatória, diverso daquele que julgará o processo, chamado giudice per le indagini preliminari (GIP), que intervém apenas nos casos previstos em lei e a pedido das partes, não podendo atuar ex officio.

Tal Magistrado, como mencionado, não ultima ato investigatório. Sua função precípua é resguardar direitos e garantias fundamentais do sujeito passivo da investigação preliminar. Por conta disso, deve examinar a possibilidade de adoção de medidas restritivas desses direitos e, se for o caso, autorizá-las ou convalidá-las (se tiverem sido realizadas diretamente pelo Ministério Público ou pela Polícia Judiciária em regime de urgência). ${ }^{302}$

O GIP deve, ainda, fiscalizar a atividade desenvolvida pelo Ministério Público; decidir sobre os pedidos feitos por este órgão e pelas partes privadas, ${ }^{303}$ conforme previsto

\footnotetext{
302 SIRACUSANO, Delfino, et alli, Elementi..., pp. 167/70 e DALIA, Andrea Antonio e FERRAIOLI, Marzia, Manuale..., p. 26 e pp. 555/59.

303 No Direito italiano, entende-se por partes privadas (parti private) os sujeitos diversos da parte pública (Ministério Público). Assim, o conceito de partes privadas inclui o investigado, o acusado, o ofendido, a parte
} 
no artigo 328 do Código de Processo Penal; e conduzir o incidente de produção antecipada de provas e a audiência preliminar.

O sujeito passivo da investigação criminal é denominado, na Itália, de persona sottoposta alle indagini preliminari, vulgarmente conhecido como indagato. Em regra, adquire-se tal condição com a inscrição do nome no registro da notícia de crime arquivado junto ao cartório do Ministério Público. A qualidade de indagato mantém-se até o arquivamento da investigação ou início da ação penal. Neste último caso, o sujeito passivo passa a ser chamado de imputato, que é aquele que está sendo formalmente processado. ${ }^{304}$

O artigo 61 do Código de Processo Penal, com propósito claramente garantista, estende os direitos do imputato à persona sottoposta alle indagini preliminari. Além disso, o legislador italiano fixou várias prerrogativas específicas para este sujeito. ${ }^{305}$

O defensor da pessoa investigada possui direito de apresentar manifestações escritas endereçadas ao Ministério Público e de participar de certos atos das indagini preliminari (artigos 365 a 367 do Código de Processo Penal). Dentre estes, existem aqueles que não precisam ser comunicados previamente ao defensor (é o caso do seqüestro) e aqueles cuja execução válida depende de prévia comunicação ao defensor (atos que podem vir a ser utilizados na fase judicial, como os exames técnicos irrepetíveis, o interrogatório, a inspeção etc.). ${ }^{306}$

civil (aquele que sofreu prejuízos materiais devido à conduta ilícita), o responsável civil (aquele que está obrigado ao ressarcimento dos danos causados pelo crime) e a pessoa civilmente obrigada pela pena pecuniária. Nesse sentido, conferir SIRACUSANO, Delfino, et alli, Elementi..., pp. 47/59 e TONINI, Paolo, Manuale..., pp. 130/44.

${ }^{304}$ Conforme o artigo 60 do Código de Processo Penal, assume a qualidade de imputato aquele ao qual é atribuído o crime em algumas requisições específicas feita pelo Ministério Público, que levam à formal instauração de ação penal, a saber: richiesta di rinvio a giudizio, di giudizio immediato, di decreto penale di condanna, di applicazione della pena a norma dell'art. 447 comma 1, nel decreto di citazione diretta a giudizio e nel giudizio direttissimo. Sobre o status de imputato, ver DALIA, Andrea Antonio e FERRAIOLI, Marzia, Manuale..., pp. 181/85.

${ }^{305}$ Aury Lopes Jr. cita os principais direitos do sujeito passivo da investigação preliminar existentes no Código de Processo Penal italiano, a saber: (i) as suas declarações devem ser recebidas e valoradas com base em um ato oficial, com observância a todas as garantias legais; (ii) é proibida a utilização de métodos ou técnicas que podem influenciar a liberdade de autodeterminação ou alterar a capacidade de lembrar ou valorar os fatos; (iii) possibilidade de permanecer em silêncio; (iv) ter conhecimento dos elementos de prova que lhe são desfavoráveis; (v) oportunidade de expor tudo o que seja favorável à sua defesa; (vi) ser assistido por até dois defensores de sua confiança ou por um dativo; (vii) conversar reservadamente com o seu defensor; (viii) obter cópia dos autos pelo defensor; (ix) apresentar petições ao Ministério Público; e (x) receber a informazione di garanzia (Sistemas..., pp. 322/24).

${ }^{306}$ SIRACUSANO, Delfino, et alli, Elementi..., pp. 164/65. 
No tocante ao aspecto temporal, os artigos 405 a 407 do Código de Processo Penal prevêem prazos de duração máxima para a investigação criminal, sob pena de inutilização dos atos investigatórios (pena de inutilizzabilità). ${ }^{307}$

O artigo 373 do Código de Processo Penal prescreve os atos das indagini preliminari a serem registrados na forma escrita, salvo o disposto para atos específicos. Os autos referentes às indagini preliminari são conservados junto ao cartório do Ministério Público.

Ressalte-se que inexiste contraditório durante as indagini preliminari. Por conseguinte, os atos realizados nessa fase, em regra, não consubstanciam atos de prova, mas meros atos de investigação. Como tais, são aptos a fundamentar apenas as medidas judiciais tomadas ao longo da persecução prévia e o advento ou não da ação penal. ${ }^{308}$

Excepcionalmente, admite-se a produção de provas na investigação preliminar, aproveitáveis na fase processual, desde que sejam relevantes e exista risco de perecimento. Neste caso, deve se proceder ao incidente processual específico, com a participação do defensor do imputado (artigos 392 a 404 do Código de Processo Penal). ${ }^{309}$

\footnotetext{
${ }^{307}$ Como regra geral, o prazo máximo para a conclusão das indagini preliminari é de dezoito meses, salvo se pendente a realização de incidente probatório. Em alguns casos, tal prazo é dilatado para dois anos (artigo 407 do Código de Processo Penal). A partir da inscrição do nome do suspeito no registro da notícia de crime, a investigação deve se encerrar em seis meses, prorrogáveis por igual período. Se a complexidade dos fatos exigir período maior de investigação, pode haver nova prorrogação por seis meses, desde que o Juiz das indagini tenha autorização do órgão colegiado (artigos 405 e 406 do Código de Processo Penal).

${ }^{308}$ SIRACUSANO, Delfino, et alli, Elementi..., pp. 166/67. Segundo Fauzi Hassan Choukr, o legislador italiano, para compensar a ausência de contraditório na indagini preliminari, procurou evitar ao máximo a intromissão em juízo dos elementos informativos coletados nessa fase; bem como garantir, na medida do possível, a participação da defesa técnica e transformar em incidentes jurisdicionais todos os atos que importem natureza cautelar, seja de caráter patrimonial ou pessoal (Garantias..., pp. 115/116).

${ }^{309} \mathrm{O}$ incidente de produção antecipada de provas pode ser requerido pelo Ministério Público ou pelo sujeito passivo da investigação preliminar, nos casos previstos no artigo 392 do Código de Processo Penal: (i) colher depoimento de testemunha, quando existirem fundados motivos de que esta pessoa não poderá testemunhar na fase de dibattimento por enfermidade ou outro motivo grave; (ii) colher depoimento de testemunha, quando, a partir de elementos concretos e específicos, existirem fundados motivos para se concluir que tal pessoa seja exposta à violência, ameaça, oferta ou promessa de dinheiro ou outra utilidade, com o objetivo de não prestar depoimento ou falseá-lo; (iii) ouvir o sujeito passivo sobre fatos concernentes à responsabilidade de outros; (iv) ouvir pessoa acusada em procedimento conexo; (v) realizar acareação de pessoas que prestaram declarações divergentes em outro incidente probatório ou para o Ministério Público; (vi) realizar perícia ou reconstituição do fato, se a prova refere-se à pessoa, coisa ou lugar, sujeito à modificação inevitável; (vii) realizar reconhecimento pessoal, quando particulares razões de urgência não autorizam a execução do ato na fase de dibattimento; (ix) realizar perícias que poderiam suspender a fase de dibattimento por período superior a 60 (sessenta) dias. Tal incidente desenvolve-se em audiência judicial, sob o crivo do contraditório. O seu resultado é transmitido ao Ministério Público, sendo que o defensor do sujeito passivo tem direito à vista e extração de cópia. As provas obtidas por meio do incidente probatório podem ser utilizadas na fase de dibattimento apenas com relação ao acusado cujo defensor tenha participado do incidente.
} 
Ao cabo das investigações, o Ministério Público, se não vislumbrar indícios suficientes de autoria e materialidade delitiva, solicita o arquivamento da persecução prévia. Também deve requerer o arquivamento em caso de atipicidade dos fatos investigados, se houver causa extintiva de punibilidade ou faltar condição de procedibilidade (artigos 408 e seguintes do Código de Processo Penal).

Tal pedido é apreciado pelo GIP que, se estiver de acordo, determina o arquivamento por meio do decreto di archiviazione ou, se divergir, designa audiência para discutir, sob o contraditório das partes, a subsistência das razões de arquivamento.

Se o Ministério Público verificar a presença dos pressupostos formais e materiais para o prosseguimento do caso, deve exercitar a ação penal. Nesta hipótese, o Parquet, primeiramente, comunica o sujeito passivo e seu defensor do encerramento da fase investigatória. Em seguida, requer a designação de audiência preliminar, normalmente por meio da richiesta di rinvio a giudizio, espécie de imputação em face de pessoa determinada. $^{310}$

O aviso de conclusão das indagini preliminari, previsto no artigo 415-bis do Código de Processo Penal, é ato de extrema importância para o sujeito passivo. Por meio dele, descreve-se, resumidamente, a imputação e cientificam-se o sujeito passivo e seu defensor de que os autos das indagini preliminari estão depositados junto ao cartório do Ministério Público, podendo ser consultados e fotocopiados. Além disso, deve constar do aviso a faculdade de o sujeito passivo, no prazo de vinte dias, apresentar memoriais, produzir documentos, depositar a documentação relativa à investigação defensiva, requerer ao Ministério Público a realização de atos de investigação e prestar depoimento ou ser interrogado.

Esclarece Eraldo Stefani que tal aviso tem duas finalidades: de um lado, garantir o direito de defesa do indagato; de outro, garantir a completude das investigações preliminares, evitando o exercício de ação penal inútil. ${ }^{311}$

\footnotetext{
${ }^{310}$ Tal imputação é composta pela enunciação, de forma clara e precisa, do fato histórico do crime e pela indicação das normas jurídicas violadas e da pessoa que teria praticado a infração penal. Existem, ainda, outros tipos de formulação de imputação que podem ser adotados pelo Ministério Público, atinentes a procedimentos especiais (SIRACUSANO, Delfino, et alli, Elementi..., p. 173 e TONINI, Paolo, Manuale..., p. 107).

${ }^{311}$ STEFANI, Eraldo, Codice..., p. 351.
} 
A audiência preliminar, regulada nos artigos 416 a 433 do Código de Processo Penal, desenvolve-se perante o GIP, sendo o momento em que se discute a viabilidade da acusação, isto é, o seu embasamento fático e jurídico. Para tanto, as partes fundamentam os seus argumentos nos elementos materiais que compõem o fascículo das indagini preliminari.

Consoante o artigo 419, 5, do Código de Processo Penal, o imputato pode renunciar à audiência preliminar por meio de declaração escrita, apresentada no ofício judicial ao menos três dias antes da data marcada para o ato. Nesse caso, o GIP emite decreto di giudizio immediato e encaminha o feito à apreciação do Juiz competente. ${ }^{312}$

Por outro lado, no curso da audiência preliminar, se a Autoridade Judiciária vislumbra a presença dos requisitos formais e materiais, recebe a acusação por meio do decreto che dispone il giudizio e determina a formação do fascículo do dibattimento, dando início ao processo criminal.

O artigo 431 do Código de Processo Penal enuncia os elementos que compõem o fascículo do dibattimento, quais sejam: os atos relativos à procedibilidade da ação penal e ao exercício da ação civil; os registros dos atos não repetíveis realizados pela Polícia Judiciária, pelo Ministério Público e pelo defensor; os registros dos atos realizados no incidente probatório; e o corpo de delito e os elementos pertinentes ao crime. Os demais dados obtidos na investigação preliminar não integram os autos do processo, para evitar a contaminação do convencimento do Juiz da causa.

No entanto, ocorreram alterações legislativas na Itália, em particular a Lei n. ${ }^{\circ}$ 356, de 07 de agosto de 1992, que permitiram ao Juiz da causa formar a sua opinião com informes resultantes das indagini preliminari. ${ }^{313} \mathrm{O}$ mencionado estatuto legal realizou algumas modificações no Código de Processo Penal, para instituir medidas de combate à criminalidade mafiosa. Dentre estas, admitiu o uso, na fase de dibattimento, de declarações prestadas por testemunhas na investigação preliminar.

\footnotetext{
312 Para alguns crimes com procedimento especial previsto em lei, é possível a instauração de processo criminal sem prévia audiência preliminar.

313 BADARÓ, Gustavo Henrique Righi Ivahy, Ônus da prova..., pp. 141/42 e AMODIO, Ennio, "Vitórias e derrotas da cultura dos juristas na elaboração do novo Código de Processo Penal”..., p. 22.
} 


\section{V.2.2. O surgimento da investigação criminal defensiva na Itália}

Com a reforma processual que outorgou às partes a gestão da prova, a defesa deixou de ser figura inerte na persecução penal, que se limitava a examinar os elementos oriundos da instrução, e passou a ter posição ativa, sendo dotada de poderes para buscar fontes de prova em favor do sujeito passivo. ${ }^{314}$

Para tanto, previu-se a possibilidade de a defesa participar das indagini preliminari conduzidas pelo Ministério Público, como analisado, ou desenvolver investigação própria, independente da investigação pública. ${ }^{315}$

A investigação defensiva, na Itália, denomina-se investigazioni difensive ou indagini difensive e encontra respaldo constitucional nos artigos 24, 2, e 111 da Constituição da República. O primeiro estabelece, genericamente, o direito de defesa; ao passo que o segundo prevê que o sujeito passivo deve dispor do tempo e das condições necessárias para preparar a defesa e pode adquirir qualquer meio de prova a seu favor. ${ }^{316}$

No âmbito legal, o artigo 190 do Código de Processo Penal, que consagrou o direito à prova, constitui o pressuposto básico da investigação defensiva. Salienta Paolo Tonini que "il diritto alla prova spetta sia al pubblico ministero, sia alle parti private. Per poter funzionare correttamente un sistema processuale di tipo accusatorio deve necessariamente consentire l'investigazione difensiva; e cioè deve permettere ai difensori delle parti private di ricercare le fonti, di acquisire gli elementi di prova e di presentarli al giudice”. 317

A investigação defensiva surgiu para contrabalançar o viés acusatório das indagini preliminari, dirigidas pelo Ministério Público. Aponta José Barcelos de Souza que “o pensamento da instituição da investigação também pela defesa foi, na Itália, fruto da

\footnotetext{
${ }^{314}$ Conforme ressaltado por Nicola Triggiani, “si é passati da una 'difesa di posizione' - consistente nell’ osservare il pubblico ministero, il giudice istruttore e poi addirittura il presidente che dipana le prove, in una vigile, attenta, intelligente, ma, di regola, passiva atesa circa il momento più propizio nel quale intervenire per assestare un qualche 'colpo' utile per la difesa - a una 'difesa di movimento', che impone al difensore di avere presente fin dall'inizio un progetto di difesa e di costruire a seconda delle contingenze, una o più ipotesi alternative lungo le quali sviluppare la difesa, nella consapevolezza delle risorse probatorie disponibili” (Le investigazioni difensive. Milano: Giuffrè, 2002, p. 02).

${ }^{315}$ VENTURA, Pasquale, Le indagini..., p. 09.

${ }^{316}$ Pietro Gatto explica a legitimação constitucional da investigação defensiva no Direito italiano, com especial destaque para o artigo 111 da Constituição da República (Le investigazioni preventive del difensore. Milano: Giuffrè, 2003, pp. 15/20).

${ }^{317}$ TONINI, Paolo, Manuale..., p. 493.
} 
verificação de que o Ministério Público, a quem fora passada a supervisão da investigação, conservava uma tendência natural de parte, posto devesse em tese também colher elementos do interesse da defesa”. 318

Todavia, há quem entenda que a investigação defensiva não foi suficiente para garantir a desejada paridade de armas entre as partes, pois "a defesa, no curso da indagine preliminare, encontra-se em posição de nítida inferioridade em relação à acusação, não só pela dificuldade, de ordem essencialmente prática para desenvolver uma autônoma atividade investigatória, voltada à descoberta de fontes de provas a favor do investigado, mas sobretudo pela relevância que tem no dibattimento muitos dos atos atribuídos ao Ministério Público”. 319

A possibilidade de o defensor reunir elementos de conviç̧ão em favor do assistido foi, a princípio, contemplada no artigo 38 das disposições de atuação do Código de Processo Penal, que facultava ao defensor apresentar diretamente ao Juiz os dados reunidos na investigação privada. ${ }^{320}$

Ocorre que a jurisprudência interpretou restritivamente o referido artigo, esposando que o resultado da investigação defensiva não era diretamente utilizável como

\footnotetext{
318 “Poderes da defesa na investigação e investigação pela defesa”..., p. 02.

319 BADARÓ, Gustavo Henrique Righi Ivahy, Ônus da prova..., p. 145. Alessandro Nocetti também afirma que a paridade substancial de armas entre as partes, nas investigações preliminares, não foi atingida por meio da investigação defensiva. De um lado, porque os advogados, ao invés de desenvolverem atividade investigatória, preferem esperar o resultado da persecução prévia e atuar na fase de debates ou em sede de incidente probatório, de outro, em razão dos limites legais. O autor menciona, ainda, que o elevado custo da atividade investigatória provocaria, no plano substancial, evidente disparidade entre as partes. Enquanto o Ministério Público tem, à sua disposição e sem qualquer custo, uma gama de sujeitos para lhe auxiliar nas indagini preliminari; o cidadão, para uma investigação eficaz, deve contratar assistentes técnicos, a custos elevados, o que por vezes inviabiliza tal atividade (NOCETTI, Alessandro. "Indagini difensive, parità sostanziale o finzione normativa?”, p. 01. Disponível na internet: “www.criminologia.it/diritto”. Acesso em 14 de setembro de 2008).

${ }^{320}$ Vale conferir o teor deste dispositivo, verbis: “Al fine di esercitare il diritto alla prova previsto dall'art. 190 del Codice, i difensori, anche a mezzo di sostituti e di consulenti tecnici, hanno facoltà di svolgere investigazioni per ricercare e individuare elementi di prova a favore del proprio assistito e di conferire con le persone che possano dare informazioni”. Segundo Glauco Giostra, tal norma era tecnicamente fraca, pois não cuidou de aspectos essenciais à investigação defensiva, como, por exemplo, os limites da atividade investigatória, o modo de obtenção e de documentação dos elementos de prova, a utilização desses dados e o poder de controle do Juiz acerca da genuinidade da documentação defensiva ("Problemi irrisolti e nuove prospettive per il diritto di difesa: dalla registrazione delle notizie di reato alle indagini difensive” in Politica del Diritto, Ano XXVIII, n. ${ }^{\circ}$ 2, junho 1997, pp. 159/61). No mesmo sentido: APRILE, Ercole e SILVESTRI, Pietro. La formazione della prova penale - dopo le leggi sulle indagini difensive e sul "giusto processo". Milano: Giuffrè, 2002, pp. 09/14.
} 
elemento de prova e, por isso, deveria ser direcionado ao Ministério Público (teoria da canalização). ${ }^{321}$

Diante disso, foi editada a Lei n. ${ }^{\circ}$ 332, de 08 de agosto de 1995, que garantiu ao defensor o direito de apresentar ao Juiz os meios de prova obtidos com sua investigação. Além disso, impôs ao Magistrado o dever de inserir essa documentação nos autos das investigações preliminares.

Posteriormente, elaborou-se a Lei n. ${ }^{\circ}$ 479, de 16 de dezembro de 1999, que previu o dever do Ministério Público de fazer constar do aviso de conclusão das indagini preliminari a faculdade de o sujeito passivo depositar a documentação relativa à investigação defensiva.

Em seguida, a Lei n. ${ }^{\circ}$ 397, de 07 de dezembro de 2000, alterou diversos artigos do Código de Processo Penal, para regulamentar, de maneira detalhada, a investigação defensiva. ${ }^{322}$ Na verdade, este diploma legal objetivou reequilibrar a posição das partes na persecução prévia, atribuindo ao defensor poderes investigatórios já previstos para o Ministério Público e a Polícia Judiciária.

Hoje, a investigação defensiva, além de ser tema bastante estudado pela doutrina italiana, vem sendo cada vez mais utilizada pelos defensores para buscar elementos de prova favoráveis aos assistidos. Prova disso é que existe portal jurídico italiano específico sobre a investigação defensiva, cujo endereço virtual é “www.indaginidifensive.it”. Em tal site, constam obras doutrinárias e julgados relacionados à investigação defensiva, bem como modelos dos principais atos que podem ser executados ao longo deste procedimento.

Como destacado por Paolo Tonini, ${ }^{323}$ a investigação defensiva é, ao mesmo tempo, direito e dever do advogado. É direito com relação à Autoridade Judiciária, que deve permitir a sua livre realização. É dever com relação ao cliente, pois a investigação defensiva pode ser necessária para a efetiva tutela de seus interesses.

\footnotetext{
${ }^{321}$ No começo da década de 90, a Suprema Corte italiana sustentava a teoria da canalização, segundo a qual todos os dados obtidos na fase de investigação preliminar, inclusive os elementos resultantes da investigação defensiva, deveriam ser canalizados no Ministério Público. A esse respeito, conferir VENTURA, Pasquale, Le indagini..., p. 08/16 e TRIGGIANI, Nicola, Le investigazioni..., pp. 30/55.

${ }^{322}$ Sobre os antecedentes doutrinários e jurisprudenciais que culminaram na elaboração desta lei, conferir RUGGIERO, Giuseppe. Compendio delle investigazioni difensive. Milano: Giuffrè, 2003, pp. 34/78.
} 
Importa, no presente trabalho, examinar as normas existentes no ordenamento jurídico italiano a respeito da investigação defensiva e as principais questões suscitadas sobre a sua aplicação.

\section{V.2.3. O tratamento legislativo da investigação criminal defensiva na Itália}

A Lei n. ${ }^{\circ}$ 397/2000 inseriu novos dispositivos e alterou substancialmente diversos artigos do Código de Processo Penal italiano, com o objetivo de disciplinar os principais aspectos relacionados à investigação defensiva e criar procedimento próprio para a sua efetivação. Com isso, o legislador italiano pretendeu viabilizar a investigação defensiva, que, até então, era mera previsão abstrata, sem qualquer tipo de regulamentação. ${ }^{324}$

O legislador italiano objetivou, também, restabelecer a paridade de armas entre as partes na persecução penal, prevendo a possibilidade de o defensor efetuar atos investigatórios similares aos do Ministério Público e da Polícia Judiciária e atribuindo o mesmo valor probatório para o resultado da investigação defensiva e o da investigação pública.

Inicialmente, o artigo 327-bis do Código de Processo Penal estipulou que o defensor ou seu substituto, auxiliado ou não por assistente técnico ou investigador privado autorizado, ${ }^{325}$ pode realizar atividade de investigação, com o objetivo de descobrir e individualizar elementos de prova favoráveis ao próprio assistido. In verbis: "Fin dal momento dell'incarico professionale, risultante da atto scrito, il difensore ha facoltà di

\footnotetext{
${ }^{323}$ TONINI, Paolo, Manuale..., p. 495.

${ }^{324}$ A regulamentação da investigação defensiva pela Lei n. ${ }^{\circ}$ 397/2000 não é exaustiva, sendo completada pelas Regole di comportamento del penalista nelle investigazioni difensiva, cujo texto foi aprovado, em $14 \mathrm{de}$ julho de 2001, pela Unione Camere Penali Italiane (associação italiana de advogados criminalistas) - o inteiro teor deste texto foi transcrito no apêndice legislativo deste trabalho. Tais regras possuem valor convencional, isto é, vinculam somente os advogados inscritos nas Câmeras Penais. Além disso, em 26 de outubro de 2002, o Consiglio Nazionale Forense, órgão de representação institucional da advocacia, introduziu modificações ao Código Deontológico, com o objetivo de disciplinar o desenvolvimento da investigação defensiva. A violação destas disposições é punida com sanções disciplinares (TONINI, Paolo, Manuale..., pp. 394/95 e TRIGGIANI, Nicola, Le investigazioni..., pp. 78/88).

${ }^{325} \mathrm{O}$ investigador privado autorizado é uma figura prevista no artigo 222 das disposições de atuação do Código de Processo Penal. Trata-se de investigador privado especialmente qualificado, que, após adquirir certa maturidade profissional, obtém autorização para exercer investigação defensiva, expedida pelo Prefeito da província onde irá atuar.
} 
svolgere investigazioni per ricercare ed individuare elementi di prova a favore del proprio assistito, nelle forme e per le finalità stabilite nel titolo VI-bis del presente libro”.

Vê-se que a iniciativa investigatória pertence ao defensor e não ao assistido. O defensor é o dominus da investigação defensiva, tendo a direção, o controle e a responsabilidade por esta atividade. ${ }^{326}$

Além disso, conforme a mencionada norma, a investigação defensiva pode ser ultimada pelo defensor do assistido em geral e não exclusivamente pelo da persona sottoposta alle indagini preliminari. Logo, o defensor de qualquer uma das partes privadas (investigado, acusado, vítima, parte civil, responsável civil e pessoa civilmente obrigada pela pena pecuniária), pode investigar, a partir do momento em que recebe, por ato escrito, o encargo profissional. ${ }^{327}$ Por isso é que, na Itália, a expressão investigação defensiva possui acepção mais ampla do que a utilizada neste trabalho, sendo equiparada à investigação privada e não apenas àquela realizada pelo defensor do sujeito passivo da persecução penal.

Esta atividade investigatória pode ser promovida por defensor particular ou dativo, ${ }^{328}$ em qualquer estado e grau da persecução criminal, na execução penal, para promover a revisão criminal e até mesmo de forma preventiva, caso exista a possibilidade de instauração de procedimento criminal. Em suma, o defensor pode investigar sempre que houver a necessidade de procurar elementos de prova favoráveis ao assistido, não obstante esta atividade se manifestar com maior freqüência na fase de persecução prévia.

Outrossim, foram modificadas algumas regras do Código de Processo Penal, com o propósito de ajustar o rito do processo criminal à investigação defensiva, a saber:

\footnotetext{
326 TRIGGIANI, Nicola, Le investigazioni..., p. 104.

${ }^{327}$ Nessa linha, aduz Ivano Lai que "la legge n. 397 del 2000 non fa distinzione tra difensori: non si riferisce né al difensore della persona sottoposta alle indagini, né al difensore dell'imputato, né a quello di altri soggetti privati, come la persona offesa, ma riguarda indistintamente il difensore di ognuno di essi. Con ciò si è voluto intendere che i poteri, i diritti, le facoltà collegati al ruolo del difensore sono i poteri, i diritti, le facoltà del difensore di uno qualunque dei soggetti che hanno l'obbligo o la facoltà di essere assistiti e rappresentati nel procedimento" ("Le investigazioni difensive nei reati di criminalità organizzata” in $L a$ Giustizia Penale 2003 (parte terza: Procedura Penale), p. 123). Conferir, também, TAORMINA, Carlo, Il regime..., pp. 158/59; VENTURA, Pasquale, Le indagini..., pp. 25/26 e RUGGIERO, Giuseppe, Compendio..., pp. 95/113.

328 Pasquale Ventura salienta a necessidade de se nomear defensor dativo para realizar investigação defensiva, no caso de o sujeito passivo não possuir condições econômicas para arcar com advogado particular (Le indagini..., pp. 21/23). No mesmo sentido: TRIGGIANI, Nicola, Le investigazioni..., pp. 93/95.
} 
o artigo 103, 2, do Código de Processo Penal: proibiu o seqüestro de documentos em poder do defensor, do investigador privado autorizado e do assistente técnico, salvo se constituírem corpo de delito;

o artigo 116, 3-bis, do Código de Processo Penal: previu que o defensor, ao apresentar qualquer informação à Autoridade Judiciária - inclusive o resultado material de sua investigação - tem direito à emissão de atestado e pode extrair cópia do que foi depositado;

o artigos 197, 1, “d”, e 200, 1, “b”, do Código de Processo Penal: vetaram a inquirição, como testemunha, do defensor, do investigador privado autorizado e do assistente técnico, por estarem acobertados pelo sigilo profissional;

o artigo 233, 1-bis, do Código de Processo Penal: instituiu o direito das partes privadas à prova técnico-científica, consistente na possibilidade de o defensor indicar assistente técnico para (i) examinar as coisas seqüestradas no lugar em que se encontram, (ii) intervir em inspeções ou (iii) examinar o objeto de inspeções que não presenciou. Tal pedido de assistência técnica deve ser autorizado pelo Ministério Público, na fase de investigação preliminar, ou pela Autoridade Judiciária, após o início da ação penal;

o artigo 362, 1, do Código de Processo Penal: proibiu o Ministério Público, ao ouvir pessoas que prestaram depoimento na investigação defensiva, de indagar sobre as questões formuladas pelo defensor e suas respectivas respostas.

Merece especial destaque a criação do título VI-bis no livro quinto do Código de Processo Penal, composto de nove artigos (391-bis a 391-decies), que indicaram as ações cabíveis na investigação defensiva, a seguir analisadas.

- Artigo 391-bis: colóquio, recebimento de declarações e obtenção de informações por parte do defensor.

O defensor, o investigador privado autorizado ou o assistente técnico podem promover colóquio não documentado, consistente na entrevista pessoal e informal de pessoas capazes de fornecer dados úteis aos fins da investigação. Não podem ser 
entrevistados aqueles que são incompatíveis com a condição de testemunha, como previsto no artigo 197, 1, “c” e “d”, do Código de Processo Penal. ${ }^{329}$

O defensor pode, ainda, pedir declaração escrita às pessoas entrevistadas ou que prestem informações a serem documentadas na forma do artigo 391-ter do Código de Processo Penal. Tais medidas não podem ser praticadas pelo assistente técnico ou pelo investigador privado autorizado, pois dizem respeito diretamente à estratégia de defesa, de responsabilidade exclusiva do causídico. Em outras palavras, apenas o defensor é capaz de avaliar e selecionar os elementos favoráveis ao assistido e que precisam ser documentados.

Para evitar qualquer tipo de coação sobre o depoente, proíbe-se a participação do investigado, da vítima e de outras partes privadas, nos atos supramencionados. ${ }^{330}$

Antes de se proceder à entrevista pessoal, o depoente deve ser avisado da qualidade e da finalidade da oitiva; da modalidade e da forma de documentação; do dever de informar se figura como indagato ou imputato no mesmo procedimento, ou procedimento conexo ou por crime coligado; da faculdade de não responder às indagações e de não prestar declaração; da proibição de revelar as perguntas eventualmente formuladas pela Polícia Judiciária ou pelo Ministério Público e as respostas dadas; e da responsabilidade penal decorrente da falsa declaração.

Se o depoente decidir responder às questões formuladas, tem o dever de dizer a verdade, sob pena de incorrer no crime de falso testemunho, previsto no artigo 371-ter do Código Penal.

Por outro lado, se o depoente fizer uso da faculdade de não responder às indagações, total ou parcialmente, ou de não prestar declaração, restam duas opções ao defensor: (i) requerer ao Ministério Público a sua inquirição, no prazo máximo de sete dias contado da data da apresentação do requerimento; ${ }^{331}$ ou (ii) requerer a instauração de

\footnotetext{
${ }^{329}$ Este dispositivo proíbe a inquirição, como testemunha, do responsável civil e da pessoa civilmente obrigada pela pena pecuniária; daqueles que, no mesmo procedimento, funcionaram como Juiz, Ministério Público ou seu auxiliar; do defensor que desenvolveu atividade de investigação defensiva; e daqueles que formaram a documentação das declarações e informações obtidas conforme o artigo 391-ter do Código de Processo Penal.

${ }^{330}$ TONINI, Paolo, Manuale..., pp. 504/05 e APRILE, Ercole e SILVESTRI, Pietro, La formazione..., p. 68.

${ }^{331}$ Esta prescrição é bastante criticada pela doutrina italiana, pois o fato de o defensor ter que recorrer ao Ministério Público para ouvir uma pessoa fere os princípios da paridade de armas e da ampla defesa, que amparam a investigação defensiva. Além disso, obriga o defensor a revelar ao Ministério Público, prematuramente, alguns aspectos de sua estratégia de defesa (TAORMINA, Carlo, Il regime..., p. 165).
} 
incidente probatório para a obtenção do depoimento. ${ }^{332}$ A primeira providência cabe apenas contra testemunhas, enquanto a segunda cabe contra testemunhas e pessoas investigadas ou acusadas no mesmo procedimento. ${ }^{333}$

No curso da entrevista, se surgirem indícios de crime imputável ao depoente, o defensor deve imediatamente interromper o ato. Essas declarações não podem ser utilizadas contra o depoente, mas são válidas contra terceiros.

É possível ouvir quem figura como investigado ou acusado no mesmo procedimento, ou em procedimento conexo ou por crime coligado, desde que o seu defensor seja comunicado com antecedência mínima de vinte e quatro horas e esteja presente no ato. Se a pessoa a ser ouvida não possuir advogado constituído, deve ser requerida ao Juiz a nomeação de defensor dativo para acompanhar o ato.

Para a inquirição de alguém detido, o defensor deve obter, previamente, autorização do Juiz competente, ouvidos o defensor do preso e o Ministério Público.

A violação dos requisitos previstos nesta norma acarreta a inutilização processual das declarações e informações obtidas e a responsabilização disciplinar do sujeito infrator.

- Artigo 391-ter: documentação das declarações e das informações.

O defensor pode formar instrumento para documentar as declarações e informações obtidas conforme o artigo 391-bis do Código de Processo Penal. Esta atividade de documentação não pode ser feita pelo investigador privado autorizado ou pelo assistente técnico.

No caso de declaração, o defensor deve efetuar a sua autenticação e redigir relatório no qual devem constar os seguintes dados: a data em que recebeu a declaração; os dados pessoais próprios e do depoente; a afirmação de ter feito o aviso mencionado no

\footnotetext{
${ }^{332}$ Trata-se de incidente probatório sui generis, porque o Juiz não precisa verificar a presença das condições que justifiquem a antecipação da prova, estipuladas no artigo 392 do Código de Processo Penal. Para a instauração deste incidente, o Juiz deve somente examinar se o defensor respeitou todas as formalidades para a obtenção de informações ou declaração do depoente (APRILE, Ercole e SILVESTRI, Pietro, La formazione..., p. 83).

333 O defensor pode recorrer ao Ministério Público ou à Autoridade Judiciária também nos casos em que a pessoa não comparece ao depoimento (TONINI, Paolo, Manuale..., p. 509 e TRIGGIANI, Nicola, Le investigazioni..., pp. 314/15).
} 
artigo 391-bis do Código de Processo Penal; e os fatos objeto da declaração. A declaração deve ser anexada a este relatório.

Por sua vez, as informações prestadas pelo depoente devem ser documentadas pelo defensor por meio de ata, observando as regras gerais do Código de Processo Penal sobre a matéria. Para a redação desta ata, o defensor pode se valer de pessoas de sua confiança.

Não há regra expressa sobre a forma como o defensor deve colher essas informações. Assim, pode solicitar ao depoente que narre livremente os fatos de que tem conhecimento ou pode conduzir a entrevista por meio de perguntas específicas.

Ao contrário do Ministério Público e da Polícia Judiciária que têm o dever de documentar seus atos investigatórios (artigos 357 e 373 do Código de Processo Penal), o defensor registra formalmente o resultado de sua investigação apenas se entender conveniente para o seu cliente.

Contudo, se o defensor decidir elaborar o instrumento, deve documentar fielmente todas as perguntas e respostas dadas, sem deturpar o seu teor. Além disso, se optar por apresentar a documentação ao Juiz, deve fazê-lo integralmente, isto é, sem eliminar trechos desfavoráveis ao assistido. ${ }^{334}$

- Artigo 391-quater: requisição de documentos à Administração Pública.

Este artigo permite ao defensor solicitar documentos em poder da Administração Pública e deles extrair cópia às suas expensas. Este requerimento deve ser dirigido ao órgão que elaborou o documento ou àquele que o detém.

Em caso de recusa, o defensor pode requerer ao Ministério Público que determine a aquisição coativa do documento junto ao órgão público. Se o Parquet indeferir o pedido do defensor, deve encaminhá-lo ao GIP, com o seu parecer negativo, nos termos dos artigos 367 e 368 do Código de Processo Penal. O Juiz pode ordenar o seqüestro do documento junto à Administração Pública.

334 TONINI, Paolo, Manuale..., p. 505; APRILE, Ercole e SILVESTRI, Pietro. Le indagini preliminari e l'archiviazione (artt. 326-415-bis cod. proc. pen.). Milano: Giuffrè, 2004, pp. 524/27 e VENTURA, Pasquale, Le indagini..., p. 142. 
A lei é omissa a respeito da requisição de documentos em poder de sujeitos privados. Nesta hipótese, se não houver colaboração do particular, o defensor deve requerer à Autoridade Judiciária o seqüestro do documento, conforme os citados artigos 367 e 368 do Código de Processo Penal. ${ }^{335}$

- Artigo 391-quinquies: poder de sigilo do Ministério Público.

Se for necessário ao desenvolvimento da sua atividade de investigação, o Ministério Público pode, por meio de decreto motivado, proibir que os depoentes informem ao defensor ou seus auxiliares fatos e circunstâncias investigadas dos quais tenham conhecimento. ${ }^{336}$

Tal vedação pode durar, no máximo, dois meses e deve ser comunicada ao depoente, com a advertência de que o seu descumprimento configura o delito de violação de segredo, tipificado no artigo 379-bis do Código Penal.

\section{- Artigo 391-sexies: acesso a lugares e documentos.}

O defensor, o assistente técnico ou o investigador privado autorizado podem ter acesso a locais públicos ou abertos ao público, ${ }^{337}$ com o propósito de verificar o estado de lugares e de coisas, ou de proceder a sua descrição ou de executar exames técnicos, gráficos, planimétricos, fotográficos.

Neste caso, deve-se elaborar ata com os seguintes elementos: a data e o lugar do acesso; os dados pessoais próprios e das pessoas que participaram da diligência, que também devem subscrever a ata; a descrição do estado do lugar e das coisas; e a indicação dos eventuais exames técnicos, gráficos, planimétricos, fotográficos ou audiovisuais efetuados.

\footnotetext{
${ }^{335}$ RUGGIERO, Giuseppe, Compendio..., p. 269 e TRIGGIANI, Nicola, Le investigazioni..., pp. 350/51.

${ }^{336}$ Por meio deste artigo, busca-se resguardar a investigação pública, quando colide com a investigação defensiva. Para alguns juristas, esta norma é inoportuna, porque afronta a paridade de armas entre as partes, que foi o objetivo principal da reforma legislativa que instituiu a investigação defensiva (APRILE, Ercole e SILVESTRI, Pietro, La formazione..., p. 85/86; RUGGIERO, Giuseppe, Compendio..., pp. 271/75 e CESETTI, Marco. "Investigazioni difensive: luci ed ombre", p. 01. Disponível na internet: "www.giuridicamente.com/investigazioni”. Acesso em 22 de setembro de 2008).

${ }^{337}$ Locais públicos são aqueles de acesso constantemente livre, de direito e de fato, a um número indeterminado de pessoas, sem qualquer tipo de limitação ou condição. Por sua vez, locais abertos ao público são aqueles acessíveis somente em certos momentos ou mediante o cumprimento de determinadas condições (VENTURA, Pasquale, Le indagini..., p. 109).
} 
Um limite objetivo para a execução desse ato investigatório é a imutabilidade do lugar examinado. Caso seja inevitável a alteração do lugar, deve-se proceder na forma prevista para exames técnicos não repetíveis (artigo 391-decies do Código de Processo Penal). ${ }^{338}$

Se a Polícia Judiciária e o defensor pretenderem vistoriar o mesmo lugar, ao mesmo tempo, prevalece a atividade policial, devido ao interesse público de conservar o local do crime e recolher elementos acerca do ilícito penal. ${ }^{339}$

- Artigo 391-septies: acesso a lugares privados ou não abertos ao público.

O defensor pode ingressar em lugares privados ou não abertos ao público ${ }^{340}$ para realizar as diligências mencionadas no artigo anterior, desde que haja concordância por parte de quem tem a disponibilidade do lugar. Se não existir tal permissão, o defensor pode requerer autorização de acesso ao Juiz, que deve proferir decisão fundamentada.

Não é permitido o ingresso em lugares de habitação e seus anexos, salvo se for necessário para verificar vestígios e outros efeitos materiais do crime e exista autorização judicial.

A pessoa responsável pelo local vistoriado deve ser comunicada da faculdade de ser assistida por pessoa de confiança, desde que esta já se encontre no local e seja idônea nos termos do artigo 120 do Código de Processo Penal. ${ }^{341}$

- Artigo 391-octies: fascículo do defensor.

O defensor, no curso das indagini preliminari e da audiência preliminar, pode apresentar diretamente ao Magistrado os elementos de prova favoráveis ao assistido. Esta faculdade pode ser exercida no momento em que o Juiz deve proferir decisão com a intervenção da parte privada patrocinada pelo defensor (v.g. decisão de arquivamento); ou

\footnotetext{
${ }^{338}$ RUGGIERO, Giuseppe, Compendio..., pp. 291/93.

339 APRILE, Ercole e SILVESTRI, Pietro, La formazione..., p. 96 e TRIGGIANI, Nicola, Le investigazioni..., pp. 355/56.

${ }^{340}$ Constituem lugares privados a residência com seus anexos e todos aqueles em que se exerce, ainda que de modo transitório e contingente, atividade privada. Lugares não abertos ao público são aqueles pertencentes à Administração Pública cujo ingresso, normalmente, é vetado (TRIGGIANI, Nicola, Le investigazioni..., p. 359).

${ }^{341}$ De acordo com este artigo, não podem intervir como testemunhas no processo: menores de quatorze anos; portadores de enfermidade mental; pessoas em estado de embriaguez ou intoxicadas por substância entorpecente; e pessoas submetidas a medida de segurança detentiva ou a medida de prevenção.
} 
na eventualidade de que o Juiz venha a proferir decisão para a qual não é prevista a intervenção da parte assistida (v.g. aplicação de medida cautelar). ${ }^{342}$

A documentação acima referida é inserida no fascículo do defensor, que é formado e conservado junto ao cartório do GIP. O Ministério Público pode ter vista e extrair cópia desses documentos somente quando for proferida decisão sobre pedido feito por outras partes privadas ou que preveja a intervenção destas. ${ }^{343}$

Após o encerramento da persecução prévia e antes do início da ação penal, o fascículo do defensor é inserido no fascículo único das indagini preliminari. ${ }^{344}$

O defensor pode, a qualquer momento, apresentar ao Ministério Público os elementos materiais provenientes da investigação defensiva, com o objetivo de convencer este órgão a tomar decisão favorável a seu cliente. Neste caso, o resultado da investigação defensiva confluirá para o fascículo do Ministério Público.

\section{- Artigo 391-nonies: atividade de investigação preventiva.}

A investigação defensiva preventiva é aquela que se realiza antes da formal instauração de procedimento criminal, isto é, antes do registro da notícia de crime por parte do Ministério Público. ${ }^{345}$ Com o início das indagini preliminari, tenha ou não o sujeito passivo conhecimento deste fato, a investigação defensiva passa a ser ordinária. ${ }^{346}$

Para desempenhar tal atividade, o defensor deve receber mandato específico em razão da eventualidade de se instaurar procedimento criminal. Tal procuração deve ser expedida com firma autenticada e conter a indicação do defensor e dos fatos aos quais se refere.

\footnotetext{
342 TRIGGIANI, Nicola, Le investigazioni..., pp. 444/47.

${ }^{343}$ Por meio desta limitação do acesso do Ministério Público ao fascículo do defensor, o legislador procurou evitar divulgação prematura dos dados constantes da investigação defensiva. A lei é omissa a respeito da faculdade de as outras partes privadas terem vista do fascículo do defensor, razão pela qual se entende que não há tal possibilidade (VENTURA, Pasquale, Le indagini..., pp. 160/61 e RUGGIERO, Giuseppe, Compendio..., pp. 308/10).

${ }^{344}$ A norma em comento refere-se, equivocadamente, ao artigo 433 do Código de Processo Penal, que versa sobre o fascículo do Ministério Público (VENTURA, Pasquale, Le indagini..., p. 163).

${ }^{345} \mathrm{O}$ tema da investigação defensiva preventiva é examinado, com acuidade, por Pietro Gatto, que destaca a importância desta modalidade investigatória para a busca de fontes de prova favoráveis à defesa do sujeito passivo da investigação preliminar (Le investigazioni..., pp. 41e segs.).

${ }^{346}$ Conforme Pietro Gatto, a distinção entre investigação defensiva preventiva e ordinária deveria ocorrer a partir do instante em que o sujeito passivo tem formal conhecimento da investigação criminal oficial (Ibid., pp. 101/12).
} 
Em sede de investigação defensiva preventiva, o defensor pode praticar todos os atos disciplinados no Código de Processo Penal, exceto aqueles que dependam de autorização ou intervenção do Magistrado, por ainda inexistir procedimento criminal formalmente instaurado. Por isso, é uma forma de investigação mais limitada do que a investigação defensiva ordinária.

- Artigo 391-decies: utilização da documentação da investigação defensiva.

Se o defensor tiver interesse em apresentar ao Magistrado o resultado da investigação defensiva, deve acostá-lo aos autos das indagini preliminari, no prazo máximo de vinte dias após a expedição, pelo Ministério Público, do aviso de conclusão da investigação preliminar referido no artigo 415-bis, 3, do Código de Processo Penal.

Tal documentação é analisada pelo GIP na audiência preliminar e, ao menos em tese, possui o mesmo peso probatório dos elementos trazidos pelo Ministério Público e pela Polícia Judiciária. É o que mencionam Ercole Aprile e Pietro Silvestri, verbis: “Non vi è alcun dubbio che i risultati delle investigazioni difensive, portati direttamente a conoscenza del giudice nella fase delle indagini preliminari, abbiano una efficacia dimostrativa astrattamente parificabile a quella degli atti compiuti dal pubblico ministero e dalla polizia giudiziaria”. 347

O Tribunal de Cassação Penal italiano firmou entendimento no sentido de que os elementos probatórios decorrentes da investigação defensiva são equiparáveis, quanto à utilização e força probatória, aos dados recolhidos na investigação pública. ${ }^{348}$

Uma vez aceita a acusação, os registros dos atos não repetíveis praticados pelo defensor integrarão o fascículo do dibattimento, como determina o artigo 431, 1, “c”, do Código de Processo Penal. Os demais atos, repetíveis em Juízo, são inseridos no fascículo do Ministério Público, regulado no artigo 433 do Código de Processo Penal.

Em caso de exames técnicos não repetíveis, o defensor deve comunicar a sua realização, tempestivamente, ao Ministério Público, para que este órgão participe da

${ }^{347}$ La formazione..., p. 119. Ressalvam os autores que o Juiz, na prática, pode reconhecer diferente força persuasiva entre os dados obtidos na investigação pública e aqueles reunidos na investigação defensiva, pois o defensor, ao contrário do Ministério Público, patrocina interesse privado e não tem o dever de apresentar elementos prejudiciais a seu cliente (Ibid., pp. 120/22). 
perícia, pessoalmente ou por meio de assistente técnico. O Parquet, se discordar da realização da perícia por assistente técnico particular, pode requerer a instauração de incidente probatório. Com relação aos demais atos não repetíveis, o Ministério Público, pessoalmente ou por meio da Polícia Judiciária, tem a faculdade de presenciá-los.

As atas resultantes dessas diligências, caso o Ministério Público participe direta ou indiretamente do ato, são inseridas no fascículo do defensor e no ministerial.

As partes podem usar as declarações fornecidas por testemunhas, durante a investigação defensiva, para contestar os seus depoimentos na fase judicial. Também são válidas as declarações de testemunhas ou do próprio sujeito passivo que, por fatos ou circunstâncias imprevisíveis, não podem ser refeitas judicialmente.

Da análise das normas atinentes à investigação defensiva, nota-se a preocupação do legislador em estabelecer um procedimento em que estivesse bem definido o modo de desenvolvimento da atividade de investigação; as formalidades de documentação dos atos investigatórios e de formação do fascículo do defensor; e a utilização processual dos elementos obtidos.

No entanto, a lei que regulamentou a investigação defensiva não cuidou de pontos relevantes para a aplicação prática desse instituto. Nem poderia ser diferente, pois, além do ineditismo e da complexidade da matéria, era impossível para o legislador prever todas as implicações decorrentes da incorporação da investigação defensiva ao ordenamento jurídico italiano.

Por conta disso, desde a entrada em vigor do aludido diploma legal, em janeiro de 2001, surgiram inúmeras questões entre os juristas italianos a respeito da investigação defensiva, que merecem ser abordadas para melhor compreensão do tema.

\section{V.2.4. Principais temas discutidos na Itália acerca da investigação criminal defensiva}

O primeiro e um das mais importantes pontos levantado pela doutrina italiana diz respeito aos limites da atividade investigatória do defensor. Este, por ser antagonista da

${ }^{348}$ Conferir julgados citados em STEFANI, Eraldo, Codice..., pp. 294/95. Ver, também, TRIGGIANI, 
acusação na relação dialética processual e patrocinar interesse privado, não tem o dever de recolher elementos de prova desfavoráveis ao próprio assistido. Já o Ministério Público e a Polícia Judiciária, por perseguirem o interesse público de realização da Justiça, devem investigar todos os fatos relacionados à suposta prática ilícita, inclusive os favoráveis ao sujeito passivo, conforme disposto no artigo 358 do Código de Processo Penal.

O defensor investiga, documenta e apresenta ao Juiz, apenas os dados relevantes para a defesa dos interesses de seu cliente, sem o dever de buscar a verdade ou mesmo de denunciar crime do qual tenha conhecimento no exercício da atividade investigatória (artigo 334-bis do Código de Processo Penal). ${ }^{349}$

No entanto, o defensor não pode introduzir no processo provas sabidamente falsas ou obtidas de maneira ilícita, nem destruir provas, sob pena de ser incriminado pelo delito de favorecimento pessoal (artigo 378 do Código Penal). ${ }^{350}$

Por conta desta diferente atuação investigatória entre os órgãos públicos e o defensor, o legislador concedeu poderes coercitivos apenas aos primeiros. O defensor, ao efetuar investigação privada, deve contar com o assentimento do titular do direito para obter as informações desejadas ou, se não houver colaboração deste, recorrer à Autoridade Judiciária ou ao Ministério Público, conforme o caso.

Assinala Paolo Tonini que “o Ministério Público e a polícia judiciária têm poderes coercitivos sobre coisas e, assim, podem determinar a realização de buscas, apreensões e inspeções probatórias com base no fato de que existem indícios da prática de um crime. Os sujeitos passivos dos poderes do Ministério Público podem ser tanto o investigado como um terceiro não acusado (por exemplo, o detentor de um objeto que deve ser apreendido). Diferentes são os poderes da vítima e do investigado. Os defensores destes, quando realizam investigações particulares, não têm poderes coercitivos e, por isso, podem colher informações na medida em que o titular do direito o consinta. Em caso de dissenso, o defensor pode somente fazer requerimentos à autoridade judiciária”. 351

Nicola, Le investigazioni..., pp. 535/41.

349 APRILE, Ercole e SILVESTRI, Pietro, La formazione..., pp. 33/34 e ROSSI, Gianluca. "Indagini difensive: luci ed ombre della norma vigente”, p. 01. Disponível na internet: “www.giuffrereggioemilia.it/main/indaginidifensive”. Acesso em 25 de outubro de 2008.

350 Tal vedação consta do artigo 14, I, do Código Deontológico Forense.

351 “Direito de defesa e prova científica: novas tendências do processo penal italiano”..., p. 207. Vide, também, do mesmo autor: Manuale..., pp. 496/97. 
A ausência de poder de polícia do defensor, no exercício da investigação defensiva, restringe sobremaneira a eficácia da atividade investigatória e afeta a paridade de armas entre o Ministério Público e a defesa. Como solução, defende-se a instituição de poder de polícia para o defensor, dentro de limites bem determinados, principalmente para colher o depoimento de testemunhas. ${ }^{352}$

Em segundo lugar, a doutrina italiana diverge sobre a qualificação subjetiva, pública ou privada, do advogado que documenta a investigação defensiva e as conseqüências que podem advir do registro infiel desses atos. ${ }^{353}$

A Unione delle Camere Penali, em sessões ocorridas entre os meses de junho e setembro de 2006, proferiu decisão no sentido de que a referida atividade de documentação teria a característica de função pública, por ser expressão de um poder de certificação e configurar exercício de atividade pública. Por conseguinte, a utilização processual de uma ata elaborada irregularmente configuraria o crime de falsidade ideológica, previsto no artigo 479 do Código Penal. ${ }^{354}$

Na mesma linha, foi proferida a sentença n. ${ }^{\circ}$ 510/03, elaborada pelo Juiz De Marchi, do Tribunal de Torino. De acordo com esta decisão, o defensor, no momento que registra formalmente a investigação defensiva, assume a qualidade de oficial público, que redige atos públicos. Por conseguinte, a elaboração deturpada destes atos caracterizaria o delito de falsidade ideológica.

Por outro lado, alguns juristas defendem que a documentação dos atos de investigação defensiva não teria caráter público, pois lhe faltaria o aspecto de obrigatoriedade inerente à função pública. Vale dizer: o defensor opta por documentar os

\footnotetext{
${ }^{352}$ NOCETTI, Alessandro, “Indagini difensive, parità sostanziale o finzione normativa?”..., p. 02.

${ }^{353}$ A respeito dessa matéria, conferir TONINI, Paolo, Manuale..., pp. 506/07 e STEFANI, Eraldo, Codice..., pp. 297/98.

${ }^{354}$ Umberto Guerini posicionou-se favoravelmente a este entendimento. Segundo o autor, a atividade de documentação dos atos de investigação defensiva teria finalidade pública, qual seja, o uso em procedimento criminal para formar o convencimento da Autoridade Judiciária. Por conta disso, tal atividade teria natureza pública e não privada, o que justificaria até mesmo a sua equiparação probatória com os atos investigatórios realizados pelo Ministério Público ("Sulla qualifica soggettiva dell’avocato che svolge indagini difensive", pp. 03/05. Disponível na internet: "www.dirittoegiustiziaonline.it/penale". Acesso em 22 de setembro de 2008).
} 
atos da investigação defensiva apenas se beneficiar o seu cliente e for conveniente para a sua estratégia processual. ${ }^{355}$

Para esta corrente, a documentação da investigação defensiva constituiria serviço privado de necessidade pública, para o qual se prevê poder de certificação. O exercício irregular desta atividade configuraria delito específico, tipificado no artigo 481 do Código Penal, cuja sanção é inferior ao crime de falsidade ideológica.

Em terceiro lugar, aborda-se a relação da investigação defensiva com a legislação referente à proteção dos dados pessoais. ${ }^{356}$ Esta regulamentação legal incide sobre a investigação defensiva em dois aspectos: (i) no âmbito interno, a atividade investigatória deve se desenvolver de modo a garantir o sigilo dos dados recolhidos; (ii) no âmbito externo, a investigação defensiva deve respeitar a privacidade de terceiros.

No tocante à questão da privacidade, Paolo Tonini ${ }^{357}$ menciona a importância de distinguir investigação defensiva sobre “dados não sensíveis” e sobre “dados sensíveis” (estes últimos dizem respeito à origem racial, convicções religiosas, filosóficas ou políticas, estado de saúde e vida sexual). No primeiro caso, não é necessário o consentimento do interessado e nem mesmo prévia comunicação sobre os dados a serem examinados. Já, no segundo, a investigação defensiva também é possível, mas com maiores limitações.

De fato, o tratamento de dados sensíveis pelo defensor somente pode ocorrer mediante prévia autorização do garante, isto é, do sujeito responsável pela proteção destas informações. Além disso, devem ser atendidas as seguintes condições: indispensabilidade do acesso aos dados para a execução de atividades profissionais específicas requeridas pelo assistido, com finalidade determinada e legítima; e impossibilidade de o encargo profissional ser desenvolvido a partir do exame de dados anônimos ou de dados pessoais de natureza diversa.

\footnotetext{
${ }^{355}$ APRILE, Ercole e SILVESTRI, Pietro, Le indagini..., pp. 524/27; ROSSI, Gianluca, “Indagini difensive: luci ed ombre della norma vigente”..., p. 03 e VENTURA, Pasquale, Le indagini..., pp. 199/209.

${ }^{356}$ Lei n. ${ }^{\circ}$ 675, de 31 de dezembro de 1996, posteriormente convertida no Decreto Legislativo n. ${ }^{\circ} 196$, de 30 de junho de 2003, denominado “Código em matéria de proteção de dados pessoais”. Existe, ainda, estatuto legal específico referente ao tratamento de dados sensíveis por parte dos investigadores privados autorizados (Autorização n. ${ }^{\circ}$ 06, de 24 de agosto de 2007).

357 TONINI, Paolo, Manuale..., pp. 521/24. Conferir, também, APRILE, Ercole e SILVESTRI, Pietro, La formazione..., pp. 26/29 e TRIGGIANI, Nicola, Le investigazioni..., pp. 386/404.
} 
Em ambas as situações, as informações devem servir apenas para o escopo da investigação defensiva ou para a tutela judiciária de um direito, por período estritamente necessário à consecução desses propósitos. Os dados pessoais obtidos com violação à disciplina legal não podem ser utilizados, como prescrito no artigo 11 do Decreto Legislativo n. ${ }^{\circ}$ 196/2003. ${ }^{358}$

Outro ponto analisado é o momento em que o sujeito passivo deve ser comunicado da existência do procedimento criminal, para que possa executar a investigação defensiva.

Atualmente, a doutrina italiana vem se posicionando no sentido de que tal aviso deve ocorrer tão logo seja instaurado o procedimento criminal, com o registro da notícia de crime pelo Ministério Público, e não mais com a informazione di garanzia, expedida apenas no momento em que se efetua um ato para o qual se exige a presença de defensor. $^{359}$

Discute-se, por fim, a possibilidade de o defensor e seus auxiliares efetuarem atos atípicos de investigação defensiva, isto é, que não estão expressamente previstos e disciplinados em lei, como, por exemplo, o reconhecimento pessoal e fotográfico e a acareação. $^{360}$

Em regra, admite-se a realização de atos investigatórios atípicos, por encontrarem respaldo nos princípios da igualdade e da ampla defesa e no direito à prova. A única restrição é que sejam praticados de forma lícita.

\footnotetext{
${ }^{358}$ In verbis: "I dati personali trattati in violazione della disciplina rilevante in materia di trattamento dei dati personali non possono essere utilizzati”.

${ }^{359}$ GATTO, Pietro, Le investigazioni..., pp. 89/100; APRILE, Ercole e SILVESTRI, Pietro, La formazione..., p. 156 e TRIGGIANI, Nicola, Le investigazioni..., pp. 196/204.

${ }^{360}$ TONINI, Paolo, Manuale..., p. 500; VENTURA, Pasquale, Le indagini..., pp. 103/04 e TRIGGIANI, Nicola, Le investigazioni..., pp. 215/23.
} 


\section{A CONCRETIZAÇÃO DA INVESTIGAÇÃO CRIMINAL DEFENSIVA SOB A ÓTICA DA EFICIÊNCIA E DO GARANTISMO}

\section{VI.1. O significado de eficiência e garantismo para o processo penal}

Com base nos conceitos antes analisados e, particularmente, na experiência italiana, vale tentar traçar um esboço de procedimento ideal de investigação defensiva, isto é, como deveria ser regulada a atividade investigatória do defensor de forma a atender aos pressupostos da eficiência e do garantismo, norteadores deste trabalho.

A princípio, importa definir eficiência e garantismo, no campo processual penal, para, em seguida, verificar os aspectos procedimentais da investigação defensiva à luz destes pressupostos.

O termo “eficiência” possui sentido diverso dos vocábulos “eficácia” e “efetividade”. Por eficiência entende-se a capacidade de uma ação de produzir determinado efeito, sendo medida pela maior ou menor qualidade do meio para alcançar o resultado. A eficácia diz respeito à qualidade do resultado em si, ou seja, leva em consideração o tipo de resultado atingido. Por seu turno, a efetividade também se refere aos efeitos alcançados, relacionando-os a certos objetivos almejados. ${ }^{361}$

Transpondo essas noções para o processo penal, leciona Antonio Scarance Fernandes ${ }^{362}$ que eficiência é a capacidade de um ato processual ou de investigação de gerar o efeito que dele se espera; enquanto eficaz é o ato que produz o efeito esperado e, por fim, a análise da efetividade implica verificação do resultado positivo do ato realizado.

O garantismo, por sua vez, está ligado à idéia de devido processo legal, sob a ótica subjetiva e objetiva, ou seja, como garantia das partes, essencialmente do acusado, e como garantia do justo processo, respectivamente. ${ }^{363}$

\footnotetext{
361 SCARANCE FERNANDES, Antonio. "Reflexões sobre as noções de eficiência e de garantismo no Processo Penal” in Sigilo no Processo Penal: eficiência e garantismo. SCARANCE FERNANDES, Antonio; ALMEIDA, José Raul Gavião de e MORAES, Maurício Zanoide de (orgs.). São Paulo: Revista dos Tribunais, 2008, p. 21.

${ }^{362}$ Ibid., pp. 24/26.

363 SCARANCE FERNANDES, Antonio, Teoria Geral..., p. 40. A antítese do garantismo é o utilitarismo processual, que prega o combate à criminalidade por meio de um processo penal mais célere, no qual haveria uma redução dos direitos e garantias individuais em prol do interesse estatal de apurar e apenar condutas mais rapidamente (LOPES Jr., Aury, Sistemas..., p. 23).
} 
Na consagrada obra “Direito e Razão - Teoria do Garantismo Penal”, Luigi Ferrajoli $^{364}$ construiu um modelo ideal garantista, composto por dez axiomas deontológicos, que seriam condições indispensáveis para a afirmação da responsabilidade penal e aplicação da pena, a saber: (i) princípio da retributividade da pena em relação ao delito; (ii) princípio da legalidade; (iii) princípio da necessidade ou da economia do Direito Penal; (iv) princípio da lesividade do evento; (v) princípio da materialidade da ação; (vi) princípio da culpabilidade ou da responsabilidade pessoal; (vii) princípio da jurisdicionariedade; (viii) princípio acusatório ou da separação entre Juiz e acusação; (ix) princípio do ônus da prova; (x) princípio do contraditório ou da defesa.

Apenas um sistema jurídico que contemplasse todos os requisitos mencionados seria perfeitamente garantista. Todavia, como ressaltado pelo próprio autor, trata-se de "um modelo-limite, apenas tendencialmente e jamais perfeitamente satisfatível”. 365

Diante disso, os doutrinadores do processo penal começaram a trabalhar com as noções de eficiência e garantismo, com o intuito de alcançar um processo equilibrado, que, a um só tempo, satisfizesse os anseios sociais por segurança (reprimindo a conduta comprovadamente criminosa) e o direito individual à liberdade (garantindo ao acusado meios para se defender e afastar imputações injustas).

A conciliação de eficiência e garantismo, no processo penal, é fundamental “para que se evite tanto o uso cego do poder (eficácia exacerbada do sistema) como a queda em inócuo ritualismo sem qualquer punição justa (uso exacerbado do garantismo)". 366

Em síntese, o binômio eficiência e garantismo, no processo penal, traduz-se na necessidade de se balancear adequadamente os direitos fundamentais à liberdade e à segurança. Desse modo, a persecução penal será eficiente e garantista, se atingir, em prazo razoável, um resultado justo, consistente na atuação do direito punitivo, com a observância dos meios essenciais para a defesa da liberdade do acusado. ${ }^{367}$

\footnotetext{
${ }^{364}$ Direito e razão..., pp. 74/75.

${ }^{365}$ Ibid., p. 74.

${ }^{366}$ DEZEM, Guilherme Madeira, Da prova penal..., p. 73

${ }^{367}$ SCARANCE FERNANDES, Antonio, Teoria Geral..., p. 40.
} 
Conforme demonstrado nesta dissertação, a investigação defensiva está claramente em harmonia com esta idéia de eficiência e garantismo. Primeiro, porque ela coloca o imputado em igualdade de condições com a acusação, permitindo-lhe recolher, por meio de seu defensor, elementos de prova de descargo. Segundo, porque ela aumenta o campo cognitivo do Magistrado, que, ao decidir sobre a viabilidade da ação penal ou alguma medida cautelar no curso da investigação preliminar, poderá cotejar os dados resultantes da investigação pública e da defensiva.

Sendo assim, a investigação defensiva reforça garantias fundamentais do imputado e minora o risco de ações penais infundadas, que levariam à movimentação desnecessária e custosa do aparato judiciário estatal, tornando a Justiça penal mais eficiente.

\section{VI.2. O modo de execução da investigação criminal defensiva}

A investigação defensiva é instrumento a serviço do defensor do imputado, que lhe permite, desde o início da persecução prévia ou mesmo na eventualidade de sua instauração, recolher dados materiais úteis à defesa dos interesses de seu cliente.

Francisco da Costa Oliveira ${ }^{368}$ cita alguns objetivos da investigação defensiva: (i) comprovação do álibi ou de outras razões demonstrativas da inocência do imputado; (ii) desresponsabilização do imputado em virtude da ação de terceiros; (iii) exploração de fatos que revelam a ocorrência de causas excludentes de ilicitude ou de culpabilidade; (iv) eliminação de possíveis erros de raciocínio a que possam induzir determinados fatos; (v) revelação da vulnerabilidade técnica ou material de determinadas diligências realizadas na investigação pública; (vi) exame do local e a reconstituição do crime para demonstrar a impropriedade das teses acusatórias; (vii) identificação e localização de possíveis peritos e testemunhas.

Tendo em vista a finalidade da investigação defensiva, é evidente que a sua eficácia está diretamente ligada ao fator tempo. Quanto antes começar a atividade

${ }^{368}$ OLIVEIRA, Francisco da Costa, A Defesa..., p. 58. 
investigatória do defensor, maior a probabilidade de se obter elementos materiais relevantes para a defesa do imputado.

Normalmente, a investigação defensiva ocorre após o imputado tomar conhecimento de procedimento criminal voltado contra si. É que tal atividade depende da nomeação de defensor pelo imputado, o que costuma acontecer somente após a ciência da persecução penal.

Por isso, o imputado deve ser comunicado da existência do procedimento criminal com a maior antecedência possível, para que possa providenciar defensor, privado ou público, o qual verificará a necessidade de efetuar atos investigatórios.

Na Itália, tal aviso é feito por meio da informazione di garanzia, encaminhada pelo Ministério Público ao sujeito passivo da investigação preliminar, antes de se realizar ato que exija a presença de defensor.

Melhor seria se o imputado fosse comunicado da própria instauração da investigação pública, salvo hipóteses excepcionais de sigilo, e desde então lhe fosse assegurado o direito à investigação defensiva, em qualquer estado e grau da persecução criminal, conforme a estratégia de defesa adotada por seu defensor.

A par disso, a investigação defensiva pode ser necessária mesmo se não houver procedimento criminal formalmente instaurado, ou seja, quando alguém suspeita de que pode ser criminalmente investigado. ${ }^{369}$ É o que se denomina investigação defensiva preventiva, que deve ser admitida, mas com as devidas limitações. Nesta modalidade, o defensor não pode executar medidas que dependam de intervenção da Autoridade Judiciária, justamente por inexistir investigação pública.

Durante a investigação defensiva, o defensor deve possuir poderes investigatórios equivalentes aos dos órgãos públicos, por força do princípio da paridade de armas e do direito de defesa.

Também devem incidir sobre a investigação defensiva os mesmos limites da investigação pública, principalmente no que diz respeito à necessidade de prévia 
autorização judicial para a adoção de medidas restritivas de direitos fundamentais. A investigação defensiva possui, ainda, restrição adicional decorrente da ausência de poder de polícia, atribuído exclusivamente aos órgãos públicos, como se examinará adiante. Por tal motivo, o defensor depende do consentimento do titular do direito para a prática de ato investigatório.

Dessarte, no âmbito da investigação defensiva, deve ser permitido ao defensor a prática de qualquer atividade investigatória típica ou atípica, desde que não viole preceitos constitucionais e legais e exista a concordância do titular do direito.

O exemplo mais comum de ato típico de investigação é a inquirição de pessoas capazes de auxiliar na elucidação dos fatos, sejam meras testemunhas ou pessoas envolvidas no mesmo procedimento criminal. Não há dúvida de que estas oitivas podem fornecer subsídios importantes para o defensor e, muitas vezes, são os primeiros passos para o desenvolvimento do trabalho de investigação.

Por tal motivo, defende-se a existência do dever da testemunha de responder às perguntas formuladas e de dizer a verdade, sob pena de ser criminalmente responsabilizada. Aliás, tal tese vem sendo firmemente sustentada pelos doutrinadores italianos, com a finalidade de alterar a legislação daquele país, onde a testemunha pode fazer uso da faculdade de não responder às indagações.

O co-investigado, por sua vez, não tem o dever de depor, pois está amparado pelo direito de defesa, que possui como corolários o direito a não se auto-incriminar e o direito ao silêncio. Além disso, é indispensável que a entrevista do co-investigado ocorra na presença de seu patrono.

Também deve ser facultado ao defensor examinar documentos e deles extrair cópia, por meio de requisição a particulares ou a órgãos públicos, bem como acessar lugares públicos ou privados, neste último caso mediante prévia autorização judicial, para realizar vistorias, exames técnicos ou obter dados.

369 Tais suspeitas podem advir, por exemplo, de uma fiscalização administrativa que costuma gerar procedimentos criminais (v.g., crimes contra a ordem tributária, crimes previdenciários, crimes ambientais etc.). 
Muitas vezes o defensor não tem conhecimento técnico específico para a realização de determinado ato investigatório. Neste caso, deve poder nomear assistente técnico para a execução de perícias e confecção dos respectivos laudos.

Importante distinguir, no contexto investigatório, a prática de atos repetíveis e não repetíveis. Com relação aos primeiros, não há qualquer restrição para a atividade investigatória do defensor, uma vez que podem ser refeitos na fase judicial.

Já os atos irrepetíveis, a nosso ver, não podem ser objeto de investigação defensiva, pois devem ser efetuados sob contraditório. Nesta hipótese, cabe a instalação de incidente probatório, nos próprios autos da investigação pública, para a produção do ato. $\mathrm{O}$ resultado deste incidente, necessariamente, integra os autos do procedimento criminal.

A solução aventada pelo legislador italiano, que permitiu a realização de atos não repetíveis pelo defensor, mediante prévio aviso do órgão ministerial, não parece ser a mais consentânea com as garantias do devido processo legal.

Os atos de investigação defensiva são registrados pelo defensor, em regra, na forma escrita. Para evitar questionamentos acerca da confiabilidade destes elementos, deve haver regulamentação clara do seu modo de documentação, sob pena de inutilização processual.

No momento considerado oportuno e se julgar conveniente, de acordo com a sua estratégia processual, o defensor pode revelar o resultado da investigação defensiva à Autoridade Judiciária.

Com efeito, a defesa, por meio de sua investigação privada, procura, de um lado, afastar as imputações trazidas pela acusação e, de outro, comprovar as suas proposições, pelo menos até o ponto em que a dúvida penda a seu favor. ${ }^{370}$ Portanto, o defensor introduzirá os elementos defensivos nos autos do procedimento criminal conforme o seu propósito na persecução penal (se pretende o arquivamento do feito, ainda na fase preliminar; se pretende a absolvição do acusado em julgamento de mérito; se pretende evitar alguma medida coercitiva, física ou patrimonial; ou ainda se pretende apenas restringir o objeto da imputação).

${ }^{370}$ OLIVEIRA, Francisco da Costa, A Defesa..., p. 166. 
A apresentação do resultado da investigação defensiva costuma ocorrer durante a persecução prévia, com o objetivo de evitar a instauração de ação penal. Neste caso, forma-se o fascículo do defensor, mantido junto ao ofício judicial, sob sigilo, até a conclusão da instrução preliminar. Com o término desta fase, o referido fascículo deve ser apensado aos autos da investigação pública.

A acusação e as partes privadas podem ter acesso ao fascículo do defensor, para exercício do contraditório, somente na fase em que se examina a viabilidade da acusação ou antes de ser proferida alguma decisão que exija a sua participação.

Se o defensor apresentar a documentação referente à investigação defensiva apenas na fase processual, o Juiz deve verificar a possibilidade de sua introdução aos autos da ação penal, submetendo o material defensivo ao contraditório.

Saliente-se, por fim, que os elementos defensivos costumam ingressar nos autos da persecução penal sob a forma documental e, se forem utilizados em juízo, terão a natureza jurídica de prova documental.

\section{VI.3. Os limites jurídicos da investigação criminal defensiva}

Para se compreender os limites jurídicos da investigação defensiva, ${ }^{371}$ é preciso ter em mente a seguinte premissa: o defensor patrocina interesse privado, consistente na defesa do direito à liberdade de seu cliente. Ainda que seja função de elevado interesse público, essencial à administração da Justiça, é incontestável o seu caráter privado.

Por conta disso, a investigação defensiva não tem por escopo alcançar a verdade e nem precisa apurar todo e qualquer fato relevante, sendo direcionada exclusivamente ao levantamento de informações favoráveis ao imputado. Por conseguinte, o defensor não está adstrito a apresentar à Autoridade Judiciária os elementos obtidos em

\footnotetext{
${ }^{371}$ Os limites jurídicos são aqueles inferidos do ordenamento jurídico. Existem, ainda, limites materiais à investigação defensiva, relacionados à falta de recursos técnicos e humanos do defensor para a prática de determinados atos investigatórios, que não são objeto deste estudo.
} 
sua atividade investigatória e nem mesmo a denunciar crime do qual tenha conhecimento no exercício desta função.

De outra parte, a investigação pública, ao menos em tese, pauta-se pelo interesse público de realização da Justiça e deve elucidar os fatos constantes da notícia de crime, averiguando todas as circunstâncias relacionadas à prática delitiva, inclusive as favoráveis ao imputado.

Em virtude desta diferença de interesses tutelados pela investigação pública e pela investigação defensiva, reconhece-se poder de polícia apenas à primeira. Vale dizer, o defensor, no exercício de sua investigação, não tem poder coercitivo para compelir terceiros a fornecerem informações e documentos. Se não houver colaboração por parte do titular do direito, o defensor deve se valer do Poder Judiciário.

A total falta de poder de polícia é um óbice considerável para o desempenho da investigação defensiva e tem o condão de torná-la praticamente inócua. Conforme vem propugnando juristas italianos, deve ser conferido poder de polícia ao defensor, com base em parâmetros legais claros, para a realização de certos atos investigatórios.

Em alguns casos, como a oitiva de testemunhas e a obtenção de documentos em poder da Administração Pública ou de particulares, nada justifica o tratamento desigual entre o defensor e os órgãos públicos encarregados da investigação, com a atribuição de poder de polícia apenas a estes últimos. Para coibir eventuais abusos na atuação do defensor, bastaria estipular ônus semelhantes aos já existentes para as autoridades públicas.

Evidente que este poder de polícia não é pleno. Assim como ocorre na investigação pública, o defensor depende de prévia autorização judicial para a execução de medidas que importem restrição a direitos fundamentais.

Outra limitação imposta à investigação defensiva refere-se à forma de obtenção dos elementos de convicção pelo defensor. Processualmente, são inadmissíveis e inválidas as provas sabidamente falsas ou obtidas de modo ilícito.

No âmbito do Direito material, a atividade probatória defensiva não pode obstruir a investigação pública e nem danificar fontes de prova, sob pena de configurar ilícito penal. Assim, se houver colidência entre as atividades investigatórias realizadas pelo 
defensor e pelos órgãos públicos, prevalecem, em regra, estas últimas. Tal situação deve ser expressamente regulada em lei, com disposições claras a respeito do seu conteúdo e duração.

Ainda como restrição à investigação defensiva, vale mencionar a questão da privacidade de terceiros cujos dados são objeto da investigação. O defensor deve evitar a divulgação indevida destes dados, empregando-os estritamente para os fins da investigação e dentro do espaço de tempo necessário para alcançar o seu desiderato. Por outro lado, o acesso a alguns dados, considerados sigilosos, depende de prévia autorização judicial. O desrespeito a tais regras deve acarretar a inutilização processual dos dados.

\section{VI.4. A valoração do resultado da investigação criminal defensiva}

Alerta Antonio Scarance Fernandes que “não há, no direito processual penal brasileiro, regra a respeito da investigação pela defesa. Nada impede a sua realização, mas, além de o investigado não poder contar com a colaboração da polícia, eventuais elementos obtidos pela defesa são vistos com muita desconfiança pelos promotores e juízes e, em regra, pouco considerados", 372

O autor chama a atenção para um dos principais problemas enfrentados pela investigação defensiva: a diferença de valor probatório dos elementos materiais obtidos pelo defensor e pelos órgãos públicos.

A secular tradição de investigações inquisitoriais gerou injusta presunção de credibilidade para os dados colhidos pelos órgãos públicos; enquanto os informes reunidos pela defesa, seja em procedimento próprio ou mesmo nos autos da investigação pública, são vistos com muita reserva.

${ }^{372}$ Teoria Geral..., p. 99. 
Isso porque, como destacado por Francisco da Costa Oliveira, ${ }^{373}$ a investigação defensiva, às vezes, é interpretada não como meio de investigação, mas como instrumento para encobrir o crime e eliminar provas, obstruindo a realização da Justiça penal.

Tal questão, como se viu, vem sendo intensamente debatida na Itália, onde a doutrina e a jurisprudência pacificaram entendimento no sentido de que o resultado da investigação defensiva é equivalente ao da investigação pública, com relação à força probatória e à utilização processual.

A esse respeito, afirma Pasquale Ventura que "gli elementi raccolti dal difensore e documentati ai sensi degli artt. 391-ter e 391-sexies c.p.p. hanno la stessa valenza probatoria di quelli raccolti dal pubblico ministero e dalla polizia giudiziaria; essi, una volta presentati al pubblico ministero a norma dell'art. 391-octies comma 4 c.p.p. o inseriti nel fascicolo del difensore, sono utilizzabili per ogni decisione che il giudice adotti nel corso delle indagini preliminari”. ${ }^{374}$

Não obstante, a doutrina italiana ressalva que, devido ao princípio do livre convencimento das provas, o Juiz, no seu íntimo, pode ver com descrédito os elementos recolhidos pelo defensor.

Ora, é impossível as partes avaliarem a convicção subjetiva do Magistrado. O que elas podem e devem examinar - e, se for o caso, impugnar - é a exteriorização desta convicção, que se manifesta por meio da motivação da decisão. Dessa feita, cabe ao defensor analisar a decisão judicial e verificar se o Magistrado sopesou, de forma equânime, os dados aportados pela defesa e pela acusação.

Além disso, para garantir o mesmo grau de confiabilidade entre a investigação defensiva e a investigação pública, o legislador deve regular adequadamente os atos investigatórios do defensor, prescrevendo, no mínimo, os mesmos requisitos impostos aos órgãos públicos.

Assim, para retirar toda carga de preconceito sobre a investigação defensiva e lhe atribuir o mesmo peso da investigação pública, deve haver previsão legal de procedimento para a realização da investigação defensiva, no qual se defina, com base em

${ }^{373}$ A Defesa..., p. 33.

${ }^{374}$ Le indagini..., p. 164. 
critérios constitucionais e legais, a forma de execução e documentação dos atos investigatórios pelo defensor, punindo o seu exercício irregular ou abusivo.

\section{VI.5. A inserção da investigação criminal defensiva no Direito brasileiro}

A partir do estudo dos aspectos substanciais e procedimentais relacionados à investigação defensiva, sugere-se de lege ferenda a incorporação deste instituto ao processo penal brasileiro.

Como se viu, a investigação defensiva decorre do princípio da isonomia e do direito de defesa, inerentes ao sistema jurídico acusatório, pois permite ao imputado, em igualdade de condições com a acusação, buscar elementos de prova de descargo.

A princípio, a investigação defensiva seria imprescindível apenas nos ordenamentos que prevêem o Ministério Público como responsável pela investigação criminal. É que este órgão, enquanto parte acusatória na persecução penal, direciona a investigação pública no sentido de demonstrar as suas teses, olvidando dos interesses do imputado. Logo, o imputado deve também poder investigar para sustentar materialmente os seus argumentos.

Todavia, a investigação defensiva pode ser necessária mesmo na hipótese de a investigação pública ser efetuada por órgão diverso do Parquet, como ocorre no ordenamento jurídico brasileiro.

Com efeito, no Brasil, a investigação criminal está a cargo da Polícia Judiciária, sob a fiscalização do Ministério Público e do Juiz. Em que pese o vigoroso movimento em prol da investigação ministerial, tal pretensão não encontra respaldo no atual texto constitucional.

O inquérito policial deveria ser instrumento para a isenta apuração dos fatos relatados na notícia de crime, pois é dirigido pela Polícia Judiciária, órgão pretensamente imparcial e desvinculado das pretensões de ambas as partes na persecução penal. 
No entanto, não é o que se constata na prática. O inquérito policial é muito mais voltado à formação do acervo probatório da acusação do que da defesa. Isso ocorre, essencialmente, por dois motivos: (i) desequilíbrio de poderes entre Ministério Público e imputado, nesta fase, com claro favorecimento ao primeiro; e (ii) preconceito arraigado na Polícia Judiciária e no Ministério Público de que a eficácia da investigação está ligada à comprovação do crime.

Por conta deste perfil acusatório do inquérito policial, a legislação processual penal pátria deve instituir e regulamentar a investigação defensiva, como faculdade a ser exercida pelo defensor do imputado, dentro de parâmetros bem definidos, para reunir dados úteis às teses defensivas.

Com isso, assegura-se a indispensável paridade de armas entre as partes e, ainda, amplia-se o campo cognitivo do Magistrado, na fase preliminar, evitando acusações infundadas ou medidas cautelares descabidas.

A respeito dos benefícios da investigação defensiva, observam André Boiani Azevedo e Edson Luís Baldan, citando Franco e Paola Scorza, que “as vantagens da investigação a cargo do defensor são inegáveis e interessam ao panorama processual penal em geral, 'seja porque permite à defesa preparar-se adequadamente e sustentar a própria tese, seja porque contribui a garantir o direito à prova em qualquer estado e grau do procedimento, seja, enfim, porque se volta a realizar cabalmente o princípio de paridade que, como já dito, constitui uma das pilastras sobre a qual se funda a reforma do justo processo'”. 375

Há quem entenda que a investigação defensiva, apesar de concebível no plano teórico, seria impraticável no Brasil, em virtude da precária situação econômica da maioria

\footnotetext{
375 “A preservação do devido processo legal pela investigação defensiva (ou do direito de defender-se provando)”... , p. 07. Estes autores enumeram uma série de conseqüências favoráveis resultantes da investigação defensiva, dentre as quais se destacam: (i) aprimoramento da investigação policial como contraponto eficaz às provas produzidas pelo defensor; (ii) redimensionamento do papel do advogado dentro e fora do processo, que deixará de ser mero espectador e assumirá postura ativa na formação da prova criminal; (iii) obrigação de motivação judicial na admissão da acusação, o que evitaria a instauração de ações penais infundadas; e (iv) maior proximidade do processo penal com a verdade, em razão do fortalecimento da prova criminal, o que, por conseqüência, garantiria maior segurança ao Magistrado para proferir decisão, pois se basearia nas provas produzidas por ambas as partes em atenção ao princípio da isonomia (Ibid., p. 08).
} 
dos imputados, que não podem custear defensor particular. ${ }^{376}$ Entretanto, neste caso, cabe ao Estado suprir a deficiência econômica do imputado, tal como ocorre na fase processual.

De fato, o imputado tem o direito fundamental de defesa, do qual se extraem os direitos à prova e à investigação. O direito de defesa é essencial para garantir a regularidade da própria persecução penal. Por isso, deve ser garantido o seu efetivo exercício por meio de defensor técnico.

Se o imputado não tiver condições de suportar os custos de um advogado, incumbe ao Estado prover assistência jurídica integral e gratuita, nos termos do referido artigo 5º LXXIV, da Constituição da República, e do artigo 8º 2, “e”, da Convenção Americana sobre Direitos Humanos. ${ }^{377}$

Nessa linha, cabe à Defensoria Pública patrocinar os interesses dos hipossuficientes, nos termos do artigo 134 da Constituição da República, verbis: “a Defensoria Pública é instituição essencial à função jurisdicional do Estado, incumbindo-lhe a orientação jurídica e a defesa, em todos os graus, dos necessitados, na forma do art. $5^{\circ}$, LXXIV”.

Para Rogério Lauria Tucci, a Defensoria Pública é instituição tipicamente social, de “advocacia do povo”, que servirá para “a necessária e prévia orientação jurídica, bem como para a defesa, pré-processual e processual, em todos os graus de jurisdição, das pessoas desprovidas de recursos financeiros para o respectivo custeio”. ${ }^{378}$

Desde a promulgação da Carta Constitucional de 1988, aguardava-se a elaboração de lei específica sobre a Defensoria Pública, para efetivar os postulados constitucionais da igualdade e da ampla defesa - o que só veio a ocorrer em 12 de janeiro de 1994, com a promulgação da Lei Complementar n. ${ }^{\circ}$ 80, que instituiu a Defensoria Pública da União.

Consoante o artigo $4^{\circ}$ do aludido diploma legal são funções deste órgão: (i) “atuar junto aos estabelecimentos policiais e penitenciários, visando assegurar à pessoa,

\footnotetext{
${ }^{376}$ LOPES Jr., Aury, Sistemas..., p. 96.

${ }^{377}$ Dispõe a norma da Convenção internacional que o acusado tem o "direito irrenunciável de ser assistido por um defensor proporcionado pelo Estado, remunerado ou não, segundo a legislação interna, se o acusado não se defender ele próprio nem nomear defensor dentro do prazo estabelecido pela lei”.

378 TUCCI, Rogério Lauria, Direitos e garantias..., p. 104.
} 
sob quaisquer circunstâncias, o exercício dos direitos e garantias individuais” (inciso VIII); e (ii) "assegurar aos seus assistidos, em processo judicial ou administrativo, e aos acusados em geral, o contraditório e a ampla defesa, com recursos e meios a ela inerentes” (inciso IX).

No Estado de São Paulo, a Defensoria Pública foi criada apenas em 09 de janeiro de 2006, por meio da Lei Complementar n. ${ }^{\circ}$ 988, que conferiu atribuições semelhantes àquelas previstas na lei federal. ${ }^{379}$

Sendo assim, a dificuldade econômica do imputado não obsta a investigação defensiva, que deve ser realizada pelo próprio Estado, por meio de defensor público, caso seja necessária para a defesa do imputado conforme estratégia a ser adotada.

Destaque-se, afinal, que, recentemente, houve alteração do rito do procedimento comum ordinário, por meio da Lei $\mathrm{n}^{\circ} 11.719 / 08$, que criou fase intermediária entre a persecução prévia e a ação penal, na qual o imputado pode demonstrar a insubsistência da acusação formulada.

Segundo a nova redação do artigo 396 do Código de Processo Penal, "nos procedimentos ordinário e sumário, oferecida a denúncia ou queixa, o juiz, se não a rejeitar liminarmente, recebê-la-á e ordenará a citação do acusado para responder à acusação, por escrito, no prazo de 10 (dez) dias”. 380

O artigo 396-A do Código de Processo Penal especifica o conteúdo da resposta do imputado, que "poderá argüir preliminares e alegar tudo o que interesse à sua defesa, oferecer documentos e justificações, especificar as provas pretendidas e arrolar testemunhas, qualificando-as e requerendo sua intimação, quando necessário”.

\footnotetext{
379 De acordo com o artigo $5^{\circ}$ da Lei Complementar n. ${ }^{\circ}$ 988/06, do Estado de São Paulo, são atribuições institucionais da Defensoria Pública: "atuar nos estabelecimentos policiais, penais e de internação, inclusive de adolescentes, visando a assegurar à pessoa, sob quaisquer circunstâncias, o exercício dos direitos e garantias individuais" (inciso VII); e "assegurar aos necessitados, em processo judicial ou administrativo, o contraditório e ampla defesa, com os meios e recursos a ela inerentes” (inciso IX).

Além disso, o artigo $6^{\circ}, \S 1^{\circ}$, da referida Lei Complementar, estabelece como direito do assistido obter informações precisas sobre: "a tramitação dos procedimentos administrativos e dos processos judiciais em que figure como interessado" (inciso IV); e "as decisões proferidas e a respectiva motivação, inclusive opiniões divergentes, constantes dos procedimentos administrativos e dos processos judiciais em que figure como interessado" (inciso V).

${ }^{380}$ Conforme analisado no tópico III.6.3, na fase do artigo 396 do Código de Processo Penal, o Juiz simplesmente determina o processamento da inicial acusatória, se estiver formal e materialmente perfeita. Não há, ainda, o recebimento em sentido estrito da peça vestibular, com a conseqüente instauração da ação penal, que só ocorre no momento previsto no artigo 399 do Código de Processo Penal.
} 
Percebe-se a relevância desta defesa preliminar para o imputado, pois é “o momento processual oportuno para que o acusado - que, invariavelmente não tomou parte na construção dos elementos informativos - traga todos os elementos que repute aptos a impedir o recebimento da acusação. O objetivo, portanto, é o de evitar que acusações desprovidas de sustentabilidade, ou mesmo desde logo manifestamente infundadas, tenham prosseguimento, prolongando o drama individual, além de onerarem, desnecessariamente, o Estado". 381

Após examinar a resposta do imputado, o Magistrado pode receber a inicial acusatória, determinando a instauração da ação penal e o seu processamento, nos termos dos artigos 399 e seguintes do Código de Processo Penal; ou absolver sumariamente o imputado, se presente uma das hipóteses estabelecidas no artigo 397 do Código de Processo Penal. $^{382}$

Com a instituição deste contraditório preliminar, tornou-se indispensável a previsão de investigação defensiva pelo ordenamento jurídico pátrio. Somente por meio desta atividade investigatória o imputado terá condições de reunir elementos para embasar a sua resposta preliminar.

${ }^{381}$ ZILLI, Marcos Alexandre Coelho, "Hamlet entre nós”..., p. 06.

${ }^{382}$ Reza o artigo 397 do Código de Processo Penal que o Juiz deve absolver sumariamente o acusado quando verificar: (i) a existência manifesta de causa excludente da ilicitude do fato; (ii) a existência manifesta de causa excludente da culpabilidade do agente, salvo inimputabilidade; (iii) que o fato narrado evidentemente não constitui crime; ou (iv) extinta a punibilidade do agente. 


\section{CONSIDERAÇÕES FINAIS}

A investigação criminal é procedimento preliminar e preparatório à ação penal, composto por um conjunto de atos encadeados, que podem ser praticados pelos sujeitos envolvidos na persecução penal, com a finalidade de reunir informes relacionados aos fatos constantes da notícia de crime.

Este procedimento possui dupla função: preservadora, porque inibe a instauração de ação penal infundada e, com isso, resguarda a liberdade do inocente e evita custos desnecessários para o Estado; e preparatória, porque acautela meios de prova que poderiam desaparecer com o decurso do tempo.

Os atos de investigação criminal não são atos de prova, porque são produzidos sem a observância das garantias fundamentais da publicidade, do contraditório e da ampla defesa. Por isso, servem apenas para fundamentar as decisões interlocutórias proferidas nesta fase, bem como justificar eventual ação penal ou o arquivamento do feito. Não amparam, portanto, as decisões tomadas durante o processo.

Excepcionalmente, são realizados atos de prova na fase investigatória, por meio de incidente probatório, caso exista o risco de perecimento ou não possam ser refeitos na instrução processual.

No tocante ao aspecto subjetivo do titular da investigação criminal, é possível qualificá-la em pública, se for desenvolvida por órgãos estatais (Ministério Público, Polícia Judiciária ou Juiz de Direito); ou privada, se for conduzida por um particular (o defensor do imputado, do ofendido ou de qualquer outra parte privada). Nessa ótica, a investigação defensiva pode ser considerada espécie de investigação privada, por ser efetuada pelo defensor do imputado.

Atualmente, vários países vêm implementando reformas em seus sistemas processuais penais, com o escopo de atribuir a investigação pública ao Parquet. No Brasil, debate-se a possibilidade de investigação ministerial, apesar de o texto constitucional prever, unicamente, a Polícia Judiciária como responsável pela atividade investigatória, sob a fiscalização do Ministério Público e do Juiz. 
O modelo de investigação criminal brasileiro, por excelência, é o inquérito policial, definido como procedimento cautelar, de natureza administrativa, quanto à forma, e judiciária, quanto à finalidade, destinado a colher dados sobre a materialidade e a autoria de suposto fato criminoso.

A Autoridade Policial preside o inquérito policial, sem qualquer tipo de subordinação funcional ao Ministério Público. Cabe à Polícia Judiciária, precipuamente, colher os primeiros dados informativos e impedir o perecimento dos elementos materiais relacionados à prática delituosa noticiada.

O Juiz, no curso do inquérito policial, deve verificar a legalidade das diligências efetuadas pela Autoridade Policial e tutelar direitos fundamentais do imputado. Qualquer ato investigatório que acarrete restrição a direitos individuais depende de prévia autorização judicial, que analisará a presença dos pressupostos legais e a proporcionalidade da medida.

É vedada a prática de atos investigatórios pelo Juiz, pois tal atividade pressupõe pré-julgamentos a respeito da imputação e, por conseguinte, atinge a sua imparcialidade. Contudo, nada obsta a iniciativa instrutória do Magistrado, que pode determinar a produção de provas durante o processo, desde que de forma subsidiária às partes e como instrumento para suprir as desigualdades naturais entre elas existentes.

O Ministério Público pode intervir no inquérito policial, por meio da requisição de diligências necessárias à formação da sua opinio delicti e da fiscalização da atividade da Polícia Judiciária.

Desde a persecução prévia, o órgão ministerial assume a posição de parte acusadora, legitimada a levar em Juízo a pretensão punitiva estatal. Por isso, sua atuação, nesta fase, já é dirigida a comprovar a prática da infração penal. No entanto, a parcialidade do Ministério Público não elide o dever de lealdade e isenção inerente à sua condição de fiscal da lei e órgão estatal. Por isso, o Parquet deve investigar fatos favoráveis ao imputado.

A vítima também tem o direito de participar ativamente do inquérito policial, em razão do seu legítimo interesse de ver punido o autor da infração penal e de ser ressarcida pelos danos materiais resultantes da conduta criminosa. 
Por sua vez, o imputado é visto, hoje em dia, como sujeito de direitos dentro do inquérito policial e não mero objeto de investigação. Por tal razão, desfruta de todas as prerrogativas estabelecidas no texto constitucional. Logo, o imputado deve saber a qualidade em que está sendo investigado (como suspeito ou indiciado), pois o indiciamento gera diversos direitos e obrigações para o sujeito passivo da investigação preliminar.

Todavia, a legislação processual penal brasileira não regula o ato de indiciamento, permitindo arbítrios por parte da Autoridade Policial, que, não raras vezes, retarda tal providência para tolher direitos do imputado. Apesar da omissão legislativa, a Autoridade Policial deve proceder ao indiciamento, sempre que convergirem elementos de convicção aptos a formar juízo de probabilidade acerca da autoria.

Desde a promulgação da atual Carta Constitucional, o processo penal brasileiro passou a adotar o modelo acusatório, marcado pela separação das funções de acusar, defender e julgar, e por alguns postulados básicos, com destaque para a igualdade, o contraditório e a ampla defesa.

A partir daí, surgiu discussão a respeito da incidência do contraditório e da ampla defesa na persecução preliminar, principalmente em razão da obtusa redação do artigo 5º LV, da Constituição da República.

Sem embargo da divergência doutrinária, não se vislumbra contraditório no inquérito policial, pois, neste momento, há intervenção restrita do imputado para proteção de seus direitos fundamentais. Inexiste a possibilidade de participação e de reação, com a capacidade de influenciar o julgador - o que desfigura totalmente esta garantia processual. Além do mais, o contraditório constituiria verdadeiro entrave ao desenvolvimento da investigação criminal.

Em contrapartida, é inegável que, na fase investigatória, há imputação criminal em face de determinada pessoa. Por conseguinte, nasce o correlato direito de defesa para o imputado, que tem o legítimo interesse de evitar a aplicação de medidas cautelares descabidas ou o advento de ação penal infundada.

Um dos aspectos do direito de defesa é o direito à prova, conceituado como a possibilidade de as partes reunirem material probatório a fim de demonstrar a veracidade 
de suas alegações. Como conseqüência, deve-se permitir a busca de fontes de prova, de onde se infere o direito à investigação.

Como expressão destes direitos, no âmbito do inquérito policial, há a faculdade de o imputado requerer diligências, prevista no artigo 14 do Código de Processo Penal. Demonstrada a pertinência e relevância deste pedido, a Autoridade Policial deve determinar a sua execução.

A participação do defensor nos autos da investigação pública não se confunde com a investigação defensiva. No primeiro caso, o defensor está circunscrito aos rumos dados à persecução prévia pelo órgão público e sua intervenção restringe-se à proteção dos interesses mais relevantes do imputado. No segundo, cabe ao defensor traçar a estratégia investigatória, sem qualquer tipo de subordinação às autoridades públicas, devendo apenas respeitar os critérios constitucionais e legais de obtenção de prova.

Nessa trilha, pode-se conceituar a investigação defensiva como procedimento investigatório realizado pelo defensor do imputado, em qualquer momento da persecução penal, com o eventual auxílio de assistentes técnicos, apartado dos autos da investigação pública, com o objetivo de reunir elementos favoráveis a seu cliente.

Em um processo penal de partes, a investigação defensiva é fundamental para garantir o equilíbrio entre acusação e defesa, pois serve para concretizar os direitos fundamentais à igualdade e à defesa.

De acordo com o princípio da isonomia, as partes devem ter paridade de armas, ou seja, os mesmos direitos, ônus e deveres, em cada grau e estado do procedimento. Assim, se um sistema jurídico prevê investigação pública propensamente acusatória, seja dirigida pelo Ministério Público ou por qualquer outro órgão, também deve admitir a atividade investigatória do defensor do imputado, para suportar as teses defensivas.

Já o direito de defesa, em suas facetas do direito à prova e à investigação, preceitua a possibilidade de reagir aos atos da parte contrária com meios de prova lícitos. Para o exercício eficaz deste direito, é indispensável que o imputado possa colher elementos probatórios, desde a fase preliminar, por meio da investigação defensiva. 
A investigação defensiva é algo comum e bastante utilizado nos Estados Unidos da América, por ser conseqüência natural do regime jurídico adotado neste país, que atribui às partes a iniciativa investigatória e probatória e lhes confere ampla liberdade no desempenho desta atividade.

Por outro lado, nos países de cultura jurídica romano-germânica, a atividade investigatória do defensor é novidade e, até o momento, foi positivada e regulamentada apenas no Direito italiano.

Com efeito, em 1988, a legislação processual penal italiana sofreu sensível reforma que culminou na implantação de um processo penal com contornos acusatórios. Nesse passo, houve a substituição do modelo investigatório do juizado de instrução pela investigação ministerial. Para assegurar a isonomia entre as partes, também foram fixados poderes investigatórios para os defensores do imputado e das demais partes privadas.

Assim, foi editada a Lei n. ${ }^{o}$ 397/2000, que criou procedimento específico de investigação defensiva, com regras a respeito da execução e documentação da atividade investigatória do defensor, e da utilização e valoração do seu resultado.

A incorporação da investigação defensiva no ordenamento jurídico italiano vem suscitando diversas questões, ainda intranqüilas, entre os jurisconsultos daquele país. Cite-se, por exemplo, a falta de poder de polícia do defensor no exercício de atos investigatórios; a qualificação pública ou privada da atividade de documentação dos atos investigatórios; a conciliação da investigação defensiva com o tratamento de dados pessoais e a prática de atos investigatórios atípicos.

A experiência italiana revela que é possível e desejável a incorporação da investigação defensiva em um sistema jurídico acusatório. Tal instituto está claramente em harmonia com as idéias de eficiência e garantismo, que devem orientar o moderno processo penal. Isso porque, além de equiparar os poderes da acusação e da defesa no tocante à procura das fontes de prova, amplia o campo cognitivo do Magistrado, que terá conhecimento dos dados trazidos por ambas as partes para respaldar suas decisões.

Vê-se, portanto, que a investigação defensiva é um instrumento para efetivar os direitos de igualdade e de defesa do imputado e diminuir significativamente o risco de ações penais infundadas, evitando a movimentação inútil e custosa do Poder Judiciário. 
Por todos os motivos ora aduzidos, sugere-se a inserção da investigação defensiva na pauta do legislador brasileiro, que deve considerar seriamente a implementação deste instituto no processo penal pátrio.

O inquérito policial, por prestigiar o viés acusatório da investigação, não atende, a contento, a necessidade da defesa de obter informes favoráveis ao imputado, sendo mister o desenvolvimento de investigação particular. Para tanto, deve-se instituir procedimento detalhado, que estipule os principais aspectos formais e substanciais da atividade investigatória do defensor, em conformidade com as diretrizes constitucionais e os pressupostos da eficiência e do garantismo.

Manter o imputado refém de uma investigação pública, na qual ele pouco pode intervir, desrespeita os fundamentos de um processo penal acusatório e não se coaduna com um Estado Democrático de Direito. 


\section{APÊNDICE: REFERÊNCIAS À LEGISLAÇÃO ITALIANA}

\section{a) Constituição da República (consulta no site www.leggiweb.it e www.altalex.com).}

“Art. 24.

Tutti possono agire in giudizio per la tutela dei propri diritti e interessi legittimi.

La difesa è diritto inviolabile in ogni stato e grado del procedimento.

Sono assicurati ai non abbienti, con appositi istituti, i mezzi per agire e difendersi davanti ad ogni giurisdizione.

La legge determina le condizioni e i modi per la riparazione degli errori giudiziari.”

“Art. 111.

La giurisdizione si attua mediante il giusto processo regolato dalla legge.

Ogni processo si svolge nel contraddittorio tra le parti, in condizioni di parità, davanti a giudice terzo e imparziale. La legge ne assicura la ragionevole durata.

Nel processo penale, la legge assicura che la persona accusata di un reato sia, nel più breve tempo possibile, informata riservatamente della natura e dei motivi dell'accusa elevata a suo carico; disponga del tempo e delle condizioni necessari per preparare la sua difesa; abbia la facoltà, davanti al giudice, di interrogare o di far interrogare le persone che rendono dichiarazioni a suo carico, di ottenere la convocazione e l'interrogatorio di persone a sua difesa nelle stesse condizioni dell'accusa e l'acquisizione di ogni altro mezzo di prova a suo favore; sia assistita da un interprete se non comprende o non parla la lingua impiegata nel processo.

Il processo penale è regolato dal principio del contraddittorio nella formazione della prova. La colpevolezza dell'imputato non può essere provata sulla base di dichiarazioni rese da chi, per libera scelta, si è sempre volontariamente sottratto all'interrogatorio da parte dell'imputato o del suo difensore.

La legge regola i casi in cui la formazione della prova non ha luogo in contraddittorio per consenso dell'imputato o per accertata impossibilità di natura oggettiva o per effetto di provata condotta illecita.

Tutti i provvedimenti giurisdizionali devono essere motivati.

Contro le sentenze e contro i provvedimenti sulla libertà personale, pronunciati dagli organi giurisdizionali ordinari o speciali, è sempre ammesso ricorso in Cassazione per violazione di legge. Si può derogare a tale norma soltanto per le sentenze dei tribunali militari in tempo di guerra.

Contro le decisioni del Consiglio di Stato e della Corte dei conti il ricorso in Cassazione è ammesso per i soli motivi inerenti alla giurisdizione”.

\section{b) Código Penal (consulta no site www.leggiweb.it e www.altalex.com).}

“Art. 371-ter. False dichiarazioni al difensore.

Nelle ipotesi previste dall'articolo 391-bis, commi 1 e 2, del codice di procedura penale, chiunque, non essendosi avvalso della facoltà di cui alla lettera d) del comma 3 del medesimo articolo, rende dichiarazioni false è punito con la reclusione fino a quattro anni.

Il procedimento penale resta sospeso fino a quando nel procedimento nel corso del quale sono state assunte le dichiarazioni sia stata pronunciata sentenza di primo grado ovvero il procedimento sia stato anteriormente definito con archiviazione o con sentenza di non luogo a procedere”.

“Art. 378. Favoreggiamento personale. 
Chiunque, dopo che fu commesso un delitto per il quale la legge stabilisce la pena di morte (1) o l'ergastolo o la reclusione, e fuori dei casi di concorso nel medesimo, aiuta taluno a eludere le investigazioni dell'autorità, o a sottrarsi alle ricerche di questa, è punito con la reclusione fino a quattro anni.

Quando il delitto commesso è quello previsto dall'art. 416-bis, si applica, in ogni caso, la pena della reclusione non inferiore a due anni.

Se si tratta di delitti per i quali la legge stabilisce una pena diversa, ovvero di contravvenzioni, la pena è della multa fino a euro 516.

Le disposizioni di questo articolo si applicano anche quando la persona aiutata non è imputabile o risulta che non ha commesso il delitto.

(1) La pena di morte per i delitti previsti dal codice penale è stata abolita dall'art. 1 del D.Lgs.Lgt. 10 agosto 1944, n. 224".

“Art. 379-bis. Rivelazione di segreti inerenti a un procedimento penale.

Salvo che il fatto costituisca più grave reato, chiunque rivela indebitamente notizie segrete concernenti un procedimento penale, da lui apprese per avere partecipato o assistito ad un atto del procedimento stesso, è punito con la reclusione fino a un anno. La stessa pena si applica alla persona che, dopo avere rilasciato dichiarazioni nel corso delle indagini preliminari, non osserva il divieto imposto dal pubblico ministero ai sensi dell'articolo 391-quinquies del codice di procedura penale".

"Art. 479. Falsità ideologica commessa dal pubblico ufficiale in atti pubblici.

Il pubblico ufficiale, che, ricevendo o formando un atto nell'esercizio delle sue funzioni, attesta falsamente che un fatto è stato da lui compiuto o è avvenuto alla sua presenza, o attesta come da lui ricevute dichiarazioni a lui non rese, ovvero omette o altera dichiarazioni da lui ricevute, o comunque attesta falsamente fatti dei quali l'atto è destinato a provare la verità, soggiace alle pene stabilite nell'articolo 476”"

"Art. 481. Falsità ideologica in certificati commessa da persone esercenti un servizio di pubblica necessità.

Chiunque, nell'esercizio di una professione sanitaria o forense, o di un altro servizio di pubblica necessità, attesta falsamente, in un certificato, fatti dei quali l'atto è destinato a provare la verità, è punito con la reclusione fino a un anno o con la multa da euro 51 a euro 516.

Tali pene si applicano congiuntamente se il fatto è commesso a scopo di lucro”.

\section{c) Código de Processo Penal (consulta no site www.leggiweb.it e www.altalex.com).}

“Art. 60. Assunzione della qualità di imputato.

1. Assume la qualità di imputato la persona alla quale è attribuito il reato nella richiesta di rinvio a giudizio, di giudizio immediato, di decreto penale di condanna, di applicazione della pena a norma dell'art. 447 comma 1 , nel decreto di citazione diretta a giudizio e nel giudizio direttissimo.

2. La qualità di imputato si conserva in ogni stato e grado del processo, sino a che non sia più soggetta a impugnazione la sentenza di non luogo a procedere, sia divenuta irrevocabile la sentenza di proscioglimento o di condanna o sia divenuto esecutivo il decreto penale di condanna.

3. La qualità di imputato si riassume in caso di revoca della sentenza di non luogo a procedere e qualora sia disposta la revisione del processo".

“Art. 61. Estensione dei diritti e delle garanzie dell'imputato.

1. I diritti e le garanzie dell'imputato si estendono alla persona sottoposta alle indagini preliminari. 2. Alla stessa persona si estende ogni altra disposizione relativa all'imputato, salvo che sia diversamente stabilito". 
“Art. 131. Poteri coercitivi del giudice.

1. Il giudice, nell'esercizio delle sue funzioni, può chiedere l'intervento della polizia giudiziaria e, se necessario, della forza pubblica, prescrivendo tutto ciò che occorre per il sicuro e ordinato compimento degli atti ai quali procede".

“Art. 190. Diritto alla prova.

1. Le prove sono ammesse a richiesta di parte. Il giudice provvede senza ritardo con ordinanza escludendo le prove vietate dalla legge e quelle che manifestamente sono superflue o irrilevanti.

2. La legge stabilisce i casi in cui le prove sono ammesse di ufficio.

3. I provvedimenti sull'ammissione della prova possono essere revocati sentite le parti in contraddittorio".

“Art.190-bis. Requisiti della prova in casi particolari.

1. Nei procedimenti per taluno dei delitti indicati nell'articolo 51, comma 3-bis, quando è richiesto l'esame di un testimone o di una delle persone indicate nell'articolo 210 e queste hanno già reso dichiarazioni in sede di incidente probatorio o in dibattimento nel contraddittorio con la persona nei cui confronti le dichiarazioni medesime saranno utilizzate ovvero dichiarazioni i cui verbali sono stati acquisiti a norma dell'articolo 238, l'esame è ammesso solo se riguarda fatti o circostanze diversi da quelli oggetto delle precedenti dichiarazioni ovvero se il giudice o taluna delle parti lo ritengono necessario sulla base di specifiche esigenze.

1-bis. La stessa disposizione si applica quando si procede per uno dei reati previsti dagli articoli 600-bis, primo comma, 600-ter, 600-quater, anche se relativi al materiale pornográfico di cui all'articolo 600-quater.1, 600-quinquies, 609-bis, 609-ter, 609-quater, 609 quinquies e 609-octies del codice penale, se l'esame richiesto riguarda un testimone minore degli anni sedici”.

\section{"Libro 5: Indagini preliminari e udienza preliminare}

Titolo I: Disposizioni generali

Art. 326. Finalità delle indagini preliminari.

1. Il pubblico ministero e la polizia giudiziaria svolgono, nell'ambito delle rispettive attribuzioni, le indagini necessarie per le determinazioni inerenti all'esercizio dell'azione penale.

Art. 327. Direzione delle indagini preliminari.

1. Il pubblico ministero dirige le indagini e dispone direttamente della polizia giudiziaria che, anche dopo la comunicazione della notizia di reato, continua a svolgere attività di propria iniziativa secondo le modalità indicate nei successivi articoli.

Art. 327-bis. Attività investigativa del difensore.

1. Fin dal momento dell'incarico professionale, risultante da atto scritto, il difensore ha facoltà di svolgere investigazioni per ricercare ed individuare elementi di prova a favore del proprio assistito, nelle forme e per le finalità stabilite nel titolo VI-bis del presente libro.

2. La facoltà indicata al comma 1 può essere attribuita per l'esercizio del diritto di difesa, in ogni stato e grado del procedimento, nell'esecuzione penale e per promuovere il giudizio di revisione.

3. Le attività previste dal comma 1 possono essere svolte, su incarico del difensore, dal sostituto, da investigatori privati autorizzati e, quando sono necessarie specifiche competenze, da consulenti tecnici.

Art. 328. Giudice per le indagini preliminari.

1. Nei casi previsti dalla legge, sulle richieste del pubblico ministero, delle parti private e della persona offesa dal reato, provvede il giudice per le indagini preliminari. 
1-bis. Quando si tratta di procedimenti per i delitti indicati nell'art. 51 comma 3 bis e 3-quater, le funzioni di giudice per le indagini preliminari sono esercitate, salve specifiche disposizioni di legge, da un magistrato del tribunale del capoluogo del distretto nel cui ambito ha sede il giudice competente.

1-ter. Abrogato.

1-quater. Quando si tratta di procedimenti per i delitti indicati nell'articolo 51, comma 3-quinquies, le funzioni di giudice per le indagini preliminari e le funzioni di giudice per l'udienza preliminare sono esercitate, salve specifiche disposizioni di legge, da um magistrato del tribunale del capoluogo del distretto nel cui ambito ha sede il giudice competente.

Art. 329. Obbligo del segreto.

1. Gli atti di indagine compiuti dal pubblico ministero e dalla polizia giudiziaria sono coperti dal segreto fino a quando l'imputato non ne possa avere conoscenza e, comunque, non oltre la chiusura delle indagini preliminari.

2. Quando è necessario per la prosecuzione delle indagini, il pubblico ministero può, in deroga a quanto previsto dall'articolo 114, consentire, con decreto motivato, la pubblicazione di singoli atti o di parti di essi. In tal caso, gli atti pubblicati sono depositati presso la segreteria del pubblico ministero.

3. Anche quando gli atti non sono più coperti dal segreto a norma del comma 1, il pubblico ministero, in caso di necessità per la prosecuzione delle indagini, può disporre con decreto motivato:

a) l'obbligo del segreto per singoli atti, quando l'imputato lo consente o quando la conoscenza dell'atto può ostacolare le indagini riguardanti altre persone;

b) il divieto di pubblicare il contenuto di singoli atti o notizie specifiche relative a determinate operazioni.

\section{Titolo II: Notizia di reato}

Art. 330. Acquisizione delle notizie di reato.

l. Il pubblico ministero e la polizia giudiziaria prendono notizia dei reati di propria iniziativa e ricevono le notizie di reato presentate o trasmesse a norma degli articoli seguenti.

Art. 331. Denuncia da parte di pubblici ufficiali e incaricati di un pubblico servizio.

1. Salvo quanto stabilito dall'art. 347, i pubblici ufficiali e gli incaricati di un pubblico servizio che, nell'esercizio o a causa delle loro funzioni o del loro servizio, hanno notizia di reato perseguibile di ufficio, devono farne denuncia per iscritto, anche quando non sia individuata la persona alla quale il reato è attribuito.

2. La denuncia è presentata o trasmessa senza ritardo al pubblico ministero o a un ufficiale di polizia giudiziaria.

3. Quando più persone sono obbligate alla denuncia per il medesimo fatto, esse possono anche redigere e sottoscrivere un unico atto.

4. Se, nel corso di un procedimento civile o amministrativo, emerge un fatto nel quale si può configurare un reato perseguibile di ufficio, l'autorità che procede redige e trasmette senza ritardo la denuncia al pubblico ministero.

Art. 332. Contenuto della denuncia.

1. La denuncia contiene la esposizione degli elementi essenziali del fatto e indica il giorno dell'acquisizione della notizia nonché le fonti di prova già note. Contiene inoltre, quando è possibile, le generalità, il domicilio e quanto altro valga alla identificazione della persona alla quale il fatto è attribuito, della persona offesa e di coloro che siano in grado di riferire su circostanze rilevanti per la ricostruzione dei fatti.

Art. 333. Denuncia da parte di privati.

1. Ogni persona che ha notizia di un reato perseguibile di ufficio può farne denuncia. La legge determina i casi in cui la denuncia è obbligatoria.

2. La denuncia è presentata oralmente o per iscritto, personalmente o a mezzo di procuratore speciale, al pubblico ministero o a un ufficiale di polizia giudiziaria; se è presentata per iscritto, è sottoscritta dal 
denunciante o da un suo procuratore speciale.

3. Delle denuncie anonime non può essere fatto alcun uso, salvo quanto disposto dall'articolo 240.

Art. 334. Referto.

1. Chi ha l'obbligo del referto deve farlo pervenire entro quarantotto ore o, se vi è pericolo nel ritardo, immediatamente al pubblico ministero o a qualsiasi ufficiale di polizia giudiziaria del luogo in cui ha prestato la propria opera o assistenza ovvero, in loro mancanza, all'ufficiale di polizia giudiziaria più vicino.

2. Il referto indica la persona alla quale è stata prestata assistenza e, se è possibile, le sue generalità, il luogo dove si trova attualmente e quanto altro valga a identificarla nonché il luogo, il tempo e le altre circostanze dell'intervento; dà inoltre le notizie che servono a stabilire le circostanze del fatto, i mezzi con i quali è stato commesso e gli effetti che ha causato o può causare.

3. Se più persone hanno prestato la loro assistenza nella medesima occasione, sono tutte obbligate al referto, con facoltà di redigere e sottoscrivere un unico atto.

Art. 334-bis. Esclusione dell'obbligo di denuncia nell'ambito dell'attività di investigazioni difensiva.

1. Il difensore e gli altri soggetti di cui all'articolo 391-bis non hanno obbligo di denuncia neppure relativamente ai reati dei quali abbiano avuto notizia nel corso delle attività investigative da essi svolte.

Art. 335. Registro delle notizie di reato.

1. Il pubblico ministero iscrive immediatamente, nell'apposito registro custodito presso l'ufficio, ogni notizia di reato che gli perviene o che ha acquisito di propria iniziativa nonché, contestualmente o dal momento in cui risulta, il nome della persona alla quale il reato stesso è attribuito.

2. Se nel corso delle indagini preliminari muta la qualificazione giuridica del fatto ovvero questo risulta diversamente circostanziato, il pubblico ministero cura l'aggiornamento delle iscrizioni previste dal comma I senza procedere a nuove iscrizioni.

3. Ad esclusione dei casi in cui si procede per uno dei delitti di cui all'articolo 407, comma 2 lettera a, le iscrizioni previste dai commi 1 e 2 sono comunicate alla persona alla quale il reato è attribuito, alla persona offesa e ai rispettivi difensori, ove ne facciano richiesta.

3-bis. Se sussistono specifiche esigenze attinenti all'attività di indagine, il pubblico ministero, nel decidere sulla richiesta, può disporre, con decreto motivato, il segreto sulle iscrizioni per un periodo non superiore a tre mesi e non rinnovabile.

\section{Titolo III: Condizioni di procedibilità}

Art. 336. Querela.

1. La querela è proposta mediante dichiarazione nella quale, personalmente o a mezzo di procuratore speciale, si manifesta la volontà che si proceda in ordine a un fatto previsto dalla legge come reato.

Art. 337. Formalità della querela.

1. La dichiarazione di querela è proposta, con le forme previste dall'art. 333 comma 2, alle autorità alle quali può essere presentata denuncia ovvero a un agente consolare all'estero. Essa, con sottoscrizione autentica, può essere anche recapitata da un incaricato o spedita per posta in piego raccomandato.

2. Quando la dichiarazione di querela è proposta oralmente, il verbale in cui essa è ricevuta è sottoscritto dal querelante o dal procuratore speciale.

3. La dichiarazione di querela proposta dal legale rappresentante di una persona giuridica, di un ente o di una associazione deve contenere la indicazione specifica della fonte dei poteri di rappresentanza.

4. L'autorità che riceve la querela provvede all'attestazione della data e del luogo della presentazione, all'identificazione della persona che la propone e alla trasmissione degli atti all'ufficio del pubblico ministero.

Art. 338. Curatore speciale per la querela.

1. Nel caso previsto dall'art. 121 c.p., il termine per la presentazione della querela decorre dal giorno in cui è 
notificato al curatore speciale il provvedimento di nomina.

2. Alla nomina provvede, con decreto motivato, il giudice per le indagini preliminari del luogo in cui si trova la persona offesa, su richiesta del pubblico ministero.

3. La nomina può essere promossa anche dagli enti che hanno per scopo la cura, l'educazione, la custodia o l'assistenza dei minorenni.

4. Il curatore speciale ha facoltà di costituirsi parte civile nell'interesse della persona offesa.

5. Se la necessità della nomina del curatore speciale sopravviene dopo la presentazione della querela, provvede il giudice per le indagini preliminari o il giudice che procede.

Art. 339. Rinuncia alla querela.

1. La rinuncia espressa alla querela è fatta personalmente o a mezzo di procuratore speciale, con dichiarazione sottoscritta, rilasciata all'interessato o a un suo rappresentante. La dichiarazione può anche essere fatta oralmente a un ufficiale di polizia giudiziaria o a un notaio, i quali, accertata l'identità del rinunciante, redigono verbale. Questo non produce effetti se non è sottoscritto dal dichiarante.

2. La rinuncia sottoposta a termini o a condizioni non produce effetti.

3. Con la stessa dichiarazione può essere fatta rinuncia anche all'azione civile per le restituzioni e per il risarcimento del danno.

Art. 340. Remissione della querela.

1. La remissione della querela è fatta e accettata personalmente o a mezzo di procuratore speciale, con dichiarazione ricevuta dall'autorità procedente o da un ufficiale di polizia giudiziaria che deve trasmetterla immediatamente alla predetta autorità.

2. La dichiarazione di remissione e quella di accettazione sono fatte con le forme previste per la rinuncia espressa alla querela.

3. Il curatore speciale previsto dall'articolo 155 comma 4 c.p. è nominato a norma dell'articolo 338.

4. Le spese del procedimento sono a carico del querelato, salvo che nell'atto di remissione sia stato diversamente convenuto.

Art. 341. Istanza di procedimento.

1. L'istanza di procedimento è proposta dalla persona offesa con le forme della querela.

Art. 342. Richiesta di procedimento.

1. La richiesta di procedimento è presentata al pubblico ministero con atto sottoscritto dall'autorità competente.

Art. 343. Autorizzazione a procedere.

1. Qualora sia prevista l'autorizzazione a procedere, il pubblico ministero ne fa richiesta a norma dell'articolo 344.

2. Fino a quando non sia stata concessa l'autorizzazione, è fatto divieto di disporre il fermo o misure cautelari personali nei confronti della persona rispetto alla quale è prevista l'autorizzazione medesima nonché di sottoporla a perquisizione personale o domiciliare, a ispezione personale, a ricognizione, a individuazione, a confronto, a intercettazione di conversazioni o di comunicazioni. Si può procedere all'interrogatorio solo se l'interessato lo richiede.

3. Gli atti previsti dal comma 2 sono consentiti, anche prima della richiesta di autorizzazione, quando la persona è colta nella flagranza di uno dei delitti indicati nell'art. 380 commi 1 e 2. Tuttavia, quando l'autorizzazione a procedere o l'autorizzazione al compimento di determinati atti sono prescritte da disposizioni della Costituzione o di leggi costituzionali, si applicano tali disposizioni, nonché, in quanto compatibili con esse quelle di cui agli articoli 344, 345 e 346.

4. Gli atti compiuti in violazione di quanto stabilito nei commi 2 e 3 non possono essere utilizzati.

5. L'autorizzazione a procedere, una volta concessa, non può essere revocata.

Art. 344. Richiesta di autorizzazione a procedere. 
1. Il pubblico ministero chiede l'autorizzazione prima di procedere a giudizio direttissimo o di richiedere il giudizio immediato, il rinvio a giudizio, il decreto penale di condanna o di emettere il decreto di citazione a giudizio. La richiesta deve, comunque, essere presentata entro trenta giorni dalla iscrizione nel registro delle notizie di reato del nome della persona per la quale è necessaria l'autorizzazione.

2. Se la persona per la quale è necessaria l'autorizzazione è stata arrestata in flagranza, il pubblico ministero richiede l'autorizzazione a procedere immediatamente e comunque prima della udienza di convalida.

3. Il giudice sospende il processo e il pubblico ministero richiede senza ritardo l'autorizzazione a procedere qualora ne sia sorta la necessità dopo che si è proceduto a giudizio direttissimo ovvero dopo che sono state formulate le richieste previste dalla prima parte del comma 1 . Se vi è pericolo nel ritardo, il giudice provvede all'assunzione delle prove richieste dalle parti.

4. Quando si procede nei confronti di più persone per alcune delle quali soltanto è necessaria l'autorizzazione e questa tarda ad essere concessa, si può procedere separatamente contro gli imputati per i quali l'autorizzazione non è necessaria.

Art. 345. Difetto di una condizione di procedibilità. Riproponibilità dell'azione penale.

1. Il provvedimento di archiviazione e la sentenza di proscioglimento o di non luogo a procedere, anche se non più soggetta a impugnazione, con i quali è stata dichiarata la mancanza della querela della istanza, della richiesta o dell'autorizzazione a procedere, non impediscono l'esercizio dell'azione penale per il medesimo fatto e contro la medesima persona se è in seguito proposta la querela, l'istanza, la richiesta o è concessa l'autorizzazione ovvero se è venuta meno la condizione personale che rendeva necessaria l'autorizzazione.

2. La stessa disposizione si applica quando il giudice accerta la mancanza di una condizione di procedibilità diversa da quelle indicate nel comma 1.

Art. 346. Atti compiuti in mancanza di una condizione di procedibilità.

1. Fermo quanto disposto dall'articolo 343, in mancanza di una condizione di procedibilità che può ancora sopravvenire, possono essere compiuti gli atti di indagine preliminare necessari ad assicurare le fonti di prova e, quando vi è pericolo nel ritardo, possono essere assunte le prove previste dall'articolo 392.

Titolo IV: Attività a iniziativa della polizia giudiziaria

Art. 347. Obbligo di riferire la notizia del reato.

1. Acquisita la notizia di reato, la polizia giudiziaria, senza ritardo, riferisce al pubblico ministero, per iscritto, gli elementi essenziali del fatto e gli altri elementi sino ad allora raccolti, indicando le fonti di prova e le attività compiute, delle quali trasmette la relativa documentazione.

2. Comunica, inoltre, quando è possibile, le generalità, il domicilio e quanto altro valga alla identificazione della persona nei cui confronti vengono svolte le indagini, della persona offesa e di coloro che siano in grado di riferire su circostanze rilevanti per la ricostruzione dei fatti.

2-bis. Qualora siano stati compiuti atti per i quali è prevista l'assistenza del difensore (350, 352, 353-2, 354 ) della persona nei cui confronti vengono svolte le indagini (61), la comunicazione della notizia di reato è trasmessa al più tardi entro quarantotto ore dal compimento dell'atto, salve le disposizioni di legge che prevedono termini particolari.

3. Se si tratta di taluno dei delitti indicati nell'art. 275 , comma 3, e, in ogni caso, quando sussistono ragioni di urgenza, la comunicazione della notizia di reato è data immediatamente anche in forma orale. Alla comunicazione orale deve seguire senza ritardo quella scritta con le indicazioni e la documentazione previste dai commi 1 e 2.

4. Con la comunicazione, la polizia giudiziaria indica il giorno e l'ora in cui ha acquisito la notizia.

Art. 348. Assicurazione delle fonti di prova.

1. Anche successivamente alla comunicazione della notizia di reato, la polizia giudiziaria continua a svolgere le funzioni Indicate nell'art. 55 raccogliendo in specie ogni elemento utile alla ricostruzione del fatto e alla 
individuazione del colpevole.

2. Al fine indicato nel comma 1, procede, fra l'altro:

a) alla ricerca delle cose e delle tracce pertinenti al reato nonchè alla conservazione di esse e dello stato dei luoghi;

b) alla ricerca delle persone in grado di riferire su circostanze rilevanti per la ricostruzione dei fatti; c) al compimento degli atti indicati negli articoli seguenti.

3. Dopo l'intervento del pubblico ministero, la polizia giudiziaria compie gli atti a essa specificamente delegati a norma dell'articolo 370, esegue le direttive del pubblico ministero ed inoltre svolge di propria iniziativa, informandone prontamente il pubblico ministero, tutte le altre attività di indagine per accertare i reati ovvero richieste da elementi successivamente emersi e assicura le nuove fonti di prova.

4. La polizia giudiziaria, quando, di propria iniziativa o a seguito di delega del pubblico ministero, compie atti od operazioni che richiedono specifiche competenze tecniche, può avvalersi di persone idonee le quali non possono rifiutare la propria opera.

Art. 349. Identificazione della persona nei cui confronti vengono svolte le indagini e di altre persone.

1. La polizia giudiziaria procede alla identificazione della persona nei cui confronti vengono svolte le indagini e delle persone in grado di riferire su circostanze rilevanti per la ricostruzione dei fatti.

2. Alla identificazione della persona nei cui confronti vengono svolte le indagini può procedersi anche eseguendo, ove occorra, rilievi dattiloscopici, fotografici e antropometrici nonché altri accertamenti.

2-bis. Se gli accertamenti indicati dal comma 2 il prelievo di capelli o saliva e manca il consenso dell'interessato, la polizia giudiziaria procede al prelievo coattivo nel rispetto della dignità personale del soggetto, previa autorizzazione scritta, oppure resa oralmente e confermata per iscritto, del pubblico ministero.

3. Quando procede alla identificazione, la polizia giudiziaria invita la persona nei cui confronti vengono svolte le indagini a dichiarare o a eleggere il domicilio per le notificazioni a norma dell'articolo 161. Osserva inoltre le disposizioni dell'articolo 66.

4. Se taluna delle persone indicate nel comma 1 rifiuta di farsi identificare ovvero fornisce generalità o documenti di identificazione in relazione ai quali sussistono sufficienti elementi per ritenerne la falsità, la polizia giudiziaria la accompagna nei propri uffici e ivi la trattiene per il tempo strettamente necessario per la identificazione e comunque non oltre le dodici ore ovvero, prévio avviso anche orale al pubblico ministero, non oltre le ventiquattro ore, nel caso che l'identificazione risulti particolarmente complessa oppure occorra l'assistenza dell'autorità consolare o di un interprete, ed in tal caso con facoltà per il soggetto di chiedere di avvisare un familiare o un convivente.

5. Dell'accompagnamento e dell'ora in cui questo è stato compiuto è data immediata notizia al pubblico ministero il quale, se ritiene che non ricorrono le condizioni previste dal comma 4, ordina il rilascio della persona accompagnata.

6. Al pubblico ministero è data altresì notizia del rilascio della persona accompagnata e dell'ora in cui esso è avvenuto.

Art. 350. Sommarie informazioni dalla persona nei cui confronti vengono svolte le indagini.

1. Gli ufficiali di polizia giudiziaria assumono, con le modalità previste dall'articolo 64, sommarie informazioni utili per le investigazioni dalla persona nei cui confronti vengono svolte le indagini che non si trovi in stato di arresto o di fermo a norma dell'articolo 384.

2. Prima di assumere le sommarie informazioni, la polizia giudiziaria invita la persona nei cui confronti vengono svolte le indagini a nominare un difensore di fiducia e, in difetto, provvede a norma dell'articolo 97 comma 3.

3. Le sommarie informazioni sono assunte con la necessaria assistenza del difensore, al quale la polizia giudiziaria dà tempestivo avviso. Il difensore ha l'obbligo di presenziare al compimento dell'atto.

4. Se il difensore non è stato reperito o non è comparso, la polizia giudiziaria richiede al pubblico ministero di provvedere a norma dell'articolo 97, comma 4.

5. Sul luogo o nell'immediatezza del fatto, gli ufficiali di polizia giudiziaria possono, anche senza la presenza 
del difensore, assumere dalla persona nei cui confronti vengono svolte le indagini, anche se arrestata in flagranza o fermata a norma dell'articolo 384, notizie e indicazioni utili ai fini della immediata prosecuzione delle indagini.

6. Delle notizie e delle indicazioni assunte senza l'assistenza del difensore sul luogo o nell'immediatezza del fatto a norma del comma 5 è vietata ogni documentazione e utilizzazione.

7. La polizia giudiziaria può altresì ricevere dichiarazioni spontanee dalla persona nei cui confronti vengono svolte le indagini, ma di esse non è consentita la utilizzazione nel dibattimento, salvo quanto previsto dall'articolo 503, comma 3.

Art. 351. Altre sommarie informazioni.

1. La polizia giudiziaria assume sommarie informazioni dalle persone che possono riferire circostanze utili ai fini delle indagini. Si applica la disposizione del secondo e terzo periodo del comma 1 dell'articolo 362.

1-bis. All'assunzione di informazioni da persona imputata in un procedimento connesso ovvero da persona imputata di un reato collegato a quello per cui si procede nel caso previsto dall'articolo 371, comma 2, lettera b, procede un ufficiale di polizia giudiziaria. La persona predetta, se priva del difensore, è avvisata che è assistita da un difensore di ufficio, ma che può nominarne uno di fiducia. Il difensore deve essere tempestivamente avvisato e ha diritto di assistere all'atto.

Art. 352. Perquisizioni.

1. Nella flagranza del reato o nel caso di evasione, gli ufficiali di polizia giudiziaria procedono a perquisizione personale o locale quando hanno fondato motivo di ritenere che sulla persona si trovino occultate cose o tracce pertinenti al reato che possono essere cancellate o disperse ovvero che tali cose o tracce si trovino in un determinato luogo o che ivi si trovi la persona sottoposta alle indagini o l'evaso.

1-bis. Nella flagranza del reato, ovvero nei casi di cui al comma 2 quando sussistono i presupposti e le altre condizioni ivi previsti, gli ufficiali di polizia giudizaria, adottando misure tecniche dirette ad assicurare la conservazine dei datti originali e ad impedirne l'alterazione, procedono altresì all perquisizione di sistemi informatici o telematici, ancorche protetti da misure di sicurezza, quando hanno fondato motivo di ritenere che in questi si trovino occultati dati, informazioni, programmi informatici o tracce comunque pertinenti al reato che possono essere cancellati o dispersi.

2. Quando si deve procedere alla esecuzione di un'ordinanza che dispone la custodia cautelare o di un ordine che dispone la carcerazione nei confronti di persona imputata o condannata per uno dei delitti previsti dall'articolo 380 ovvero al fermo di una persona indiziata di delitto, gli ufficiali di polizia giudiziaria possono altresì procedere a perquisizione personale o locale se ricorrono i presupposti indicati nel comma $1 \mathrm{e}$ sussistono particolari motivi di urgenza che non consentono la emissione di un tempestivo decreto di perquisizione.

3. La perquisizione domiciliare può essere eseguita anche fuori dei limiti temporali dell'articolo 251 quando il ritardo potrebbe pregiudicarne l'esito.

4. La polizia giudiziaria trasmette senza ritardo, e comunque non oltre le quarantotto ore, al pubblico ministero del luogo dove la perquisizione è stata eseguita il verbale delle operazioni compiute. Il pubblico ministero, se ne ricorrono i presupposti, nelle quarantotto ore successive, convalida la perquisizione.

Art. 353. Acquisizione di plichi o di corrispondenza.

1. Quando vi è necessità di acquisire plichi sigillati o altrimenti chiusi, l'ufficiale di polizia giudiziaria li trasmette intatti al pubblico ministero per l'eventuale sequestro.

2. Se ha fondato motivo di ritenere che i plichi contengano notizie utili alla ricerca e all'assicurazione di fonti di prova che potrebbero andare disperse a causa del ritardo, l'ufficiale di polizia giudiziaria informa col mezzo più rapido il pubblico ministero il quale può autorizzarne l'apertura immediata e l'accertamento del contenuto.

3. Se si tratta di lettere, pieghi, pacchi, valori, telegrammi o altri oggetti di corrispondenza, anche se in forma elettronica o se inoltrati per via telemática, per i quali è consentito il sequestro a norma dell'articolo 254, gli ufficiali di polizia giudiziaria, in caso di urgenza, ordinano a chi è preposto al servizio postale, telegráfico, telematico o di telecomunicazione, di sospendere l'inoltro. Se entro quarantotto ore dall'ordine della polizia giudiziaria il pubblico ministero non dispone il sequestro, gli oggetti di corrispondenza sono inoltrati. 
Art. 354. Accertamenti urgenti sui luoghi, sulle cose e sulle persone. Seqüestro.

1. Gli ufficiali e gli agenti di polizia giudiziaria curano che le tracce e le cose pertinenti al reato siano conservate e che lo stato dei luoghi e delle cose non venga mutato prima dell'intervento del pubblico ministero.

2. Se vi è pericolo che le cose le tracce e i luoghi indicati nel comma 1 si alterino o si disperdano o comunque si modifichino e il pubblico ministero non può intervenire tempestivamente, ovvero non ha ancora assunto la direzione delle indagini, gli ufficiali di polizia giudiziaria compiono i necessari accertamenti e rilievi sullo stato dei luoghi e delle cose. In relazione ai datti, alle informazioni e ai programmi informatici o ai sistemi informatici o telematici, gli ufficiali della polizia giudiziaria adottano, altresì, le misure tecniche o impartiscono le prescrizioni necessarie ad assicurare la conservazione e ad impedirne l'alterazione e l'accesso e provvedono, ove possibile, alla loro immediata duplicazione su adeguati supporti, mediante una procedura che assicurila conformità della copia all'originale e la sua immodificabilità. Se del caso, sequestrano il corpo del reato e le cose a questo pertinenti.

3. Se ricorrono i presupposti previsti dal comma 2, gli ufficiali di polizia giudiziaria compiono i necessari accertamenti e rilievi sulle persone diversi dalla ispezione personale. Se gli accertamenti comportano il prelievo di materiale biologico, si osservano le disposizioni del comma 2-bis dell'articolo 349.

Art. 355. Convalida del sequestro e suo riesame.

1. Nel caso in cui abbia proceduto a sequestro, la polizia giudiziaria enuncia nel relativo verbale il motivo del provvedimento e ne consegna copia alla persona alla quale le cose sono state sequestrate. Il verbale è trasmesso senza ritardo, e comunque non oltre le quarantotto ore, al pubblico ministero del luogo dove il sequestro è stato eseguito.

2. Il pubblico ministero, nelle quarantotto ore successive, con decreto motivato convalida il sequestro se ne ricorrono i presupposti ovvero dispone la restituzione delle cose sequestrate. Copia del decreto di convalida è immediatamente notificata alla persona alla quale le cose sono state sequestrate.

3. Contro il decreto di convalida, la persona nei cui confronti vengono svolte le indagini e il suo difensore, la persona alla quale le cose sono state sequestrate e quella che avrebbe diritto alla loro restituzione possono proporre, entro dieci giorni dalla notifica del decreto ovvero dalla diversa data in cui l'interessato ha avuto conoscenza dell'avvenuto sequestro, richiesta di riesame, anche nel merito, a norma dell'articolo 324.

4. La richiesta di riesame non sospende l'esecuzione del provvedimento.

Art. 356. Assistenza del difensore.

1. Il difensore della persona nei cui confronti vengono svolte le indagini ha facoltà di assistere, senza diritto di essere preventivamente avvisato, agli atti previsti dagli articoli 352 e 354 oltre che all'immediata apertura del plico autorizzata dal pubblico ministero a norma dell'articolo 353 comma 2.

Art. 357. Documentazione dell'attività di polizia giudiziaria.

1. La polizia giudiziaria annota secondo le modalità ritenute idonee ai fini delle indagini, anche sommariamente, tutte le attività svolte, comprese quelle dirette alla individuazione delle fonti di prova.

2. Fermo quanto disposto in relazione a specifiche attività, redige verbale dei seguenti atti:

a) denuncie, querele e istanze presentate oralmente;

b) sommarie informazioni rese e dichiarazioni spontanee ricevute dalla persona nei cui confronti vengono svolte le indagini;

c) informazioni assunte, a norma dell'articolo 351;

d) perquisizioni e sequestri;

e) operazioni e accertamenti previsti dagli articoli 349, 353 e 354;

f) atti, che descrivono fatti e situazioni, eventualmente compiuti sino a che il pubblico ministero non ha impartito le direttive per lo svolgimento delle indagini.

3. Il verbale è redatto da ufficiali o agenti di polizia giudiziaria nelle forme e con le modalità previste dall'articolo 373.

4. La documentazione dell'attività di polizia giudiziaria è posta a disposizione del pubblico ministero. 
5. A disposizione del pubblico ministero sono altresì poste le denuncie, le istanze e le querele presentate per iscritto, i referti, il corpo del reato e le cose pertinenti al reato.

\section{Titolo V: Attività del Pubblico Ministero}

Art. 358. Attività di indagine del pubblico ministero.

1. Il pubblico ministero compie ogni attività necessaria ai fini indicati nell'articolo 326 e svolge altresì accertamenti su fatti e circostanze a favore della persona sottoposta alle indagini.

Art. 359. Consulenti tecnici del pubblico ministero.

1. Il pubblico ministero, quando procede ad accertamenti, rilievi segnaletici, descrittivi o fotografici e ad ogni altra operazione tecnica per cui sono necessarie specifiche competenze, può nominare e avvalersi di consulenti, che non possono rifiutare la loro opera.

2. Il consulente può essere autorizzato dal pubblico ministero ad assistere a singoli atti di indagine.

Art. 360. Accertamenti tecnici non ripetibili.

1. Quando gli accertamenti previsti dall'articolo 359 riguardano persone, cose o luoghi il cui stato è soggetto a modificazione, il pubblico ministero avvisa, senza ritardo, la persona sottoposta alle indagini, la persona offesa dal reato e i difensori del giorno, dell'ora e del luogo fissati per il conferimento dell'incarico e della facoltà di nominare consulenti tecnici.

2. Si applicano le disposizioni dell'articolo 364 comma 2.

3. I difensori nonchè i consulenti tecnici eventualmente nominati hanno diritto di assistere al conferimento dell'incarico, di partecipare agli accertamenti e di formulare osservazioni e riserve.

4. Qualora, prima del conferimento dell'incarico, la persona sottoposta alle indagini formuli riserva di promuovere incidente probatorio, il pubblico ministero dispone che non si proceda agli accertamenti salvo che questi, se differiti, non possano più essere utilmente compiuti.

5. Se il pubblico ministero, malgrado l'espressa riserva formulata dalla persona sottoposta alle indagini e pur non sussistendo le condizioni indicate nell'ultima parte del comma 4, ha ugualmente disposto di procedere agli accertamenti, i relativi risultati non possono essere utilizzati nel dibattimento.

Art. 361. Individuazione di persone e di cose.

1. Quando è necessario per la immediata prosecuzione delle indagini, il pubblico ministero procede alla individuazione di persone, di cose o di quanto altro può essere oggetto di percezione sensoriale.

2. Le persone, le cose e gli altri oggetti sono presentati ovvero sottoposti in immagine a chi deve eseguire la individuazione.

3. Se ha fondata ragione di ritenere che la persona chiamata alla individuazione possa subire intimidazione o altra influenza dalla presenza di quella sottoposta a individuazione, il pubblico ministero adotta le cautele previste dall'articolo 214 comma 2.

Art. 362. Assunzione di informazioni.

1. Il pubblico ministero assume informazioni dalle persone che possono riferire circostanze utili ai fini delle indagini. Alle persone già sentite dal difensore o dal suo sostituto non possono essere chieste informazioni sulle domande formulate e sulle risposte date. Si applicano le disposizioni degli articoli 197, 197-bis, 198, 199, 200, 201, 202 e 203.

Art. 363. Interrogatorio di persona imputata a un procedimento connesso.

1. Le persone imputate in un procedimento connesso a norma dell'articolo 12 sono interrogate dal pubblico ministero sui fatti per cui si procede nelle forme previste dall'articolo 210 commi 2, 3, 4 e 6 .

2. La disposizione del comma 1 si applica anche alle persone imputate di un reato collegato a quello per cui si procede, nel caso previsto dall'articolo 371, comma 2, lettera b. 
Art. 364. Nomina e assistenza del difensore.

1. Il pubblico ministero, se deve procedere a interrogatorio, ovvero a ispezione o confronto cui deve partecipare la persona sottoposta alle indagini, la invita a presentarsi a norma dell'articolo 375.

2. La persona sottoposta alle indagini priva del difensore è altresì avvisata che è assistita da un difensore di ufficio, ma che può nominarne uno di fiducia.

3. Al difensore di ufficio o a quello di fiducia in precedenza nominato è dato avviso almeno ventiquattro ore prima del compimento degli atti indicati nel comma 1 e delle ispezioni a cui non deve partecipare la persona sottoposta alle indagini.

4. Il difensore ha in ogni caso diritto di assistere agli atti indicati nei commi 1 e 3 fermo quanto previsto dall'articolo 245.

5. Nei casi di assoluta urgenza, quando vi è fondato motivo di ritenere che il ritardo possa pregiudicare la ricerca o l'assicurazione delle fonti di prova, il pubblico ministero può procedere a interrogatorio, a ispezione o a confronto anche prima del termine fissato dandone avviso al difensore senza ritardo e comunque tempestivamente. L'avviso può essere omesso quando il pubblico ministero procede a ispezione e vi è fondato motivo di ritenere che le tracce o gli altri effetti materiali del reato possano essere alterati. E' fatta salva, in ogni caso, la facoltà del difensore d'intervenire.

6. Quando procede nei modi previsti dal comma 5, il pubblico ministero deve specificamente indicare, a pena di nullità, i motivi della deroga e le modalità dell'avviso.

7. E' vietato a coloro che intervengono agli atti di fare segni di approvazione o disapprovazione. Quando assiste al compimento degli atti, il difensore può presentare al pubblico ministero richieste, osservazioni e riserve delle quali è fatta menzione nel verbale.

Art. 365. Atti ai quali il difensore ha diritto di assistere senza avviso.

1. Il pubblico ministero, quando procede al compimento di atti di perquisizione o sequestro, chiede alla persona sottoposta alle indagini, che sia presente, se è assistita da un difensore di fiducia e, qualora ne sia priva, designa un difensore di ufficio a norma dell'articolo 97 comma 3.

2. Il difensore ha facoltà di assistere al compimento dell'atto, fermo quanto previsto dall'articolo 249.

3. Si applicano le disposizioni dell'articolo 364 comma 7.

Art. 366. Deposito degli atti cui hanno diritto di assistere i difensori.

1. Salvo quanto previsto da specifiche disposizioni, i verbali degli atti compiuti dal pubblico ministero e dalla polizia giudiziaria ai quali il difensore ha diritto di assistere, sono depositati nella segreteria del pubblico ministero entro il terzo giorno successivo al compimento dell'atto, con facoltà per il difensore di esaminarli ed estrarne copia nei cinque giorni successivi. Quando non è stato dato avviso del compimento dell'atto, al difensore è immediatamente notificato l'avviso di deposito e il termine decorre dal ricevimento della notificazione. Il difensore ha facoltà di esaminare le cose sequestrate ne luogo in cui esse si trovano e, se si tratta di documenti, di estrarne copia.

2. Il pubblico ministero con decreto motivato può disporre, per gravi motivi, che il deposito degli atti indicati nel comma 1 e l'esercizio della facoltà indicata nel terzo período dello stesso comma siano ritardati, senza pregiudizio di ogni altra attività del difensore, per non oltre trenta giorni. Contro il decreto del pubblico ministero la persona sottoposta ad indagini ed il difensore possono proporre opposizione al giudice, che provvede ai sensi dell'articolo 127.

Art. 367. Memorie e richieste dei difensori.

1. Nel corso delle indagini preliminari, i difensori hanno facoltà di presentare memorie e richieste scritte al pubblico ministero.

Art. 368. Provvedimenti del giudice sulla richiesta di seqüestro.

1. Quando, nel corso delle indagini preliminari, il pubblico ministero ritiene che non si debba disporre il sequestro richiesto dall'interessato, trasmette la richiesta con il suo parere, al giudice per le indagini preliminari.

Art. 369. Informazione di garanzia.

1. Solo quando deve compiere un atto al quale il difensore ha diritto di assistere, il pubblico ministero invia 
per posta, in piego chiuso raccomandato con ricevuta di ritorno, alla persona sottoposta alle indagini e alla persona offesa una informazione di garanzia con indicazione delle norme di legge che si assumono violate, della data e del luogo del fatto e con invito a esercitare la facoltà di nominare un difensore di fiducia.

2. Qualora ne ravvisi la necessità ovvero l'ufficio postale restituisca il piego per irreperibilità del destinatario, il pubblico ministero può disporre che l'informazione di garanzia sia notificata a norma dell'articolo 151.

Art. 369-bis. Informazione della persona sottoposta alle indagini sul diritto di difesa.

1. Al compimento del primo atto a cui il difensore ha diritto di assistere e, comunque, prima dell'invito a presentarsi per rendere l'interrogatorio ai sensi del combinato disposto degli articoli 375, comma 3, e 416, il pubblico ministero, a pena de nullità degli atti successivi, notifica alla persona sottoposta alle indagini la comunicazione della nomina del difensore d'ufficio.

2. La comunicazione di cui al comma 1 deve contenere:

a) l'informazione della obbligatorietà della difesa técnica nel processo penale, com l'indicazione della facoltà e dei diritti attribuiti dalla legge alla persona sottoposta alle indagini;

b) il nominativo del difensore d'ufficio e il suo indirizzo e recapito telefonico;

c) l'indicazione della facoltà di nominare un difensore di fidúcia con l'avvertimento che, in mancanza, l'indagato sarà assistito da quello nominato d'ufficio;

d) l'indicazione dell'obbligo di retribuire il difensore d'ufficio ove non sussistano le condizioni per accedere al beneficio di cui alla lettera e e l'avvertimento che, in caso de insolvenza, si procederà ad esecuzione forzata;

e) l’indicazione delle condizioni per l'ammissione al patrocínio a spese dello Stato.

Art. 370. Atti diretti e atti delegati.

1. Il pubblico ministero compie personalmente ogni attività di indagine. Può avvalersi della polizia giudiziaria per il compimento di attività di indagine e di atti specificamente delegati, ivi compresi gli interrogatori ed i confronti cui partecipi la persona sottoposta alle indagini che si trovi in stato di libertà, con l'assistenza necessaria del difensore.

2. Quando procede a norma del comma 1, la polizia giudiziaria osserva le disposizioni degli articoli 364, 365 e 373.

3. Per singoli atti da assumere nella circoscrizione di altro tribunale, il pubblico ministero, qualora non ritenga di procedere personalmente, può delegare, secondo la rispettiva competenza per materia, il pubblico ministero presso il tribunale del luogo.

4. Quando ricorrono ragioni di urgenza o altri gravi motivi, il pubblico ministero delegato a norma del comma 3 ha facoltà di procedere di propria iniziativa anche agli atti che a seguito dello svolgimento di quelli specificamente delegati appaiono necessari ai fini delle indagini.

Art. 371. Rapporti tra diversi uffici del pubblico ministero.

1. Gli uffici diversi del pubblico ministero che procedono a indagini collegate, si coordinano tra loro per la speditezza, economia ed efficacia delle indagini medesime. A tali fini provvedono allo scambio di atti e di informazioni nonché alla comunicazione delle direttive rispettivamente impartite alla polizia giudiziaria. Possono altresì procedere, congiuntamente, al compimento di specifici atti.

2. Le indagini di uffici diversi del pubblico ministero si considerano collegate:

a) se i procedimenti sono connessi a norma dell'articolo 12;

b) se si tratta di reati dei quali gli uni sono stati commessi in occasione degli altri, o per conseguirne o assicurarne al colpevole o ad altri il profitto, il prezzo, il prodotto o l'impunità, o che sono stati commessi da più persone in danno reciproco le une delle altre, ovvero se la prova di un reato o di una sua circostanza influisce sulla prova di un altro reato o di un'altra circostanza;

c) se la prova di più reati deriva, anche in parte, dalla stessa fonte.

3. Salvo quanto disposto dall'articolo 12, il collegamento delle indagini non ha effetto sulla competenza.

Art. 371-bis. Attività di coordinamento del procuratore nazionale antimafia. 1. Il procuratore nazionale antimafia esercita le sue funzioni in relazione ai procedimenti per i delitti indicati 
nell'articolo 51 comma 3 bis e in relazione ai procedimenti di prevenzione. A tal fine dispone della direzione investigativa antimafia e dei servizi centrali e interprovinciali delle forze di polizia e impartisce direttive intese a regolarne l’impiego a fini investigativi.

2. Il procuratore nazionale antimafia esercita funzioni di impulso nei confronti dei procuratori distrettuali al fine di rendere effettivo il coordinamento delle attività di indagine, di garantire la funzionalità dell'impiego della polizia giudiziaria nelle sue diverse articolazioni e di assicurare la completezza e tempestività delle investigazioni.

3. Per lo svolgimento delle funzioni attribuitegli dalla legge, il procuratore nazionale antimafia, in particolare:

a) d'intesa con i procuratori distrettuali interessati, assicura il collegamento investigativo anche per mezzo dei magistrati della Direzione nazionale antimafia;

b) cura, mediante applicazioni temporanee dei magistrati della Direzione nazionale e delle direzioni distrettuali antimafia, la necessaria flessibilità e mobilità che soddisfino specifiche e contingenti esigenze investigative o processuali;

c) ai fini del coordinamento investigativo e della repressione dei reati provvede all'acquisizione e all'elaborazione di notizie, informazioni e dati attinenti alla criminalità organizzata;

d) soppressa;

e) soppressa;

f) impartisce ai procuratori distrettuali specifiche direttive alle quali attenersi per prevenire o risolvere contrasti riguardanti le modalità secondo le quali realizzare il coordinamento nell'attività di indagine;

g) riunisce i procuratori distrettuali interessati al fine di risolvere i contrasti che, malgrado le direttive specifiche impartite, sono insorti e hanno impedito di promuovere o di rendere effettivo il coordinamento;

h) dispone con decreto motivato, reclamabile al procuratore generale presso la Corte di Cassazione, l'avocazione delle indagini preliminari relative a taluno dei delitti indicati nell'articolo 51 comma 3-bis quando non hanno dato esito le riunioni disposte al fine di promuovere o rendere effettivo il coordinamento e questo non è stato possibile a causa della:

1) perdurante e ingiustificata inerzia nella attività di indagine;

2) ingiustificata e reiterata violazione dei doveri previsti dall'articolo 371 ai fini del coordinamento delle indagini;

3) soppresso;

4. Il procuratore nazionale antimafia provvede alla avocazione dopo aver assunto sul luogo le necessarie informazioni personalmente o tramite un magistrato della Direzione nazionale antimafia all'uopo designato. Salvi casi particolari, il procuratore nazionale antimafia o il magistrato da lui designato non puó delegare per il compimento degli atti di indagine altri uffici del pubblico ministero.

Art. 372. Avocazione delle indagini.

1. Il procuratore generale presso la corte di appello dispone con decreto motivato, e assunte, quando occorre, le necessarie informazioni, l'avocazione delle indagini preliminari quando:

a) in conseguenza dell'astensione o della incompatibilità del magistrato designato non è possibile provvedere alla sua tempestiva sostituzione;

b) il capo dell'ufficio del pubblico ministero ha omesso di provvedere alla tempestiva sostituzione del magistrato designato per le indagini nei casi previsti dall'articolo 36 comma 1 lett. a, b, d, e.

1-bis. Il procuratore generale presso la corte di appello, assunte le necessarie informazioni, dispone altresì con decreto motivato l'avocazione delle indagini preliminari relative ai delitti previsti dagli articoli 270-bis, 280, 285, 286, 289-bis, 305, 306, 416 nei casi in cui è obbligatorio l'arresto in flagranza e 422 c.p. quando, trattandosi di indagini collegate, non risulta effettivo il coordinamento delle indagini previste dall'articolo 371 comma 1 e non hanno dato esito le riunioni per il coordinamento disposte o promosse dal procuratore generale anche d'intesa con altri procuratori generali interessati.

Art. 373. Documentazione degli atti. 
1. Salvo quanto disposto in relazione a specifici atti è redatto verbale:

a) delle denunce, querele e istanze di procedimento presentate oralmente;

b) degli interrogatori e dei confronti con la persona sottoposta alle indagini;

c) delle ispezioni, delle perquisizioni e dei sequestri;

d) delle sommarie informazioni assunte a norma dell'articolo 362;

d-bis) dell'interrogatorio assunto a norma dell'articolo 363;

e) degli accertamenti tecnici compiuti a norma dell'articolo 360 .

2. Il verbale è redatto secondo le modalità previste nel titolo III del libro II.

3. Alla documentazione delle attività di indagine preliminare, diverse da quelle previste dal comma 1 , si procede soltanto mediante la redazione del verbale in forma riassuntiva ovvero, quando si tratta di atti a contenuto semplice o di limitata rilevanza, mediante le annotazioni ritenute necessarie.

4. Gli atti sono documentati nel corso del loro compimento ovvero immediatamente dopo quando ricorrono insuperabili circostanze, da indicarsi specificamente, che impediscono la documentazione contestuale.

5. L'atto contenente la notizia di reato e la documentazione relativa alle indagini sono conservati in apposito fascicolo presso l'ufficio del pubblico ministero assieme agli atti trasmessi dalla polizia giudiziaria a norma dell'articolo 357.

6. Alla redazione del verbale e delle annotazioni provvede l'ufficiale di polizia giudiziaria o l'ausiliario che assiste il pubblico ministero. Si applica la disposizione dell'articolo 142.

Art. 374. Presentazione spontanea.

1. Chi ha notizia che nei suoi confronti sono svolte indagini, ha facoltà di presentarsi al pubblico ministero e di rilasciare dichiarazioni.

2. Quando il fatto per cui si procede è contestato a chi si presenta spontaneamente e questi è ammesso a esporre le sue discolpe, l'atto così compiuto equivale per ogni effetto all'interrogatorio. In tale ipotesi, si applicano le disposizioni previste dagli articoli 64, 65 e 364.

3. La presentazione spontanea non pregiudica l'applicazione di misure cautelari.

Art. 375. Invito a presentarsi.

1. Il pubblico ministero invita la persona sottoposta alle indagini a presentarsi quando deve procedere ad atti che ne richiedono la presenza.

2. L'invito a presentarsi contiene:

a) le generalità o le altre indicazioni personali che valgono a identificare la persona sottoposta alle indagini;

b) il giorno, l'ora e il luogo della presentazione nonché l'autorità davanti alla quale la persona deve presentarsi;

c) il tipo di atto per il quale l'invito è predisposto;

d) l'avvertimento che il pubblico ministero potrà disporre a norma dell'articolo 132 l'accompagnamento coattivo in caso di mancata presentazione senza che sia stato addotto legittimo impedimento.

3. Quando la persona è chiamata a rendere l'interrogatorio, l'invito contiene altresì la sommaria enunciazione del fatto quale risulta dalle indagini fino a quel momento compiute. L'invito può inoltre contenere, ai fini di quanto previsto dall'articolo 453 comma 1, l'indicazione degli elementi e delle fonti di prova e l'avvertimento che potrà essere presentata richiesta di giudizio immediato.

4. L'invito a presentarsi è notificato almeno tre giorni prima di quello fissato per la comparizione, salvo che, per ragioni di urgenza, il pubblico ministero ritenga di abbreviare il termine, purchè sia lasciato il tempo necessario per comparire.

Art. 376. Accompagnamento coattivo per procedere a interrogatorio o a confronto.

1. Quando si tratta di procedere ad atti di interrogatorio o confronto, l'accompagnamento coattivo è disposto dal pubblico ministero su autorizzazione del giudice. 
Art. 377. Citazioni di persone informate sui fatti.

1. Il pubblico ministero può emettere decreto di citazione quando deve procedere ad atti che richiedono la presenza della persona offesa e delle persone in grado di riferire su circostanze utili ai fini delle indagini.

2. Il decreto contiene:

a) le generalità della persona;

b) il giorno, l'ora e il luogo della comparizione nonché l'autorità davanti alla quale la persona deve presentarsi;

c) l'avvertimento che il pubblico ministero potrà disporre a norma dell'articolo 133 l'accompagnamento coattivo in caso di mancata comparizione senza che sia stato addotto legittimo impedimento.

3. Il pubblico ministero provvede allo stesso modo per la citazione del consulente tecnico, dell'interprete e del custode delle cose sequestrate.

Art. 378. Poteri coercitivi del pubblico ministero.

1. Il pubblico ministero ha, nell'esercizio delle sue funzioni, i poteri indicati nell'articolo 131.

Titolo VI: Arresto in flagranza e fermo

Art. 379. Determinazione della pena.

1. Agli effetti delle disposizioni di questo titolo, la pena è determinata a norma dell'articolo 278 .

Art. 380. Arresto obbligatorio in flagranza.

1. Gli ufficiali e gli agenti di polizia giudiziaria procedono all'arresto di chiunque è colto in flagranza di un delitto non colposo, consumato o tentato, per il quale la legge stabilisce la pena dell'ergastolo o della reclusione non inferiore nel minimo a cinque anni e nel massimo a venti anni.

2. Anche fuori dei casi previsti dal comma 1, gli ufficiali e gli agenti di polizia giudiziaria procedono all'arresto di chiunque è colto in flagranza di uno dei seguenti delitti non colposi, consumati o tentati:

a) delitti contro la personalità dello Stato previsti nel titolo I del libro II del Codice Penale per i quali è stabilita la pena della reclusione non inferiore nel minimo a cinque anni o nel massimo a dieci anni;

b) delitto di devastazione e saccheggio previsto dall'articolo 419 c.p.;

c) delitti contro l'incolumità pubblica previsti nel titolo VI del libro II del Codice Penale per i quali è stabilita la pena della reclusione non inferiore nel minimo a tre anni o nel massimo a dieci anni;

d) delitto di riduzione in schiavitù previsto dall'articolo 600 delitto di prostituzione minorile previsto dall'articolo 600-bis, primo comma, delitto di pornografia minorile previsto dall'articolo 600-ter, commi primo e secondo, anche se relativo al materiale pornográfico di cui all'articolo 600-quater.1, e delitto di iniziative turistiche volte allo sfruttamento della prostituzione minorile previsto dall'articolo 600-quinquies c.p.;

e) delitto di furto, quando ricorre la circostanza aggravante prevista dall'articolo 4 della L. 8 agosto 1977 n. 533 quella prevista dall'articolo 625, primo comma, numero 2, prima ipotesi, del codice penale, savlo che, in quest'ultimo caso, ricorra la circostanza attenuante di cui all'articolo 62, primo comma, numero 4, del codice penale;

e-bis) delitti di furto previsti dall'articolo 624-bis del codice penale, salvo che ricorra la circostanza attenuante di cui all'articolo 62, primo comma, numero 4, del códice penale;

f) delitto di rapina previsto dall'articolo 628 c.p. e di estorsione previsto dall'articolo 629 c.p.;

g) delitti di illegale fabbricazione, introduzione nello Stato, messa in vendita, cessione, detenzione e porto in luogo pubblico o aperto al pubblico di armi da guerra o tipo guerra o parti di esse, di esplosivi, di armi clandestine nonché di più armi comuni da sparo escluse quelle previste dall'articolo 2, comma terzo, della L. 18 aprile 1975, n. 110; 
h) delitti concernenti sostanze stupefacenti o psicotrope puniti a norma dell'articolo 73 del testo unico approvato con D.P.R. 9 ottobre 1990, n. 309, salvo che ricorra la circostanza prevista dal comma 5 del medesimo articolo;

i) delitti commessi per finalità di terrorismo o di eversione dell'ordine costituzionale per i quali la legge stabilisce la pena della reclusione non inferiore nel minimo a quattro anni o nel massimo a dieci anni;

l) delitti di promozione, costituzione, direzione e organizzazione delle associazioni segrete previste dall'articolo 1 della L. 25 gennaio 1982 n. 17, delle associazioni di carattere militare previste dall'articolo 1 della L. 17 aprile 1956 n. 561, delle associazioni dei movimenti o dei gruppi previsti dagli articoli 1 e 2 della L. 20 giugno 1952 n. 645, delle organizzazioni, associazioni, movimenti o gruppi di cui all'articoli 3, comma 3 della L. 13 ottobre 1975, n. 654;

l-bis) delitti di partecipazione, promozione, direzione e organizzazione della associazione di tipo mafioso prevista dall'articolo 416 bis c.p.;

m) delitti di promozione, direzione, costituzione e organizzazione della associazione per delinquere prevista dall'articolo 416 commi 1 e 3 c.p., se l'associazione è diretta alla commissione di più delitti fra quelli previsti dai comma $\mathrm{l}$ o dalle lettere a, b, c d, f, g, i del presente comma.

3. Se si tratta di delitto perseguibile a querela, l'arresto in flagranza è eseguito se la querela viene proposta, anche con dichiarazione resa oralmente all'ufficiale o all'agente di polizia giudiziaria presente nel luogo. Se l'avente diritto dichiara di rimettere la querela, l'arrestato è posto immediatamente in libertà.

Art. 381. Arresto facoltativo in flagranza.

1. Gli ufficiali e gli agenti di polizia giudiziaria hanno facoltà di arrestare chiunque è colto in flagranza di un delitto non colposo, consumato o tentato, per il quale la legge stabilisce la pena della reclusione superiore nel massimo a tre anni ovvero di un delitto colposo per il quale la legge stabilisce la pena della reclusione non inferiore nel massimo a cinque anni.

2. Gli ufficiali e gli agenti di polizia giudiziaria hanno altresì facoltà di arrestare chiunque è colto in flagranza di uno dei seguenti delitti:

a) peculato mediante profitto dell'errore altrui previsto dall'articolo 316 c.p.;

b) corruzione per un atto contrario ai doveri d'ufficio prevista dagli articoli 319 (comma 4) e 321 c.p.;

c) violenza o minaccia a un pubblico ufficiale prevista dall'articolo 336 comma 2 c.p.;

d) commercio e somministrazione di medicina guasti e di sostanze alimentari nocive previsti dagli articoli 443 e 444 c.p.;

e) corruzione di minorenni prevista dall'articolo 530 c.p.;

f) lesione personale prevista dall'articolo 582 c.p.;

g) furto previsto dall'articolo 624 c.p.;

h) danneggiamento aggravato a norma dell'articolo 635 comma 2 c.p.;

i) truffa prevista dall'articolo 640 c.p.;

1) appropriazione indebita prevista dall'articolo 646 c.p.;

l-bis) offerta, cessione o detenzione di materiale pornografico previste degli articoli 600-ter, quarto comma, e 600-quater del codice penale, anche se relative al materiale pornográfico di cui all'articolo 600-quater.1 del medesimo codice;

m) alterazione di armi e fabbricazione di esplosivi non riconosciuti previste dagli articoli 3 e 24 comma 1 della L. 18 aprile 1975 n. 110;

m-bis) fabbricazione, detenzione o uso di documento di identificazione falso previsti dall'articolo 497-bis del codice penale;

m-ter) falsa attestazione o dichiarazione a un pubblico ufficiale sullla identità o su qualità personali, proprie o di altri, prevista dall'articolo 495 del codice penale;

m-quater) fraudolente alterazioni per impedire l'identificazione o l'accertamento di qualità personali, previste 
dall'articolo 495-ter del codice penale.

3. Se si tratta di delitto perseguibile a querela, l'arresto in flagranza può essere eseguito se la querela viene proposta, anche con dichiarazione resa oralmente all'ufficiale o all'agente di polizia giudiziaria presente nel luogo. Se l'avente diritto dichiara di rimettere la querela, l'arrestato è posto immediatamente in libertà.

4. Nelle ipotesi previste dal presente articolo si procede all'arresto in flagranza soltanto se la misura è giustificata dalla gravità del fatto ovvero dalla pericolosità del soggetto desunta dalla sua personalità o dalle circostanze del fatto.

4-bis. Non è consentito l'arresto della persona richiesta di fornire informazioni dalla polizia giudiziaria o dal pubblico ministero per reati concernenti il contenuto delle informazioni o il rifiuto di fornirle.

Art. 382. Stato di flagranza.

1. E' in stato di flagranza chi viene colto nell'atto di commettere il reato ovvero chi, subito dopo il reato, è inseguito dalla polizia giudiziaria, dalla persona offesa o da altre persone ovvero è sorpreso con cose o tracce dalle quali appaia che egli abbia commesso il reato immediatamente prima.

2. Nel reato permanente lo stato di flagranza dura fino a quando non è cessata la permanenza.

Art. 383. Facoltà di arresto da parte dei privati.

1. Nei casi previsti dall'art. 380 ogni persona è autorizzata a procedere all'arresto in flagranza, quando si tratta di delitti perseguibili di ufficio.

2. La persona che ha eseguito l'arresto deve senza ritardo consegnare l'arrestato e le cose costituenti il corpo del reato alla polizia giudiziaria la quale redige il verbale della consegna e ne rilascia copia.

Art. 384. Fermo di indiziato di delitto.

1. Anche fuori dei casi di flagranza, quando sussistono specifici elementi che, anche in relazione alla impossibilita di identificare l'indiziato, fanno ritenere fondato il pericolo di fuga, il pubblico ministero dispone il fermo della persona gravemente indiziata di un delitto per il quale la legge stabilisce la pena dell'ergastolo o della reclusione non inferiore nel minimo a due anni e superiore nel massimo a sei anni ovvero di un delitto concernente le armi da guerra e gli esplosivi o di um delitto commesso per finalità di terrorismo, anche internazionale o di eversione dell'ordine democratico.

2. Nei casi previsti dal comma 1 e prima che il pubblico ministero abbia assunto la direzione delle indagini, gli ufficiali e gli agenti di polizia giudiziaria procedono al fermo di propria iniziativa.

3. La polizia giudiziaria procede inoltre al fermo di propria iniziativa qualora sia successivamente individuato l'indiziato ovvero sopravvengano specifici elementi, quali il possesso di documenti falsi, che rendano fondato il pericolo che l'indiziato sia per darsi alla fuga e non sia possibile, per la situazione di urgenza, attendere il provvedimento del pubblico ministero.

Art. 385. Divieto di arresto o di fermo in determinate circostanze.

1. L'arresto o il fermo non è consentito quando, tenuto conto delle circostanze del fatto, appare che questo è stato compiuto nell'adempimento di un dovere o nell'esercizio di una facoltà legittima ovvero in presenza di una causa di non punibilità.

Art. 386. Doveri della polizia giudiziaria in caso di arresto o di fermo.

1. Gli ufficiali e gli agenti di polizia giudiziaria che hanno eseguito l'arresto o il fermo o hanno avuto in consegna l'arrestato, ne danno immediata notizia al pubblico ministero del luogo dove l'arresto o il fermo è stato eseguito. Avvertono inoltre l'arrestato o il fermato della facoltà di nominare un difensore di fiducia.

2. Dell'avvenuto arresto o fermo gli ufficiali e gli agenti di polizia giudiziaria informano immediatamente il difensore di fiducia eventualmente nominato ovvero quello di ufficio designato dal pubblico ministero a norma dell'articolo 97.

3. Qualora non ricorra l'ipotesi prevista dall'articolo 389 comma 2, gli ufficiali e gli agenti di polizia giudiziaria pongono l'arrestato o il fermato a disposizione del pubblico ministero al più presto e comunque non oltre ventiquattro ore dall'arresto o dal fermo. Entro il medesimo termine trasmettono il relativo verbale, salvo che il pubblico ministero autorizzi una dilazione maggiore. Il verbale contiene l'eventuale nomina del difensore di fiducia, l'indicazione del giorno, dell'ora e del luogo in cui l'arresto o il fermo è stato eseguito e l'enunciazione delle ragioni che lo hanno determinato. 
4. Gli ufficiali e gli agenti di polizia giudiziaria pongono l'arrestato o il fermato a disposizione del pubblico ministero mediante la conduzione nella casa circondariale o mandamentale del luogo dove l'arresto o il fermo è stato eseguito.

5. Il pubblico ministero può disporre che l'arrestato o il fermato sia custodito, in uno dei luoghi indicati nel comma 1 dell'articolo 284 ovvero, se ne possa derivare grave pregiudizio per le indagini, presso altra casa circondariale o mandamentale.

6. Gli ufficiali e gli agenti di polizia giudiziaria trasmettono il verbale di fermo anche al pubblico ministero che lo ha disposto, se diverso da quello indicato nel comma 1.

7. L'arresto o il fermo diviene inefficace se non sono osservati i termini previsti dal comma 3.

Art. 387. Avviso dell'arresto o del fermo ai familiari.

1. La polizia giudiziaria, con il consenso dell'arrestato o del fermato, deve senza ritardo dare notizia ai familiari dell'avvenuto arresto o fermo.

Art. 388. Interrogatorio dell'arrestato o del fermato.

1. Il pubblico ministero può procedere all'interrogatorio dell'arrestato o del fermato, dandone tempestivo avviso al difensore di fiducia ovvero, in mancanza, al difensore di ufficio.

2. Durante l'interrogatorio, osservate le forme previste dall'articolo 64, il pubblico ministero informa l'arrestato o il fermato del fatto per cui si procede e delle ragioni che hanno determinato il provvedimento comunicandogli inoltre gli elementi a suo carico e, se non può derivarne pregiudizio per le indagini, le fonti.

Art. 389. Casi di immediata liberazione dell'arrestato o del fermato.

1. Se risulta evidente che l'arresto o il fermo è stato eseguito per errore di persona o fuori dei casi previsti dalla legge o se la misura dell'arresto o del fermo è divenuta inefficace a norma degli articoli 386 comma 7 e 390 comma 3, il pubblico ministero dispone con decreto motivato che l'arrestato o il fermato sia posto immediatamente in libertà.

2. La liberazione è altresì disposta prima dell'intervento del pubblico ministero dallo stesso ufficiale di polizia giudiziaria, che ne informa subito il pubblico ministero del luogo dove l'arresto o il fermo è stato eseguito.

Art. 390. Richiesta di convalida dell'arresto o del fermo.

1. Entro quarantotto ore dall'arresto o dal fermo il pubblico ministero, qualora non debba ordinare la immediata liberazione dell'arrestato o del fermato, richiede la convalida al giudice per le indagini preliminari competente in relazione al luogo dove l'arresto o il fermo è stato eseguito.

2. Il giudice fissa l'udienza di convalida al più presto e comunque entro le quarantotto ore successive dandone avviso, senza ritardo, al pubblico ministero e al difensore.

3. L'arresto o il fermo diviene inefficace se il pubblico ministero non osserva le prescrizioni del comma 1.

3-bis. Se non ritiene di comparire, il pubblico ministero trasmette al giudice, per l'udienza di convalida, le richieste in ordine alla libertà personale con gli elementi su cui le stesse si fondano.

Art. 391. Udienza di convalida.

1. L'udienza di convalida si svolge in camera di consiglio con la partecipazione necessaria del difensore dell'arrestato o del fermato.

2. Se il difensore di fiducia o di ufficio non è stato reperito o non è comparso, il giudice provvede a norma dell'articolo 97 comma 4.

3. Il pubblico ministero, se comparso, indica i motivi dell'arresto o del fermo e illustra le richieste in ordine alla libertà personale. Il giudice procede quindi all'interrogatorio dell'arrestato o del fermato, salvo che questi non abbia potuto o si sia rifiutato di comparire; sente in ogni caso il suo difensore.

4. Quando risulta che l'arresto o il fermo è stato legittimamente eseguito e sono stati osservati i termini previsti dagli articoli 386 comma 3 e 390 comma 1, il giudice provvede alla convalida con ordinanza. Contro l'ordinanza che decide sulla convalida, il pubblico ministero e l'arrestato o il fermato possono proporre ricorso per cassazione.

5. Se ricorrono le condizioni di applicabilità previste dall'articolo 273 e taluna delle esigenze cautelari 
previste dall'articolo 274, il giudice dispone l'applicazione di una misura coercitiva a norma dell'articolo 291. Quando l'arresto è stato eseguito per uno dei delitti indicati nell'articolo 381 comma 2, ovvero per uno dei delitti per i quali è consentito anche fuori daí casi di flagranza, l'applicazione della misura è disposta anche al di fuori dei limiti di pena previsti dagli articoli 274, comma 1, lettera c, e 280.

6. Quando non provvede a norma del comma 5, il giudice dispone con ordinanza la immediata liberazione dell'arrestato o del fermato.

7. Le ordinanze previste dai commi precedenti, se non sono pronunciate in udienza, sono comunicate o notificate a coloro che hanno diritto di proporre impugnazione. Le ordinanze pronunciate in udienza sono comunicate al pubblico ministero e notificate all'arrestato o al fermato se non comparsi. I termini per l'impugnazione decorrono dalla lettura del provvedimento in udienza ovvero dalla sua comunicazione o notificazione. L'arresto o il fermo cessa di avere efficacia se l'ordinanza di convalida non è pronunciata o depositata nelle quarantotto ore successive al momento in cui l'arrestato o il fermato è stato posto a disposizione del giudice.

Titolo VI-bis: Investigazioni difensive

Art. 391-bis. Colloquio, ricezione di dichiarazioni e assunzione di informazioni da parte del difensore.

1. Salve le incompatibilità previste dall'articolo 197, comma 1, lettere c e d, per acquisire notizie il difensore, il sostituto, gli investigatori privati autorizzati o i consulenti tecnici possono conferire con le persone in grado di riferire circostanze utili ai fini dell'attività investigativa. In questo caso, l'acquisizione delle notizie avviene attraverso un colloquio non documentato.

2. Il difensore o il sostituto possono inoltre chiedere alle persone di cui al comma 1 una dichiarazione scritta ovvero di rendere informazioni da documentare secondo le modalità previste dall'articolo 391-ter.

3. In ogni caso, il difensore, il sostituto, gli investigatori privati autorizzati o i consulenti tecnici avvertono le persone indicate nel comma 1 :

a) della propria qualità e dello scopo del colloquio;

b) se intendono semplicemente conferire ovvero ricevere dichiarazioni o assumere informazioni indicando, in tal caso, le modalità e la forma di documentazione;

c) dell'obbligo di dichiarare se sono sottoposte ad indagini o imputate nello stesso procedimento, in un procedimento connesso o per un reato collegato;

d) della facoltà di non rispondere o di non rendere la dichiarazione;

e) del divieto di rivelare le domande eventualmente formulate dalla polizia giudiziaria o dal pubblico ministero e le risposte date;

f) delle responsabilità penali conseguenti alla falsa dichiarazione.

4. Alle persone già sentite dalla polizia giudiziaria o dal pubblico ministero non possono essere richieste notizie sulle domande formulate o sulle risposte date.

5. Per conferire, ricevere dichiarazioni o assumere informazioni da una persona sottoposta ad indagini o imputata nello stesso procedimento, in un procedimento connesso o per un reato collegato, è dato avviso, almeno ventiquattro ore prima, al suo difensore la cui presenza è necessaria. Se la persona è priva di difensore, il giudice, su richiesta del difensore che procede alle investigazioni, dispone la nomina di un difensore di ufficio ai sensi dell'articolo 97.

6. Le dichiarazioni ricevute e le informazioni assunte in violazione di una delle disposizioni di cui ai commi precedenti non possono essere utilizzate. La violazione di tali disposizioni costituisce illecito disciplinare ed è comunicata dal giudice che procede all'organo titolare del potere disciplinare.

7. Per conferire, ricevere dichiarazioni o assumere informazioni da persona detenuta, il difensore deve munirsi di specifica autorizzazione del giudice che procede nei confronti della stessa, sentiti il suo difensore ed il pubblico ministero. Prima dell'esercizio dell'azione penale l'autorizzazione è data dal giudice per le indagini preliminari. Durante l'esecuzione della pena provvede il magistrato di sorveglianza. 
8. All'assunzione di informazioni non possono assistere la persona sottoposta alle indagini, la persona offesa e le altre parti private.

9. Il difensore o il sostituto interrompono l'assunzione di informazioni da parte della persona non imputata ovvero della persona non sottoposta ad indagini, qualora essa renda dichiarazioni dalle quali emergano indizi di reità a suo carico. Le precedenti dichiarazioni non possono essere utilizzate contro la persona che le ha rese.

10. Quando la persona in grado di riferire circostanze utili ai fini dell'attività investigativa abbia esercitato la facoltà di cui alla lettera d del comma 3 , il pubblico ministero, su richiesta del difensore, ne dispone l'audizione che fissa entro sette giorni dalla richiesta medesima. Tale disposizione non si applica nei confronti delle persone sottoposte ad indagini o imputate nello stesso procedimento e nei confronti delle persone sottoposte ad indagini o imputate in un diverso procedimento nelle ipotesi previste dall'articolo 210. L'audizione si svolge alla presenza del difensore che per primo formula le domande. Anche con riferimento alle informazioni richieste dal difensore si applicano le disposizioni dell'articolo 362.

11. Il difensore, in alternativa all'audizione di cui al comma 10, può chiedere che si proceda con incidente probatorio all'assunzione della testimonianza o all'esame della persona che abbia esercitato la facoltà di cui alla lettera d del comma 3, anche al di fuori delle ipotesi previste dall'articolo 392, comma 1.

Art. 391-ter. Documentazione delle dichiarazioni e delle informazioni.

1. La dichiarazione di cui al comma 2 dell'articolo 391-bis, sottoscritta dal dichiarante, è autenticata dal difensore o da un suo sostituto, che redige una relazione nella quale sono riportati:

a) la data in cui ha ricevuto la dichiarazione;

b) le proprie generalità e quelle della persona che ha rilasciato la dichiarazione;

c) l'attestazione di avere rivolto gli avvertimenti previsti dal comma 3 dell'articolo 391-bis;

d) i fatti sui quali verte la dichiarazione.

2. La dichiarazione è allegata alla relazione.

3. Le informazioni di cui al comma 2 dell'articolo 391-bis sono documentate dal difensore o da un suo sostituto che possono avvalersi per la materiale redazione del verbale di persone di loro fiducia. Si osservano le disposizioni contenute nel titolo III del libro secondo, in quanto applicabili.

Art. 391-quater. Richiesta di documentazione alla pubblica amministrazione.

1. Ai fini delle indagini difensive, il difensore può chiedere i documenti in possesso della pubblica amministrazione e di estrarne copia a sue spese.

2. L'istanza deve essere rivolta all'amministrazione che ha formato il documento o lo detiene stabilmente.

3. In caso di rifiuto da parte della pubblica amministrazione si applicano le disposizioni degli articoli 367 e 368.

Art. 391-quinquies. Potere di segretazione del pubblico ministero.

1. Se sussistono specifiche esigenze attinenti all'attività di indagine, il pubblico ministero può, con decreto motivato, vietare alle persone sentite di comunicare i fatti e le circostanze oggetto dell'indagine di cui hanno conoscenza. Il divieto non può avere una durata superiore a due mesi.

2. Il pubblico ministero, nel comunicare il divieto di cui al comma 1 alle persone che hanno rilasciato le dichiarazioni, le avverte delle responsabilità penali conseguenti all'indebita rivelazione delle notizie.

Art. 391-sexies. Accesso ai luoghi e documentazione.

1. Quando effettuano un accesso per prendere visione dello stato dei luoghi e delle cose ovvero per procedere alla loro descrizione o per eseguire rilievi tecnici, grafici, planimetrici, fotografici o audiovisivi, il difensore, il sostituto e gli ausiliari indicati nell'articolo 391-bis possono redigere un verbale nel quale sono riportati:

a) la data ed il luogo dell'accesso;

b) le proprie generalità e quelle delle persone intervenute;

c) la descrizione dello stato dei luoghi e delle cose; 
d) l'indicazione degli eventuali rilievi tecnici, grafici, planimetrici, fotografici o audiovisivi eseguiti, che fanno parte integrante dell'atto e sono allegati al medesimo. Il verbale è sottoscritto dalle persone intervenute.

Art. 391-septies. Accesso ai luoghi privati o non aperti al pubblico.

1. Se è necessario accedere a luoghi privati o non aperti al pubblico e non vi è il consenso di chi ne ha la disponibilità, l'accesso, su richiesta del difensore, è autorizzato dal giudice, con decreto motivato che ne specifica le concrete modalità.

2. Nel caso di cui al comma 1 , la persona presente è avvertita della facoltà di farsi assistere da persona di fiducia, purché questa sia prontamente reperibile e idonea a norma dell'articolo 120.

3. Non è consentito l'accesso ai luoghi di abitazione e loro pertinenze, salvo che sia necessario accertare le tracce e gli altri effetti materiali del reato.

Art. 391-octies. Fascicolo del difensore.

1. Nel corso delle indagini preliminari e nell'udienza preliminare, quando il giudice deve adottare una decisione con l'intervento della parte privata, il difensore può presentargli direttamente gli elementi di prova a favore del proprio assistito.

2. Nel corso delle indagini preliminari il difensore che abbia conoscenza di un procedimento penale può presentare gli elementi difensivi di cui al comma 1 direttamente al giudice, perché ne tenga conto anche nel caso in cui debba adottare una decisione per la quale non è previsto l'intervento della parte assistita.

3. La documentazione di cui ai commi 1 e 2, in originale o, se il difensore ne richiede la restituzione, in copia, è inserita nel fascicolo del difensore, che è formato e conservato presso l'ufficio del giudice per le indagini preliminari. Della documentazione il pubblico ministero può prendere visione ed estrarre copia prima che venga adottata una decisione su richiesta delle altre parti o con il loro intervento. Dopo la chiusura delle indagini preliminari il fascicolo del difensore è inserito nel fascicolo di cui all'articolo 433.

4. Il difensore può, in ogni caso, presentare al pubblico ministero gli elementi di prova a favore del proprio assistito.

Art. 391-nonies. Attività investigativa preventiva.

1. L'attività investigativa prevista all'articolo 327-bis, con esclusione degli atti che richiedono l'autorizzazione o l'intervento dell'autorità giudiziaria, può essere svolta anche dal difensore che ha ricevuto apposito mandato per l'eventualità che si instauri un procedimento penale.

2. Il mandato è rilasciato con sottoscrizione autenticata e contiene la nomina del difensore e l'indicazione dei fatti ai quali si riferisce.

Art. 391-decies. Utilizzazione della documentazione delle investigazioni difensive.

1. Delle dichiarazioni inserite nel fascicolo del difensore le parti possono servirsi a norma degli articoli 500 , 512 e 513.

2. Fuori del caso in cui è applicabile l'articolo 234, la documentazione di atti non ripetibili compiuti in occasione dell'accesso ai luoghi, presentata nel corso delle indagini preliminari o nell'udienza preliminare, è inserita nel fascicolo previsto dall'articolo 431.

3. Quando si tratta di accertamenti tecnici non ripetibili, il difensore deve darne avviso, senza ritardo, al pubblico ministero per l'esercizio delle facoltà previste, in quanto compatibili, dall'articolo 360. Negli altri casi di atti non ripetibili di cui al comma 2, il pubblico ministero, personalmente o mediante delega alla polizia giudiziaria, ha facoltà di assistervi.

4. Il verbale degli accertamenti compiuti ai sensi del comma 3 e, quando il pubblico ministero ha esercitato la facoltà di assistervi, la documentazione degli atti compiuti ai sensi del comma 2 sono inseriti nel fascicolo del difensore e nel fascicolo del pubblico ministero. Si applica la disposizione di cui all'articolo 431, comma 1 , lettera c.

Titolo VII: Incidente probatorio 
Art. 392. Casi.

1. Nel corso delle indagini preliminari il pubblico ministero e la persona sottoposta alle indagini possono chiedere al giudice che si proceda con incidente probatorio:

a) all'assunzione della testimonianza di una persona, quando vi è fondato motivo di ritenere che la stessa non potrà essere esaminata nel dibattimento per infermità o altro grave impedimento;

b) all'assunzione di una testimonianza quando, per elementi concreti e specifici, vi è fondato motivo di ritenere che la persona sia esposta a violenza, minaccia, offerta o promessa di denaro o di altra utilità affinché non deponga o deponga il falso;

c) all'esame della persona sottoposta alle indagini su fatti concernenti la responsabilità di altri;

d) all'esame delle persone indicate nell'articolo 210;

e) al confronto tra persone che in altro incidente probatorio o al pubblico ministero hanno reso dichiarazioni discordanti, quando ricorre una delle circostanze previste dalle lettere a e b;

f) a una perizia o a un esperimento giudiziale, se la prova riguarda una persona, una cosa o un luogo il cui stato è soggetto a modificazione non evitabile;

g) a una ricognizione, quando particolari ragioni di urgenza non consentono di rinviare l'atto al dibattimento.

1-bis. Nei procedimenti per i delitti di cui agli articoli 600, 600-bis, 600-ter, anche se relativo al materiale pornográfico di cui all'articolo 600-quater.1, 600-quinquies, 601, 602, 609-bis, 609-ter, 609-quater, 609quinquies e 609-octies del codice penale il pubblico ministero o la persona sottoposta alle indagini possono chiedere che si proceda con incidente probatorio all'assunzione della testimonianza di persona minore degli anni sedici, anche al di fuori delle ipotesi previste dal comma 1.

2. Il pubblico ministero e la persona sottoposta alle indagini possono altresì chiedere una perizia che, se fosse disposta nel dibattimento, ne potrebbe determinare una sospensione superiore a sessanta giorni.

Art. 393. Richiesta.

1. La richiesta è presentata entro i termini per la conclusione delle indagini preliminari e comunque in tempo sufficiente per l'assunzione della prova prima della scadenza dei medesimi termini e indica:

a) la prova da assumere, i fatti che ne costituiscono l'oggetto e le ragioni della sua rilevanza per la decisione dibattimentale;

b) le persone nei confronti delle quali si procede per i fatti oggetto della prova;

c) le circostanze che, a norma dell'articolo 392, rendono la prova non rinviabile al dibattimento.

2. La richiesta proposta dal pubblico ministero indica anche i difensori delle persone interessate a norma del comma 1 lettera b, la persona offesa e il suo difensore.

2-bis. Con la richiesta di incidente probatorio di cui all'articolo 392, comma 1-bis, il pubblico ministero deposita tutti gli atti di indagine compiuti.

3. Le disposizioni dei commi 1 e 2 si osservano a pena di inammissibilità.

4. Il pubblico ministero e la persona sottoposta alle indagini possono chiedere la proroga del termine delle indagini preliminari ai fini dell'esecuzione dell'incidente probatorio. Il giudice provvede con decreto motivato, concedendo la proroga per il tempo indispensabile all'assunzione della prova quando risulta che la richiesta di incidente probatorio non avrebbe potuto essere formulata anteriormente. Nello stesso modo il giudice provvede se il termine per le indagini preliminari scade durante l'esecuzione dell'incidente probatorio. Del provvedimento è data in ogni caso comunicazione al procuratore generale presso la corte di appello.

Art. 394. Richiesta della persona offesa.

1. La persona offesa può chiedere al pubblico ministero di promuovere un incidente probatorio.

2. Se non accoglie la richiesta, il pubblico ministero pronuncia decreto motivato e lo fa notificare alla persona offesa.

Art. 395. Presentazione e notificazione della richiesta.

1. La richiesta di incidente probatorio è depositata nella cancelleria del giudice per le indagini preliminari, 
unitamente a eventuali cose o documenti, ed è notificata a cura di chi l'ha proposta, secondo i casi, al pubblico ministero e alle persone indicate nell'articolo 393 comma 1 lettera b. La prova della notificazione è depositata in cancelleria.

Art. 396. Deduzioni.

1. Entro due giorni dalla notificazione della richiesta, il pubblico ministero ovvero la persona sottoposta alle indagini può presentare deduzioni sull'ammissibilità e sulla fondatezza della richiesta, depositare cose, produrre documenti nonché indicare altri fatti che debbano costituire oggetto della prova e altre persone interessate a norma dell'articolo 393 comma 1 lettera b.

2. Copia delle deduzioni è consegnata dalla persona sottoposta alle indagini alla segreteria del pubblico ministero, che comunica senza ritardo al giudice le indicazioni necessarie per gli avvisi. La persona sottoposta alle indagini può prendere visione ed estrarre copia delle deduzioni da altri presentate.

Art. 397. Differimento dell'incidente probatório.

1. Il pubblico ministero può chiedere che il giudice disponga il differimento dell'incidente probatorio richiesto dalla persona sottoposta alle indagini quando la sua esecuzione pregiudicherebbe uno o più atti di indagine preliminare. Il differimento non è consentito quando pregiudicherebbe l'assunzione della prova.

2. La richiesta di differimento è presentata a pena di inammissibilità nella cancelleria del giudice entro il termine previsto dall'articolo 396, comma 1, e indica:

a) l'atto o gli atti di indagine preliminare che l'incidente probatorio pregiudicherebbe e le cause del pregiudizio;

b) il termine del differimento richiesto.

3. Il giudice, se non dichiara inammissibile o rigetta la richiesta di incidente probatorio, provvede entro due giorni con ordinanza con la quale accoglie, dichiara inammissibile o rigetta la richiesta di differimento. L'ordinanza di inammissibilità o di rigetto è immediatamente comunicata al pubblico ministero.

4. Nell'accogliere la richiesta di differimento il giudice fissa l'udienza per l'incidente probatório, non oltre il termine strettamente necessario al compimento dell'atto o degli atti di indagine preliminare indicati nel comma 2 lettera a. L'ordinanza è immediatamente comunicata al pubblico ministero e notificata per estratto alle persone indicate nell'articolo 393 comma 1 lettera b. La richiesta di differimento e l'ordinanza sono depositate alla udienza.

Art. 398. Provvedimenti sulla richiesta di incidente probatório.

1. Entro due giorni dal deposito della prova della notifica e comunque dopo la scadenza del termine previsto dall'articolo 396 comma 1, il giudice pronuncia ordinanza con la quale accoglie, dichiara inammissibile o rigetta la richiesta di incidente probatorio. L'ordinanza di inammissibilità o di rigetto è immediatamente comunicata al pubblico ministero e notificata alle persone interessate.

2. Con l'ordinanza che accoglie la richiesta il giudice stabilisce:

a) l'oggetto della prova nei limiti della richiesta e delle deduzioni;

b) le persone interessate all'assunzione della prova individuate sulla base della richiesta e delle deduzioni;

c) la data dell'udienza. Tra il provvedimento e la data dell'udienza non può intercorrere un termine superiore a dieci giorni.

3. Il giudice fa notificare alla persona sottoposta alle indagini, alla persona offesa e ai difensori avviso del giorno, dell'ora e del luogo in cui si deve procedere all'incidente probatorio almeno due giorni prima della data fissata con l'avvertimento che nei due giorni precedenti l'udienza possono prendere cognizione ed estrarre copia delle dichiarazioni già rese dalla persona da esaminare. Nello stesso termine l'avviso è comunicato al pubblico ministero.

3-bis. La persona sottoposta alle indagini ed i difensori delle parti hanno diritto di ottenere copia degli atti depositati ai sensi dell'articolo 393, comma 2-bis.

4. Se si deve procedere a più incidenti probatori, essi sono assegnati alla medesima udienza, sempre che non ne derivi ritardo.

5. Quando ricorrono ragioni di urgenza e l'incidente probatorio non può essere svolto nella circoscrizione del giudice competente, quest'ultimo può delegare il giudice per le indagini preliminari del luogo dove la prova 
deve essere assunta.

5-bis. Nel caso di indagini che riguardano ipotesi di reato previste dagli articoli 600, 600-bis, 600-ter, anche se relativo al material pornografico di cui all'articolo 600-quater.1, 600-quinquies, 601, 602, 609-bis, 609-ter, 609-quater e 609-octies del codice penale, il giudice, ove fra le persone interessate all'assunzione della prova vi siano minori di anni sedici, con l'ordinanza di cui al comma 2, stabilisce il luogo, il tempo e le modalità particolari attraverso cui procedere allincidente probatorio, quando le esigenze del minore lo rendono necessario od opportuno. A tal fine l'udienza può svolgersi anche in luogo diverso dal tribunale, avvalendosi il giudice, ove esistano, di strutture specializzate di assistenza o, in mancanza, presso l'abitazione dello stesso minore. Le dichiarazioni testimoniali debbono essere documentate integralmente con mezzi di produzione fonografica o audiovisiva. Quando si verifica una indisponibilità di strumenti di riproduzione o di personale tecnico, si provvede con le forme della perizia ovvero della consulenza tecnica. Dell'interrogatorio è anche redatto verbale in forma riassuntiva. La trascrizione della riproduzione è disposta solo se richiesta dalle parti.

Art. 399. Accompagnamento coattivo della persona sottoposta alle indagini.

1. Se la persona sottoposta alle indagini, la cui presenza è necessaria per compiere un atto da assumere con l'incidente probatorio, non compare senza addurre un legittimo impedimento, il giudice ne ordina l'accompagnamento coattivo.

Art. 400. Provvedimenti per i casi di urgenza.

1. Quando per assicurare l'assunzione della prova è indispensabile procedere con urgenza all'incidente probatorio, il giudice dispone con decreto motivato che i termini previsti dagli articoli precedenti siano abbreviati nella misura necessaria.

Art. 401. Udienza.

1. L'udienza si svolge in camera di consiglio con la partecipazione necessaria del pubblico ministero e del difensore della persona sottoposta alle indagini. Ha altresì diritto di parteciparvi il difensore della persona offesa.

2. In caso di mancata comparizione del difensore della persona sottoposta alle indagini, il giudice designa altro difensore a norma dell'articolo 97 comma 4.

3. La persona sottoposta alle indagini e la persona offesa hanno diritto di assistere all'incidente probatorio quando si deve esaminare un testimone o un'altra persona. Negli altri casi possono assistere previa autorizzazione del giudice.

4. Non è consentita la trattazione e la pronuncia di nuovi provvedimenti su questioni relative all'ammissibilità e alla fondatezza della richiesta.

5. Le prove sono assunte con le forme stabilite per il dibattimento. Il difensore della persona offesa può chiedere al giudice di rivolgere domande alle persone sottoposte ad esame.

6. Salvo quanto previsto dall'articolo 402, è vietato estendere l'assunzione della prova a fatti riguardanti persone diverse da quelle i cui difensori partecipano all'incidente probatorio. E' in ogni caso vietato verbalizzare dichiarazioni riguardanti tali soggetti.

7. Se l'assunzione della prova non si conclude nella medesima udienza, il giudice ne dispone il rinvio al giorno successivo non festivo, salvo che lo svolgimento delle attività di prova richieda un termine maggiore.

8. Il verbale, le cose e i documenti acquisiti nell'incidente probatorio sono trasmessi al pubblico ministero. I difensori hanno diritto di prenderne visione ed estrarne copia.

Art. 402. Estensione dell'incidente probatório.

1. Se il pubblico ministero o il difensore della persona sottoposta alle indagini chiede che la prova si estenda ai fatti o alle dichiarazioni previsti dall'articolo 401 comma 6, il giudice, se ne ricorrono i requisiti dispone le necessarie notifiche a norma dell'articolo 398 comma 3 rinviando l'udienza per il tempo strettamente necessario e comunque non oltre tre giorni. La richiesta non è accolta se il rinvio pregiudica l'assunzione della prova.

Art. 403. Utilizzabilità nel dibattimento delle prove assunte con incidente probatório.

1. Nel dibattimento le prove assunte con l'incidente probatorio sono utilizzabili soltanto nei confronti degli imputati i cui difensori hanno partecipato alla loro assunzione. 
1-bis. Le prove di cui al comma 1 non sono utilizzabili nei confronti dell'imputato raggiunto solo successivamente all'incidente probatorio da indizi di colpevolezza se il difensore non ha partecipato alla loro assunzione, salvo che i suddetti indizi siano emersi dopo che la ripetizione dell'atto sia divenuta impossibile.

Art. 404. Efficacia dell'incidente probatorio nei confronti della parte civile.

1. La sentenza pronunciata sulla base di una prova assunta con incidente probatorio a cui il danneggiato dal reato non è stato posto in grado di partecipare non produce gli effetti previsti dall'articolo 652, salvo che il danneggiato stesso ne abbia fatta accettazione anche tacita.

Titolo VIII: Chiusura delle indagini preliminari

Art. 405. Inizio dell'azione penale. Forme e termini.

1. Il pubblico ministero, quando non deve richiedere l'archiviazione, esercita l'azione penale, formulando l'imputazione, nei casi previsti nei titoli II, III, IV e V del libro VI ovvero con richiesta di rinvio a giudizio.

1-bis. Il publico ministero, al termine delle indagini, formula richiesta di archiviazione quando la Corte di cassazione si é pronunciata in ordine alla insussistenza dei gravi indizi di colpevolezza, ai sensi dell'articolo 273, e non sono stati acquisiti, successivamente, ulteriori elementi a carico della persona sottoposta alle indagini.

2. Salvo quanto previsto dall'articolo 415-bis, il pubblico ministero richiede il rinvio a giudizio entro sei mesi dalla data in cui il nome della persona alla quale è attribuito il reato è iscritto nel registro delle notizie di reato. Il termine è di un anno se si procede per taluno dei delitti indicati nell'articolo 407, comma 2, lettera a.

3. Se è necessaria la querela, l'istanza o la richiesta di procedimento, il termine decorre dal momento in cui queste pervengono al pubblico ministero.

4. Se è necessaria l'autorizzazione a procedere, il decorso del termine è sospeso dal momento della richiesta a quello in cui l'autorizzazione perviene al pubblico ministero.

Art. 406. Proroga del termine.

1. Il pubblico ministero, prima della scadenza, può richiedere al giudice, per giusta causa, la proroga del termine previsto dall'articolo 405. La richiesta contiene l'indicazione della notizia di reato e l'esposizione dei motivi che la giustificano.

2. Ulteriori proroghe possono essere richieste dal pubblico ministero nei casi di particolare complessità delle indagini ovvero di oggettiva impossibilità di concluderle entro il termine prorogato.

2-bis. Ciascuna proroga può essere autorizzata dal giudice per un tempo non superiore a sei mesi.

2-ter. Qualora si proceda per i reati di cui agli articoli 589, secondo comma, e 590, terzo comma, del codice penale, la proroga di cui al comma 1 può essere concessa per no più di una volta.

3. La richiesta di proroga è notificata, a cura del giudice, con l'avviso della facoltà di presentare memorie entro cinque giorni dalla notificazione, alla persona sottoposta alle indagini nonché alla persona offesa dal reato che, nella notizia di reato o successivamente alla sua presentazione, abbia dichiarato di volere esserne informata. Il giudice provvede entro dieci giorni dalla scadenza del termine per la presentazione delle memorie.

4. Il giudice autorizza la proroga del termine con ordinanza emessa in camera di consiglio senza intervento del pubblico ministero e dei difensori.

5. Qualora ritenga che allo stato degli atti non si debba concedere la proroga, il giudice, entro il termine previsto dal comma 3 secondo periodo, fissa la data dell'udienza in camera di consiglio e ne fa notificare avviso al pubblico ministero, alla persona sottoposta alle indagini nonché, nella ipotesi prevista dal comma 3 , alla persona offesa dal reato. Il procedimento si svolge nelle forme previste dall'articolo 127.

5-bis. Le disposizioni dei commi 3, 4 e 5 non si applicano se si procede per taluno dei delitti indicati nell'articolo 51 comma 3-bis e nell'articolo 407, comma 2, lettera a, numeri 4 e 7-bis. In tali casi, il giudice 
provvede con ordinanza entro dieci giorni dalla presentazione della richiesta, dandone comunicazione al pubblico ministero.

6. Se non ritiene di respingere la richiesta di proroga, il giudice autorizza con ordinanza il pubblico ministero a proseguire le indagini.

7. Con l'ordinanza che respinge la richiesta di proroga, il giudice, se il termine per le indagini preliminari è già scaduto, fissa un termine non superiore a dieci giorni per la formulazione delle richieste del pubblico ministero a norma dell'articolo 405.

8. Gli atti di indagine compiuti dopo la presentazione della richiesta di proroga e prima della comunicazione del provvedimento del giudice sono comunque utilizzabili, sempre che, nel caso di provvedimento negativo, non siano successivi alla data di scadenza del termine originariamente previsto per le indagini.

Art. 407. Termini di durata massima delle indagini preliminari.

1. Salvo quanto previsto all'articolo 393 comma 4, la durata delle indagini preliminari non può comunque superare diciotto mesi.

2. La durata massima è tuttavia di due anni se le indagini preliminari riguardano:

a) i delitti appresso indicati:

1) delitti di cui agli articoli 285, 286, 416-bis e 422, del c.p., 291-ter, limitatamente alle ipotesi aggravate previste dalle lettere a, d ed e del comma 2, e 291-quater, comma 4, del testo unico approvato con decreto del Presidente della Repubblica 23 gennaio 1973, n. 43;

2) delitti consumati o tentati di cui agli articoli 575, 628, terzo comma, 629, secondo comma, e 630 dello stesso c.p.;

3) delitti commessi avvalendosi delle condizioni previste dall'articolo 416-bis del c.p. ovvero al fine di agevolare l'attività delle associazioni previste dallo stesso articolo;

4) delitti commessi per finalità di terrorismo o di eversione dell'ordinamento costituzionale per i quali la legge stabilisce la pena della reclusione non inferiore nel mínimo a cinque anni o nel massimo a dieci anni, nonché delitti di cui agli articoli 270, terzo comma e 306, secondo comma, del c.p.;

5) delitti di illegale fabbricazione, introduzione nello Stato, messa in vendita, cessione, detenzione e porto in luogo pubblico o aperto al pubblico di armi da guerra o tipo guerra o parti di esse, di esplosivi, di armi clandestine nonché di più armi comuni da sparo escluse quelle previste dall'articolo 2, comma terzo, della legge 18 aprile 1975, n. 110;

6) delitti di cui agli articoli 73, limitatamente alle ipotesi aggravate ai sensi dell'articolo 80, comma 2, e 74 del testo unico delle leggi in materia di disciplina degli stupefacenti e sostanze psicotrope, prevenzione, cura e riabilitazione dei relativi stati di tossicodipendenza, approvato con decreto del Presidente della Repubblica 9 ottobre 1990, n. 309, e successive modificazioni;

7) delitto di cui all'articolo 416 del c.p. nei casi in cui è obbligatorio l'arresto in flagranza;

7-bis) dei delitti previsto dagli articoli 600, 600-bis, comma 1, 600-ter, comma 1, 601, 602, 609-bis, nelle ipotesi aggravate previste dall'articolo 609-ter, 609-quater, 609-octies del c.p.;

b) notizie di reato che rendono particolarmente complesse le investigazioni per la molteplicità di fatti tra loro collegati ovvero per l'elevato numero di persone sottoposte alle indagini o di persone offese;

c) indagini che richiedono il compimento di atti all'estero;

d) procedimenti in cui è indispensabile mantenere il collegamento tra più uffici del pubblico ministero a norma dell'articolo 371.

3. Salvo quanto previsto dall'articolo 415-bis, qualora il pubblico ministero non abbia esercitato l'azione penale o richiesto l'archiviazione nel termine stabilito dalla legge o prorogato dal giudice, gli atti di indagine compiuti dopo la scadenza del termine non possono essere utilizzati.

Art. 408. Richiesta di archiviazione per infondatezza della notizia di reato.

1. Entro i termini previsti dagli articoli precedenti, il pubblico ministero, se la notizia di reato è infondata, presenta al giudice richiesta di archiviazione. Con la richiesta è trasmesso il fascicolo contenente la notizia di reato, la documentazione relativa alle indagini espletate e i verbali degli atti compiuti davanti al giudice per le 
indagini preliminari.

2. L'avviso della richiesta è notificato, a cura del pubblico ministero alla persona offesa che, nella notizia di reato o successivamente alla sua presentazione, abbia dichiarato di volere essere informata circa l'eventuale archiviazione.

3. Nell'avviso è precisato che, nel termine di dieci giorni, la persona offesa può prendere visione degli atti e presentare opposizione con richiesta motivata di prosecuzione delle indagini preliminari.

Art. 409. Provvedimenti del giudice sulla richiesta di archiviazione.

1. Fuori dei casi in cui sia stata presentata l'opposizione prevista dall'articolo 410, il giudice, se accoglie la richiesta di archiviazione, pronuncia decreto motivato e restituisce gli atti al pubblico ministero. Il provvedimento che dispone l'archiviazione è notificato alla persona sottoposta alle indagini se nel corso del procedimento è stata applicata nei suoi confronti la misura della custodia cautelare.

2. Se non accoglie la richiesta, il giudice fissa la data dell'udienza in camera di consiglio e ne fa dare avviso al pubblico ministero, alla persona sottoposta alle indagini e alla persona offesa dal reato. Il procedimento si svolge nelle forme previste dall'articolo 127. Fino al giorno dell'udienza gli atti restano depositati in cancelleria con facoltà del difensore di estrarne copia.

3. Della fissazione dell'udienza il giudice dà inoltre comunicazione al procuratore generale presso la corte di appello.

4. A seguito dell'udienza, il giudice, se ritiene necessarie ulteriori indagini, le indica con ordinanza al pubblico ministero, fissando il termine indispensabile per il compimento di esse.

5. Fuori del caso previsto dal comma 4, il giudice, quando non accoglie la richiesta di archiviazione, dispone con ordinanza che, entro dieci giorni, il pubblico ministero formuli l'imputazione. Entro due giorni dalla formulazione dell'imputazione, il giudice fissa con decreto l'udienza preliminare. Si osservano, in quanto applicabili, le disposizioni degli articoli 418 e 419.

6. L'ordinanza di archiviazione è ricorribile per cassazione solo nei casi di nullità previsti dall'articolo 127 comma 5.

Art. 410. Opposizione alla richiesta di archiviazione.

1. Con l'opposizione alla richiesta di archiviazione la persona offesa dal reato chiede la prosecuzione delle indagini preliminari indicando, a pena di inammissibilità, l'oggetto della investigazione suppletiva e i relativi elementi di prova.

2. Se l'opposizione è inammissibile e la notizia di reato è infondata, il giudice dispone l'archiviazione con decreto motivato e restituisce gli atti al pubblico ministero.

3. Fuori dei casi previsti dal comma 2, il giudice provvede a norma dell'articolo 409 commi 2, 3, 4 e 5, ma, in caso di più persone offese, l'avviso per l'udienza è notificato al solo opponente.

Art. 411. Altri casi di archiviazione.

1. Le disposizioni degli articoli 408,409 e 410 si applicano anche quando risulta che manca una condizione di procedibilità, che il reato è estinto o che il fatto non è previsto dalla legge come reato.

Art. 412. Avocazione delle indagini preliminari per mancato esercizio dell'azione penale.

1. Il procuratore generale presso la corte di appello dispone con decreto motivato l'avocazione delle indagini preliminari se il pubblico ministero non esercita l'azione penale o non richiede l'archiviazione nel termine stabilito dalla legge o prorogato dal giudice. Il procuratore generale svolge le indagini preliminari indispensabili e formula le sue richieste entro trenta giorni dal decreto di avocazione.

2. Il procuratore generale può altresì disporre l'avocazione a seguito della comunicazione prevista dall'articolo 409 comma 3.

Art. 413. Richiesta della persona sottoposta alle indagini o della persona offesa dal reato.

1. La persona sottoposta alle indagini o la persona offesa dal reato può chiedere al procuratore generale di disporre l'avocazione a norma dell'articolo 412 comma 1.

2. Disposta l'avocazione, il procuratore generale svolge le indagini preliminari indispensabili e formula le sue richieste entro trenta giorni dalla richiesta proposta a norma del comma 1. 
Art. 414. Riapertura delle indagini

1. Dopo il provvedimento di archiviazione emesso a norma degli articoli precedenti, il giudice autorizza con decreto motivato la riapertura delle indagini su richiesta del pubblico ministero motivata dalla esigenza di nuove investigazioni.

2. Quando è autorizzata la riapertura delle indagini, il pubblico ministero procede a nuova iscrizione a norma dell'articolo 335.

Art. 415. Reato commesso da persone ignote.

1. Quando è ignoto l'autore del reato, il pubblico ministero, entro sei mesi dalla data della registrazione della notizia di reato, presenta al giudice richiesta di archiviazione ovvero di autorizzazione a proseguire le indagini.

2. Quando accoglie la richiesta di archiviazione ovvero di autorizzazione a proseguire le indagini, il giudice pronuncia decreto motivato e restituisce gli atti al pubblico ministero. Se ritiene che il reato sia da attribuire a persona già individuata, ordina che il nome di questa sia iscritto nel registro delle notizie di reato.

3. Si ooservano, in quanto applicabili, le altre disposizioni di cui al presente titolo.

4. Nell'ipotesi di cui all'articolo 107-bis delle norme di attuazione, di coordinamento e transitorie, la richiesta di archiviazione ed il decreto del giudice che accoglie la richiesta sono pronunciati cumulativamente con riferimento agli elenchi trasmessi dagli organi di polizia con l'eventuale indicazione delle denunce che il pubblico ministero o il giudice intendono escludere, rispettivamente, dalla richiesta o dal decreto.

Art. 415-bis. Avviso all'indagato della conclusione delle indagini preliminari.

1. Prima della scadenza del termine previsto dal comma 2 dell'articolo 405, anche se prorogato, il pubblico ministero, se non deve formulare richiesta di archiviazione ai sensi degli articoli 408 e 411, fa notificare alla persona sottoposta alle indagini e al difensore avviso della conclusione delle indagini preliminari.

2. L'avviso contiene la sommaria enunciazione del fatto per il quale si procede, delle norme di legge che si assumono violate, della data e del luogo del fatto, con l'avvertimento che la documentazione relativa alle indagini espletate è depositata presso la segreteria del pubblico ministero e che l'indagato e il suo difensore hanno facoltà di prenderne visione ed estrarne copia.

3. L'avviso contiene altresì l'avvertimento che l'indagato ha facoltà, entro il termine di venti giorni, di presentare memorie, produrre documenti, depositare documentazione relativa ad investigazioni del difensore, chiedere al pubblico ministero il compimento di atti di indagine, nonché di presentarsi per rilasciare dichiarazioni ovvero chiedere di essere sottoposto ad interrogatorio. Se l'indagato chiede di essere sottoposto ad interrogatorio il pubblico ministero deve procedervi.

4. Quando il pubblico ministero, a seguito delle richieste dell'indagato, dispone nuove indagini, queste devono essere compiute entro trenta giorni dalla presentazione della richiesta. Il termine può essere prorogato dal giudice per le indagini preliminari, su richiesta del pubblico ministero, per una sola volta e per non più di sessanta giorni.

5. Le dichiarazioni rilasciate dall'indagato, l'interrogatorio del medesimo ed i nuovi atti di indagine del pubblico ministero, previsti dai commi 3 e 4, sono utilizzabili se compiuti entro il termine stabilito dal comma 4, ancorché sia decorso il termine stabilito dalla legge o prorogato dal giudice per l'esercizio dell'azione penale o per la richiesta di archiviazione.

Titolo IX: Udienza preliminare

Art. 416. Presentazione della richiesta del pubblico ministero.

1. La richiesta di rinvio a giudizio è depositata dal pubblico ministero nella cancelleria del giudice. La richiesta di rinvio a giudizio è nulla se non è preceduta dall'avviso previsto dall'articolo 415-bis, nonché dall'invito a presentarsi per rendere l'interrogatorio ai sensi dell'articolo 375, comma 3, qualora la persona sottoposta alle indagini abbia chiesto di essere sottoposta ad interrogatorio entro il termine di cui all'articolo 415-bis, comma 3. 
2. Con la richiesta è trasmesso il fascicolo contenente la notizia di reato , la documentazione relativa alle indagini espletate e i verbali degli atti compiuti davanti al giudice per le indagini preliminari. Il corpo del reato e le cose pertinenti al reato sono allegati al fascicolo, qualora non debbano essere custoditi altrove.

2-bis. Qualora si proceda per il reato di cui all'articolo 589, secondo comma, del codice penale, la richiesta di rinvio a giudizio del pubblico ministero deve essere depositata entro trenta giorni dalla chiusura delle indagini preliminari.

Art. 417. Requisiti formali della richiesta di rinvio a giudizio.

1. La richiesta di rinvio a giudizio contiene:

a) le generalità dell'imputato o le altre indicazioni personali che valgono a identificarlo nonchè le generalità della persona offesa dal reato qualora ne sia possibile l'identificazione;

b) I'enunciazione, in forma chiara e precisa, del fatto, delle circostanze aggravanti e di quelle che possono comportare l'applicazione di misure di sicurezza, con l'indicazione dei relativi articoli di legge;

c) I'indicazione delle fonti di prova acquisite;

d) la domanda al giudice di emissione del decreto che dispone il giudizio;

e) la data e la sottoscrizione.

Art. 418. Fissazione dell'udienza.

1. Entro due giorni dal deposito della richiesta, il giudice fissa con decreto il giorno, I'ora e il luogo dell'udienza in camera di consiglio provvedendo a norma dell'art. 97 quando l'imputato è privo di difensore di fiducia.

2. Tra la data di deposito della richiesta e la data dell'udienza non può intercorrere un termine superiore a trenta giorni.

Art. 419. Atti introdutttvi.

1. Il giudice fa notificare all'imputato e alla persona offesa, della quale risulti agli atti l'identità e il domicilio, l'avviso del giorno, dell'ora e del luogo dell'udienza, con la richiesta di rinvio a giudizio formulata dal pubblico ministero e con l'avvertimento all'imputato che non comparendo sarà giudicato in contumacia.

2. L'avviso è altresì comunicato al pubblico ministero e notificato al difensore dell'imputato con l'avvertimento della facoltà di prendere visione degli atti e delle cose trasmessi a norma dell'articolo 416 comma 2 e di presentare memorie e produrre documenti.

3. L'avviso contiene inoltre l'invito a trasmettere la documentazione relativa alle indagini eventualmente espletate dopo la richiesta di rinvio a giudizio.

4. Gli avvisi sono notificati e comunicati almeno dieci giorni prima della data dell'udienza. Entro lo stesso termine è notificata la citazione del responsabile civile e della persona civilmente obbligata per la pena pecuniaria.

5. L'imputato può rinunciare all'udienza preliminare e richiedere il giudizio immediato con dichiarazione presentata in cancelleria, personalmente o a mezzo di procuratore speciale, almeno tre giorni prima della data dell'udienza. L'atto di rinuncia è notificato al pubblico ministero e alla persona offesa dal reato a cura dell'imputato.

6. Nel caso previsto dal comma 5, il giudice emette decreto di giudizio immediato.

7. Le disposizioni dei commi 1 e 4 sono previste a pena di nullità.

Art. 420. Costituzione delle parti.

1. L'udienza si svolge in camera di consiglio con la partecipazione necessaria del pubblico ministero e del difensore dell'imputato.

2. Il giudice procede agli accertamenti relativi alla costituzione delle parti ordinando la rinnovazione degli avvisi, delle citazioni, delle comunicazioni e delle notificazioni di cui dichiara la nullità.

3. Se il difensore dell'imputato non è presente, il giudice provvede a norma delI'articolo 97 comma 4.

4. Il verbale dell'udienza preliminare è redatto di regola in forma riassuntiva a norma dell'articolo 140, 
comma 2; il giudice, su richiesta di parte, dispone la riproduzione fonografica o audiovisiva ovvero la redazione del verbale con la stenotipia.

Art.420-bis. Rinnovazione dell'avviso.

1. Il giudice dispone, anche di ufficio, che sia rinnovato l'avviso dell'udienza preliminare a norma dell'articolo 419, comma 1, quando è provato o appare probabile che l'imputato non ne abbia avuto effettiva conoscenza, sempre che il fatto non sia dovuto a sua colpa e fuori dei casi di notificazione mediante consegna al difensore a norma degli articoli 159, 161, comma 4, e 169.

2. La probabilità che l'imputato non abbia avuto conoscenza dell'avviso è liberamente valutata dal giudice. Tale valutazione non può formare oggetto di discussione successiva né motivo di impugnazione.

Art. 420-ter. Impedimento a comparire dell'imputato o del difensore.

1. Quando l'imputato, anche se detenuto, non si presenta all'udienza e risulta che l'assenza è dovuta ad assoluta impossibilità di comparire per caso fortuito, forza maggiore o altro legittimo impedimento, il giudice, con ordinanza, anche d'ufficio, rinvia ad una nuova udienza e dispone che sia rinnovato l'avviso all'imputato, a norma dell'articolo 419, comma 1.

2. Con le medesime modalità di cui al comma 1 il giudice provvede quando appare probabile che l'assenza dell'imputato sia dovuta ad assoluta impossibilità di comparire per caso fortuito o forza maggiore. Tale probabilità è liberamente valutata dal giudice e non può formare oggetto di discussione successiva né motivo di impugnazione.

3. Quando l'imputato, anche se detenuto, non si presenta alle successive udienze e ricorrono le condizioni previste dal comma 1, il giudice rinvia anche d'ufficio l'udienza, fissa con ordinanza la data della nuova udienza e ne dispone la notificazione all'imputato.

4. In ogni caso la lettura dell'ordinanza che fissa la nuova udienza sostituisce la citazione e gli avvisi per tutti coloro che sono o devono considerarsi presenti.

5. Il giudice provvede a norma del comma 1 nel caso di assenza del difensore, quando risulta che l'assenza stessa è dovuta ad assoluta impossibilità di comparire per legittimo impedimento, purché prontamente comunicato. Tale disposizione non si applica se l'imputato è assistito da due difensori e l'impedimento riguarda uno dei medesimi ovvero quando il difensore impedito ha designato un sostituto o quando l'imputato chiede che si proceda in assenza del difensore impedito.

Art. 420-quater. Contumacia dell'imputato.

1. Se l'imputato, libero o detenuto, non compare all'udienza e non ricorrono le condizioni indicate negli articoli 420, comma 2, 420-bis e 420-ter, commi 1 e 2, il giudice, sentite le parti, ne dichiara la contumacia.

2. L'imputato, quando si procede in sua contumacia, è rappresentato dal suo difensore.

3. Se l'imputato compare prima che il giudice adotti i provvedimenti di cui al comma 1 dell'articolo 424, il giudice revoca l'ordinanza che ha dichiarato la contumacia. In tal caso l'imputato può rendere dichiarazioni spontanee e chiedere di essere sottoposto ad interrogatorio.

4. L'ordinanza dichiarativa di contumacia è nulla se al momento della pronuncia vi è la prova che l'assenza dell'imputato è dovuta a mancata conoscenza dell'avviso a norma dell'articolo 420-bis ovvero ad assoluta impossibilità di comparire per caso fortuito, forza maggiore od altro legittimo impedimento.

5. Se la prova dell'assenza indicata nel comma 4 perviene dopo la pronuncia dell'ordinanza prevista dal comma 1, ma prima dei provvedimenti cui al comma 1 dell'articolo 424, il giudice revoca l'ordinanza medesima e, se l'imputato non è comparso, rinvia anche d'ufficio l'udienza. Restano comunque validi gli atti compiuti in precedenza, ma se l'imputato ne fa richiesta e dimostra che la prova è pervenuta con ritardo senza sua colpa, il giudice dispone l'assunzione o la rinnovazione degli atti che ritiene rilevanti ai fini dei provvedimenti di cui al comma 1 dell'articolo 424.

6. Quando si procede a carico di più imputati, si applicano le disposizioni dell'articolo 18, comma 1, lettere c e d.

7. L'ordinanza dichiarativa della contumacia è allegata al decreto che dispone il giudizio. Nel decreto è in ogni caso indicato se l'imputato è contumace o assente.

Art. 420-quinquies. Assenza e allontanamento volontario dell'imputato. 
1. Le disposizioni degli articoli 420-bis e 420-ter non si applicano quando l'imputato, anche se impedito, chiede o consente che l'udienza preliminare avvenga in sua assenza o, se detenuto, rifiuta di assistervi. L'imputato in tali casi è rappresentato dal difensore.

2. L'imputato che, dopo essere comparso, si allontana dall'aula di udienza è considerato presente ed è rappresentato dal difensore.

Art. 421. Discussione.

1. Conclusi gli accertamenti relativi alla costituzione delle parti il giudice dichiara aperta la discussione.

2. Il pubblico ministero espone sinteticamente i risultati delle indagini preliminari e gli elementi di prova che giustificano la richiesta di rinvio a giudizio. L'imputato può rendere dichiarazioni spontanee e chiedere di essere sottoposto all'interrogatorio, per il quale si applicano le disposizioni degli articoli 64 e 65. Su richiesta di parte, il giudice dispone che l'interrogatorio sia reso nelle forme previste dagli articoli 498 e 499 . Prendono poi la parola, nell'ordine, i difensori della parte civile, del responsabile civile della persona civilmente obbligata per la pena pecuniaria e dell'imputato che espongono le loro difese. Il pubblico ministero e i difensori possono replicare una sola volta.

3. Il pubblico ministero e i difensori formulano e illustrano le rispettive conclusioni utilizzando gli atti contenuti nel fascicolo trasmesso a norma dell'articolo 416 comma 2 nonché gli atti e i documenti ammessi dal giudice prima dell'inizio della discussione.

4. Se il giudice ritiene di poter decidere allo stato degli atti, dichiara chiusa la discussione.

Art. 421-bis. Ordinanza per l'integrazione delle indagini.

1. Quando non provvede a norma del comma 4 dell'articolo 421, il giudice, se le indagini preliminari sono incomplete, indica le ulteriori indagini, fissando il termine per il loro compimento e la data della nuova udienza preliminare. Del provvedimento è data comunicazione al procuratore generale presso la corte d'appello.

2. Il procuratore generale presso la corte d'appello può disporre con decreto motivato l'avocazione delle indagini a seguito della comunicazione prevista dal comma 1 . Si applica, in quanto compatibile, la disposizione dell'articolo 412, comma 1.

Art. 422. Attività di integrazione probatoria del giudice.

1. Quando non provvede a norma del comma 4 dell'articolo 421, ovvero a norma dell'articolo 421-bis, il giudice può disporre, anche d'ufficio, l'assunzione delle prove delle quali appare evidente la decisività ai fini della sentenza di non luogo a procedere.

2. Il giudice, se non è possibile procedere immediatamente all'assunzione delle prove, fissa la data della nuova udienza e dispone la citazione dei testimoni, dei periti, dei consulenti tecnici e delle persone indicate nell'articolo 210 di cui siano stati ammessi l'audizione o l'interrogatorio.

3. L'audizione e l'interrogatorio delle persone indicate nel comma 2 sono condotti dal giudice. Il pubblico ministero e i difensori possono porre domande, a mezzo del giudice, nell'ordine previsto dall'articolo 421, comma 2. Successivamente, il pubblico ministero e i difensori formulano e illustrano le rispettive conclusioni.

4. In ogni caso l'imputato può chiedere di essere sottoposto all'interrogatorio, per il quale si applicano le disposizioni degli articoli 64 e 65. Su richiesta di parte, il giudice dispone che l'interrogatorio sia reso nelle forme previste dagli articoli 498 e 499.

Art. 423. Modificazione dell'imputazione.

1. Se nel corso dell'udienza il fatto risulta diverso da come è descritto nell'imputazione ovvero emerge un reato connesso a norma dell'articolo 12 comma 1 lettera b), o una circostanza aggravante, il pubblico ministero modifica l'imputazione e la contesta all'imputato presente. Se l'imputato non è presente, la modificazione della imputazione è comunicata al difensore, che rappresenta l'imputato ai fini della contestazione.

2. Se risulta a carico dell'imputato un fatto nuovo non enunciato nella richiesta di rinvio a giudizio, per il quale si debba procedere di ufficio, il giudice ne autorizza la contestazione se il pubblico ministero ne fa richiesta e vi è il consenso dell'imputato. 
Art. 424. Provvedimenti del giudice.

1. Subito dopo che è stata dichiarata chiusa la discussione, il giudice procede alla deliberazione pronunciando sentenza di non luogo a procedere o decreto che dispone il giudizio.

2. Il giudice dà immediata lettura del provvedimento. La lettura equivale a notificazione per le parti presenti.

3. Il provvedimento è immediatamente depositato in cancelleria. Le parti hanno diritto di ottenerne copia.

4. Qualora non sia possibile procedere alla redazione immediata dei motivi della sentenza di non luogo a procedere, il giudice provvede non oltre il trentesimo giorno da quello della pronuncia.

Art. 425. Sentenza di non luogo a procedere.

1. Se sussiste una causa che estingue il reato o per la quale l'azione penale non doveva essere iniziata o non deve essere proseguita, se il fatto non è previsto dalla legge come reato ovvero quando risulta che il fatto non sussiste o che l'imputato non lo ha commesso o che il fatto non costituisce reato o che si tratta di persona non punibile per qualsiasi causa, il giudice pronuncia sentenza di non luogo a procedere, indicandone la causa nel dispositivo.

2. Ai fini della pronuncia della sentenza di cui al comma 1, il giudice tiene conto delle circostanze attenuanti. Si applicano le disposizioni dell'articolo 69 del codice penale.

3. Il giudice pronuncia sentenza di non luogo a procedere anche quando gli elementi acquisiti risultano insufficienti, contraddittori o comunque non idonei a sostenere l'accusa in giudizio.

4. Il giudice non può pronunciare sentenza di non luogo a procedere se ritiene che dal proscioglimento dovrebbe conseguire l'applicazione di una misura di sicurezza diversa dalla confisca.

5. Si applicano le disposizioni dell'articolo 537.

Art. 426. Requisiti della sentenza.

1. La sentenza contiene:

a) l'intestazione «in nome del popolo italiano» e l'indicazione dell'autorità che l'ha pronunciata;

b) le generalità dell'imputato o le altre indicazioni personali che valgono a identificarlo nonché le generalità delle altre parti private;

c) l'imputazione;

d) l'esposizione sommaria dei motivi di fatto e di diritto su cui la decisione è fondata;

e) il dispositivo, con l'indicazione degli articoli di legge applicati;

f) la data e la sottoscrizione del giudice.

2. In caso di impedimento del giudice, la sentenza è sottoscritta dal presidente del tribunale previa menzione della causa della sostituzione.

3. Oltre che nel caso previsto dall'articolo 125 comma 3, la sentenza è nulla se manca o è incompleto nei suoi elementi essenziali il dispositivo ovvero se manca la sottoscrizione del giudice.

Art. 427. Condanna del querelante alle spese e ai danni.

1. Quando si tratta di reato per il quale si procede a querela della persona offesa, con la sentenza di non luogo a procedere perché il fatto non sussiste o l'imputato non lo ha commesso il giudice condanna il querelante al pagamento delle spese del procedimento anticipate dallo Stato. (1)

2. Nei casi previsti dal comma 1 , il giudice, quando ne è fatta domanda, condanna inoltre il querelante alla rifusione delle spese sostenute dall'imputato e, se il querelante si è costituito parte civile, anche di quelle sostenute dal responsabile civile citato o intervenuto. Quando ricorrono giusti motivi, le spese possono essere compensate in tutto o in parte.

3. Se vi è colpa grave, il giudice può condannare il querelante a risarcire i danni all'imputato e al responsabile civile che ne abbiano fatto domanda.

4. Contro il capo della sentenza di non luogo a procedere che decide sulle spese e sui danni possono proporre impugnazione, a norma dell'articolo 428, il querelante, l'imputato e il responsabile civile. 
5. Se il reato è estinto per remissione della querela, si applica la disposizione dell'articolo 340 comma 4.

Art. 428. Impugnazione della sentenza di non luogo a procedere.

1. Contro la sentenza di non luogo a procedere possono proporre ricorso per cassazione:

a) il procuratore della Repubblica e il procuratore generale;

b) l'imputato, salvo che con la sentenza sia stato dichiarato che il fatto non sussiste o che l'imputato non lo ha commesso.

2. La persona offesa può proporre ricorso per cassazione nei soli casi di nullità previsti dall'articolo 419 , comma 7. La persona offesa costituita parte civile può proporre ricorso per cassazione ai sensi dell'articolo 606.

3. Sull'impugnazione decide la Corte di cassazione in camera di consiglio con le forme previste dall'articolo 127.

Art. 429. Decreto che dispone il giudizio.

1. Il decreto che dispone il giudizio contiene:

a) le generalità dell'imputato e le altre indicazioni personali che valgono a identificarlo nonché le generalità delle altre parti private, con l'indicazione dei difensori;

b) l'indicazione della persona offesa dal reato qualora risulti identificata;

c) l'enunciazione, in forma chiara e precisa, del fatto, delle circostanze aggravanti e di quelle che possono comportare l'applicazione di misure di sicurezza, con l'indicazione dei relativi articoli di legge;

d) l'indicazione sommaria delle fonti di prova e dei fatti cui esse si riferiscono;

e) il dispositivo, con l'indicazione del giudice competente per il giudizio;

f) l'indicazione del luogo, del giorno e dell'ora della comparizione, con l'avvertimento all'imputato che non comparendo sarà giudicato in contumacia;

g) la data e la sottoscrizione del giudice e dell'ausiliario che l'assiste.

2. Il decreto è nullo se l'imputato non è identificato in modo certo ovvero se manca o è insufficiente l'indicazione di uno dei requisiti previsti dal comma 1 lettere c) e f).

3. Tra la data del decreto e la data fissata per il giudizio deve intercorrere un termine non inferiore a venti giorni.

3-bis. Qualora si proceda per il reato di cui all'articolo 589, secondo comma, del codice penale, il termine di cui al comma 3 non può essere superiore a sessanta giorni.

4. Il decreto è notificato all'imputato contumace nonché all'imputato e alla persona offesa comunque non presenti alla lettura del provvedimento di cui al comma 1 dell'articolo 424 almeno venti giorni prima della data fissata per il giudizio.

Art. 430. Attività integrativa di indagine del pubblico ministero e del difensore.

1. Successivamente all'emissione del decreto che dispone il giudizio, il pubblico ministero e il difensore possono, ai fini delle proprie richieste al giudice del dibattimento, compiere attività integrativa di indagine, fatta eccezione degli atti per i quali è prevista la partecipazione dell'imputato o del difensore di questo.

2. La documentazione relativa all'attività indicata nel comma 1 è immediatamente depositata nella segreteria del pubblico ministero con facoltà delle parti di prenderne visione e di estrarne copia.

Art. 430-bis. Divieto di assumere informazioni.

1. E' vietato al pubblico ministero, alla polizia giudiziaria e al difensore assumere informazioni dalla persona ammessa ai sensi dell'articolo 507 o indicata nella richiesta di incidente probatorio o ai sensi dell'articolo 422, comma 2, ovvero nella lista prevista dall'articolo 468 e presentata dalle altre parti processuali. Le informazioni assunte in violazione del divieto sono inutilizzabili.

2. Il divieto di cui al comma 1 cessa dopo l'assunzione della testimonianza e nei casi in cui questa non sia ammessa o non abbia luogo. 
Art. 431. Fascicolo per il dibattimento.

1. Immediatamente dopo l'emissione del decreto che dispone il giudizio, il giudice provvede nel contraddittorio delle parti alla formazione del fascicolo per il dibattimento. Se una delle parti ne fa richiesta il giudice fissa una nuova udienza, non oltre il termine di quindici giorni, per la formazione del fascicolo. Nel fascicolo per il dibattimento sono raccolti:

a) gli atti relativi alla procedibilità dell'azione penale e all'esercizio dell'azione civile;

b) i verbali degli atti non ripetibili compiuti dalla polizia giudiziaria;

c) i verbali degli atti non ripetibili compiuti dal pubblico ministero e dal difensore;

d) i documenti acquisiti all'estero mediante rogatoria internazionale e i verbali degli atti non ripetibili assunti con le stesse modalità;

e) i verbali degli atti assunti nell'incidente probatorio;

f) i verbali degli atti, diversi da quelli previsti dalla lettera d), assunti all'estero a seguito di rogatoria internazionale ai quali i difensori sono stati posti in grado di assistere e di esercitare le facoltà loro consentite dalla legge italiana;

g) il certificato generale del casellario giudiziario e gli altri documenti indicati nell'articolo 236;

h) il corpo del reato e le cose pertinenti al reato, qualora non debbano essere custoditi altrove.

2. Le parti possono concordare l'acquisizione al fascicolo per il dibattimento di atti contenuti nel fascicolo del pubblico ministero, nonché della documentazione relativa all'attività di investigazione difensiva.

Art. 432. Trasmissione e custodia del fascicolo per il dibattimento.

1. Il decreto che dispone il giudizio è trasmesso senza ritardo, con il fascicolo previsto dall'articolo 431 e con l'eventuale provvedimento che abbia disposto misure cautelari in corso di esecuzione, alla cancelleria del giudice competente per il giudizio.

Art. 433. Fascicolo del pubblico ministero.

1. Gli atti diversi da quelli previsti dall'articolo 431 sono trasmessi al pubblico ministero con gli atti acquisiti all'udienza preliminare unitamente al verbale dell'udienza.

2. I difensori hanno facoltà di prendere visione ed estrarre copia, nella segreteria del pubblico ministero, degli atti raccolti nel fascicolo formato a norma del comma 1.

3. Nel fascicolo del pubblico ministero ed in quello del difensore è altresì inserita la documentazione dell'attività prevista dall'articolo 430 quando di essa le parti si sono servite per la formulazione di richieste al giudice del dibattimento e quest'ultimo le ha accolte”.

“Art. 507. Ammissione di nuove prove.

1. Terminata l'acquisizione delle prove, il giudice, se risulta assolutamente necessario, puó disporre anche di ufficio (190) l'assunzione di nuovi mezzi di prove.

1-bis. Il giudice puó disporre a norma del comma 1 anche dell'assunzione di mezzi di prova relativi agli atti acquisiti per il dibattimento a norma degli articoli 431, comma 2, e 493, comma 3”.

\section{d) Legislação esparsa (consulta nos sites www.leggiweb.it., www.comune.jesi.an.it,} www.infoleges.it e www.altalex.com).

o Lei n. ${ }^{\circ}$ 356, de 07 de agosto de 1992, publicada na "Gazzetta Ufficiale” de 07 de agosto de 1992, que converteu em lei o Decreto-Lei n. ${ }^{\circ}$ 306, de 08 de junho de 1992, e alterou dispositivos do Código de Processo Penal com o objetivo de combater a criminalidade mafiosa:

"Art. 3. Verbali di prove di altri procedimenti e acquisizione di documenti. 
1. L'articolo 238 del codice di procedura penale è sostituito dal seguente:

'Ar. 238. Verbali di prove di altri procedimenti.

1. È ammessa l'acquisizione di verbali di prove di altro procedimento penale se si tratta di prove assunte nell'incidente probatorio o nel dibattimento.

2. È ammessa l'acquisizione di verbali di prove assunte in um giudizio civile definito con sentenza che abbia acquistato autoritá di cosa giudicata.

3. È comunque ammessa l'acquisizione della documentazione di atti che anche per cause sopravvenute non sono ripetibili.

4. Al di fuori dei casi previsti dai commi 1, 2 e 3, i verbali di dichiarazioni possono essere utilizzati nel dibattimento se le parti vi consentono; in mancanza di consenso, detti verbali possono essere utilizzati a norma degli articoli 500 e 503.

5. Salvo quanto previsto dall'articolo 190-bis, resta fermo il diritto delle parti di ottenere a norma dell'articolo 190 l'esame delle persone le cui dichiarazioni sono state acquisite a norma dei commi 1, 2 e 4 del presente articolo.'

2. Dopo l'articolo 238 del codice di procedura penale è inserito il seguente:

'Ar. 238-bis. Sentenze irrevocabili.

1. Fermo quanto previsto dall'articolo 236, le sentenze divenute irrevocabili possono essere acquisite ai fini della prova di fatto in esse accertato e sono valutate a norma degli articoli 187 e 192, comma 3”.

o Lei n. ${ }^{\circ}$ 332, de 08 de agosto de 1995, publicada na “Gazzetta Ufficiale” de 08 de agosto de 1995, que altera dispositivos do Código de Processo Penal:

“Art. 22.

1. All'articolo 38 delle norme di attuazione, di coordinamento e transitorie del codice di procedura penale, approvate con decreto legislativo 28 luglio 1989, n. 271, sono aggiunti, in fine, i seguenti commi:

'2-bis. Il difensore della persona sottoposta alle indagini o della persona offesa puó presentare direttamente al giudice elementi che egli reputa rilevanti ai fini della decisione da adottare.

2-ter. La documentazione presentata al giudice è inserita nel fascicolo relativo agli atti di indagine in originale o in copia, se la persona sottoposta alle indagini ne richiede la restituzione’”.

o Lei n. ${ }^{\circ}$ 479, de 16 de dezembro de 1999, publicada na “Gazzetta Ufficiale” de 18 de dezembro de 1999, que altera dispositivos do Código de Processo Penal:

“Art. 17.

1. All'articolo 405, comma 2, ed all'articolo 407, comma 3, del codice di procedura penale, sono premesse le seguenti parole: 'Salvo quanto previsto dall'articolo 415-bis'.

2. Dopo l'articolo 415 del codice di procedura penale è inserito il seguente:

'Art. 415-bis. Avviso all'indagato della conclusione delle indagini preliminari.

1. Prima della scadenza del termine previsto dal comma 2 dell'articolo 405, anche se prorogato, il pubblico ministero, se non deve formulare richiesta di archiviazione ai sensi degli articoli 408 e 411, fa notificare alla persona sottoposta alle indagini e al difensore avviso della conclusione delle indagini preliminari.

2. L'avviso contiene la sommaria enunciazione del fatto per il quale si procede, delle norme di legge che si assumono violate, della data e del luogo del fatto con l'avvertimento che la documentazione relativa alle indagini espletate e' depositata presso la segreteria del pubblico ministero e che l'indagato e il suo difensore hanno facoltà di prenderne visione ed estrarne copia.

3. L'avviso contiene altresì l'avvertimento che l'indagato ha facolta' entro il termine di venti giorni, di presentare memorie, produrre documenti, depositare documentazione relativa ad investigazioni del difensore, chiedere al pubblico ministero il compimento di atti di indagine, nonchè di presentarsi per rilasciare 
dichiarazioni ovvero chiedere di essere sottoposto ad interrogatorio. Se l'indagato chiede di essere sottoposto ad interrogatorio il pubblico ministero deve procedervi.

4. Quando il pubblico ministero, a seguito delle richieste dell'indagato, dispone nuove indagini, queste devono essere compiute entro trenta giorni dalla presentazione, della richiesta. Il termine può essere prorogato dal giudice per le indagini preliminari, su richiesta dei pubblico ministero, per una sola volta e per non piú di sessanta giorni.

5. Le dichiarazioni rilasciate dall'indagato, l'interrogatorio del medesimo ed i nuovi atti di indagine del pubblico ministero, previsti dai commi 3 e 4, sono utilizzabili se compiuti entro il termine stabilito dal comma 4, ancorchè sia decorso il termine stabilito dalla legge o prorogato dal giudice per l'esercizio dell'azione penale o per la richiesta di archiviazione'.

3. All'articolo 416, comma 1, del codice di procedura penale le parole da: 'dall'invito' alla fine sono sostituite dalle seguenti: 'dall'avviso, previsto dall'articolo 415-bis, nonchè dall'invito a presentarsi per rendere l'interrogatorio ai sensi dell'articolo 375, comma 3, qualora la persona sottoposta alle indagini abbia chiesto di essere sottoposta ad interrogatorio entro il termine di cui all'articolo 415-bis, comma 3”.

o Lei n. ${ }^{\circ}$ 397, de 07 de dezembro de 2000, publicada na "Gazzetta Ufficiale" de 3 de janeiro de 2001, que traz disposições em matéria de investigação defensiva:

"Capo I

MODIFICHE AL CODICE DI PROCEDURA PENALE

Art. 1

1. All'articolo 103 del codice di procedura penale sono apportate le seguenti modificazioni:

a) al comma 2, le parole: "Presso i difensori e i consulenti tecnici non si può procedere a sequestro" sono sostituite dalle seguenti: "Presso i difensori e gli investigatori privati autorizzati e incaricati in relazione al procedimento, nonché presso i consulenti tecnici non si può procedere a sequestro";

b) al comma 5, dopo le parole: "dei difensori," sono inserite le seguenti: "degli investigatori privati autorizzati e incaricati in relazione al procedimento, dei".

Art. 2.

1. All'articolo 116 del codice di procedura penale, dopo il comma 3 è aggiunto il seguente: "3-bis. Quando il difensore, anche a mezzo di sostituti, presenta all'autorità giudiziaria atti o documenti, ha diritto al rilascio di attestazione dell'avvenuto deposito, anche in calce ad una copia".

Art. 3.

1. All'articolo 197, comma 1, lettera d), del codice di procedura penale, sono aggiunte, in fine, le seguenti parole: "nonché il difensore che abbia svolto attività di investigazione difensiva e coloro che hanno formato la documentazione delle dichiarazioni e delle informazioni assunte ai sensi dell'articolo 391-ter".

Art. 4.

1. La lettera b) del comma 1 dell'articolo 200 del codice di procedura penale è sostituita dalla seguente:

"b) gli avvocati, gli investigatori privati autorizzati, i consulenti tecnici e i notai;".

Art. 5.

1. All'articolo 233 del codice di procedura penale, dopo il comma 1 sono inseriti i seguenti:

"1-bis. Il giudice, a richiesta del difensore, può autorizzare il consulente tecnico di una parte privata ad esaminare le cose sequestrate nel luogo in cui esse si trovano, ad intervenire alle ispezioni, ovvero ad esaminare l'oggetto delle ispezioni alle quali il consulente non è intervenuto. Prima dell'esercizio dell'azione penale l'autorizzazione è disposta dal pubblico ministero a richiesta del difensore. Contro il decreto che respinge la richiesta il difensore può proporre opposizione al giudice, che provvede nelle forme di cui all'articolo 127. 
1-ter. L'autorità giudiziaria impartisce le prescrizioni necessarie per la conservazione dello stato originario delle cose e dei luoghi e per il rispetto delle persone".

Art. 6.

1. All'articolo 292, comma 2-ter, del codice di procedura penale, le parole: "all'articolo 38 delle norme di attuazione, di coordinamento e transitorie" sono sostituite dalle seguenti: "all'articolo 327-bis".

Art. 7.

1. Dopo l'articolo 327 del codice di procedura penale è inserito il seguente:

"Art. 327-bis. Attività investigativa del difensore.

1. Fin dal momento dell'incarico professionale, risultante da atto scritto, il difensore ha facoltà di svolgere investigazioni per ricercare ed individuare elementi di prova a favore del proprio assistito, nelle forme e per le finalità stabilite nel titolo VI-bis del presente libro.

2. La facoltà indicata al comma 1 può essere attribuita per l'esercizio del diritto di difesa, in ogni stato e grado del procedimento, nell'esecuzione penale e per promuovere il giudizio di revisione.

3. Le attività previste dal comma 1 possono essere svolte, su incarico del difensore, dal sostituto, da investigatori privati autorizzati e, quando sono necessarie specifiche competenze, da consulenti tecnici".

Art. 8.

1. Dopo l'articolo 334 del codice di procedura penale è inserito il seguente:

"Art. 334-bis. Esclusione dell'obbligo di denuncia nell'ambito dell'attività di investigazioni difensiva.

1. Il difensore e gli altri soggetti di cui all'articolo 391-bis non hanno obbligo di denuncia neppure relativamente ai reati dei quali abbiano avuto notizia nel corso delle attività investigative da essi svolte".

Art. 9.

1. Dopo il primo periodo del comma 1 dell'articolo 362 del codice di procedura penale è inserito il seguente: "Alle persone già sentite dal difensore o dal suo sostituto non possono essere chieste informazioni sulle domande formulate e sulle risposte date".

Art. 10.

1. All'articolo 366, comma 1, del codice di procedura penale è aggiunto, in fine, il seguente periodo: "Il difensore ha facoltà di esaminare le cose sequestrate nel luogo in cui esse si trovano e, se si tratta di documenti, di estrarne copia".

2. Il comma 2 dell'articolo 366 del codice di procedura penale è sostituito dal seguente:

"2. Il pubblico ministero, con decreto motivato, può disporre, per gravi motivi, che il deposito degli atti indicati nel comma 1 e l'esercizio della facoltà indicata nel terzo periodo dello stesso comma siano ritardati, senza pregiudizio di ogni altra attività del difensore, per non oltre trenta giorni. Contro il decreto del pubblico ministero la persona sottoposta ad indagini ed il difensore possono proporre opposizione al giudice, che provvede ai sensi dell'articolo 127".

Art. 11.

1. Dopo il titolo VI del libro quinto del codice di procedura penale è inserito il seguente:

"Titolo VI-bis.

\section{INVESTIGAZIONI DIFENSIVE}

[estas disposições foram transcritas no tópico sobre o Código de Processo Penal]

Art. 12.

1. All'articolo 409, comma 2, del codice di procedura penale, il terzo periodo è sostituito dal seguente: "Fino al giorno dell'udienza gli atti restano depositati in cancelleria con facoltà del difensore di estrarne copia".

Art. 13.

1. All'articolo 419, comma 3, del codice di procedura penale, le parole: "comunicato al pubblico ministero" sono soppresse. 
Art. 14.

1. L'articolo 430 del codice di procedura penale è sostituito dal seguente:

"Art. 430. Attività integrativa di indagine del pubblico ministero e del difensore.

1. Successivamente all'emissione del decreto che dispone il giudizio, il pubblico ministero e il difensore possono, ai fini delle proprie richieste al giudice del dibattimento, compiere attività integrativa di indagine, fatta eccezione degli atti per i quali è prevista la partecipazione dell'imputato o del difensore di questo.

2. La documentazione relativa all'attività indicata nel comma 1 è immediatamente depositata nella segreteria del pubblico ministero con facoltà delle parti di prenderne visione e di estrarne copia".

Art. 15.

1. All'articolo 431, comma 1, lettera c), del codice di procedura penale, sono aggiunte, in fine, le parole: "e dal difensore".

Art. 16.

1. All'articolo 433, comma 3, del codice di procedura penale, dopo le parole: "pubblico ministero" sono inserite le seguenti: "ed in quello del difensore".

Art. 17.

1. All'articolo 495 del codice di procedura penale, dopo il comma 4 è aggiunto il seguente:

"4-bis. Nel corso dell'istruzione dibattimentale ciascuna delle parti può rinunziare, con il consenso dell'altra parte, all'assunzione delle prove ammesse a sua richiesta".

Art. 18.

1. All'articolo 512, comma 1, del codice di procedura penale, dopo le parole: "pubblico ministero" sono inserite le seguenti: ", dai difensori delle parti private".

\section{Capo II}

\section{MODIFICHE AL CODICE PENALE}

Art. 19.

1. All'articolo 371-bis del codice penale, dopo il secondo comma è aggiunto il seguente:

"Le disposizioni di cui ai commi primo e secondo si applicano, nell'ipotesi prevista dall'articolo 391-bis, comma 10, del codice di procedura penale, anche quando le informazioni ai fini delle indagini sono richieste dal difensore".

Art. 20.

1. Dopo l'articolo 371-bis del codice penale è inserito il seguente:

"Art. 371-ter. False dichiarazioni al difensore.

Nelle ipotesi previste dall'articolo 391-bis, commi 1 e 2, del codice di procedura penale, chiunque, non essendosi avvalso della facoltà di cui alla lettera d) del comma 3 del medesimo articolo, rende dichiarazioni false è punito con la reclusione fino a quattro anni.

Il procedimento penale resta sospeso fino a quando nel procedimento nel corso del quale sono state assunte le dichiarazioni sia stata pronunciata sentenza di primo grado ovvero il procedimento sia stato anteriormente definito con archiviazione o con sentenza di non luogo a procedere".

Art. 21.

1. Dopo l'articolo 379 del codice penale è inserito il seguente:

"Art. 379-bis. Rivelazione di segreti inerenti a un procedimento penale.

Salvo che il fatto costituisca più grave reato, chiunque rivela indebitamente notizie segrete concernenti un procedimento penale, da lui apprese per avere partecipato o assistito ad un atto del procedimento stesso, è punito con la reclusione fino a un anno. La stessa pena si applica alla persona che, dopo avere rilasciato 
dichiarazioni nel corso delle indagini preliminari, non osserva il divieto imposto dal pubblico ministero ai sensi dell'articolo 391-quinquies del codice di procedura penale".

Art. 22.

1. All'articolo 375 del codice penale, dopo le parole: "371-bis," sono inserite le seguenti: "371-ter,".

2. All'articolo 376, primo comma, del codice penale, dopo le parole: "371-bis," sono inserite le seguenti: "371-ter,".

3. All'articolo 377, primo comma, del codice penale, dopo le parole: "davanti all'autorità giudiziaria ovvero" sono inserite le seguenti: "alla persona richiesta di rilasciare dichiarazioni dal difensore nel corso dell'attività investigativa, o alla persona chiamata" e dopo le parole: "371-bis," sono inserite le seguenti: "371-ter,".

4. All'articolo 384 del codice penale sono apportate le seguenti modificazioni:

a) al primo comma, dopo le parole: "371-bis," sono inserite le seguenti: "371-ter,";

b) al secondo comma, dopo le parole: "371-bis," sono inserite le seguenti: "371-ter,".

Capo III

NORME DI ATTUAZIONE

Art. 23.

1. L'articolo 38 delle norme di attuazione, di coordinamento e transitorie del codice di procedura penale, approvate con decreto legislativo 28 luglio 1989, n. 271, come modificato dall'articolo 22 della legge 8 agosto 1995, n. 332, è abrogato.

Art. 24.

1. All'articolo 222 delle norme di attuazione, di coordinamento e transitorie del codice di procedura penale, approvate con decreto legislativo 28 luglio 1989, n. 271, sono apportate le seguenti modificazioni:

a) al comma 1, le parole: "nell'articolo 38" sono sostituite dalle seguenti: "nell'articolo 327-bis del codice";

b) il comma 4 è sostituito dal seguente:

"4. Ai fini di quanto disposto dall'articolo 103, commi 2 e 5, del codice, il difensore comunica il conferimento dell'incarico previsto dal comma 2 del presente articolo all'autorità giudiziaria procedente".

Art. 25.

1. Le disposizioni regolamentari di cui all'articolo 206 delle norme di attuazione, di coordinamento e transitorie del codice di procedura penale, approvate con decreto legislativo 28 luglio 1989, n. 271, sono modificate conformemente a quanto previsto dalla presente legge”.

e) Regras de comportamento do penalista nas investigações defensivas - texto aprovado, em 14 de julho de 2001, pela Unione Camere Penali Italiane (consulta no site www.camerepenali.it).

\section{"REGOLE GENERALI}

Articolo 1. Norme deontologiche applicabili.

1. Nello svolgimento delle investigazioni difensive il difensore osserva le norme del Codice deontologico forense, con particolare riferimento ai doveri di probità, fedeltà, competenza e verità, nonché le ulteriori norme degli articoli che seguono, nel rispetto del principio di lealtà processuale e a garanzia della reale dialettica nel procedimento.

2. Nessuna distinzione circa i doveri professionali in materia di investigazioni difensive è consentita tra difensore di fiducia e difensore d'ufficio.

Articolo 2. Legittimazione alle investigazioni difensive. 
1. Il difensore è legittimato a svolgere investigazioni difensive sin dal momento della nomina senza necessità di specifico mandato ed indipendentemente dal deposito dell'atto di nomina presso l'autorità giudiziaria.

2. Il mandato con sottoscrizione autenticata, necessario per svolgere l'attività investigativa preventiva prevista dall'articolo 391-nonies del codice di procedura penale, indica i fatti ai quali si riferisce in modo sintetico al solo fine della individuazione dell'oggetto di tale attività, con esclusione di ogni riferimento ad ipotesi di reato.

3. La previsione del comma 2 non si applica al mandato rilasciato dalla persona offesa dal reato.

4. Le disposizioni sull'attività investigativa preventiva si intendono applicabili, oltre che per l'eventualità che si instauri un procedimento penale, anche per le ipotesi:

a) che possa essere richiesta la riapertura delle indagini preliminari dopo il decreto di archiviazione;

b) che possa essere richiesta la revoca della sentenza di non luogo a procedere;

c) che possa essere richiesta la revisione;

d) che possano essere instaurati procedimenti davanti al giudice dell'esecuzione o alla magistratura di sorveglianza.

Articolo 3. Dovere di valutazione.

1. Il difensore, fin dal momento dell'incarico e successivamente fino alla sua conclusione, ha il dovere di valutare, in relazione alle esigenze e agli obbiettivi della difesa, la necessità o l'opportunità di svolgere investigazioni, sia ai fini delle determinazioni inerenti alla difesa stessa, sia per l'ipotesi di un impiego dei risultati nel procedimento, secondo le forme, i tempi e i modi previsti dalla legge.

Articolo 4. Direzione delle investigazioni.

1. La decisione di iniziare e terminare le investigazioni, le scelte sull'oggetto, sui modi e sulle forme di esse competono al difensore [, in accordo con l'eventuale condifensore].

2. Quando non svolge di persona le investigazioni e, secondo la previsione del comma 3 dell'articolo 327-bis del codice di procedura penale, si avvale di sostituti, investigatori privati autorizzati e consulenti tecnici, il difensore dà, anche oralmente, le direttive necessarie, cui i sostituti e tali ausiliari hanno il dovere di attenersi, fermi tutti i loro obblighi previsti dalla legge.

3. Nel dare le direttive il difensore rammenta gli obblighi indicati al comma 2, con particolare riguardo a quelli relativi agli avvertimenti alle persone con le quali occorre conferire, agli accessi ai luoghi e alla ispezione delle cose, alla eventuale redazione di verbali, al segreto sugli atti e sul loro contenuto, nonché a quello di riferirgli tempestivamente i risultati dell'attività svolta.

4. Ai fini dell'esercizio dell'incarico il difensore dà ai sostituti e agli ausiliari le informazioni necessarie e può fornire a essi, anche nell'ipotesi di segretazione dell'atto, copie di atti e documenti, in ogni caso con vincolo di segreto.

5. L'incarico agli investigatori privati e ai consulenti tecnici è conferito con atto scritto, nel quale, fermo quanto previsto al comma 3, il difensore indica i loro doveri di:

a) osservare le disposizioni di legge, in particolare quelle sulle investigazioni difensive e sulla tutela dei dati personali;

b) comunicare le notizie e i risultati delle investigazioni e rimetterne l'eventuale documentazione soltanto al difensore che ha conferito l'incarico o al suo sostituto;

c) salva specifica autorizzazione scritta del difensore, rifiutare ogni altro incarico relativo o connesso alla vicenda alla quale attiene quello conferito.

Articolo 5. Informazioni preventive tra difensore e persona assistita.

1. Nell'ambito dei rapporti informativi con la persona assistita al fine di coordinare la difesa tecnica e l'autodifesa, il difensore, oltre ad attingere eventuali notizie utili per apprezzare la necessità o l'opportunità di svolgere investigazioni difensive, valuta la esigenza di comunicare tempestivamente alla persona medesima tale apprezzamento, anche con riguardo alle spese prevedibili per le relative attività.

Articolo 6. Dovere di segretezza, limiti di utilizzazione, conservazione della documentazione. 
1. Il difensore ha il dovere di mantenere il segreto professionale sugli atti delle investigazioni difensive e sul loro contenuto, finché non ne faccia uso nel procedimento, salva la rivelazione per giusta causa nell'interesse del proprio assistito.

2. In ogni caso, il difensore utilizza la documentazione degli atti delle investigazioni difensive e i relativi contenuti nei soli limiti e nei tempi in cui siano necessari all'esercizio della difesa.

3. Il difensore cura di conservare scrupolosamente e riservatamente la documentazione, anche informale, delle investigazioni difensive per tutto il tempo in cui egli ritiene che possa essere necessaria o utile per l'esercizio della difesa.

Articolo 7. Rimborso delle spese documentate.

1. E' fatto divieto al difensore, al suo sostituto, agli ausiliari e ai loro collaboratori di corrispondere compensi o indennità, sotto qualsiasi forma, alle persone che ai fini delle investigazioni difensive danno informazioni o si prestano al compimento di accessi ai luoghi, ispezione di cose, rilievi, consegna o esame di documenti e in genere alla esecuzione di atti .

2. Alle persone indicate al comma 1 è dovuto il solo rimborso delle spese documentate.

\section{REGOLE PER LE INDAGINI DA FONTI DICHIARATIVE}

Articolo 8. Ricerca e individuazione di fonti.

1. Il difensore, il sostituto e gli ausiliari incaricati procedono senza formalità alla individuazione delle persone che possono riferire circostanze utili alle investigazioni difensive. In ogni caso, nello svolgimento dell'attività di individuazione di tali persone, informano sempre le persone interpellate della propria qualità, senza necessità di rivelare il nome dell'assistito.

2. Nello stesso modo si procede alla individuazione delle altre fonti di prova e, in genere, delle altre fonti di notizie utili alle indagini.

Articolo 9. Avvertimenti.

1. I soggetti della difesa, nell'informare le persone interpellate della loro qualità, indicano la vicenda in ordine alla quale svolgono investigazioni, senza necessariamente rivelare il nome dell'assistito.

2. Oltre quanto è previsto dal comma 3 dell'articolo 391-bis del codice di procedura penale, invitano le persone interpellate a dichiarare se si trovano in una delle situazioni di incompatibilità previste dall'articolo 197 comma 1, lettere c) e d) del codice di procedura penale.

3. Inoltre, informano le persone interpellate che, se si avvarranno della facoltà di non rispondere, potranno essere chiamate ad una audizione davanti al pubblico ministero ovvero a rendere un esame testimoniale davanti al giudice, ove saranno tenute a rispondere anche alle domande del difensore.

4. Se si tratta di persone sottoposte a indagine o imputate nello stesso procedimento o in altro procedimento connesso o collegato ai sensi dell'articolo 210 del codice di procedura penale, le informano che, se si avvarranno della facoltà di non rispondere, potranno essere chiamate a rendere esame davanti al giudice in incidente probatorio.

5. Se si tratta di prossimi congiunti di un imputato o di una persona sottoposta alle indagini, li avvertono che, anche in ragione di tale rapporto, hanno facoltà di astenersi dal rispondere o dal rendere la dichiarazione nei casi previsti dalla legge.

6. I soggetti della difesa possono altresì ricordare che ogni persona può utilmente concorrere alla ricostruzione dei fatti e all'accertamento della verità in un procedimento penale anche rendendo dichiarazioni al difensore.

7. Quando i soggetti della difesa procedono con invito scritto, gli avvertimenti previsti dalla legge e dalle norme deontologiche, se non sono contenuti nell'invito stesso, possono essere dati oralmente, ma devono comunque precedere l'atto.

Articolo 10. Inviti e avvisi: casi particolari.

1. Per conferire, chiedere e ricevere dichiarazioni scritte o assumere informazioni da documentare dalla persona offesa dal reato i soggetti della difesa procedono mediante un invito scritto. 
2. Se la persona offesa è assistita da un difensore, a costui è dato avviso almeno ventiquattro ore prima. Se non risulta assistita da un difensore, nell'invito è indicata l'opportunità che comunque un difensore sia consultato e intervenga all'atto.

3. La disposizione del comma 1 si applica anche quando si intende chiedere e ricevere una dichiarazione scritta o assumere informazioni da documentare da una persona minore. L'invito è comunicato anche a chi esercita la potestà dei genitori, con l'avviso della facoltà di intervenire all'atto.

4. Ai fini dell'applicazione del comma 5 dell'articolo 391-bis del codice di procedura penale, al difensore d'ufficio, nominato per l'atto, che ne faccia richiesta, è dato un termine non inferiore a quelli previsti dall'articolo 108 del codice di procedura penale.

Articolo 11. Rapporti tra difensore e assistito nell'ambito delle investigazioni difensive.

1. E' fatto divieto ai soggetti della difesa di applicare le disposizioni degli articoli 391-bis e 391-ter del codice di procedura penale nei confronti della persona assistita.

2. Il difensore e il sostituto, anche, se del caso, con la presenza degli ausiliari, scambiano liberamente e riservatamente con il proprio assistito, nelle forme e nei tempi opportuni, le informazioni necessarie ad assicurare un coordinato esercizio della difesa tecnica e dell'autodifesa su tutti i temi ritenuti utili. Inoltre, lo consigliano e lo assistono in relazione agli atti, orali o scritti, nonché alle scelte che egli compie personalmente nel procedimento.

Articolo 12. Garanzie di genuinità delle dichiarazioni.

1. Il difensore o il suo sostituto danno tutte le disposizioni necessarie per realizzare condizioni idonee ad assicurare la genuinità delle dichiarazioni.

Articolo 13. Documentazione.

1. Le informazioni assunte dal difensore, secondo le previsioni degli articoli 391-bis comma 2 e 391-ter comma 3 del codice di procedura penale, sono documentate in forma integrale. Quando è disposta la riproduzione almeno fonografica possono essere documentate in forma riassuntiva.

2. Nel verbale, redatto con le modalità previste al comma 1, sono specificamente indicati i mezzi impiegati. Esso è sottoscritto da tutte le persone presenti ed è conservato dal difensore ai sensi del comma 6 dell'articolo 3 .

3. Il difensore non è tenuto a rilasciare copia del verbale alla persona che ha reso informazioni né al suo difensore.

\section{DISPOSIZIONI RELATIVE AGLI ACCESSI AI LUOGHI, ALLA ISPEZIONE DI COSE}

\section{E AGLI ACCERTAMENTI IRRIPETIBILI}

Articolo 14. Doveri negli accessi ai luoghi e nella ispezione di cose.

1. Il difensore, il sostituto e gli ausiliari, che procedono agli atti indicati nell'articolo 391-sexies del codice di procedura penale, anche quando non redigono un verbale, documentano nelle forme più opportune lo stato dei luoghi e delle cose, procurando che nulla sia mutato, alterato o disperso.

2. Oltre a quanto è previsto dal comma 2 dell'articolo 391-septies del codice di procedura penale, quando intendono compiere un accesso a luogo privato o non aperto al pubblico, i soggetti della difesa, nel richiedere il consenso di chi ne ha la disponibilità, lo avvertono della propria qualità, della natura dell'atto da compiere e della possibilità che, ove non sia prestato il consenso, l'atto sia autorizzato dal giudice.

3. Gli avvertimenti indicati al comma 2 sono documentati almeno mediante annotazione.

Articolo 15. Dovere di assicurare il contraddittorio negli accertamenti tecnici irripetibili.

1. Quando i soggetti della difesa intendono compiere accertamenti tecnici irripetibili, a cura del difensore o del sostituto è dato avviso senza ritardo a tutti coloro nei confronti dei quali l'atto può avere effetto e dei quali si abbia conoscenza. 
Articolo 16.

1. Sono abrogate tutte le norme deontologiche relative alle investigazioni difensive, approvate a Catania il 30 marzo 1996.

2. Entro il 31 maggio 2002 saranno valutati i risultati della applicazione delle presenti norme e approvate eventuali norme integrative, modificative o soppressive.

3. Le presenti norme sono trasmesse subito al Consiglio Nazionale Forense per tutte le determinazioni di competenza”. 


\section{BIBLIOGRAFIA}

ABADE, Denise Neves. Garantias do Processo Penal Acusatório - o novo papel do Ministério Público no Processo Penal de partes. São Paulo: Renovar, 2005.

ALMEIDA, Joaquim Canuto Mendes de. Princípios fundamentais do processo penal. São Paulo: Revista dos Tribunais, 1973.

Processo penal, ação e jurisdição. São Paulo: Revista dos Tribunais, 1975.

AMODIO, Ennio. "Vitórias e derrotas da cultura dos juristas na elaboração do novo Código de Processo Penal” in Revista Brasileira de Ciências Criminais, n. ${ }^{\circ}$ 25, jan./mar. de 1999, pp. 09/22.

. "Il processo penale tra disregazione e recupero del sistema” in L'indice penale, Ano VI, n. ${ }^{\circ}$ 1, gennaio/aprile 2003, pp. 07/18.

APRILE, Ercole e SILVESTRI, Pietro. La formazione della prova penale - dopo le leggi sulle indagini difensive e sul "giusto processo”. Milano: Giuffrè, 2002.

. Le indagini preliminari e l'archiviazione (artt. 326-415-bis cod. proc. pen.). Milano: Giuffrè, 2004.

ARAÚJO CINTRA, Antonio Carlos; GRINOVER, Ada Pellegrini e DINAMARCO, Cândido Rangel. Teoria Geral do Processo. 14ª ed.. São Paulo: Malheiros, 1998.

AROCA, Juan Montero. Principios del Proceso Penal - Una explicación basada en la razón. Valencia: Tirant lo Blanch, 1997.

AZEVEDO, André Boiani e BALDAN, Édson Luís. “A preservação do devido processo legal pela investigação defensiva (ou do direito de defender-se provando)” in Boletim do Instituto Brasileiro de Ciências Criminais, n. ${ }^{\circ}$ 137, abril/2004, pp. 06/08.

BADARÓ, Gustavo Henrique Righi Ivahy. Ônus da prova no processo penal. São Paulo: Revista dos Tribunais, 2003.

BARROS, Marco Antonio de. A busca da verdade no Processo Penal. São Paulo: Revista dos Tribunais, 2002. 
BELLOQUE, Juliana Garcia. Sigilo bancário: análise crítica da LC 105/2001. São Paulo: Revista dos Tribunais, 2003.

CALABRICH, Bruno. Investigação criminal pelo Ministério Público: fundamentos e limites constitucionais. São Paulo: Revista dos Tribunais, 2007.

CARNAÚBA, Maria Cecília Pontes. Prova Ilícita. São Paulo: Saraiva, 2000.

CARNELUTTI, Francesco. Lecciones sobre el Proceso Penal. Trad. Santiago Sentis Melendo. Buenos Aires: Bosch, 1950, vol. II. . "Poner en su puesto al Ministerio Publico" in Cuestiones sobre el Proceso Penal. Trad. Santiago Sentis Melendo. Buenos Aires: Librería el Foro, 1960. . Direito Processual Penal. Campinas: Peritas, 2001, v. 2.

CESETTI, Marco. “Investigazioni difensive: luci ed ombre”. Disponível na internet: “www.giuridicamente.com/investigazioni”. Acesso em 22 de setembro de 2008.

CHIAVARIO, Mario. La Riforma del Processo Penale - Appunti sul Nuovo Codice. $2^{\mathrm{a}}$ ed.. Torino: Utet, 1990.

CHOUKR, Fauzi Hassan. Garantias constitucionais na investigação criminal. $2^{\mathrm{a}}$ ed.. Rio de Janeiro: Lumen Juris, 2001.

. “O relacionamento entre o Ministério Público e a Polícia Judiciária no processo penal acusatório” in Processo Penal e Estado de Direito. CHOUKR, Fauzi Hassan e AMBOS, Kai (orgs.). Campinas: Edicamp, 2002, pp. 149/72.

COLOMER, Juan-Luis Gómez. "La instrucción del Proceso Penal por el Ministerio Fiscal: aspectos estructurales a la luz del derecho comparado" in Cuadernos de Doctrina y Jurisprudencial Penal, n. ${ }^{\circ}$ 07, publicación de Ad-Hoc S.R.L, Buenos Aires, pp. 901/36.

. “A investigação criminal: problemas atuais e perspectivas de unificação internacional” in Processo Penal e Estado de Direito. CHOUKR, Fauzi Hassan e AMBOS, Kai (orgs.). Campinas: Edicamp, 2002, pp. 199/244. 
. "Estado Democrático e Modelo Policial: uma proposta de estrutura para obter uma investigação eficaz do crime” in Polícia e Estado de Direito na América Latina. CHOUKR, Fauzi Hassan e AMBOS, Kai (orgs.). Rio de Janeiro: Lumen Juris, 2004, pp. 93/109.

- "La investigacion del crimen en el proceso penal ante el Tribunal Penal Internacional” in Revista Penal, n. ${ }^{\circ}$ 12, publicación semestral de LA LEY S/A, en colaboración con las Universidades de Huelva, Salamanca, Castilla-La Mancha y Pablo de Olavide, Sevilla, pp. 72/97.

COSTA, Paula Bajer Fernandes Martins da. Igualdade no Direito Processual Penal Brasileiro. São Paulo: Revista dos Tribunais, 2001.

COUTINHO, Jacinto Nelson de Miranda. “As reformas parciais do CPP e a gestão da prova: segue o princípio inquisitivo" in Boletim do Instituto Brasileiro de Ciências Criminais, n. ${ }^{\circ}$ 188, julho/2008, pp. 11/13.

CRUZ, Rogério Schietti Machado. “Com a palavra, as partes” in Boletim do Instituto Brasileiro de Ciências Criminais, n. ${ }^{\circ}$ 188, julho/2008, pp. 17/18.

DALIA, Andrea Antonio e FERRAIOLI, Marzia. Manuale di Diritto Processuale Penale. Milano: CEDAM, 2001.

DAVID, René. Os grandes sistemas do Direito contemporâneo. Tradução de Hermínio A. Carvalho. São Paulo: Martins Fontes, 1998.

DEZEM, Guilherme Madeira. Da prova penal: tipo processual, provas típicas e atípicas. Campinas: Millennium, 2008.

DINAMARCO, Cândido Rangel. “O princípio do contraditório” in Revista PGE, São Paulo, n. ${ }^{\circ} 19$, 1981/82, pp. 29 e segs..

FERRAJOLI, Luigi. Direito e razão: teoria do garantismo penal. São Paulo: Revista dos Tribunais, 2002.

GARCÍA, Nicolás Rodrígues. La Justicia Penal Negociada. Experiencias de Derecho Comparado. Salamanca: Ediciones Universidad de Salamanca, 1997. 
GATTO, Pietro. Le investigazioni preventive del difensore. Milano: Giuffrè, 2003.

GIOSTRA, Glauco. "Problemi irrisolti e nuove prospettive per il diritto di difesa: dalla registrazione delle notizie di reato alle indagini difensive” in Politica del Diritto, Ano XXVIII, n. ${ }^{\circ}$ 2, junho 1997, pp. 147/89.

GOMES, Mariângela Gama de Magalhães. O princípio da proporcionalidade no direito penal. São Paulo: Revista dos Tribunais, 2003.

GOMES FILHO, Antonio Magalhães. Direito à prova no processo penal. São Paulo: Revista dos Tribunais, 1997.

. A motivação das decisões penais. São Paulo: Revista dos Tribunais, 2001.

- "Notas sobre a terminologia da prova (reflexos no processo penal brasileiro)” in Estudos em homenagem à Professora Ada Pellegrini Grinover. YARSHEL, Flávio Luiz e MORAES, Maurício Zanoide de (orgs.). São Paulo: DPJ, 2005.

. "Provas - Lei 11.690, de 09.06.2008" in As reformas no Processo

Penal: as novas Leis de 2008 e os projetos de reforma. MOURA, Maria Thereza Rocha de Assis (org.). São Paulo: Revista dos Tribunais, 2008, pp. 246/97.

GRECO FILHO, Vicente. Tutela Constitucional das liberdades. São Paulo: Saraiva, 1989.

GRINOVER, Ada Pellegrini. “As garantias constitucionais do processo” in Novas tendências do direito processual. Rio de Janeiro: Forense Universitária, 1990.

. “A iniciativa instrutória do Juiz no Processo Penal acusatório” in Revista Brasileira de Ciências Criminais, n. ${ }^{\circ}$ 27, jul./set. de 1999, pp. 71/79.

. “Que juízes são esses?” in Boletim do Instituto Brasileiro de Ciências Criminais, n. ${ }^{\circ}$ 25, janeiro/1995, pp. 01/02.

. “Que juiz inquisidor é esse?” in Boletim do Instituto Brasileiro de Ciências Criminais, n. ${ }^{\circ}$ 30, junho/1995, p. 01. 
GRINOVER, Ada Pellegrini; SCARANCE FERNANDES, Antonio e GOMES FILHO, Antonio Magalhães. As nulidades no processo penal. $8^{\mathrm{a}}$ ed.. São Paulo: Revista dos Tribunais, 2004.

GRINOVER, Ada Pellegrini; SCARANCE FERNANDES, Antonio; GOMES FILHO, Antonio Magalhães e GOMES, Luiz Flávio. Juizados Especiais Criminais. $3^{\text {a }}$ ed.. São Paulo: Revista dos Tribunais, 2000.

GUERINI, Umberto. “Sulla qualifica soggettiva dell'avocato che svolge indagini difensive”. Disponível na internet: “www.dirittoegiustiziaonline.it/penale”. Acesso em 22 de setembro de 208.

JARDIM, Afrânio Silva. Direito Processual Penal. 11 a ed.. Rio de Janeiro: Forense, 2002.

LAI, Ivano. "Le investigazioni difensive nei reati di criminalità organizzata" in La Giustizia Penale 2003 (parte terza: Procedura Penale), pp. 122/28.

LOPES JR., Aury. Sistemas de investigação preliminar no Processo Penal. $3^{\mathrm{a}}$ ed.. Rio de Janeiro: Lumen Juris, 2005.

Direito Processual Penal e sua conformidade constitucional. $3^{\text {a }}$ ed.. Rio de Janeiro: Lumen Juris, 2008, vol. I.

- "A opacidade da discussão em torno do promotor investigador (mudem os inquisidores, mas a fogueira continuará acesa)” in Boletim do Instituto Brasileiro de Ciências Criminais, n. ${ }^{\circ}$ 142, setembro/2004, pp. 10/11.

- "Direito de defesa e acesso do advogado aos autos do inquérito policial: uma (des)construção jurisprudencial” in Revista Brasileira de Ciências Criminais, n. ${ }^{0}$ 43, abr./jun. de 2003, pp. 378/96.

. ("Bom para quê(m)?) in Boletim do Instituto Brasileiro de Ciências Criminais, n. ${ }^{\circ}$ 188, julho/2008, pp. 09/11.

MARQUES, José Frederico. Elementos de Direito Processual Penal. Campinas: Bookseller, 1997, vol. I.

MEHMERI, Adilson. Inquérito Policial (dinâmica). São Paulo: Saraiva, 1992. 
MELlADO, José María Ascencio. Principio Acusatorio y Derecho de Defensa en el Proceso Penal. Madri: Trivium, 1991.

MENDES DE ALMEIDA Jr., João. O processo criminal brasileiro. $4^{\text {a }}$ ed.. Rio de Janeiro: Freitas Bastos, 1959, vol. I.

MIRABETE, Julio Fabbrini. Processo Penal. 5a ed.. São Paulo: Atlas, 1996.

MORAES, Bismael B.. Direito e Polícia (uma introdução à Polícia Judiciária). São Paulo: Revista dos Tribunais, 1986.

. “O inquérito policial é o vilão no Direito brasileiro?” in Revista Brasileira de Ciências Criminais, n. ${ }^{\circ}$ 28, out./dez. 1999, pp. 255/64.

MOURA, Maria Thereza Rocha de Assis. A prova por indícios no processo penal. São Paulo: Saraiva, 1994.

MOURA, Maria Thereza Rocha de Assis e PITOMBO, Cleunice A. Valentim Bastos. “Defesa Penal: Direito ou Garantia” in Revista Brasileira de Ciências Criminais, n. 04, out./dez. de 1993, pp. 110/25.

MURRU, Costantino. "Sulle indagini difensive”. Disponível na internet: “www.penale.it”. Acesso em 14 de setembro de 2008.

NOBILI, Massimo. “Giusto processo e indagini difensive: verso una nuova procedura penale?” in Il Diritto e La Differenza - scritti in onore di Alessandro Baratta, a cura di GIORGI, Raffaele De. Lecce: Pensa Multimedia, 2002, pp. 478/98.

NOCETTI, Alessandro. “Indagini difensive, parità sostanziale o finzione normativa?”. Disponível na internet: “www.criminologia.it/diritto”. Acesso em 14 de setembro de 2008.

NORONHA, Edgard Magalhães. Curso de Direito Processual Penal. 28 a ed.. São Paulo: Saraiva, 1998.

NOTARO, Gianfranco. "Il nuovo regime delle indagini difensive: riflessioni a prima lettura”. Disponível na internet: “www.penale.it”. Acesso em 22 de setembro de 2008. 
NUCCI, Guilherme de Souza. Código de Processo Penal Comentado. $8^{\text {a }}$ ed.. São Paulo: Revista dos Tribunais, 2008.

OLIVEIRA, Francisco da Costa. A Defesa e a Investigação do Crime. Coimbra: Livraria Almedina, 2004.

PEDROSO, Fernando de Almeida. Processo Penal. O direito de defesa: repercussão, amplitude e limites. $3^{\text {a }}$ ed.. São Paulo: Revista dos Tribunais, 2001.

PISANELLI, Lucia Iandolo. “Indagini preliminari delegate” in Rivista Italiana di Diritto e Procedura Penale, vol. 38, 1995, pp. 1161/76.

PITOMBO, Cleunice Valentim Bastos. “Considerações iniciais sobre a Lei 11.690/08 in Boletim do Instituto Brasileiro de Ciências Criminais, n. ${ }^{\circ}$ 188, julho/2008, pp. 20/22.

PITOMBO, Sérgio Marcos de Moraes. Inquérito policial: novas tendências. Belém: CEJUP, 1987.

. "Breves notas sobre o anteprojeto de Lei, que objetiva modificar o Código de Processo Penal, no atinente à investigação policial” in Estudos Criminais em Homenagem a Evandro Lins e Silva (Criminalista do Século). São Paulo: Método, 2001, pp. 337/51. “O indiciamento como ato de Polícia Judiciária” in Revista dos Tribunais, n. ${ }^{\circ}$ 577, novembro de 1983, pp. 313/16.

. "Inquérito policial: exercício do direito de defesa" in Boletim do Instituto Brasileiro de Ciências Criminais, n. ${ }^{0}$ 83, edição especial, outubro/1999, p. 14.

PONTES DE MIRANDA, João Francisco. Comentários à Constituição de 1967. São Paulo: Revista dos Tribunais, 1967, t. V.

PRADO, Geraldo. Sistema Acusatório. Rio de Janeiro: Lumen Juris, 1999.

RAMOS, João Gualberto Garcez. Curso de Processo Penal norte-americano. São Paulo: Revista dos Tribunais, 2006.

RICCIO, Giuseppe. "Profili funzionali e aspetti strutturali delle indagini preliminari” in Rivista Italiana di Diritto e Procedura Penale, vol. 33, 1990, pp. 95/112. 
ROSSI, Gianluca. “Indagini difensive: luci ed ombre della norma vigente”. Disponível na internet: “www.giuffrereggioemilia.it/main/indaginidifensive”. Acesso em 25 de outubro de 2008.

ROXIN, Claus. Pasado, presente y futuro del derecho procesal penal. Santa Fe: Rubinzal Culzoni, 2007.

RUGGIERO, Giuseppe. Compendio delle investigazioni difensive. Milano: Giuffrè, 2003.

SAAD, Marta. O direito de defesa no inquérito policial. São Paulo: Revista dos Tribunais, 2004.

As medidas assecuratórias do Código de Processo Penal como forma de tutela cautelar destinada à reparação do dano causado pelo delito. Tese de doutorado defendida perante a Faculdade de Direito da Universidade de São Paulo em 04 de maio de 2007.

SANTOS, Leandro Galluzzi dos. "Procedimentos - Lei 11.719, de 20.06.2008” in As reformas no Processo Penal: as novas Leis de 2008 e os projetos de reforma. MOURA, Maria Thereza Rocha de Assis (org.). São Paulo: Revista dos Tribunais, 2008, pp. 298/344.

SCARANCE FERNANDES, Antonio. Processo Penal Constitucional. $3^{\mathrm{a}}$ ed.. São Paulo: Revista dos Tribunais, 2002.

. Reação defensiva à imputação. São Paulo: Revista dos Tribunais, 2002.

. Teoria Geral do Procedimento e o Procedimento no Processo Penal. São Paulo: Revista dos Tribunais, 2005.

. O papel da vítima no processo criminal. São Paulo: Malheiros, 1995.

. "Rumos da investigação no direito brasileiro" in Boletim do Instituto Manoel Pedro Pimentel, n. ${ }^{\circ}$ 21, jul./set. 2002, pp. 12/13.

. "Reflexões sobre as noções de eficiência e de garantismo no Processo Penal” in Sigilo no Processo Penal: eficiência e garantismo. SCARANCE FERNANDES, Antonio; ALMEIDA, José Raul Gavião de e MORAES, Maurício Zanoide de (orgs.). São Paulo: Revista dos Tribunais, 2008, pp. 09/28. 
SCHOLZ, Leônidas Ribeiro. "Sistemas Processuais Penais e Processo Penal Brasileiro” in Revista dos Tribunais, n. ${ }^{\circ}$ 764, junho de 1999, p. 459/68.

SCORZA, Franco e SCORZA, Paola. L'Attivitá Investigativa del Difensore nel Giusto Processo. Piacenza: La Tribuna, 2003.

SILVA, De Plácido e. Vocabulário Jurídico. 15ª ed.. Rio de Janeiro: Forense, 1998.

SILVA, José Afonso da. Curso de Direito Constitucional Positivo. 14 ${ }^{\text {a }}$ ed.. São Paulo: Malheiros, 1997.

SILVA, Ivan Luís Marques da. Reforma Processual Penal de 2008. São Paulo: Revista dos Tribunais, 2008.

SIRACUSANO, Delfino; TRANCHINA, Giovanni e ZAPPALÀ, Enzo. Elementi di diritto processuale penale. $3^{\mathrm{a}}$ ed.. Milano: Giuffrè, 2007.

SOARES, Guido Fernando Silva. "Estudos de Direito Comparado: o que é a 'Common Law', em particular, a dos EUA” in Revista da Faculdade de Direito da Universidade de São Paulo, v. 92, 1997, pp. 163/98.

SOUZA, Carlos Laet de. “Da investigação policial e da instrução criminal provisória” in

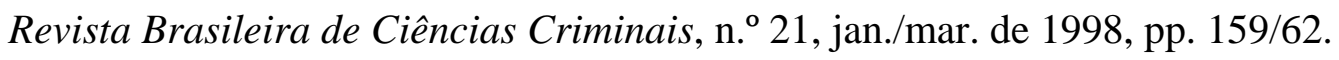

SOUZA, José Barcelos de. Teoria e prática da ação penal. São Paulo: Saraiva, 1979. . A defesa na Polícia e em Juízo. 2a ed.. São Paulo: Sugestões Literárias, 1973. "Poderes da defesa na investigação e investigação pela defesa”, notas referentes à palestra proferida no “IV Jornadas Brasileiras de Direito Processual Penal”, realizado no município do Guarujá/SP, nos dias 06 a 09 de novembro de 2004. Disponível na internet: “www.iamg.org.br”. Acesso em 03 de março de 2008.

STEFANI, Eraldo. Codice dell'indagine difensiva penale - commentato ed annotato con la giurisprudenza e la deontologia. Milano: Giuffrè, 2005.

SUANNES, Adauto. Os fundamentos éticos do devido processo penal. $2^{\mathrm{a}}$ ed.. São Paulo: Revista dos Tribunais, 2004. 
SUÁREZ-BÁRCENA, Emilio de Llera. El modelo constitucional de investigación penal. Valencia: Tirant lo blanch, 2001.

TAORMINA, Carlo. Il regime della prova nel Processo Penale. Torino: G. Giappichelli Editore, 2007.

TONINI, Paolo. Manuale di Procedura Penale. 8ª ed.. Milano: Giuffrè, 2007.

- "Direito de defesa e prova científica: novas tendências do processo penal italiano” in Revista Brasileira de Ciências Criminais, n. ${ }^{\circ}$ 48, mai./jun. de 2004, pp. $194 / 214$.

TORNAGHI, Hélio. Curso de Processo Penal. $9^{a}$ ed.. São Paulo: Saraiva, 1995, vol. 1.

TOURINHO FILHO, Fernando da Costa. Manual de Processo Penal. 11 ${ }^{\mathrm{a}}$ ed.. São Paulo: Saraiva, 2009.

Comentários à Lei dos Juizados Especiais Criminais. 4a ed.. São Paulo: Saraiva, 2007.

TOVO, Paulo Cláudio. "O inquérito policial em sua verdadeira dimensão” in Estudos de Direito Processual Penal. TOVO, Paulo Cláudio (org.). Porto Alegre: Livraria do Advogado, 1995, pp. 147/51.

TRIGGIANI, Nicola. Le investigazioni difensive. Milano: Giuffrè, 2002.

TUCCI, Rogério Lauria. Persecução penal, prisão e liberdade. São Paulo: Saraiva, 1980. Direitos e garantias individuais no Processo Penal brasileiro. São Paulo: Saraiva, 1993.

Teoria do Direito Processual Penal: jurisdição, ação e processo penal (estudo sistemático). São Paulo: Revista dos Tribunais, 2002.

. Lineamentos do processo penal romano. São Paulo: José Bushatsky, 1976.

Ministério Público e investigação criminal. São Paulo: Revista dos Tribunais, 2004. 
. “Indiciamento e Qualificação Indireta” in Revista dos Tribunais, n. ${ }^{0}$ 571, maio de 1983, pp. 291/94.

VENTURA, Pasquale. Le indagini difensive. Milano: Giuffrè, 2005.

VIDAL, Luís Fernando Camargo de Barros. "Inquisitividade e Eficácia do Inquérito Policial” in Justiça \& Democracia, n. ${ }^{\circ}$ 04, pp. 291/97.

VOGLER, Richard. "Justiça consensual e processo penal” in Processo Penal e Estado de Direito. CHOUKR, Fauzi Hassan e AMBOS, Kai (orgs.). Campinas: Edicamp, 2002, pp. 283/307.

ZILLI, Marcos Alexandre Coelho. A iniciativa instrutória do juiz no Processo Penal. São Paulo: Revista dos Tribunais, 2003.

— . "O Pomar e as Pragas” in Boletim do Instituto Brasileiro de Ciências Criminais, n. ${ }^{\circ}$ 188, julho/2008, pp. 02/03.

. “Os bons ventos de Haia” in Boletim do Instituto Brasileiro de Ciências Criminais, n. ${ }^{\circ} 190$, setembro/2008, pp. $13 / 14$.

.Hamlet entre nós” in Boletim do Instituto Brasileiro de Ciências Criminais, n. ${ }^{\circ}$ 192, novembro/2008, pp. 06/07. 


\section{RESUMO/ABSTRACT}

O objeto primordial desta dissertação é conceituar a investigação criminal defensiva, sob a ótica da eficiência e do garantismo, e demonstrar a necessidade deste instituto nos ordenamentos jurídicos em que a investigação pública é tendencialmente acusatória.

Para tanto, nos dois capítulos iniciais, esclarecem-se alguns aspectos gerais condizentes ao tema em análise, a saber: a definição de investigação criminal e suas principais características; a questão da parcialidade do Ministério Público e a investigação do crime por este órgão; e a definição de inquérito policial e sua disciplina legal no Brasil.

Em seguida, aborda-se a relação da investigação defensiva com os princípios constitucionais da igualdade e da ampla defesa, que se encontram na base de um processo penal acusatório e asseguram às partes igual oportunidade de comprovarem os seus argumentos. Por conta disso, se um sistema jurídico prescreve a investigação do crime pelo próprio órgão acusatório, é de rigor que o imputado tenha direito equivalente, sob pena de se violar os mencionados direitos fundamentais.

Ademais, a investigação defensiva, ao permitir a obtenção de elementos que serão contrapostos à investigação pública, amplia o campo cognitivo do Magistrado, o qual disporá de um maior número de dados materiais para fundamentar decisão acerca da viabilidade da acusação e da adoção de medidas cautelares.

Após a análise constitucional da investigação defensiva, estuda-se o tratamento conferido pelo Direito estrangeiro a esta matéria, particularmente na Itália, onde o tema está em voga e é objeto de importantes e auspiciosos debates jurídicos.

Ao final, a dissertação cuida da concretização da investigação defensiva, isto é, o modo como deve se desenvolver, as suas limitações, a utilização do seu resultado e a possibilidade de inserção no ordenamento jurídico pátrio. 
The main subject of this dissertation is to create a concept of the criminal defense investigation, under the efficiency and the guarantism perspectives, and to demonstrate the need of such institute in the legal system in which the public investigation has an acusatory tendency.

For this purpose, in the first two chapters, the dissertation clarifies certain general aspects regarding the subject under analysis, such as: the definition of criminal investigation and its main characteristics; the question of partiality of the Public Prosecutor's Office and the criminal investigation ran by this office; and the definition of criminal investigation and its legal regulation in Brazil.

Following, the dissertation approachs the relation of defensive investigation with the constitutional principles of equality and of full defense, which are in the base of an accusatory criminal procedure and assure the parties equal opportunities to prove their arguments. For this reason, if a legal system provides for a criminal investigation to be conducted by the accusatory party itself, it is imperative that the accused has equivalent rights, otherwise the legal system will be violating the above mentioned fundamental rights.

Furthermore, in allowing gathering elements which shall be confronted with the official investigation, the defense investigation expands the cognitive field of the Magistrate, who will have more material data to pronounce a decision regarding the accusation's viability and the adoption of cautionary measures.

After the constitutional analysis of the defense investigation, the dissertation enters into the foreign law on this subject, particularly from Italy, where the matter is highly in evidence and is the subject of important and auspicious legal debates.

In the end, the dissertation provides for the materialization of the defense investigation, i.e., the manner in which it shall be developed, its limitations, the use of its results and the possible insert in our national legal ordinance. 